
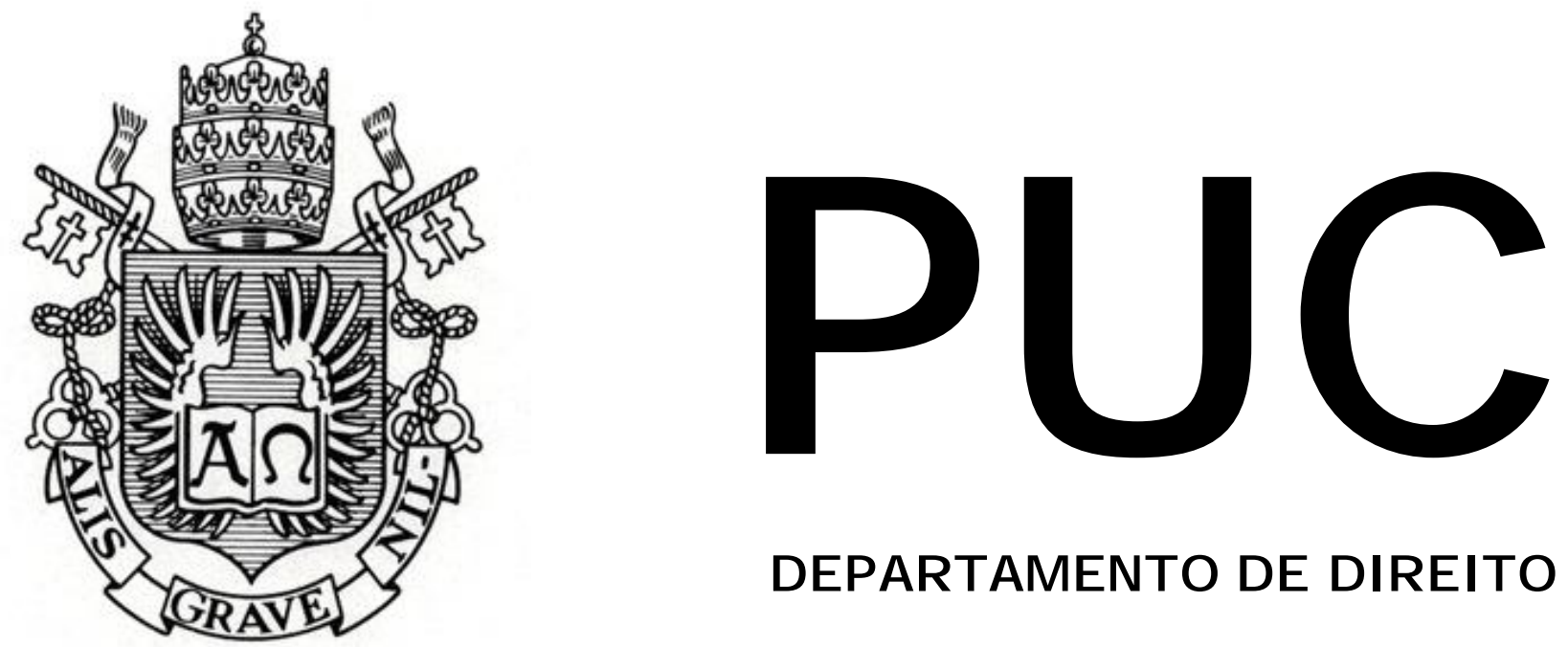

DEPARTAMENTO DE DIREITO

A administração de companhias e a business judgment rule: uma análise à luz do direito brasileiro

por

Pedro Henrique Castello Brigagão

ORIENTADOR: Julian Fonseca Peña Chediak

2014.1

PONTIFÍCIA UNIVERSIDADE CATÓLICA DO RIO DE JANEIRO

RUA MARQUÊS DE SÃO VICENTE, 225 - CEP 22453-900

RIO DE JANEIRO - BRASIL 


\title{
A administração de companhias e a business judgment rule: uma análise à luz do direito brasileiro
}

\author{
por \\ Pedro Henrique Castello Brigagão
}

Monografia apresentada ao Departamento de Direito da Pontifícia Universidade Católica do Rio de Janeiro (PUC-Rio) para a obtenção do Título de Bacharel em Direito.

Orientador: Julian Fonseca Peña Chediak

2014.1 


\section{AGRADECIMENTOS}

Seria injusto encerrar este ciclo de cinco anos da graduação em Direito sem deixar registrado, mesmo que de forma breve, o meu agradecimento àqueles sem os quais esse período não teria sido o mesmo.

Em primeiro lugar, agradeço àqueles sem os quais nada disso seria

possível. Àqueles que mais contribuem para o meu sucesso pessoal e profissional, que mais me incentivam, que mais me apoiam e que estão sempre ao meu lado: Gustavo Brigagão e Carla Castello, meus amados pais. Agradeço por tudo, sem temer a amplitude que essa palavra possa ter.

Agradeço à minha avó Flavita Castello, pessoa especial cuja simples companhia torna meus dias muito mais agradáveis, com a ressalva de que qualquer agradecimento é insuficiente para representar toda a sua importância em minha vida.

À minha tia e madrinha Mariana Castello, pessoa única com o dom de unir pessoas, de alegria constante e contagiante, por todo o carinho e conselhos, pessoais e profissionais.

À minha linda namorada Rafaela Emery, por todo o amor, companheirismo, compreensão e carinho. Não há momento ruim que o seu sorriso não possa curar. Não poderia deixar de agradecer, ainda, por todas as suas revisões, que muito contribuíram para melhorar a qualidade deste trabalho.

A todos os meus amigos do Chediak Advogados, em especial Carla Dau, Fernanda Mitsuya, Luiz Felipe Cordeiro e Carolina Becman, só tenho a agradecer por todo o aprendizado e a agradável convivência, que torna os dias de trabalho muito mais leves.

Aos meus amigos da PUC-Rio, André Jahara, André Tosta, Gabriel Carvalho, Lis Aguileira e Marília Lopes, agradeço por toda a companhia e 
suporte nesses últimos cinco anos. Representam, sem sombra de dúvidas, amizades raras que durarão para o resto da vida.

Aos meus amigos da Escola Parque, cuja amizade se mantém forte, obrigado por todo o apoio e presença em todos esses cinco anos.

À Professora Norma Parente, só tenho a agradecer por ter sempre acreditado em meu potencial e me concedido preciosas oportunidades de aprendizado, tais como os PIBICs finalizados em 2012 e em 2013 e o grupo de estudos do IBGC, experiências que levarei para o resto da vida e que são, em grande parte, responsáveis por despertar o meu interesse no estudo da business judgment rule.

Por fim, mas não menos importante, agradeço ao Julian Chediak, seja como meu professor de direito societário e mercado de capitais, seja como meu orientador no programa de monitoria, seja como meu chefe, seja como orientador desta monografia. Com a consciência de que pouquíssimos terão a mesma oportunidade, agradeço por toda confiança, aprendizado e incentivo, que contribuem em muito para o meu desenvolvimento pessoal e profissional. 


\section{Resumo}

Brigagão, Pedro Henrique Castello. A administração de companhias e a business judgment rule: uma análise à luz do direito brasileiro. 191 p. Monografia (Graduação em Direito) - Pontifícia Universidade Católica do Rio de Janeiro: Rio de Janeiro, 2014.

O presente trabalho tem como primeiro objetivo promover uma análise de como se dá administração de companhias e a prática da tomada de decisão de administradores, considerando-se os principais fatores que influenciam a atuação de diretores e conselheiros. Esta monografia também estudará o regime de responsabilização do direito brasileiro e a business judgment rule, de forma a possibilitar um exame crítico da compatibilidade entre as normas jurídicas e a realidade atinente à tomada de decisão. Adicionalmente, verificar-se-á como se dá a recepção da regra norte-americana no direito brasileiro, decompondo-se o entendimento majoritário e sugerindo-se uma nova visão a respeito do assunto. Por fim, serão apresentados e analisados os casos julgados pela Comissão de Valores Mobiliários que se relacionam com o tema, bem como dois processos julgados pelo Poder Judiciário, nos quais se mostrou preocupante a atuação dos magistrados brasileiros.

Palavras Chave: Direito Societário - Mercado de Capitais - Business Judgment Rule - Administradores - Sociedade Anônima - Responsabilidade Civil - Ato Regular de Gestão - Companhia - Poder Judiciário - Dever de Diligência Tomada de Decisão - Comissão de Valores Mobiliários. 


\section{SUMÁRIO}

INTRODUÇÃ

CAPÍTULO 1 - A ADMINISTRAÇÃO DAS SOCIEDADES ANÔNIMAS

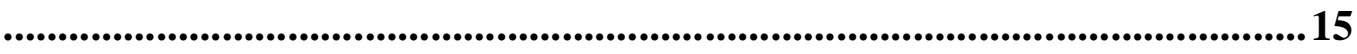

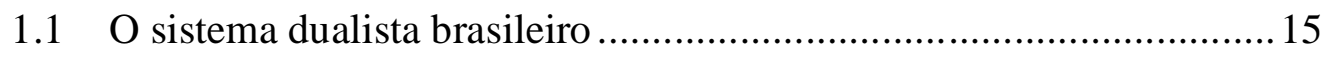

1.1.1 O conselho de administração ………………………………..... 17

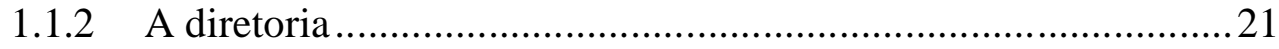

1.2 Administração disjunta, conjunta e colegial......................................2 23

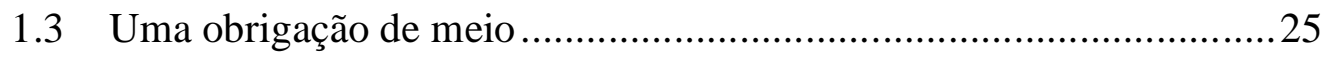

1.4 O dever de diligência e seus aspectos .............................................2

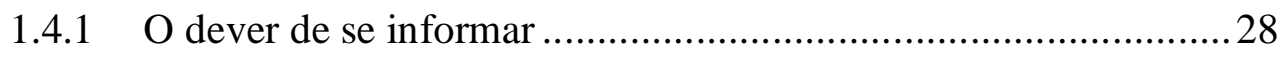

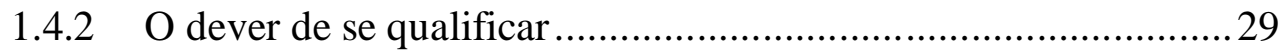

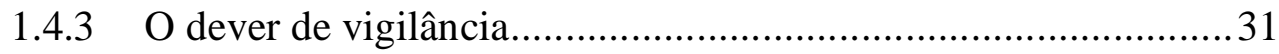

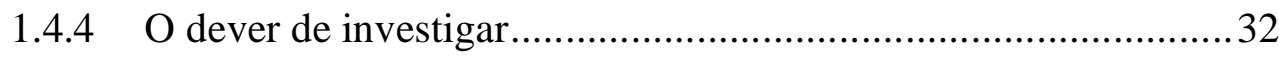

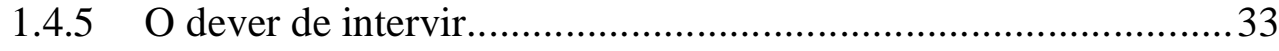

CAPÍTULO 2 - A TOMADA DE DECISÃO .................................................35

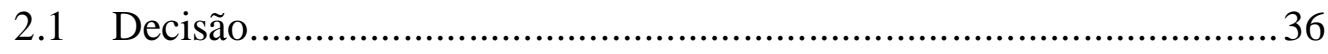

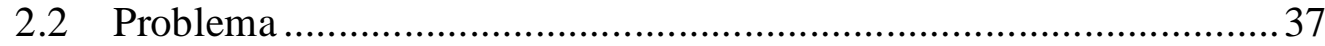

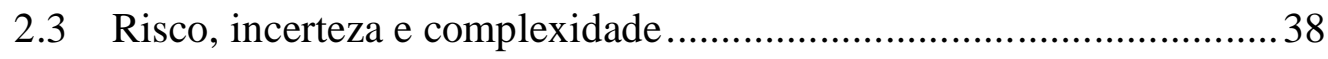

2.4 A relação necessária entre risco, incerteza e lucro.................................43



2.5.1 O conceito de jogo e o objetivo da Teoria dos Jogos....................51

2.5.2 O dilema do prisioneiro: a estratégia dominante nem sempre leva

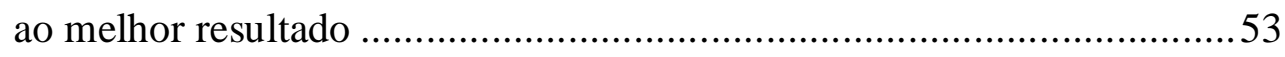

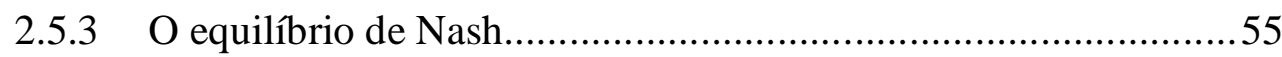

CAPÍTULO 3 - O REGIME DE RESPONSABILIDADE DOS ADMINISTRADORES DE SOCIEDADES ANÔNIMAS NO DIREITO

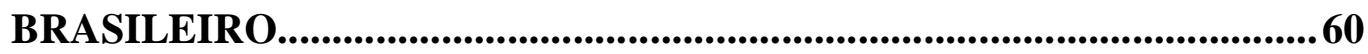

3.1 Da irresponsabilidade dos administradores por atos próprios ...............64 
3.1.1 Prática de ato regular de gestão em nome da sociedade

64

3.1.2 Aprovação das contas e demonstrações financeiras pela assembleia geral ordinária

3.1.3 Cumprimento de deliberações lícitas de órgãos hierarquicamente superiores 73

3.1.4 Exclusão de responsabilidade pelo juiz..................................76

3.2 Da responsabilidade dos administradores.................................... 79

3.2.1 Atos praticados com culpa ou dolo ....................................... 80

3.2.1.1 Responsabilidade objetiva ........................................... 82

3.2.1.2 Equivalência entre as hipóteses - responsabilidade subjetiva .. 84

3.2.1.3 Inversão do ônus da prova.............................................. 86

3.2.2 Responsabilidade individual e solidária ..................................89

3.3 Responsabilidade da companhia por ato do administrador ............... 92

CAPÍTULO 4 - A BUSINESS JUDGMENT RULE .................................95

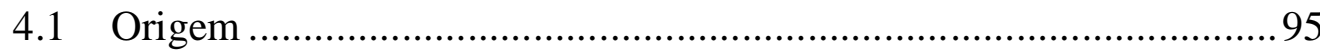

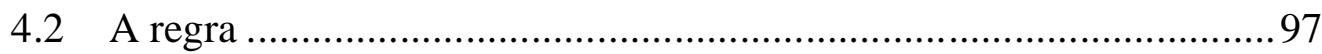

4.2.1 A presunção ................................................................. 97

4.2.2 A não proteção de decisões irracionais .................................. 98

4.2.3 Os elementos da regra ................................................ 100

4.2.3.1 Ocorrência de uma decisão negocial............................... 100

4.2.3.2 Desinteresse e independência ....................................... 102

4.2.3.3 Diligência................................................................ 104

4.2.3.3.1 Mas quanta informação é necessária?........................ 106

4.2.3.4 Boa-fé .......................................................................... 109

4.2.3.5 Inexistência de abuso de discricionariedade, um quinto elemento?

4.2.4 Tentativas de codificação ................................................. 113

4.2.4.1 O Model Business Corporation Act............................... 113

4.2.4.2 Principles of Corporate Governance: Analysis and

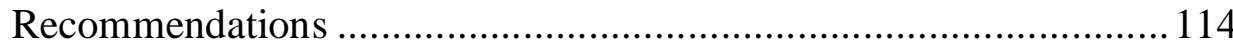

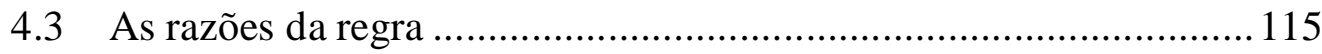


4.3.1 A imputação de responsabilidade por erros honestamente cometidos afastaria profissionais competentes da administração de companhas. 117

4.3.2 Administradores devem ser encorajados a tomar riscos ............. 118

4.3.3 Juízes não são administradores 122

4.3.4 Companhias são geridas por administradores, e não por acionistas 124

4.3.5 Acionistas podem desconstituir e substituir os administradores 126 CAPÍtUlO 5 - A BUSINESS JUDGMENT RULE NO DIREITO

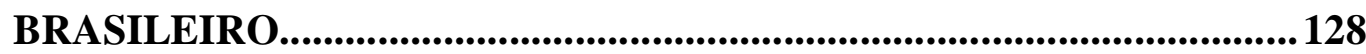

5.1 A recepção da regra pela Lei das S.A............................................. 128 5.1.1 O entendimento majoritário: a business judgment rule e o $\S 6^{\circ}$ do artigo 159 128

5.1.2 Uma nova sugestão: a business judgment rule e o ato regular de gestão 137

5.2 A aplicação da business judgment rule pela CVM 144

5.3 A aplicação da business judgment rule pelo Poder Judiciário brasileiro 156

5.3.1. Apelação Cível no 7.460/04 - “O 'investimento' (...) foi, na realidade, catastrófico, pois são remotas as possibilidades de retorno do vultuoso capital investido". 157

5.3.2 Processo n 2003.001.047338-0 - “A emissão pública das ações não

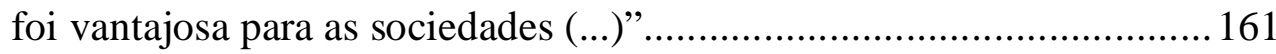

5.4 A business judgment rule e a crise dos subprime .............................. 166

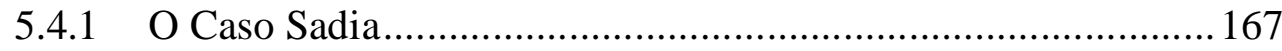

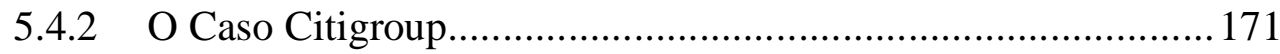

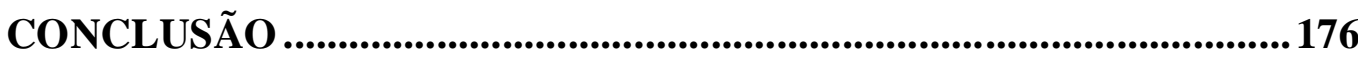

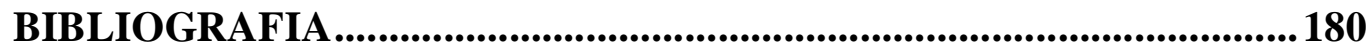




\section{INTRODUÇÃO}

A tomada de riscos é essencial a qualquer atividade empresarial. Sem risco, não há lucro. O fato de ser o futuro imprevisível faz com que recursos sejam aplicados em negócios cujos retornos são desconhecidos. Um investimento pode resultar em um sucesso incontestável, com altíssimos lucros, mas os prejuízos também são possíveis e, muitas vezes, prováveis em todos os negócios.

O tema ganha maior relevância no caso das sociedades anônimas, em primeiro por conta da sua importância no cenário econômico e, em segundo, por causa do fenômeno da cisão entre propriedade e gestão nessas pessoas jurídicas.

Isto é, a partir do momento em que essas sociedades são capazes de reunir grandes montantes de recursos e atingir um alto número de investidores principalmente se consideradas as companhias abertas - e que a sua gestão se dá por pessoa que não os seus sócios, a tomada de riscos se mostra uma questão um tanto quanto delicada.

Em paralelo, é importante que se leve em conta que, ao se reunirem e constituírem uma sociedade anônima, o principal interesse dos acionistas é auferir lucros. Para isso, centralizam o poder decisório da companhia em administradores por eles eleitos, que, por meio do exercício do objeto social, terão como principal função buscar distribuir o máximo de dividendos possível.

Sendo assim, acionistas esperam dos administradores que tomem riscos, busquem a inovação, arquitetem grandes projetos, aumentem a participação da companhia no mercado etc. Ou seja, esperam que seus investimentos lhes rendam os frutos desejados.

O sucesso, contudo, nem sempre é possível. E, quando uma decisão arriscada resulta em prejuízos, é natural que os prejudicados procurem um culpado para fazer de alvo e dele tentarem reaver o que foi perdido. Acionistas, juízes e até mesmo a sociedade em geral, analisando a atuação do administrador, 
geralmente formulam diferentes concepções a respeito do que ele deveria ter feito e não fez.

Mas é muito fácil olhar para trás, sem a necessidade de tomar uma decisão da forma mais rápida possível, com todas as informações disponíveis, conhecendo os resultados de todas as alternativas, e condenar a conduta do administrador que trouxe prejuízos para a companhia.

Nesse contexto, a business judgment rule ganha enorme relevância, principalmente no Brasil, país emergente com grande potencial de crescimento, mas que aloca pouquíssimos recursos em inovação, como mostram indicadores do Ministério da Ciência, Tecnologia e Inovação ${ }^{1}$.

Originada em tribunais ingleses e norte-americanos no século XVIII e desenvolvida principalmente no estado de Delaware, a regra veda a revisão, por parte do Poder Judiciário (e, indiretamente, por parte também dos acionistas), de decisões negociais tomadas por administradores de boa-fé, diligentemente e no interesse da companhia.

Para isso, leva em consideração que (i) administradores competentes deixariam de aceitar o cargo se pudessem ser responsabilizados pela simples infelicidade de uma decisão negocial; (ii) faz parte da essência da administração de empresas tomar riscos; (iii) juízes não são experts da ciência de administração de empresas; (iv) a administração de companhias é conferida a administradores, e não aos acionistas; e (v) se desejarem, os acionistas podem destituir e substituir administradores que tomem decisões insatisfatórias, sendo excessivo buscar deles qualquer reparação no Judiciário.

\footnotetext{
${ }^{1}$ Em 2011, os gastos do país com pesquisa e desenvolvimento equivaliam a somente 1,21\% do Produto Interno Bruto - PIB, ao passo que Coréia do Sul, Japão, Alemanha e Estados Unidos, por exemplo, investiram, respectivamente, 4,03\%, 3,39\%, 2,88\% e 2,77\%. Dados disponíveis em <http://www.mct.gov.br/index.php/content/view/336625/Dispendios_nacionais_em_pesquisa_e_desen volvimento_P_D_em_relacao_ao_produto_interno_bruto_PIB_de_paises_selecionados.html $>$. Acesso em 26 abr. 2014.
} 
Assim, reconhecendo a importância do tema no cenário jurídicoeconômico do país, o presente trabalho conta com três objetivos.

Sem uma ordem de relevância, o primeiro objetivo é analisar como se estrutura a administração de uma sociedade anônima e quais são os principais elementos da prática da tomada de decisão por parte dos administradores, estudando-se como se dá o processo decisório, quais dificuldades lhes são inerentes e porque o risco e a incerteza são fatores essenciais ao lucro.

Verifica-se, com isso, qual o ponto de partida do legislador - ou dos tribunais, no caso da common law - ao elaborar o regime jurídico de responsabilização dos administradores de companhias, o que inclui a business judgment rule.

O segundo objetivo é descrever o conceito dessa regra, tal como elaborado pelos tribunais norte-americanos, de forma que se possa constatar a sua plena compatibilidade com a estrutura da administração de companhias e a prática da tomada de decisão. Afinal, como ensina MAXIMILIANO, "é tarefa primordial do executor [do Direito] a pesquisa da relação entre o texto abstrato e o caso concreto, entre a norma jurídica e o fato social"².

O terceiro objetivo, por fim, é demonstrar que a business judgment rule é compatível com o direito brasileiro e destacar como ela - ou ao menos os seus princípios - vem sendo abordada pela CVM e pelo Poder Judiciário brasileiro.

Para isso, esta monografia se estruturará em duas partes, num total de cinco capítulos.

A primeira parte abrange os Capítulos 1 e 2 e terá como foco a análise da administração de companhias.

O Capítulo 1 descreverá como se dá a administração das sociedades anônimas de acordo com a Lei $\mathrm{n}^{\circ}$ 6.404, de 15 de dezembro de 1976, a ser aqui

\footnotetext{
${ }^{2}$ MAXIMILIANO, Carlos. Hermenêutica e Aplicação do Direito. Rio de Janeiro: Forense, 1994. p. 1.
} 
designada como "Lei das S.A.”. Serão analisados, principalmente, os órgãos da administração que compõem o sistema dualista brasileiro, o processo decisório a eles inerente, a natureza da obrigação do administrador e o seu principal dever fiduciário ${ }^{3}$, base de todos os demais: o dever de diligência.

Por meio desse primeiro Capítulo, busca-se consolidar os principais aspectos da estrutura da administração das sociedades anônimas tal como previsto pela Lei das S.A. Com isso, permitir-se-á distinguir as funções de diretores e conselheiros, bem como qual o tipo de decisão mais comumente tomado por uns e por outros, bem como constatar que a obrigação desses administradores é de meio, estando eles obrigados a observar o dever de diligência, mas não a alcançar determinado resultado.

Acredita-se que, com isso, o exame da compatibilidade entre a business judgment rule e a realidade da administração de companhias será favorecido.

Em seguida, o Capítulo 2 procurará demonstrar, de forma breve, os fatores e dificuldades que influenciam a tomada de decisão de um administrador de sociedade empresária. Os conceitos de problema, risco, incerteza e complexidade, elementos básicos que influenciam toda decisão, serão estudados.

No Capítulo 2, buscar-se-á, também, fundamentar a máxima de que, sem risco, não há lucro, cada vez mais repetida em obras jurídicas, mas sempre desacompanhada de uma fundamentação lógica.

\footnotetext{
${ }^{3}$ Sobre o termo dever fiduciário, é importante que se faça uma ressalva: apesar de amplamente utilizado pela doutrina, aplicadores do Direito e inclusive por esta monografia, tal termo não é considerado por alguns a maneira mais adequada para se referir aos deveres de diligência, lealdade e obediência ao interesse social impostos aos administradores pela Lei das S.A. Segundo TAVARES GUERREIRO, a partir do momento em que esses deveres são impostos pela lei, eles são cumpridos não em razão da fidúcia existente entre o administrador, a companhia e os acionistas, mas justamente em razão de serem uma imposição legal. O uso equivocado do termo dever fiduciário, explica o autor, advém da tradução da expressão fiduciary duty dos sistemas anglo-saxões. Nesse sentido, TAVARES GUERREIRO utiliza a expressão dever legal no lugar de dever fiduciário (TAVARES GUERREIRO, José Alexandre. Propriedade Fiduciária das Ações. In: LOBO, Jorge (Org.). Reforma da Lei das Sociedades Anônimas: Inovações e Questões Controvertidas da Lei ${ }^{\circ}$ 10.303, de 31.10.2001. Rio de Janeiro: Forense, 2002. p. 53-54).
} 
Ainda nesse Capítulo, a Teoria dos Jogos será superficialmente abordada, de modo que se possa descrever a atuação de administradores em um mercado competitivo, deixando patente, assim, as dificuldades pelas quais esses profissionais passam para obter algum sucesso em uma economia de mercado. O objetivo desse ponto se dá em demonstrar que, mesmo tendo estudado, refletido, se informado, enfim, tomado todas as cautelas possíveis para que a sua decisão negocial dê certo, o administrador pode ver todo o seu planejamento dar errado por conta da atuação de seus concorrentes.

Tentar-se-á destacar, aqui, que o negócio de uma companhia está sujeito a inúmeros fatores que podem prejudicá-lo, sendo a culpa do administrador apenas um deles (e não o único), o que, juntamente com o fato de que administradores devem necessariamente tomar riscos, deve ser sempre considerado por juízes quando da aplicação da norma jurídica ao caso concreto.

A primeira parte deste trabalho, então, procurará descrever como se dá a administração de uma companhia para que, ao final, seja possível analisar a relação entre a business judgment rule e o fato social por ela regulado: a tomada de decisão.

A segunda parte, composta pelos Capítulos 3, 4 e 5, tem como foco a análise do ordenamento jurídico no que se refere ao regime de responsabilidade dos administradores de sociedades anônimas.

O Capítulo 3, assim, exporá o regime de responsabilidade dos administradores de sociedades anônimas no direito brasileiro, de forma a demonstrar em quais hipóteses o administrador será ou não responsável por seus atos. Com os estudos a serem trazidos pelos capítulos anteriores, tornar-se-á possível verificar em que medida esse regime se comunica com a estrutura da administração e a prática da tomada de decisão. Além disso, preparar-se-á o leitor para uma análise de compatibilidade entre o ordenamento jurídico nacional e a business judgment rule, a ser abordada no capítulo seguinte. 
O Capítulo 4, nesse sentido, abordará a regra norte-americana, expondo sua origem, principais características, elementos e razões. Com isso, será possível averiguar se a business judgment rule é compatível com a prática da tomada de decisão e quais os seus benefícios à saúde econômica de um país.

Finalmente, o Capítulo 5 estudará a recepção da business judgment rule pela Lei das S.A. e como os julgadores brasileiros vêm aplicando a regra nos casos concretos. Para isso, em primeiro, expor-se-á como a maior parte da doutrina nacional entende ter sido a regra prevista pela mencionada lei. Em seguida, uma nova sugestão será apresentada, demonstrando-se a plena compatibilidade desse instituto com o conceito de ato regular de gestão.

Depois disso, será analisada a aplicação da business judgment rule pela CVM nos processos administrativos sancionadores julgados de 2000 a maio de 2014, bem como a maneira pela qual se comportou o Poder Judiciário brasileiro quando à frente de dois casos envolvendo decisões negociais malsucedidas. Como se verá, é patente a diferença técnica entre os dois órgãos julgadores, sendo gravemente preocupante a forma como juízes brasileiros encararam a atuação dos administradores nesses casos.

E, ainda no Capítulo 5, far-se-á uma breve análise de como a business judgment rule foi aplicada em casos decorrentes da mais recente crise financeira mundial: a crise dos subprime. 


\section{CAPÍTULO 1 - A ADMINISTRAÇÃO DAS SOCIEDADES ANÔNIMAS}

A administração das sociedades anônimas é regulada conforme as regras do Capítulo XII da Lei das S.A. Nele, o legislador define quantos e quais órgãos administram uma companhia, bem como a maneira pela qual eles funcionam, suas competências, seus deveres e obrigações e seu regime de responsabilização.

Como já adiantado na Introdução ao presente trabalho, este primeiro capítulo abordará os órgãos administrativos de sociedades anônimas, em conformidade com o sistema dualista adotado pela Lei das S.A., e o processo decisório inerente a cada órgão (se disjunto, conjunto ou colegial). Além disso, analisar-se-á a natureza da obrigação dos administradores e o dever de diligencia, o principal dever fiduciário desses profissionais.

\subsection{O sistema dualista brasileiro}

Os órgãos da administração das companhias são estruturados, pelos ordenamentos jurídicos, conforme um de dois sistemas: o monista e o dualista.

O primeiro foi criado na França e atribui a administração da sociedade exclusivamente à diretoria. Dentre os membros desse órgão, um é eleito para exercer o cargo de diretor-presidente, que possui certas funções específicas, mas não constitui um outro órgão de administração ${ }^{4}$.

O segundo sistema (dualista), criado na Alemanha em 1884, tem como principal pilar a existência de dois órgãos de administração em uma companhia: a diretoria e o conselho de administração. De acordo com ADAMEK,

Essa forma de estruturação da administração foi concebida para eliminar as deficiências verificadas no sistema monista: buscou, sobretudo, compensar, de um lado, a inércia do conselho de administração - que, no sistema monista, muito raramente exerce papel ativo na condução da empresa - e, de outro, procurou aumentar o controle dos acionistas sobre a administração cotidiana, exercida pelo diretor-geral $(. . .)^{5}$.

\footnotetext{
${ }^{4}$ ADAMEK, Marcelo Vieira von. Responsabilidade Civil dos Administradores de S/A e as ações correlatas. São Paulo: Saraiva, 2009. p. 17-18.

${ }^{5}$ Ibid., p. 18.
} 
O direito brasileiro, por meio do Decreto-Lei n ${ }^{\circ} 2.627$, de 26 de setembro de 1940, adotou, primeiramente, o sistema monista. Apesar de muitas sociedades anônimas de grande porte e de economia mista já instituírem a lógica dualista da administração em seus estatutos ${ }^{6}$, o decreto só previa a existência da diretoria.

Assim versava o seu artigo 116: "A sociedade anônima ou companhia será administrada por um ou mais diretores, acionistas ou não, residentes no país, escolhidos pela assembléia geral, que poderá destituí-los a todo tempo”.

E isso se explica, em boa parte, em razão do repúdio de VALVERDE, um dos autores do anteprojeto do Decreto-Lei $\mathrm{n}^{\circ} 2.627 / 40$, ao conselho de administração. Segundo ele,

O nosso sistema é, fora de toda dúvida e sobre todos os pontos de vista, superior ao sistema administrativo das sociedades anônimas estrangeiras, cujos Conselhos de Administração, compostos de dezenas de pessoas que não trabalham, na maioria incompetentes, mas que recebem grandes porcentagens sobre os lucros sociais, constituem, na opinião hoje generalizada, o cancro das sociedades anônimas 7 .

Com a entrada em vigor da Lei das S.A., o cenário da administração no ordenamento jurídico nacional foi modificado. Passou-se do sistema monista para o dualista. De acordo com o artigo 138 dessa lei, “a administração da companhia competirá, conforme dispuser o estatuto, ao conselho de administração e à diretoria, ou somente à diretoria".

Como observa LEÃO JR., a transformação se deu, em boa parte, por conta da hipertrofia dos órgãos da administração e a falta de condições da assembleia geral em comandar as principais decisões administrativas, que, ao longo do

\footnotetext{
${ }^{6}$ Vale a observação de LEÃO JR.: “Ao ser elaborado o projeto da LSA, e não obstante a orientação do Decreto-lei no 2.627/1940, a dualidade de órgãos administrativos já era adotada tanto nas sociedades de economia mista (as leis que criaram a Petrobras e a Eletrobrás previam Conselho de Administração e Diretoria) quanto em grandes empresas privadas, mediante distinção no estatuto e eleição, pela Assembléia Geral de Diretores com atribuições de membros de um Conselho, como órgão de deliberação colegiada, e Diretores Executivos, com poderes de representação da companhia” LEÃO JR., Luciano de Souza. Conselho de Administração e Diretoria: Administração da Companhia. In: LAMY FILHO, Alfredo; PEDREIRA, José Luiz Bulhões (Org.). Direito das Companhias. Rio de Janeiro: Forense, 2009. p. 1030.

${ }^{7}$ VALVERDE, Trajano de Miranda. Sociedade por Ações. $2^{\mathrm{a}}$ ed. v. 2. Rio de Janeiro: Forense, 1953. p. 292.
} 
século XX, passaram a exigir cada vez maiores conhecimentos técnicos ${ }^{8}$. Continua o autor:

\begin{abstract}
Uma das razões para a dualidade de órgãos de administração é a capacidade limitada da Assembléia Geral de exercer com eficiência as atribuições de orientar os negócios sociais e fiscalizar os administradores apenas em reuniões anuais ou esporádicas dos acionistas que são, na maioria, investidores, sem interesse, conhecimento ou experiência no acompanhamento dos problemas da administração dos negócios sociais, a não ser na companhia com poder de controle pré-constituído (v. § 238), ou seja, em que existe acionista controlador, ou sociedade controladora, que exerce permanentemente suas funções. A subordinação dos diretores ao Conselho de Administração com funções deliberativas composto, ao menos na maioria, por pessoas distintas, que são remuneradas pelo exercício do cargo e podem reunir-se com maior frequência, assegura fiscalização mais eficiente dos órgãos executivos ${ }^{9}$.
\end{abstract}

LEÃO JR. explica, ainda, que outro ponto positivo da presença do conselho de administração é o reforço à proteção dos direitos dos acionistas minoritários:

Além disso, a existência de órgão de deliberação colegiada com as funções que a LSA atribui a Conselho cujos membros são eleitos pela Assembleia Geral pelo processo de voto múltiplo, possibilita, mesmo nas companhias em que há controle pré-constituído, a representação no órgão de diferentes grupos de acionistas, o que aumenta, de modo apreciável, a proteção dos direitos das minorias ${ }^{10}$.

Assim sendo, desde a entrada em vigor da Lei das S.A., em 1977, a administração das companhias passou a contar com um conselho de administração facultativo, de deliberação colegiada e com atribuições específicas, e uma diretoria obrigatória, que representa a sociedade perante terceiros e executa as deliberações da assembleia geral e do conselho.

\title{
1.1.1 O conselho de administração
}

O conselho de administração é o órgão que, na estrutura de uma sociedade anônima, se insere entre a assembleia geral e a diretoria ${ }^{11}$. É obrigatório em

\footnotetext{
${ }^{8}$ LEÃO JR., Luciano de Souza. Conselho de Administração e Diretoria: Administração da Companhia. In: LAMY FILHO, Alfredo; PEDREIRA, José Luiz Bulhões (Org.). Direito das Companhias. Rio de Janeiro: Forense, 2009. p. 1030.

${ }^{9}$ Ibid., p. 1030.

${ }^{10}$ Ibid., p. 1031.

${ }^{11}$ ADAMEK, Marcelo Vieira von. Responsabilidade Civil dos Administradores de S/A e as ações correlatas. São Paulo: Saraiva, 2009. p. 21.
} 
companhias abertas, de capital autorizado e de economia mista, como dispõem os artigos $138^{12}$ e $239^{13}$ da Lei das S.A., sendo facultativo nas demais.

As competências desse órgão, segundo o artigo 142, são, principalmente, fixar a orientação geral dos negócios da companhia e eleger e destituir os membros da diretoria, bem como fiscalizar a sua gestão. Quando autorizado ou exigido pelo estatuto, pode esse órgão deliberar sobre a emissão de ações ou bônus de subscrição e autorizar a alienação de bens do ativo não circulante, a constituição de ônus reais e a prestação de garantias a obrigações de terceiros. É de sua competência, ainda, a escolha e destituição de auditores independentes, se houver.

Como ressalta PARENTE, "o conselho de administração constitui um órgão deliberativo e fiscalizador, na medida em que orienta, em termos gerais, a condução dos negócios sociais e físcaliza a atuação dos diretores"14.

Nesse sentido, conclui-se que o órgão em questão não participa do dia a dia da companhia e não é responsável por sua administração diária. Nas palavras do ex-diretor da CVM Luiz Antonio de Sampaio Campos, “embora o Conselho de Administração tenha funcionamento permanente, a atividade ou atuação de seus membros é apenas parcial. Eles não estão diariamente na companhia e não se exige que estejam"15.

Nos termos do artigo 140 da Lei das S.A., o conselho de administração deve ser composto por, no mínimo, três membros, acionistas ou não, eleitos e

\footnotetext{
12 “Art. 138. A administração da companhia competirá, conforme dispuser o estatuto, ao conselho de administração e à diretoria, ou somente à diretoria.

$\S 1^{\circ} \mathrm{O}$ conselho de administração é órgão de deliberação colegiada, sendo a representação da companhia privativa dos diretores.

$\S 2^{\circ}$ As companhias abertas e as de capital autorizado terão, obrigatoriamente, conselho de administração".

13 “Art. 239. As companhias de economia mista terão obrigatoriamente Conselho de Administração, assegurado à minoria o direito de eleger um dos conselheiros, se maior número não lhes couber pelo processo de voto múltiplo.

Parágrafo único. Os deveres e responsabilidades dos administradores das companhias de economia mista são os mesmos dos administradores das companhias abertas".

${ }^{14}$ PARENTE, Flávia. O Dever de Diligência dos Administradores de Sociedades Anônimas. Rio de Janeiro: Renovar, 2005. p. 9.

${ }^{15}$ Processo Administrativo Sancionador CVM n 31/00, Rel. Norma Jonssen Parente, j. em 10 jul. 2003.
} 
destituíveis a qualquer tempo pela assembleia geral ${ }^{16 / 17}$, sendo que o estatuto social definirá os detalhes de seu funcionamento.

O artigo $143, \S 1^{\circ}$, da Lei das S.A. determina que até somente $1 / 3$ dos conselheiros poderá cumular seu cargo com o cargo de diretor de uma mesma companhia. Assim, “a norma evita que a dualidade de órgãos de administração seja eliminada de fato, mediante exercício, pelas mesmas pessoas naturais, da maioria dos cargos do Conselho de Administração e da Diretoria"18.

Ainda no que se refere à composição do conselho, cumpre destacar que a doutrina questiona a independência dos conselheiros perante os acionistas. Segundo ARAGÃO:

Sua indicação, desde o início, nada mais representa do que a nomeação de um preposto para representar o acionista na reunião do Conselho de Administração, e não a indicação de um terceiro verdadeiramente independente, que irá representar, de forma não particular, o interesse de todos os acionistas ${ }^{19}$.

Em vista disso, a Lei das S.A., em seu artigo $154, \S 1^{\circ}$, determinou que o administrador eleito por determinado acionista, antes de observar o interesse do

\footnotetext{
${ }^{16}$ Art. 140. O conselho de administração será composto por, no mínimo, 3 (três) membros, eleitos pela assembléia-geral e por ela destituíveis a qualquer tempo, devendo o estatuto estabelecer:

I - o número de conselheiros, ou o máximo e mínimo permitidos, e o processo de escolha e substituição do presidente do conselho pela assembléia ou pelo próprio conselho;

II - o modo de substituição dos conselheiros;

III - o prazo de gestão, que não poderá ser superior a 3 (três) anos, permitida a reeleição;

IV - as normas sobre convocação, instalação e funcionamento do conselho, que deliberará por maioria de votos, podendo o estatuto estabelecer quorum qualificado para certas deliberações, desde que especifique as matérias.

Parágrafo único. O estatuto poderá prever a participação no conselho de representantes dos empregados, escolhidos pelo voto destes, em eleição direta, organizada pela empresa, em conjunto com as entidades sindicais que os representem.

${ }^{17}$ LEÃO JR. escreve que "o requisito legal de, no mínimo, três membros, visa a preservar a natureza colegial do órgão” LEÃO JR., Luciano de Souza. Conselho de Administração e Diretoria: Administração da Companhia. In: LAMY FILHO, Alfredo; PEDREIRA, José Luiz Bulhões (Org.). Direito das Companhias. Rio de Janeiro: Forense, 2009. p. 1034. ADAMEK observa, a esse respeito, que "teria sido recomendável que a lei fixasse número máximo, como o de 18 (dezoito) (adotado pelo direito francês), acima do qual também não se estaria perante um conselho, mas assembléia ou comício, de cujo funcionamento eficiente se pode, a justo título, duvidar" ADAMEK, Marcelo Vieira von. Responsabilidade Civil dos Administradores de S/A e as ações correlatas. São Paulo: Saraiva, 2009. p. 20.

${ }^{18}$ LEÃO JR., Luciano de Souza. Conselho de Administração e Diretoria: Administração da Companhia. In: LAMY FILHO, Alfredo; PEDREIRA, José Luiz Bulhões (Org.). Direito das Companhias. Rio de Janeiro: Forense, 2009. p. 1035.

${ }^{19}$ ARAGÃO, Paulo Cesar. A disciplina do acordo de acionistas na reforma da lei das sociedades por ações: Lei $\mathrm{n}^{\circ}$ 10.303/2001. In: LOBO, Jorge (Org.) Reforma da lei das sociedades anônimas: inovações e questões controvertidas da Lei $n^{\circ} 10.303$, de 31/10/2001. Rio de Janeiro: Forense, 2002. p. 376.
} 
seu eleitor, tem a obrigação de cumprir com seus deveres fiduciários perante a companhia. Assim versa a norma:

Art. 154. (...)

$\S 1^{\circ}$. O administrador eleito por grupo ou classe de acionistas tem, para com a companhia, os mesmos deveres que os demais, não podendo, ainda que para defesa do interesse dos que o elegeram, faltar a esses deveres.

O Regulamento de Listagem do Novo Mercado também se arma contra a possível falta de independência dos conselheiros. De acordo com ele, o conselho de administração de companhias listadas no referido segmento da BM\&FBovespa deve ser composto por, no mínimo, cinco membros, dos quais ao menos $20 \%$ deverão ser independentes (item 4.3).

O conceito de conselheiro independente, por sua vez, é assim definido pelo regulamento:

"Conselheiro Independente" caracteriza-se por: (i) não ter qualquer vínculo com a Companhia, exceto participação de capital; (ii) não ser Acionista Controlador, cônjuge ou parente até segundo grau daquele, ou não ser ou não ter sido, nos últimos 3 anos, vinculado a sociedade ou entidade relacionada ao Acionista Controlador (pessoas vinculadas a instituições públicas de ensino e/ou pesquisa estão excluídas desta restrição); (iii) não ter sido, nos últimos 3 anos, empregado ou diretor da Companhia, do Acionista Controlador ou de sociedade controlada pela Companhia; (iv) não ser fornecedor ou comprador, direto ou indireto, de serviços e/ou produtos da Companhia, em magnitude que implique perda de independência; (v) não ser funcionário ou administrador de sociedade ou entidade que esteja oferecendo ou demandando serviços e/ou produtos à Companhia; (vi) não ser cônjuge ou parente até segundo grau de algum administrador da Companhia; (vii) não receber outra remuneração da Companhia além da de conselheiro (proventos em dinheiro oriundos de participação no capital estão excluídos desta restrição).

Também é importante mencionar, aqui, que as deliberações do conselho de administração são tomadas em reuniões, sendo, portanto, sempre colegiadas, na medida em que nenhum conselheiro emite decisões individualmente. A esse respeito, contudo, é importante trazer a advertência de ADAMEK, no sentido de que isso não isenta os conselheiros de determinados deveres individuais:

A LSA não prevê competência individual para os membros do conselho de administração, mas pressupõe, e previu, deveres próprios de sua atuação isolada. O exemplo talvez mais evidente patenteia-se no dever geral de fiscalização (pautado pelo standard legal de diligência) que cabe a cada um dos conselheiros e de cujo descumprimento resulta a responsabilidade solidária (LSA, art. $\left.158, \S 1^{\circ}\right)^{20}$.

\footnotetext{
${ }^{20}$ ADAMEK, Marcelo Vieira von. Responsabilidade Civil dos Administradores de S/A e as ações correlatas. São Paulo: Saraiva, 2009. p. 22.
} 
Por fim, é importante mencionar que aos conselheiros não compete a representação da companhia perante terceiros. Eles não podem, por exemplo, assinar contratos em nome da sociedade. Tal função é exclusiva da diretoria ${ }^{21}$.

\subsubsection{A diretoria}

Ao contrário do conselho de administração, a diretoria é órgão obrigatório em toda e qualquer companhia. Trata-se, normalmente, de um corpo mais técnico, cujos integrantes possuem e executam funções específicas de uma empresa.

De acordo com o artigo 143 da Lei das S.A. ${ }^{22}$, ela deve ser composta por pelo menos dois diretores, acionistas ou não, eleitos e destituíveis a qualquer tempo pelo conselho de administração. Se este não existir, será a assembleia geral de acionistas quem os elegerá e os destituirá.

Também diferentemente do conselho de administração, os membros da diretoria agem individualmente, tendo, na maioria dos casos, funções específicas. Contudo, nada impede que o estatuto estabeleça que determinadas matérias deverão ser deliberadas por meio de reunião da diretoria.

Sendo assim, os diretores geralmente praticam atos de gestão sem a necessidade de uma deliberação colegial. O diretor de operações define qual a melhor forma de se concretizar um projeto, o diretor financeiro decide em quais

\footnotetext{
${ }^{21}$ Com algumas exceções, como se verá no próximo item.

22 “Art. 143. A Diretoria será composta por 2 (dois) ou mais diretores, eleitos e destituíveis a qualquer tempo pelo conselho de administração, ou, se inexistente, pela assembléia-geral, devendo o estatuto estabelecer:

I - o número de diretores, ou o máximo e o mínimo permitidos;

II - o modo de sua substituição;

III - o prazo de gestão, que não será superior a 3 (três) anos, permitida a reeleição;

IV - as atribuições e poderes de cada diretor.

$\S 1^{\circ}$ Os membros do conselho de administração, até o máximo de $1 / 3$ (um terço), poderão ser eleitos para cargos de diretores.

$\S 2^{\circ} \mathrm{O}$ estatuto pode estabelecer que determinadas decisões, de competência dos diretores, sejam tomadas em reunião da diretoria".
} 
e em quantos ativos investirá, o diretor de marketing determina qual a melhor forma de alcançar o público alvo da companhia etc. ${ }^{23}$.

Há, portanto, uma discricionariedade individual conferida a cada diretor, que leva em conta sua especialidade técnica, é limitada às atribuições conferidas pela lei e o estatuto social e deve sempre observar o interesse social e visar a lograr os fins da companhia.

A importância da diretoria se mostra na medida em que é o órgão que executa o que for deliberado pela assembleia geral e pelo conselho de administração. É o órgão que coloca em prática a consecução do objeto social.

Nas palavras de EIZIRIK:

Compete aos diretores, em princípio, praticar todos os atos necessários ao funcionamento regular da companhia, ou seja, aqueles referentes à sua gestão ordinária, dirigidos direta ou indiretamente à consecução do objeto social $(\ldots)^{24}$.

Além disso, a diretoria detém o poder exclusivo de representação da companhia, resguardadas poucas exceções ${ }^{25}$. Mas, ressalve-se que, em que pese ser um órgão da própria companhia (e não um corpo externo), que exprime sua

\footnotetext{
${ }^{23}$ De acordo com LEÃO JR., "As atribuições em geral são definidas segundo cargos usualmente designados, entre outros, Diretor-Presidente, industrial, financeiro, comercial e administrativo, que compreendem a direção e fiscalização de determinadas atividades e serviços da empresa" LEÃO JR., Luciano de Souza. Conselho de Administração e Diretoria: Administração da Companhia. In: LAMY FILHO, Alfredo; PEDREIRA, José Luiz Bulhões (Org.). Direito das Companhias. Rio de Janeiro: Forense, 2009. p. 1063-1064.

${ }^{24}$ EIZIRIK, Nelson. A Lei das S/A Comentada. vol. II. São Paulo: Quartier Latin, 2011. p. 304.

${ }^{25}$ Conforme bem adverte ADAMEK, há três possíveis exceções à exclusividade de representação da companhia conferida à diretoria: "É controvertido se haveria (e quais seriam) exceções à regra de que a representação cabe exclusivamente aos diretores. A primeira exceção a ser lembrada refere-se à representação da companhia durante a liquidação, que então toca privativamente ao liquidante (LSA, art. 211). Cabe reconhecer que se trata de situação especial, pois não ocorre durante a vida ordinária da companhia, mas no período excepcional de sua liquidação. A segunda exceção envolve as situações raríssimas em que a companhia não tiver conselho de administração e ocorrer vacância de todos os cargos da diretoria, hipótese em que o acionista controlador deve praticar os atos urgentes de administração até a realização da assembléia geral (LSA, art. 150, § $2^{\circ}$ ). A terceira exceção, cogitada por alguns doutrinadores, ocorreria durante a contratação de auditor independente por escolha do Conselho Fiscal (LSA, art. 163, $\S 4^{\circ}$ ), quando então há quem entenda que o contrato de prestação de serviços poderia ser assinado diretamente pelo próprio presidente do Conselho Fiscal. Mas o ponto de vista é contestável. Outra parcela da doutrina entende que, mesmo nesta hipótese, o contrato haveria de ser assinado pelo diretor: a faculdade de escolher e fixar os honorários do auditor não implica outorga de poderes para que o órgão, através de seu membro, assine o contrato" ADAMEK, Marcelo Vieira von. Responsabilidade Civil dos Administradores de S/A e as ações correlatas. São Paulo: Saraiva, 2009. p. 25.
} 
vontade e no seu interesse, a diretoria, para usar a expressão de MIRANDA, presenta a sociedade ${ }^{26 / 27}$.

\subsection{Administração disjunta, conjunta e colegial}

Como descreve ADAMEK, a doutrina separa os órgãos das companhias em órgãos singulares e órgãos plurais, sendo estes subdivididos conforme o seu modo de funcionamento. Nas palavras do autor:

(...) de acordo com o número de titulares, os órgãos classificam-se em órgãos singulares, compostos por um titular, e órgãos plurais, com dois ou mais titulares. Tendo em vista o modo de funcionamento, os órgãos plurais podem ser sucessivos, quando a atuação de um titular se opera na falta ou impedimento do outro, ou simultâneos, quando há simultaneidade dos poderes dos vários administradores. Nesta última situação, os órgãos dividem-se em órgãos de funcionamento disjunto (ou separado), quando cada titular seu pode atuar sozinho, tendo poderes iguais e independentes dos outros titulares, salvo na medida em que algum deles tenha o direito de se opor a outro; conjunto (ou coletivo), quando os vários titulares devem atuar em um ou mais grupos, independentemente de deliberação em conselho ou assembléia; e colegial, quando os titulares do órgão plural atuam em grupo, mediante deliberação tomada em reunião, atendido certo procedimento jurídico ${ }^{28}$.

Nessa classificação, verifica-se que o conselho de administração e a diretoria são órgãos plurais, pois que a Lei das S.A. veda a sua composição por apenas um membro (artigos 140 e 143). Mais especificamente, o conselho é um órgão plural de funcionamento simultâneo colegial, ao passo que a diretoria pode ser órgão plural de funcionamento simultâneo disjunto, conjunto ou colegial.

\footnotetext{
${ }^{26}$ MIRANDA, Pontes de. Tratado de Direito Privado. Parte Especial. Tomo L. $3^{\mathrm{a}}$ ed. Rio de Janeiro: Editor Borsoi, 1972. p. 385.

${ }^{27}$ Nesse sentido, cite-se mais um trecho de EIZIRIK: "Na representação há duas vontades, a do representante e a do representado; na atuação do administrador só existe uma vontade, que é da sociedade, a qual se manifesta pelos membros do órgão dotado de competência para tanto.

Assim, a expressão "representação da companhia" constitui pura conveniência terminológica, de vez que não há representação no sentido técnico jurídico. Os administradores, investidos do "poder de representação", agem como se fossem a companhia, já que a administração de que participam constitui um órgão integrante da estrutura da pessoa jurídica" EIZIRIK, Nelson. A Lei das S/A Comentada. vol. 2. São Paulo: Quartier Latin, 2011. p. 303.

${ }_{28}$ ADAMEK, Marcelo Vieira von. Responsabilidade Civil dos Administradores de S/A e as ações correlatas. São Paulo: Saraiva, 2009. p. 22.
} 
“Colégio", diz LEÃO JR., "é grupo de pessoas com o mesmo status, ou que exercem as mesmas funções, e deliberação colegiada é decisão sobre ato voluntário por conjunto de pessoas que são membros de um colégio" ${ }^{29}$.

Nessa linha, o autor assim define a decisão colegiada:

A decisão colegiada é ato coletivo - conjunto de atos de vontade individuais que formam um único ato porque organizados pelo procedimento de deliberação, que compreende ao menos (a) a comunicação, a todos os membros do colégio, da instalação do processo de deliberação e da proposta a ser votada, (b) a manifestação dos membros sobre a proposta com o fim de formar a vontade social, e (c) a coleta dessas manifestações e proclamação da deliberação ${ }^{30}$.

Como já se disse, o conselho de administração é, em sua essência, órgão de atuação colegial. Apesar de seus membros possuírem certas atribuições individuais, como o dever de fiscalização daquilo que ocorre na companhia, as decisões proferidas por esse órgão serão sempre resultado de uma deliberação ocorrida em reunião de seus membros.

Dessa forma, a fixação da orientação geral dos negócios da sociedade, a eleição dos diretores e as demais matérias de competência do conselho de administração serão decididas sempre e somente por meio de uma decisão colegiada.

A diretoria, pelo contrário, é órgão de atuação predominantemente individual, uma vez que as decisões proferidas por seus membros não costumam ser precedidas de deliberações. Diz-se predominantemente porque, como já visto, o estatuto social pode determinar que certas matérias deverão ser definidas por meio de reunião da diretoria ou por grupos de diretores (o que ocorre quando o estatuto exige que determinado contrato seja assinado por certos diretores, por exemplo). Nessas situações, então, ela age como órgão colegial e conjunto, respectivamente.

\footnotetext{
${ }^{29}$ LEÃO JR., Luciano de Souza. Conselho de Administração e Diretoria: Administração da Companhia. In: LAMY FILHO, Alfredo; PEDREIRA, José Luiz Bulhões (Org.). Direito das Companhias. Rio de Janeiro: Forense, 2009. p. 1031.

${ }^{30}$ Ibid., p. 1031.
} 
Portanto, como se pôde ver, o processo decisório dos administradores se difere na medida em que atuam disjunta, conjunta ou colegiadamente. E isso tem implicância direta com a responsabilização pessoal dos decisores, como se verá ao longo desta monografia ${ }^{31}$.

\subsection{Uma obrigação de meio}

A obrigação de um administrador de sociedade anônima, evidentemente, se caracteriza como uma obrigação de fazer, visto que não há uma coisa a ser entregue por ele à companhia. Sua obrigação consiste em administrar as atividades empresariais desse tipo societário.

Deve-se examinar, no entanto, se essa obrigação é de meio ou de resultado. Isto é, o administrador está vinculado à consecução de um resultado ou o seu dever consiste em empreender os melhores esforços em sua atividade, sem comprometimento com o resultado?

De acordo com CASTRO NEVES, nos casos em que houver uma obrigação de resultado, “o pleno adimplemento (...) apenas ocorrerá se o objetivo for atingido" 32 . Um exemplo seria o corretor de imóveis, cuja remuneração só lhe será devida se ele conseguir vender o imóvel de seu cliente ${ }^{33}$.

Nas hipóteses de obrigação de meio, por outro lado, "o devedor dessa obrigação deve apenas fazer o melhor" ${ }^{34}$. Exemplos são a atividade médica e a advocacia, cuja remuneração não está atrelada a um resultado, mas, sim, ao comprometimento de que o devedor fará o melhor que puder no exercício de suas funções.

\footnotetext{
${ }^{31}$ Confira-se, mais especificamente, o item 3.2.2.

${ }^{32}$ CASTRO NEVES, José Roberto de. Direito das Obrigações. 2 ed. Rio de Janeiro: GZ Ed., 2009. p. 115.

${ }^{33}$ Ibid., p. 115.

${ }^{34}$ Ibid., p. 115.
} 
Citando decisão da Corte de Cassação francesa tomada em 1936, CASTRO NEVES assim diferencia o ônus da prova em obrigações de meio e de resultado:

nas obrigações de resultado, para que o devedor afaste a sua responsabilidade, deve demonstrar que o resultado desejado deixou de ocorrer por fato que não lhe pode ser imputado, ao passo que nas obrigações de meio, cabe ao credor provar a falta de diligência do devedor ${ }^{35}$.

Nesse sentido, pode-se concluir que o administrador, no exercício de sua atividade, não tem uma obrigação de resultado, ou seja, a sua obrigação não consiste em trazer lucros para a companhia. Consiste, na verdade, em empreender os seus melhores esforços para isso.

Como ensina ADAMEK, "o administrador obriga-se apenas a adotar comportamento apropriado, com a diligência requerida, para a consecução de determinado fim, (...) mas não se obriga pela efetiva obtenção de resultado"36. Assim complementa:

(...) o que os acionistas legitimamente podem esperar e exigir, sim, é que os administradores atuem de forma idônea a cumprir com a finalidade lucrativa da companhia, mas não podem pretender responsabilizá-los por não terem feito fortuna. Ou seja, os administradores não se obrigam a obter resultados econômicos positivos, senão a realizar atividade apropriada e voltada para esse fim. Logo, o dano sofrido pela companhia não basta, por si só, para deflagrar o dever de indenizar ${ }^{37}$.

A Lei das S.A. adota esse entendimento em seu artigo 153, segundo o qual "o administrador da companhia deve empregar, no exercício de suas funções, o cuidado e diligência que todo homem ativo e probo costuma empregar na administração dos seus próprios negócios”. Define-se, com isso, um padrão de conduta próprio aos administradores quando do cumprimento de suas obrigações.

Trata-se do dever de diligência, principal pilar do regime de deveres e responsabilidades dos administradores de sociedades anônimas.

\footnotetext{
${ }^{35}$ Ibid., p. 115.

${ }^{36}$ ADAMEK, Marcelo Vieira von. Responsabilidade Civil dos Administradores de S/A e as ações correlatas. São Paulo: Saraiva, 2009. p. 132.

${ }^{37}$ Ibid., p. 133.
} 


\section{$1.4 \quad 0$ dever de diligência e seus aspectos}

O dever de diligência é a base de todos os demais deveres fiduciários impostos aos administradores no direito brasileiro. Nesse sentido, a exposição de motivos da Lei das S.A., em referência à seção de deveres e responsabilidades dos administradores, aponta que

as normas [dessa seção] são, em sua maior parte, meros desdobramentos e exemplificações do padrão de comportamento dos administradores definido pela lei em vigor - o do "homem ativo e probo na administração dos seus próprios negócios" $(. . .)^{38}$.

À primeira vista, pela leitura do artigo 153 acima transcrito, aparenta o legislador ter adotado o modelo do bonus pater familias como padrão de conduta dos administradores de sociedades anônimas. Porém, esse modelo faz referência a uma pessoa avessa a riscos, que não arriscaria seu patrimônio visando a aumentá-lo.

O bom pai de família, por isso, não pode ser a melhor interpretação para o dispositivo. Pelo contrário, o administrador não pode ser avesso a riscos; deve ele adotar posturas criativas e inovadoras. Assim entende CAMPOS:

(...) o comportamento do bom pai de família não se ajusta ao administrador da companhia. O modelo teórico do bom pai de família, proveniente do direito romano, remete a uma pessoa conservadora e avessa a riscos, preocupada mais em preservar o patrimônio do que em aumentálo. A estrutura da companhia pressupõe a propensão ao risco empresarial e, muitas vezes, a adoção de posturas criativas e inovadoras ${ }^{39 / 40}$.

A doutrina, então, prefere a adoção da figura do homem de negócios à do bom pai de família, adequando-se, assim, ao cotidiano e às necessidades da administração de sociedades empresárias ${ }^{41}$.

\footnotetext{
${ }^{38}$ Exposição de Motivos n 196, de 24 de junho de 1976, do Ministério da Fazenda.

${ }^{39}$ CAMPOS, Luiz Antonio de Sampaio. Deveres e Responsabilidades. In: LAMY FILHO, Alfredo; PEDREIRA, José Luiz Bulhões (Org.). Direito das Companhias. Rio de Janeiro: Forense, 2009. p. 1101. ${ }^{40}$ RIBEIRO também compreende dessa forma: "a gestão do bônus pater familias é mais conservadora e inversora do patrimônio, visa mais a prudência do que a informação e impede tratar o patrimônio com uma visão empresarial" RIBEIRO, Renato Ventura. Dever de diligência dos administradores de sociedades. São Paulo: Quartier Latin, 2006. p. 214.

${ }^{41}$ Nessa direção, CAMPOS afirma o seguinte: "Com efeito, o critério da LSA está intimamente ligado ao do homem de negócios, o businessman do direito anglo-saxão, e não o bom pai de família do direito romano. Exige-se que o homem seja ativo e probo, que tenha aptidão para a realização de negócios" CAMPOS, Luiz Antonio de Sampaio. Deveres e Responsabilidades. In: LAMY FILHO, Alfredo; PEDREIRA, José Luiz Bulhões (Org.). Direito das Companhias. Rio de Janeiro: Forense, 2009. p. 1.098.
} 
Outro ponto do artigo 153 da Lei das S.A. se dá no fato de que o legislador fixou nele um conceito aberto do dever de diligência. Tendo em vista a complexidade e a diversidade das situações que se dão no dia a dia das empresas, a adoção de um sistema exaustivo ou exemplificativo seria plenamente inviável.

O legislador certamente erraria se tentasse impor aos administradores um dever de diligência objetivo, estabelecendo um rol de condutas recrimináveis, como o faz com o dever de lealdade ${ }^{42}$. "A dificuldade", escreve CAMPOS, "estaria no fato de que qualquer modelo que se desenhasse nesse terreno fatalmente apresentar-se-ia muito rígido para determinadas situações e demasiadamente simples para outras (...)" ${ }^{» 33}$.

A delimitação dos contornos do conceito do dever de diligência fica, portanto, a cargo da doutrina e jurisprudência, que, ao logo do tempo, desenvolveram cinco aspectos nos quais tal dever se desdobra: (i) o dever de se informar; (ii) o dever de se qualificar; (iii) o dever de vigilância; (iv) o dever de investigar; e (v) o dever de intervir.

\subsubsection{O dever de se informar}

O dever de se informar ganhou destaque com o julgamento, pela Suprema Corte de Delaware, do caso Smith v. Van Gorkom, em que os administradores deliberaram a venda da companhia sem estarem devidamente informados.

Entendeu-se que os administradores não podem tomar decisões negociais de maneira desinformada. De acordo com a corte, "a director's duty to inform

\footnotetext{
${ }^{42} \mathrm{O}$ artigo 155 da Lei das S.A., que trata do dever de lealdade dos administradores de sociedades anônimas, traz, em seu caput, um rol exemplificativo de condutas que lhes são vedadas por conta desse dever, quais sejam: (i) usar, em benefício próprio ou de outrem, com ou sem prejuízo para a companhia, as oportunidades comerciais de que tenha conhecimento em razão do exercício de seu cargo; (ii) omitirse no exercício ou proteção de direitos da companhia ou, visando à obtenção de vantagens, para si ou para outrem, deixar de aproveitar oportunidades de negócio de interesse da companhia; e (iii) adquirir, para revender com lucro, bem ou direito que sabe necessário à companhia, ou que esta tencione adquirir. ${ }^{43}$ CAMPOS, Luiz Antonio de Sampaio. Deveres e Responsabilidades. In: LAMY FILHO, Alfredo; PEDREIRA, José Luiz Bulhões (Org.). Direito das Companhias. Rio de Janeiro: Forense, 2009. p. 1.098.
} 
himself in preparation for a decision derives from the fiduciary capacity in which he serves the corporation and its stockholders" 44 .

Nesse sentido, conforme RIBEIRO, “o dever de diligência exige que o administrador deva estar munido das informações necessárias (...), em especial, aquelas relevantes e razoavelmente disponíveis" 45 .

Dessa forma, não se demanda do administrador ter em mãos todas as informações existentes para que tome uma decisão. A quantidade de informações existentes costuma ser incontável, não sendo plausível exigir-se dele que reúna todas elas antes de qualquer decisão.

Deve-se levar em conta, a esse respeito, que uma decisão tomada de forma lenta pode sofrer graves punições advindas do mercado. Dependendo do caso, é menos custoso tomar uma decisão desinformada, mas rápida, do que recolher uma grande quantidade de informações e demorar para decidir sobre um determinado negócio.

Assim, como se verá com mais profundidade no item 4.2.3.3.1 desta monografia, o juízo de quanta informação é necessária para se tomar uma decisão deve ser do próprio administrador, e não do juiz ou do regulador. É o que entende CAMPOS:

(...) a informação necessária deverá ser examinada casuisticamente, à luz das circunstâncias específicas, não se devendo, inclusive, afastar o caráter subjetivo, no sentido de que quem deve, em princípio, julgar quais informações são necessárias para a tomada de decisão é o próprio administrador, notadamente em razão do corolário já estabelecido de que o julgador não se deve fazer substituir ao administrador, quanto ao mérito da decisão tomada ${ }^{46}$.

\subsubsection{O dever de se qualificar}

O segundo aspecto do dever de diligência desenvolvido pela doutrina e jurisprudência é o dever de se qualificar. Exige-se, como se pode induzir da sua

\footnotetext{
${ }^{44}$ Smith v, Van Gorkom, 488 A.2d 858 (1985).

${ }^{45}$ RIBEIRO, Renato Ventura. Dever de diligência dos administradores de sociedades. São Paulo: Quartier Latin, 2006. p. 226-227.

${ }^{46}$ CAMPOS, Luiz Antonio de Sampaio. Deveres e Responsabilidades. In: LAMY FILHO, Alfredo; PEDREIRA, José Luiz Bulhões (Org.). Direito das Companhias. Rio de Janeiro: Forense, 2009. p. 11061107.
} 
nomenclatura, que o administrador se qualifique para o exercício de suas funções.

\section{De acordo com EIZIRIK,}

(...) o administrador deve ter ou adquirir os conhecimentos mínimos sobre as atividades da companhia e a competência necessária ao desempenho de suas funções, com capacidade técnica para tomar decisões de maneira refletida e responsável. Assim, se o administrador não possui conhecimentos mínimos que lhe permitam dirigir os negócios sociais, não deve aceitar o cargo ${ }^{47}$.

Sendo assim, o administrador deve tanto se qualificar para o cargo que vier a assumir como manter a sua qualificação após a posse, aprimorando suas capacidades profissionais de acordo com as necessidades técnicas das suas funções.

Mas, em contrapartida, YAZBEK adverte que "não há como, nas grandes companhias contemporâneas, presumir [dos administradores] uma especialização ao mesmo tempo abrangente e aprofundada" ${ }^{48}$. De acordo com o autor,

aquele conselheiro especializado em, por exemplo, distribuição comercial no varejo, que pode cumprir importante papel em determinadas empresas, pode muito bem ter dificuldades para compreender operações financeiras mais complexas ${ }^{49}$.

Ele sugere, portanto, que a responsabilidade eventualmente atribuída ao administrador por falta de diligência seja medida de acordo com "o seu grau de especialização e a natureza dos problemas ocorridos" $"$.

Um exemplo de infração ao dever de se qualificar se deu no caso Francis v. United Jersey Bank, julgado pela Suprema Corte de Nova Jersey ${ }^{51}$. Entendeu-

\footnotetext{
${ }^{47}$ EIZIRIK, Nelson. A Lei das S/A Comentada. vol. II. São Paulo: Quartier Latin, 2011. p. 353.

${ }^{48}$ YAZBEK, Otávio. Representações do dever de diligência na doutrina jurídica brasileira: um exercício e alguns desafios. In: KUYVEN, Luiz Fernando Martins (Org.). Temas essenciais de direito empresarial: estudos em homenagem a Modesto Carvalhosa. São Paulo: Saraiva, 2012. p. 958.

${ }^{49}$ Ibid., p. 958.

${ }^{50}$ Ibid., p. 958.

${ }^{51}$ Francis v. United Jersey Bank, 162 N.J. Super. 355 (1978) 392 A.2d 1233.
} 
se, aqui, que um administrador, no exercício de seu trabalho, deve conhecer as atividades da sua companhia e os negócios nos quais ela está envolvida ${ }^{52}$.

\subsubsection{O dever de vigilância}

Outro aspecto do dever de diligência, o dever de vigilância se dá na obrigação do administrador em acompanhar os negócios de sua companhia. Também chamado de dever de monitoramento, esse aspecto exige dos administradores "uma vigilância geral, no sentido de monitorar o andamento dos negócios e a execução das deliberações e decisões tomadas" ${ }^{\text {53. }}$.

Não se exige, assim, uma vigilância sobre hábitos específicos e singulares do dia a dia da companhia ${ }^{54}$. Nessa direção escreve EIZIRIK:

(...) não se exige dos administradores a supervisão de cada uma das atividades desenvolvidas pela companhia, mas o acompanhamento geral dos negócios sociais e de suas políticas ou procedimentos internos ${ }^{55}$.

A Suprema Corte de Nova Jersey, no já citado caso Francis v. United Jersey Bank, expôs o mesmo entendimento: “directorial management does not require a detailed inspection of day-to-day activities, but rather a general monitoring of corporate affairs and policies" 56 .

Mesmo assim, a Sra. Pritchard, administradora da Pritchard \& Baird Intermediaries Corp., foi condenada por não ter sido diligente o suficiente para identificar abusos cometidos por seus filhos em detrimento da companhia após a

\footnotetext{
${ }^{52}$ Confira-se o seguinte trecho da decisão: "There are no controlling New Jersey cases in this area, and, in fact, I can find no New Jersey cases which are closely enough in point to be helpful in resolving our case. However, it seems to me that the inherent nature of a corporate director's job necessarily implies that he must have a basic idea of the corporation's activities. He should know what business the corporation is in, and he should have some broad idea of the scope and range of the corporation's affairs. In terms of our case, Mrs. Pritchard should have known that Pritchard \& Baird was in the reinsurance business as a broker and that it annually handled millions of dollars belonging to, or owing to, ceding companies and reinsurers. Charged with that knowledge, it seems to me that a director in Mrs. Pritchard's position had, at the bare minimum, an obligation to ask for and read the annual financial statements of the corporation. She would then have the obligation to react appropriately to what a reading of the statements revealed" Francis v. United Jersey Bank, 162 N.J. Super. 355 (1978) 392 A.2d 1233.

${ }^{53}$ CAMPOS, Luiz Antonio de Sampaio. Deveres e Responsabilidades. In: LAMY FILHO, Alfredo; PEDREIRA, José Luiz Bulhões (Org.). Direito das Companhias. Rio de Janeiro: Forense, 2009. p. 1107. ${ }^{54}$ Ibid., p. 1107.

${ }^{55}$ EIZIRIK, Nelson. A Lei das S/A Comentada. vol. II. São Paulo: Quartier Latin, 2011. p. 356.

${ }^{56}$ Francis v. United Jersey Bank, 162 N.J. Super. 355 (1978) 392 A.2d 1233.
} 
morte de seu marido, o principal acionista. Veja-se o seguinte trecho da decisão da mencionada corte:

There is no proof whatever that Mrs. Pritchard ever ceased to be fully competent. There is no proof that she ever made any effort as a director to question or stop the unlawful activities of Charles, Jr. and William. The actions of the sons were so blatantly wrongful that it is hard to see how they could have resisted any moderately firm objection to what they were doing. The fact is that Mrs. Pritchard never knew what they were doing because she never made the slightest effort to discharge any of her responsibilities as a director of Pritchard \& Baird ${ }^{57}$.

\subsubsection{O dever de investigar}

Durante a atividade de administração de companhias, inúmeras informações chegam aos diretores e conselheiros. Diante delas, como explica CAMPOS, "não devem os administradores ficar passíveis" 58 , mas, sim, criticamente examiná-las e indagar, dentre outras questões, se são informações completas e corretas, avaliando também quais os riscos envolvidos ${ }^{59}$.

Assim entendeu o Colegiado da CVM, no âmbito do julgamento do caso Sadia:

O dever de investigar, como corolário do dever de diligência, impõe aos administradores o dever de analisar criticamente as informações que lhes são fornecidas e, mais do que isso, apurar se tais informações merecem ser complementadas ${ }^{60}$.

Caso as informações recebidas se mostrem incompletas, superficiais ou imprecisas e possam colocar em risco o interesse e o patrimônio da companhia, o administrador estará à frente do que se chama de red flag, que, conforme EIZIRIK et al, se caracteriza por "situações que o deixem em estado de alerta"61. Então, ao identificar uma red flag, deverá o administrador agir e investigar minuciosamente as informações que tem em mãos.

\footnotetext{
${ }^{57}$ Francis v. United Jersey Bank, 162 N.J. Super. 355 (1978) 392 A.2d 1233.

${ }^{58}$ CAMPOS, Luiz Antonio de Sampaio. Deveres e Responsabilidades. In: LAMY FILHO, Alfredo; PEDREIRA, José Luiz Bulhões (Org.). Direito das Companhias. Rio de Janeiro: Forense, 2009. p. 1108. ${ }^{59}$ Ibid., p. 1108.

${ }^{60}$ Processo Administrativo Sancionador CVM no 18/08, Rel. Alexsandro Broedel Lopes, j. em 14 dez. 2010.

${ }^{61}$ EIZIRIK, Nelson; GAAL, Ariádna B.; PARENTE, Flávia; HENRIQUES, Marcus de Freitas. Mercado de Capitais: regime jurídico. Rio de Janeiro: Renovar, 2008. p. 433.
} 
No entanto, considerando que a carga de informações recebidas por um administrador é normalmente volumosa e que ele conta com o trabalho de terceiros, como auditores, advogados e empregados da própria companhia, não se pode dele exigir que examine a fundo todas as informações que lhe são passadas. Conselheiros e diretores podem, portanto, confiar em informações que lhes são disponibilizadas por pessoas de sua confiança ${ }^{62}$.

Cumpre destacar, ainda, que, como ocorre com o dever de se informar, também faz parte da discricionariedade dos administradores decidir o quanto devem investigar uma informação recebida. Nas palavras de PARENTE:

\begin{abstract}
Advirta-se que, assim como ocorre com o dever de se informar, o administrador, ao promover as investigações, deve considerar algumas variáveis, tais como, o custo que elas implicam e o tempo de que dispõe para empreender tal tarefa.

(...)

Assim, a extensão da investigação está dentro do âmbito do poder discricionário do administrador, que deverá sopesar as vantagens e desvantagens de requerer um estudo mais aprofundado das informações que lhes forem encaminhadas. Caberá, assim, ao administrador examinar a oportunidade e a conveniência de promover uma maior investigação a respeito das informações que obteve ${ }^{63}$.
\end{abstract}

\title{
1.4.5 O dever de intervir
}

Como já visto, uma atuação passiva dos administradores não é compatível com o dever de diligência. Nesse sentido, de acordo com o dever de intervir, compete aos conselheiros e diretores agir sempre de forma proativa, evitando possíveis prejuízos ou ofensas aos negócios da sociedade anônima.

Para RIBEIRO, “o dever de intervir (...) pressupõe que o administrador deve intervir nas operações, na forma e dentro dos limites de sua competência, nos casos em que tal intervenção se mostrar necessária"64.

Trata-se de uma derivação do dever de investigar na medida em que, sem uma investigação apropriada, o administrador jamais interviria em algum

\footnotetext{
${ }^{62}$ CAMPOS, Luiz Antonio de Sampaio. Deveres e Responsabilidades. In: LAMY FILHO, Alfredo; PEDREIRA, José Luiz Bulhões (Org.). Direito das Companhias. Rio de Janeiro: Forense, 2009. p. 1108. ${ }^{63}$ PARENTE, Flávia. O Dever de Diligência dos Administradores de Sociedades Anônimas. Rio de Janeiro: Renovar, 2005. p. 9.

${ }^{64}$ RIBEIRO, Renato Ventura. Dever de diligência dos administradores de sociedades. São Paulo: Quartier Latin, 2006. p. 229.
} 
assunto, pois não saberia sequer da necessidade de uma intervenção. Dessa maneira, quando constatar uma red flag, o administrador deverá estudá-la e, dependendo do caso, intervir.

De acordo com CAMPOS:

Quando constatar algum indício de irregularidade, o que pode se dar não só mediante atuação na operação específica, mas também, sem precipitação, por meio da convocação de Reunião da Diretoria, do Conselho de Administração, Assembleia Geral ou Conselho Fiscal, conforme a discricionariedade do administrador, ou da cientificação desses órgãos a respeito do corrido ${ }^{65}$.

Vale mencionar, nesse sentido, que o Colegiado da CVM, por maioria de votos, já entendeu que, em hipóteses excepcionais, o dever de intervir pode se estender até mesmo perante terceiros. Assim se deu no Processo Administrativo Sancionador CVM nº RJ2007/4476, conhecido como o caso Felícia. Conforme o voto vencedor do diretor Marcos Barbosa Pinto:

Como se vê, não se encontra na Lei $n^{\circ}$ 6.404/76 nenhum dispositivo que dê amparo à afirmação, implícita na acusação, de que um membro do conselho de administração não pode se opor, perante terceiros, a uma decisão tomada pelos demais conselheiros, ainda mais se essa deliberação é, na sua opinião, ilegal ${ }^{66}$.

${ }^{65}$ CAMPOS, Luiz Antonio de Sampaio. Deveres e Responsabilidades. In: LAMY FILHO, Alfredo; PEDREIRA, José Luiz Bulhões (Org.). Direito das Companhias. Rio de Janeiro: Forense, 2009. p. 1110. ${ }^{66}$ Processo Administrativo Sancionador CVM nº RJ2007/4476, Rel. Eli Loria, j. em 12 mar. 2008. 


\section{CAPÍTULO 2 - A TOMADA DE DECISÃO}

A principal tarefa dos administradores de companhias é tomar decisões. A decisão, seja ela organizacional (que busca a boa organização interna da companhia), seja ela negocial (que tem como principal fim o lucro), é intrínseca à atividade de administração de empresas.

Não obstante, como se verá no Capítulo 4 desta monografia, a tomada de decisão é o principal foco de análise dos tribunais norte-americanos quando da aplicação da business judgment rule. Por essa regra, é o processo decisório perseguido pelo administrador que definirá se ele deverá ou não ser responsabilizado pela má fortuna de um negócio.

Sendo assim, visando a melhor compreender esse processo, mas sem a intenção de esgotar o tema - o que fugiria do escopo do presente trabalho -, este capítulo apresentará os elementos básicos de toda decisão, com foco especial naquelas que têm como objetivo final a consecução de lucros.

Com isso, busca-se evidenciar a comunicação existente entre a ciência da administração de empresas e o Direito, na medida em que o fato social sobre o qual a norma jurídica (no caso, a business judgment rule) será aplicada será melhor entendido.

Compreender-se-á, ao menos em parte, os fundamentos econômicos que envolvem a tomada de decisão, visualizando-se com maior clareza o motivo pelo qual resguardar administradores de qualquer responsabilidade por conta de uma decisão honesta é tão relevante para a economia de um país.

Primeiramente, serão analisados o conceito de decisão, a situação na qual ela será necessária para solucionar um problema e a constante presença de risco, incerteza e complexidade, de modo a inferir-se como esses elementos interferem no juízo de um administrador. 
Em seguida, demonstrar-se-á que, embora possam ser considerados fatores negativos para o bom resultado de um negócio, a tomada de riscos e a atuação sob incerteza são essenciais para que se possa vislumbrar o lucro. Fundamenta-se, com isso, o argumento de que administradores devem agir sob essas condições e não podem ser por isso responsabilizados.

Por fim, o estudo da Teoria dos Jogos demonstrará que o administrador, uma vez inserido em um mercado competitivo, não está sujeito aos efeitos exclusivamente adstritos à sua decisão, mas também à decisão de outros agentes do mercado, sejam eles concorrentes, parceiros comerciais ou consumidores.

Dessa forma, uma vez compreendido o cenário em que se dá a tomada de decisão de administradores de sociedades anônimas, a análise das normas jurídicas que regem tal atividade se dará de forma mais lúcida e consciente.

\subsection{Decisão}

Decisão é a escolha de uma dentre as diversas alternativas de ação que surgem para a resolução de problemas. Conforme MONTEIRO GOMES e SIMÕES GOMES, “um processo de tomada de decisão pode conceber-se como a eleição por parte de um centro decisor - um indivíduo ou um grupo de indivíduos - da melhor alternativa entre as possíveis"67.

No contexto econômico, TORRES JUNIOR e MOURA afirmam que "tomar decisão é alocar irreversivelmente recursos. Irreversível porque, uma vez alocados os recursos, reverter a decisão sempre envolverá perdas. Um caminho de ação se iniciou e o tempo é certamente irreversível"68.

Nessa linha, é importante se ter em mente que não há decisões certas ou erradas do ponto de vista econômico. Há, na verdade, decisões que alcançam o

\footnotetext{
${ }^{67}$ MONTEIRO GOMES, Luiz Flavio Autran; SIMÕES GOMES, Carlos Francisco. Tomada de Decisão Gerencial: Enfoque Multicritério. $4^{\mathrm{a}}$ ed. São Paulo: Atlas, 2012. p. 1.

${ }^{68}$ TORRES JUNIOR, Alvair Silveira; MOURA, Gilnei Luiz de. Decisão em Administração - uma discussão. In: YU, Abraham Sin Oih. Tomada de Decisão nas Organizações. São Paulo: Saraiva, 2011. p. 4
} 
fim pretendido e decisões que não o alcançam. "Em outras palavras, a qualidade da decisão tomada no passado é julgada com fundamento em suas consequências no presente"

EISENBERG bem ilustra esse entendimento:

For example, an executive faced with a promising but expensive and untried new technology may have to choose between investing in the technology or forgoing such an investment. Each alternative involves certain negative risks. If the executive chooses one alternative and the associated negative risk materializes, the decision is "wrong" in the very restricted sense that if the executive had it to do all over again he would make a different decision, but it is not a bad decision. Under a reasonableness standard of review, however, factfinders might too often erroneously treat decisions that turned out badly as bad decisions, and unfairly hold directors and officers liable for such decisions ${ }^{70}$.

Sendo assim, a finalidade do estudo de decisões tomadas no passado é verificar o motivo pelo qual certa decisão alcançou ou não o seu objetivo. Não se estuda, portanto, se a decisão foi certa ou errada. É o que escreve ABRAMCZUK:

O interesse é identificar - em termos de normas de racionalidade - as causas das quais resultaram as consequências adversas e obter informações que contribuam para aperfeiçoar o processo de decisão para um número indeterminado de situações futuras $(\ldots)^{71}$.

\subsection{Problema}

Toda decisão é a solução de um problema ${ }^{72}$. Este, por sua vez, é a necessidade de se optar por uma dentre diversas ações possíveis diante de uma situação específica. De acordo com ABRAMCZUK, "existe problema somente quando uma situação suscita em alguém a necessidade de agir e, para agir, este alguém deve escolher uma ação dentre várias possíveis"73.

Situação, explica o autor, é o resultado de uma afirmação sobre uma realidade, que pode se dar na forma de relato sobre um fato ou como uma

\footnotetext{
${ }^{69}$ ABRAMCZUK, André A. A Prática da Tomada de Decisão. São Paulo: Atlas, 2009. p. 30.

${ }^{70}$ EISENBERG, Melvin Aron. The Divergence of Standards of Conduct and Standards of Review in Corporate Law. Fordham Law Review. vol. 62, 1993, p. 444.

${ }^{71}$ ABRAMCZUK, André A. A Prática da Tomada de Decisão. São Paulo: Atlas, 2009. p. 30.

${ }^{72}$ A palavra problema tem sua origem no grego. Trata-se de substantivo derivado do verbo proballein, uma junção de pro, que significa adiante, em frente, e ballein, que significa lançar, atirar. Seu significado literal, portanto, é ato ou efeito de lançar em frente (Ibid., p. 1).

${ }^{73}$ Ibid., p. 1-2.
} 
suposição a respeito de algum aspecto de uma realidade ${ }^{74}$. Ação, por sua vez, seria um "comportamento consciente, manifestado pelo emprego deliberado de meios para atingir determinado fim, alcançar um objetivo"75.

Assim, nos dizeres de BINMORE, pode-se demonstrar um problema "as a function $\mathrm{D}: \mathrm{A} \times \mathrm{B}=\mathrm{C}$ in which $\mathrm{A}$ is the set of available actions, $\mathrm{B}$ the set of possible states of the world, and $\mathrm{C}$ is the set of possible consequences"76.

Como exemplo de um problema, tem-se o administrador de companhia aberta que, diante da necessidade de captação de recursos volumosos em pouco tempo (situação), deve escolher entre realizar oferta pública ou privada de valores mobiliários (ações possíveis). Ou o caso em que, diante de lançamentos de produtos fortemente competitivos por parte da concorrência (situação), um administrador deve decidir entre investir em inovação ou procurar outros mercados (ações possíveis).

Nesses cenários, há um universo de possíveis consequências para cada ação tomada, sendo o problema solucionado com "uma ação que contribui para eliminar ou atenuar uma situação de insatisfação ou desconforto presente" ou, ainda, "prevenir uma situação antevista como causa de insatisfação ou desconforto no futuro"77.

\subsection{Risco, incerteza e complexidade}

Em seu estudo sobre o processo de tomada de decisões, ABRAMCZUK constata que as formas de se analisar alternativas de ação mais adequadas para se resolver um problema estão condicionadas a dois fatores: incerteza e complexidade $^{78}$, sendo que risco, para esse autor, está inserido no conceito de incerteza.

\footnotetext{
${ }^{74}$ Ibid., p. 2.

75 Ibid., p.4.

${ }^{76}$ BINMORE, Ken. Rational Decisions. Princeton: Princeton University Press, 2009. p. 2. A letra $D$ utilizada pelo autor representa o termo decision problem.

77 ABRAMCZUK, André A. A Prática da Tomada de Decisão. São Paulo: Atlas, 2009. p. 11.

${ }^{78}$ Ibid., p. 12.
} 
Uma vez eleita a ação considerada a mais adequada para a solução de um problema, uma quantidade indeterminável de possíveis consequências pode tomar corpo.

Mesmo com o apoio de estudos previamente realizados, da análise de todas as probabilidades e da previsão de certas situações, nem sempre é possível determinar com antecedência todos os resultados de uma ação, a probabilidade de cada um deles e qual será a consequência final. Não há como se ter certeza, assim, de todo o andamento dos fatores de uma decisão.

A falta de certeza, no entanto, não se confunde com a existência de dúvida ou ignorância por parte do decisor. São conceitos distintos. Como explica ABRAMCZUK,

enquanto dúvida é a característica de uma condição que exige investigação e ignorância é basicamente ausência de conhecimento, incerteza é a incapacidade de determinar antecipadamente a ocorrência de eventos possíveis ${ }^{79}$.

Nesse sentido, o autor divide a incerteza em dois tipos: incerteza estatística (ou risco) e incerteza epistêmica.

Há incerteza estatística na medida em que se conhece a probabilidade de cada um dos possíveis resultados de uma ação ${ }^{80}$. Tem-se como exemplo o arremesso de uma moeda. Sabendo-se que ela possui apenas dois lados, é certo que há $50 \%$ de chances de o resultado ser cara ou coroa. Contudo, o resultado continua sendo incerto, na medida em que não há como se afirmar, com certeza, qual face da moeda cairá voltada para cima ${ }^{81}$.

A incerteza epistêmica, por sua vez, ocorre quando se desconhece não somente a distribuição de probabilidades dos possíveis resultados, mas também "todos os fatores que determinam um evento em especial, de tal modo que o

\footnotetext{
${ }^{79}$ Ibid., p. 12.

${ }^{80}$ Ibid., p. 12.

${ }^{81}$ Ibid., p. 12.
} 
mesmo evento, ocorrendo em diferentes tempos e lugares, não tem necessariamente as mesmas causas" $" 82$.

Há incerteza, nesse caso, sobre todos os aspectos de um determinado fato, não sendo possível determinar, com certeza, qualquer dos elementos que o compõe. Como exemplo, ABRAMCZUK cita a incerteza que se tem a respeito do futuro preço de um produto:

Como somente essas três condições definem todo o universo de probabilidades do preço do produto [o autor se refere às possibilidades de o preço futuro ser superior, igual ou inferior ao preço atual], a probabilidade deste universo é igual a 1 , ou $100 \%$, isto é, representando por $H$ a probabilidade de que o preço daqui a noventa dias seja superior ao de hoje, por $L$ a probabilidade de que seja inferior e por $E$ a probabilidade de que permaneça igual ao preço de hoje, então se sabe que $H+L+E=1$, mas os valores de $H, L$ e $E$ são desconhecidos; além disso, não se conhecem todos os fatores que determinarão o preço do produto daqui a noventa $\operatorname{dias}^{83}$.

Nessa classificação, ABRAMCZUK insere o conceito de risco como um tipo de incerteza - seria a incerteza estatística. Neste trabalho, contudo, a incerteza estatística será referida pelo termo risco, ao passo que incerteza se restringirá ao conceito de incerteza epistêmica.

Com isso em mente, é importante ressaltar que, apesar de comumente utilizados como sinônimos, o conceito de risco é diferente do conceito de incerteza. São termos distintos na medida em que, enquanto o primeiro se refere a situações nas quais ao menos as probabilidades de certo resultado são determináveis e mensuráveis, o segundo guarda relação com situações em que nem as probabilidades são quantificáveis. O resultado, neste caso, é, em termos estatísticos, plenamente incerto.

Nesse sentido, KNIGHT adverte o seguinte:

Uncertainty must be taken in a sense radically distinct from the familiar notion of Risk, from which it has never been properly separated. The term "risk", as loosely used in everyday speech and in economic discussion, really covers two things which, functionally at least, in their causal relations to the phenomena of economic organization, are categorically different. (...) The essential fact is that "risk" means in some cases a quantity susceptible of measurement, while at other times it is something

\footnotetext{
${ }^{82}$ Ibid., p. 12.

${ }^{83}$ Ibid., p. 13.
} 
distinctly not of this character; and there are far-reaching and crucial differences in the bearings of the phenomenon depending on which of the two is really present and operating. (...) It will appear that a measurable uncertainty, or 'risk' proper, as we shall use the term, is so far different from an unmeasurable one that it is not in effect an uncertainty at all. We shall accordingly restrict the term 'uncertainty' to cases of the non-quantitative type ${ }^{84}$.

BINMORE vai na mesma direção:

Pandora [personagem utilizado pelo autor em seus exemplos didáticos] makes a decision under risk if unambiguous probabilities can be assigned to the states of the world in her belief space B. (...) The archetypal case of risk is playing roulette in a casino. The archetypal case of uncertainty is betting at the race track. Who knows what the probability is that Punter's Folly will win? Does it even make sense to attribute a probability to such a one-off occurrence ${ }^{85}$ ?

O conceito de incerteza também é estudado por KEYNES. Ele segue KNIGHT e BINMORE, no sentido de que a incerteza não pode ser quantificada em termos probabilísticos:

By 'uncertain' knowledge, let me explain, I do not mean merely to distinguish what is known for certain from what is only probable. The game of roulette is not subject, in this sense, to uncertainty; nor is the prospect of a Victory bond being drawn. Or, again, the expectation of life is only slightly uncertain. Even the weather is only moderately uncertain. The sense in which I am using the term is that in which the prospect of a European war is uncertain, or the price of copper and the rate of interest twenty years hence, or the obsolescence of a new invention, or the position of private wealth owners in the social system in 1970 [deve-se considerar, aqui, que este trecho foi escrito em 1937]. About these matters there is no scientific basis on which to form any calculable probability whatever. We simply do not know ${ }^{86}$.

De acordo com o autor, as situações de incerteza se dão porque, em tais situações, as estimativas a respeito do futuro seriam baseadas em um conhecimento extremamente precário sobre os fatores que determinarão o futuro. Nesse sentido, KEYNES assim explica porque o rendimento de um investimento em alguns anos é imprevisível:

The outstanding fact is the extreme precariousness of the basis of knowledge on which our estimates of prospective yield have to be made. Our knowledge of the factors which

\footnotetext{
${ }^{84}$ KNIGHT, Frank H. Risk, uncertainty and profit. Londres: Houghton Mifflin, 1921. p. 20.

${ }^{85}$ BINMORE, Ken. Rational Decisions. Princeton: Princeton University Press, 2009. p. 35.

${ }^{86}$ KEYNES, John Maynard. The General Theory of Employment. The Quarterly Journal of Economics. February, 1937, v. 14, p. 113-114.
} 
will govern the yield of an investment some years hence is usually very slight and often negligible ${ }^{87}$.

Dessa forma, em conclusão, quando as probabilidades não puderem ser quantificadas, estar-se-á em situação de incerteza. O risco só estará presente nos casos em que seja possível determinar qual a probabilidade de ocorrência de uma das possíveis consequências de uma ação.

Outro fator condicionante da determinação da alternativa mais adequada para a solução de problemas trazido por ABRAMCZUK é a complexidade, que, segundo ele, "é termo que se aplica a sistemas que consistem em partes que interagem de tal modo que influenciam significativamente o estado ou comportamento do sistema no futuro" $"$.

Um sistema complexo apresenta determinadas propriedades que somente são alcançadas pela atuação conjunta de suas partes. Isoladas, nenhuma de suas partes possui tais propriedades ${ }^{89}$. O resultado esperado, portanto, não depende somente de um agente decisor.

Um exemplo trazido por ABRAMCZUK é o mercado eficiente, no qual atuam diversos compradores, fornecedores e especuladores, com informações e poder de barganha próprios. A propriedade desse sistema seria o equilíbrio de preços.

Vistos os conceitos de risco, incerteza e complexidade, tem-se que os dois primeiros condicionantes (risco e incerteza) são essenciais para que se possa almejar o lucro. É o que o item a seguir abordará.

\footnotetext{
87 KEYNES, John Maynard. The general theory of employment, interest and money. Londres: Macmillan, 1936. p. 149.

${ }^{88}$ ABRAMCZUK, André A. A Prática da Tomada de Decisão. São Paulo: Atlas, 2009. p. 13.

${ }^{89}$ Ibid., p. 13-14.
} 


\subsection{A relação necessária entre risco, incerteza e lucro}

Um dos principais pilares da business judgment rule é a intenção de se encorajar administradores a tomarem riscos (o que também inclui atuar sob incerteza). Isso se dá porque, sem risco, não há lucro.

Contudo, essa afirmativa (de que, sem risco, não há lucro), juntamente com a ideia de que os administradores devem ser ousados e inovar, vem sendo constantemente repetida sem uma fundamentação lógica que a confirme. É como se fosse uma verdade inquestionável.

Tendo isso em vista, este item tem como objetivo demonstrar porque os administradores - que se enquadram no conceito de agente econômico ${ }^{90}$, a ser utilizado com certa frequência daqui em diante - precisam ser ousados e inovar no exercício de suas funções para que a distribuição de dividendos aos acionistas seja possível. Reforçar-se-á, com fundamentos econômicos, o fato de que o risco e a atuação sob incerteza são realmente essenciais à obtenção de lucro.

Com isso, será mais simples compreender porque uma das razões da business judgment rule, como se estudará no Capítulo 4 deste trabalho, é o fato de que administradores precisam tomar riscos, não sendo coerente $o$ ordenamento jurídico criar obstáculos à ousadia desses profissionais.

Feitos esses esclarecimentos, passe-se ao exame da relação necessária entre risco, incerteza e lucro.

O principal objetivo de um agente econômico, ao iniciar um empreendimento, é a obtenção de lucro. Assim entendeu Adam Smith, como descrevem BERLE e MEANS:

For Adam Smith and his followers, it was possible to abstract one motive, the desire for personal profit, from all the motives driving men to action and to make this the key

\footnotetext{
${ }^{90}$ Uma vez que representam e conduzem uma companhia, sociedade empresária com forte atuação no mercado e constituída por acionistas que têm absoluto interesse em sua atividade lucrativa, não há óbices em referir-se aos administradores como agentes econômicos.
} 
to man's economic activity. They conclude that, where true private enterprise existed, personal profit was an effective and socially beneficent motivating force ${ }^{91}$.

O lucro é intrínseco à atividade empresária, definida, no direito brasileiro, pelo artigo 966 do Código Civil, como a "atividade econômica organizada para a produção ou a circulação de bens ou de serviços”. É o exercício da empresa, que, como explica CAMPINHO, "manifesta-se como uma organização técnicoeconômica, ordenando o emprego de capital e trabalho para a exploração, com fins lucrativos, de uma atividade produtiva"92.

Nesse sentido, o objetivo final de duas ou mais pessoas, ao se associarem para constituir uma sociedade empresária, é a obtenção de lucros, que ocorrerá por meio da geração de resultado e a consequente distribuição de dividendos. Assim explica FRANÇA:

Ora, qual é esse interesse comum que une os sócios, da fundação da sociedade à sua dissolução, no dizer de Mignoli? Trata-se do interesse à realização do escopo social, ou, se se preferir, de qualquer interesse que se insira no esquema causal do contrato de sociedade. Abrange, portanto, tanto o denominado escopo-meio, que é o exercício da empresa, considerada como objeto da sociedade (art. $2^{\circ}$ da Lei 6.404), como o escopofim, de produção e de distribuição de lucros entre os sócios, sob a forma de dividendos ${ }^{93}$.

Os agentes econômicos, para obterem sucesso em um mercado competitivo, devem sempre estudar as necessidades específicas de seus consumidores e oferecer o melhor produto pelo menor preço possível. Devem, também, com base nas informações que possuem no presente, explorar oportunidades que surgirem à sua frente, seja explorando novas ideias, seja buscando outros mercados ou criando novos produtos.

Entretanto, eles não são capazes de antecipar o estado futuro do mercado e, por isso, se sujeitam a fatores negativos como o risco e a incerteza. Mas, por mais paradoxal que possa parecer, essa sujeição é uma condição necessária para

\footnotetext{
${ }^{91}$ BERLE, Adolf A.; MEANS, Gardiner C. The Modern Corporation \& Private Property. New Brunswick: Transaction Publishers, 2009. p. 307.

${ }^{92}$ CAMPINHO, Sérgio. O Direito de Empresa à Luz do Novo Código Civil. $11^{\mathrm{a}}$ ed. Rio de Janeiro: Renovar, 2010. p. 11.

${ }^{93}$ FRANÇA, Erasmo Valladão Azevedo e Novaes. Conflito de Interesses nas Assembleias de S.A. São Paulo: Malheiros, 1993. p. 60.
} 
que haja lucro, pois, segundo KNIGHT, o lucro é resultado indireto de mudanças

no estado atual das coisas $^{94}$.

De acordo com ele, mudanças fazem com que, no futuro, valores, salários e rendas se diferenciem daqueles atuais. Citando a obra The Distribution of Wealth, de John Bates Clark, KNIGHT explica que mudanças dinâmicas são caracterizadas pelas invenções do homem - o que pode ser equiparado à inovação, termo frequentemente utilizado por obras literárias voltadas às ciências econômicas e de administração de empresas.

As invenções (ou inovações) fazem com que seja possível produzir um determinado produto de forma menos custosa, o que aumenta o lucro de empreendedores e, consequentemente, incrementa salários e rendas em uma comunidade. Nesse sentido, conforme DRUCKER,

Innovation is the specific function of entrepreneurship, whether in the existing business, a public institution, or a new venture started by a lone individual in the family kitchen. It is the means by which the entrepreneur either creates new wealth-producing resources or endows existing resources with enhanced potential for creating wealth ${ }^{95 / 96 / 97}$.

\footnotetext{
${ }^{94}$ KNIGHT, Frank H. Risk, uncertainty and profit. Londres: Houghton Mifflin, 1921. p. 34.

${ }^{95}$ DRUCKER, Peter F. The Discipline of Innovation. In: HBR's Ten Must Reads on Innovation. Boston: Harvard Business Review Press, 2013. p. 143.

${ }^{96} \mathrm{O}$ autor, em outra obra de sua autoria, complementa o conceito de inovação: "It is the act that endows resources with a new capacity to create wealth. Innovation, indeed, creates a resource. There is no such thing as a 'resource' until man finds a use for something in nature and thus endows it with economic value. Until then, every plant is a weed and every mineral just another rock. Not much more than a century ago, neither mineral oil seeping out of the ground nor bauxite, the ore of aluminum, were resources. They were nuisances; both render the soil infertile. The penicillin mold was a pest, not a resource. Bacteriologists went to great lengths to protect their bacterial cultures against contamination by it. Then in the 1920s, a London doctor, Alexander Fleming, realized that this 'pest' was exactly the bacterial killer bacteriologists had been looking for - and the penicillin mold became a valuable resource. The same holds just as true in the social and economic spheres. There is no greater resource in an economy than 'purchasing power'. But purchasing power is the creation of the innovating entrepreneur' DRUCKER, Peter F. Innovation and Entrepreneurship. Nova York: Harper, 1985. p. 30.

${ }^{97}$ Vale ressaltar, aqui, que um dos motivos pelos quais o crescimento do Brasil tem sido abaixo das expectativas se dá pela baixíssima capacidade de produção do país, o que está intimamente ligado à sua igualmente baixíssima capacidade de inovação. Assim apontam MENEZES FILHO e KANNEBLEY JUNIOR: "Conforme indicadores oferecidos pelo Ministério da Ciência, Tecnologia e Inovação (MCTI), o Brasil ocupa uma posição relativamente atrasada internacionalmente. Em 2009, os gastos com P\&D [pesquisa e desenvolvimento] no Brasil giravam em torno de $1,17 \%$ do PIB, enquanto países como Estados Unidos e Alemanha gastavam 2,9\% e 2,8\% do PIB, respectivamente. Os dispêndios relativos do Brasil são similares aos da Rússia (1,25\%) e Itália (1,26\%), mas inferiores aos da China (1,7\%) e Coreia (3,6\%), por exemplo. (...) Pesquisas recentes têm enfatizado a importância de gestão moderna para a inovação e o crescimento da produtividade. Estudos comparando as firmas brasileiras com as de outros países mostram que é bem pequena a proporção de firmas industriais brasileiras que adotam as práticas
} 
Sendo assim, veja-se, enfim, como KNIGHT bem descreve o processo acima exposto:

\begin{abstract}
"Obviously, from all these changes two general results must follow: first, values, wages and interest will differ from the static standards; secondly, the static standards themselves will always be changing." The type of dynamic change is invention: "an invention makes it possible to produce something more cheaply. It first gives a profit to entrepreneurs and then (...) adds something to wages and interest. (...) Let another invention be made. (...) It also creates a profit; and this profit, like the first, is an elusive sum, which entrepreneurs grasp but cannot hold." It "slips through their fingers and bestows itself on all members of society". Thus the effect of any one dynamic change is to produce temporary profits. But in actual society such changes may constantly occur, and the readjustments are always in process. "As a result, we (...) have the standard of wages moving continuously upward and actual wages steadily pursuing the standard rate in its upward movement, but always remaining by a certain interval behind it".

In another sense profit is dependent on "friction"; "The interval between actual wages and the static standard is the result of friction; for, if competition worked without let or hindrance, pure business profit would be annihilated as fast as it could be created (...)". "Were it not for that interval, entrepreneurs as such would get nothing, however much they might add to the world's productive power" $"$.
\end{abstract}

Contudo, o autor faz uma ressalva: não basta que mudanças ocorram para que o lucro seja possível, é necessário que elas não sejam uniformes e nem possam ser facilmente antecipadas, pois, caso o fossem, o mercado competitivo, prevendo as condições futuras, ajustaria seus elementos ao estado ideal, em que todos os preços se igualizariam aos seus correspondentes custos e, então, o lucro seria inexistente.

Isso porque, prevendo-se o que ocorrerá no futuro, as mudanças causadas pelas inovações já seriam antevistas e antecipadas. Com isso, todos os efeitos de tais mudanças seriam anulados, uma vez que não haveria tempo para o empreendedor obter lucro - quando a mudança chegar, o valor do bem já terá

mais avançadas de resolução de problemas, gerenciamento de recursos humanos, estabelecimento de metas e acompanhamento de resultados. Todos esses fatores fazem com que o crescimento da produtividade da nossa indústria de transformação tenha ficado muito aquém dos países mais desenvolvidos. MENEZES FILHO, Naercio; KANNEBLEY JUNIOR, Sérgio. Abertura Comercial, Exportações e Inovações no Brasil. In: VELOSO, Fernando; FERREIRA, Pedro Cavalcanti; GIAMBIAGI, Fabio; PESSÔA, Samuel. Desenvolvimento Econômico: uma Perspectiva Brasileira. Rio de Janeiro: Elsevier, 2013. p. 417-419.

${ }^{98}$ KNIGHT, Frank H. Risk, uncertainty and profit. Londres: Houghton Mifflin, 1921. p. 34-35. 
sofrido a mesma redução que os seus custos de produção. Assim, um anulará o outro, não havendo lucro nem prejuízo.

\section{Assim adverte KNIGHT:}

The fatal criticism of this procedure of taking changes in conditions as the explanation and cause of profit is that it overlooks the fundamental question of the difference between a change that is foreseen a reasonable time in advance and one that is unforeseen. Now, if we merely assume that all the "dynamic changes" which Professor Clark enumerates, and any others which may be named, are foreknown for a sufficient time before they take place, or that they take place continuously in accordance with laws generally and accurately known, so that their course may be predicted as far into the future as occasion may require, then the whole argument based on the effects of change will fall completely to the ground ${ }^{99}$.

\section{Continua:}

Some changes are foreseen and some are not, the laws of some are tolerably accurately known, of others hardly at all; and the variation in foreknowledge makes it clearly indispensable to separate its effects from those of change as such if any real understanding of the elements of the situation is to be attained.

(...)

No a priori argument is necessary to prove that with general foreknowledge of progressive changes no losses and no chances to make profits will arise out of them. This is the first principle of speculation, and is particularly familiar in the capitalization of the anticipated increase in the value of land. The effect of any chance which can be foreseen will be adequately discounted in advance, any "costs" connected with it will be affected in exactly the same way as the corresponding "values" and no separation between the two will take place ${ }^{100}$.

\section{E conclui:}

It cannot, then, be change, which is the cause of profit, since if the law of the change is known, as in fact is largely the case, no profits can arise. The connection between change and profit is uncertain and always indirect. Change may cause a situation out of which profit will be made, if it brings about ignorance to the future. Without change of some sort there would, it is true, be no profits, for if everything moved long in an absolutely way, the future would be completely foreknown in the present and competition would certainly adjust things to the ideal state where all prices would equal costs.

(...)

It is not dynamic change, nor any change, as such, which causes profit, but the divergence of actual conditions from those which have been expected and on the basis of which business arrangements have been made ${ }^{101}$.

\footnotetext{
${ }^{99}$ Ibid., p. 35.

100 Ibid., p. 35-36.

101 Ibid., p. 37.
} 
Portanto, como bem aponta IORIO DE SOUZA, "a fonte principal do lucro é exatamente a incapacidade de todos os empresários, ao mesmo tempo, anteciparem corretamente o estado futuro do mercado" ${ }^{102}$. Em outras palavras, ao visarem ao lucro, os agentes econômicos devem necessariamente se aventurar em situações de risco e incerteza.

Mas é importante ressalvar, aqui, que não se quer dizer que os lucros serão certos se agentes econômicos tomarem riscos ou agirem sob incerteza ${ }^{103}$. Pretende-se, sim, destacar o fundamento de que o lucro não é possível se o risco ou a incerteza não forem encarados.

Frise-se: mantendo-se inerte e alheio aos riscos e incertezas do mercado, o agente não verá o desenvolvimento de seus negócios e, em última análise, da sociedade civil. O resultado de um comportamento estático, então, seria negativo para todos.

Trata-se de um movimento encadeado. Se não inovar, o agente econômico não será capaz de criar recursos e diminuir seus custos. Assim, dificilmente lucrará com a sua atividade. Sem isso, a sociedade civil não verá desenvolvimento algum.

Mas a inovação não é a única maneira de se manter fora da inércia, arriscar e buscar o desenvolvimento. Muitas vezes, para desenvolver certo negócio, é necessário que se realize aquisições, busque novos mercados, trace estratégias

102 IORIO DE SOUZA, Ubiratan Jorge. Economia e Liberdade: A Escola Austríaca e a Economia Brasileira. São Paulo: Editora Inconfidentes, 1995. p. 77.

${ }^{103}$ A esse respeito, vale mencionar que, quanto mais longe for, mais arriscada e incerta será a decisão do agente econômico, assim como serão maiores suas chances de prejuízo, já que a probabilidade de se obter o resultado esperado será cada vez menor ou mais desconhecida. Nessa linha, MCGRATH e MACMILLAN apontam casos em que grandes companhias, com vasta experiência e consagradas pelo mercado, sofreram com grandes perdas ao adentrarem territórios desconhecidos: "Business lore is full of stories about smart companies that incur huge losses when they enter unknown territory - new alliances, new markets, new products, new technologies. The Walt Disney Company's 1992 foray into Europe with its theme park had accumulated losses of more than $\$ 1$ billion by 1994. Zapmail, a fax product, cost Federal Express Corporation $\$ 600$ million before it was dropped. Polaroid lost $\$ 200$ million when it ventured into instant movies. Why do such efforts often defeat even experienced, smart companies? One obvious answer is that strategic ventures are inherently risky: the probability of failure simply comes with the territory" MCGRATH, Rita Gunter; MACMILLAN, Ian C. Discovery-Driven Planning. In: HBR's Ten Must Reads on Innovation. Boston: Harvard Business Review Press, 2013. p. 125. 
agressivas de competitividade etc. Essas medidas, contudo, são igualmente arriscadas e seus resultados nunca serão integralmente previsíveis.

Nesse sentido, em seu estudo a respeito de falhas de grandes administradores, FINKELSTEIN aponta que, além da inovação, há outros três fatores que, igualmente arriscados e incertos, podem levar companhias ao prejuízo:

When we considered all of the companies together, we realized that most of them failed during four major business passages: creating new ventures, dealing with innovation and change, managing mergers and acquisitions, and addressing new competitive pressures $^{104}$.

O autor justifica isso pelo fato de que esses eventos são muito complexos e envolvem um grau considerável de transformação - onde, lembre-se, residem o risco e o lucro: "These are multifaceted events that involve some degree of corporate transformation, and are very complex, so it's probably not that surprising that we find these stages of business specially perilous"105.

Diante disso, confirma-se e fundamenta-se o entendimento de que, se o administrador não enfrentar riscos ou incertezas, sua companhia jamais lucrará. Os acionistas que o elegeram, tendo em vista que possuem como principal objetivo a distribuição do máximo de dividendos possível, esperam dele uma atuação pouco conservadora.

Sendo assim, o regime de responsabilidades dos administradores deve ser cauteloso ao ponto de não criar um contrassenso na atividade desses profissionais. Isto é, se o ambiente econômico em que atuam os administradores exige deles que tomem decisões ousadas, não seria coerente o ordenamento jurídico responsabilizá-los por erros cometidos de forma honesta.

Com base nisso, verifica-se que, quando da elaboração da business judgment rule, os tribunais norte-americanos reconheceram que a atividade

\footnotetext{
${ }^{104}$ FINKELSTEIN, Sydney. Why Smart Executives Fail. Nova York: Portfolio, 2003. p. 16.

105 Ibid., p. 16.
} 
econômica, uma vez que tem como principal fim o lucro, é arriscada por natureza.

\subsection{Teoria dos Jogos}

Em um mercado competitivo, múltiplos agentes atuam em conjunto e, naturalmente, a escolha de um afeta a escolha de outro. Dessa forma, a estratégia traçada por cada agente deve levar em conta não somente as suas condições e as do mercado, mas também a posição a ser tomada por seus oponentes, o que dificulta, em um nível considerável, o sucesso de uma decisão negocial.

Assim, os resultados de uma decisão muitas vezes não refletem exclusivamente a conduta do agente econômico. Isto é, mesmo ele tendo sido amplamente diligente e tendo estudado de todas as formas possíveis a decisão que estava prestes a tomar, é possível que tudo dê errado apenas por conta do movimento de um concorrente.

Portanto, além de todos os riscos e incertezas que envolvem a tomada de decisão, a atuação de concorrentes é outro fator que pode levar companhias a prejuízos.

Uma vez que recursos são escassos, o sucesso ilimitado de todos os agentes de um mercado é impossível. Nessa direção, por mais estudada e refletida que possa ser, uma decisão pode dar errado simplesmente por conta da atuação de outros agentes.

Diante disso, este tópico visa, em primeiro lugar, a possibilitar uma maior compreensão a respeito da atividade dos administradores quando inseridos em um ambiente de competição. Com isso, a correlação entre o fato social e a norma jurídica que o regula (respectivamente, a tomada de decisão e o regime jurídico de responsabilização dos administradores - mais especificamente, a business judgment rule) será melhor destacada, sendo possível concluir, ao final deste trabalho, se são ou não compatíveis entre si. 
Em segundo, busca-se reforçar a consciência de que são inúmeros os fatores que levam uma atividade empresarial ao prejuízo, sendo a culpa do administrador apenas um deles. Melhores performances de concorrentes são somente um exemplo do que pode levar uma companhia ao fracasso sem que o administrador nada possa fazer.

Assim, visando a compreender a interação entre as decisões tomadas por agentes econômicos, VON NEUMANN e MORGENSTERN desenvolveram a ferramenta matemática conhecida como Teoria dos Jogos e a expuseram na obra Theory of Games and Economic Behavior, que será brevemente estudada neste item $^{106}$.

\subsubsection{O conceito de jogo e o objetivo da Teoria dos Jogos}

De acordo com BINMORE, "a game arises when several players have to make decisions in a situation in which the outcome for each player is partly determined by the choices made by the other players"107. Em outras palavras, estar-se-á diante de um jogo quando o resultado da decisão de um jogador ${ }^{108}$ for influenciado pelas decisões dos outros jogadores.

POUNDSTONE, por sua vez, escreve que o estudo da Teoria dos Jogos se dá em um cenário em que jogadores perfeitamente racionais estão interessados

\footnotetext{
106 Sobre a origem do estudo da Teoria dos Jogos, vale trazer o que escrevem PINHEIRO e SADDI: “A primeira tentativa formal de criar uma Teoria dos Jogos foi feita pelo matemático húngaro Jancsi Von Neumann, em 1928, em um artigo seminal intitulado 'Zur Theorie de Gesellschaftspiele', no qual desenvolve o conceito de interdependência estratégica. Em 1921, o matemático francês Émile Borel já havia publicado estudos sobre 'la théorie du jeu' e, depois, como ministro da Marinha francesa, continuara a pesquisar que tipo de jogo resultaria numa estratégia naval mais eficiente; no entanto, seu interesse se limitava à aplicação bélica. Daí porque se entende que foi realmente Von Neumann quem deu o status acadêmico à teoria, ainda que fosse apenas uma teoria matemática.

A Teoria dos Jogos, como um paradigma para entender e propiciar a tomada de decisões, não se tornaria popular até a Segunda Guerra Mundial, quando os ingleses se valeram desse instrumental para aumentar suas chances de atingir os submarinos alemães. Em 1944, Von Neumann e um economista da Universidade de Princeton, Oskar Morgenstern, publicaram Teoria dos Jogos e comportamento econômico, considerado o primeiro trabalho acadêmico sobre a teoria em foco" PINHEIRO, Armando Castelar; SADDI, Jairo. Direito, Economia e Mercados. Rio de Janeiro: Elsevier, 2005. p. 161-162. ${ }^{107}$ BINMORE, Ken. Rational Decisions. Princeton: Princeton University Press, 2009. p. 25.

108 Apenas para compatibilizar o restante do texto com o termo jogo, a expressão jogador será utilizada neste item para representar a figura do agente econômico atuante em um mercado competitivo.
} 
apenas em ganhar: "Game theory is about perfectly logical players interested only in winning"109/110.

Nesse sentido, ainda de acordo com POUNDSTONE:

The players are assumed to have perfect understanding of the rules and perfect memory of past moves. At all points in the game they are aware of all possible logical ramifications of their moves and their opponents' moves ${ }^{111}$.

Seguindo essa lógica, BINMORE ensina que o objetivo da Teoria dos Jogos é deduzir como os jogadores decidirão agir em um cenário tido como um jogo: "the traditional aim of a game-theoretic analysis is to deduce how players will choose when playing a game against each other from how they each individually play games against nature"112.

A esse respeito, vale citar, ainda, trecho de PINHEIRO e SADDI que bem resume o acima tratado:

Quando dois (ou mais) indivíduos interagem e suas ações se baseiam naquilo que esperam ou desejam que os outros façam, existe o que se denomina "comportamento estratégico". Quando isso ocorre, a interação entre eles pode ser tratada como um jogo. Em tal situação, a Teoria dos Jogos analisa e ajuda a prever as estratégias racionais desses indivíduos a partir da definição de quais são as regras do jogo. Os estudiosos de Direito \& Economia utilizam a Teoria dos Jogos para estudar como as empresas interagem, dadas as normas legais, e para entender como elas influenciam seu comportamento estratégico, como agentes econômicos ou como partes em litígios de diversos tipos ${ }^{113}$.

Visto o conceito de jogo e a que se presta a Teoria dos Jogos, passe-se ao exame de dois aspectos dessa teoria que têm forte incidência sobre a administração de companhias: o dilema do prisioneiro e o equilíbrio de Nash.

\footnotetext{
${ }^{109}$ POUNDSTONE, William. Prisoner's Dilemma. Nova York: Anchor, 1993. p. 44.

${ }^{110}$ Quanto a esse ponto, o próprio autor ressalva que a racionalidade perfeita é uma ficção: "Perfect rationality, like perfect anything, is a fiction. There's no such a thing as a perfectly straight line” Ibid., p. 44.

${ }^{111}$ Ibid., p. 44.

112 Ibid., p. 25.

113 PINHEIRO, Armando Castelar; SADDI, Jairo. Direito, Economia e Mercados. Rio de Janeiro: Elsevier, 2005. p. 157.
} 


\subsubsection{O dilema do prisioneiro: a estratégia dominante nem sempre leva ao melhor resultado}

Dilema, de acordo com PINHEIRO e SADDI, é a "apresentação de um dado problema que impõe uma decisão difícil ao final" ${ }^{114}$. Para eles, "o dilema não tem uma única solução, tampouco respostas precisas, mas desafia o raciocínio numa equação difícil de múltiplas escolhas"115.

O dilema do prisioneiro é um jogo entre dois agentes em que a polícia, após capturar dois suspeitos de um crime, os prende em celas diferentes, sem possibilidade de comunicação alguma. Com dificuldades em produzir provas contundentes para resolver o caso, a polícia propõe aos prisioneiros o seguinte cenário: se os dois se acusarem, serão eles indiciados a dois anos de prisão; se um acusar e o outro não, o que acusou será solto, ao passo que o acusado será indiciado a três anos de prisão; por fim, se nenhum acusar, serão ambos indiciados a um ano.

Considerando que os dois prisioneiros sabem que as mesmas condições foram propostas a ambos, a tabela seguinte descreve o dilema com o resultado para cada ação tomada em conjunto ${ }^{116}$ :

\begin{tabular}{|l|c|c|}
\cline { 2 - 3 } \multicolumn{1}{c|}{} & Prisioneiro B acusa & Prisioneiro B não acusa \\
\hline Prisioneiro A acusa & 2 anos/2 anos & Solto/3 anos \\
\hline $\begin{array}{l}\text { Prisioneiro A não } \\
\text { acusa }\end{array}$ & 3 anos/solto & 1 ano/1 ano \\
\hline
\end{tabular}

114 PINHEIRO, Armando Castelar; SADDI, Jairo. Direito, Economia e Mercados. Rio de Janeiro: Elsevier, 2005. p. 172.

115 Ibid., p. 172.

116 Ibid., p. 173. 
Pela análise dos dados desse jogo, a estratégia mais conservadora é acusar, pois assim não há chances de ser indiciado a três anos de prisão, a maior pena do caso. Como explicam PINHEIRO e SADDI,

se o comportamento for estritamente racional (e não é), ambos os criminosos terão penas de dois anos, uma vez que o mais "seguro" é acusar o outro e confessar o crime, na expectativa de que ele fará a mesma coisa ${ }^{117}$.

Contudo, o melhor resultado possível seria acusar e contar com a não acusação por parte do outro prisioneiro. Dessa forma, o que acusou seria solto, ao passo que o outro seria indiciado a três anos de prisão. Mas os dois podem pensar isso ao mesmo tempo e decidirem se acusar reciprocamente, chegando ao segundo pior resultado: dois anos de prisão.

Portanto, a melhor saída seria a cooperação entre os dois prisioneiros, em que nenhum deles acusa e ambos são indiciados a apenas um ano de prisão. Seria esse o segundo melhor resultado. Mas isso, obviamente, só seria possível se eles pudessem se comunicar. É o que observam PINHEIRO e SADDI:

\footnotetext{
Uma variação desse jogo é permitir que, em um dado momento, os prisioneiros possam se comunicar. Aqui o que se descobre é o grau de confiança no acordo entre um e outro. Os dois, racionalmente, podem combinar de não se acusar e, assim, garantir a menor pena. Entretanto, o que se pode imaginar é que haverá a quebra do acordo. Para os dois, a melhor estratégia, qualquer que seja a atitude do outro, é acusar (descumprindo a promessa), e o resultado de equilíbrio racional é a decisão mútua $(\ldots)^{118}$.
}

Diante disso, mostra-se que a estratégia dominante, ou seja, "o comportamento de um dos jogadores que lhe permite auferir uma recompensa maior (...), qualquer que seja a estratégia adotada pelo outro jogador"119, "nem sempre leva à melhor situação final" 120 .

Isso porque, se ignorar a estratégia de seu oponente, o jogador, no lugar de conseguir o melhor resultado possível, poderá obter o pior deles. A estratégia traçada, então, deve sempre levar em conta a estratégia do outro jogador, ainda que isso signifique abdicar da melhor recompensa.

\footnotetext{
117 Ibid., p. 173

118 Ibid., p. 174.

${ }^{119}$ Ibid., p. 176.

${ }^{120}$ Ibid., p. 176.
} 
Feita essa explanação, é importante ressaltar que o dilema dos prisioneiros é plenamente aplicável à atividade econômica das sociedades anônimas e, portanto, de seus administradores, sendo mais um auxílio à análise da tomada de decisão.

Nesse sentido, ainda que adotem a melhor estratégia, é possível que os administradores não alcancem o melhor resultado possível. Ou seja, mesmo tendo estudado todas as possibilidades de ação, todos os possíveis resultados de cada decisão, as probabilidades de perda etc., é possível que o ganho obtido seja menor do que o esperado.

É o que demonstram DILIX e NALEBUFF, ao ilustrarem um hipotético jogo entre a Coca-Cola e a Pepsi:

The prisoners' dilemma has applications to economics and business. Consider two firms, say Coca-Cola and Pepsi, selling similar products. Each must decide on a pricing strategy. They best exploit their joint market power when both charge a high price; each makes a profit of $\$ 10$ million per month. If one sets a competitive low price, it wins a lot of consumers away from the rival. Suppose its profit rises to $\$ 12$ million, and that of the rival falls to $\$ 7$ million. If both set low prices, the profit of each is $\$ 9$ million. Here, the low-price strategy is akin to the prisoner's confession [não acusar], and the high-price akin to keeping silent [acusar]. Call the former cheating, and the latter cooperation. Then cheating is each firm's dominant strategy, but the result when both "cheat" is worse for each than that of both cooperating ${ }^{121}$.

Assim, demonstra-se novamente que o bom resultado econômico da companhia em determinada situação não depende somente da vontade de seu administrador. A lógica em não se responsabilizar administradores por decisões honestamente erradas revela-se, nesse ponto, outra vez adequada à atividade desses profissionais.

\subsubsection{O equilíbrio de Nash}

Analisando a obra de VON NEUMANN e MORGENSTERN, NASH aponta que uma das teorias formuladas pelos autores seria a teoria dos jogos de $n$ pessoas do tipo cooperativo (em suas palavras, "theory of n-person games of a type which we would call cooperative"122). Segundo ele, "this theory is based

${ }^{121}$ DIXIT, Avinash; NALEBUFF, Barry. Prisoners' Dilemma. Fortune Encyclopedia of Economics. Nova York: Warner Books. p. 62.

${ }^{122}$ NASH, John. Non-Cooperative Games. The Annals of Mathematics. vol. 54. nº 2. set. 1951. p. 286. 
on an analysis of the interrelationships of the various coalitions which can be formed by the players of the game"123.

Ou seja, essa teoria leva em conta que os agentes de um jogo, quando não estiverem incomunicáveis, como no caso do dilema do prisioneiro, sempre buscarão firmar um acordo para chegarem à solução ótima. NASH, contudo, formulou uma teoria que vai no sentido contrário, baseada no fato de que agentes não realizam acordos e nem se comunicam:

our theory, in contradistinction, is based on the absence of coalitions in that it is assumed that each participant acts independently, without collaboration or communication with any of the others $^{124}$.

De acordo com PINHEIRO e SADDI,

Nash (...) partiu de um paradigma totalmente diferente: (...) a solução de um negócio depende de os jogadores perseguirem suas estratégias e seus interesses; porém, mesmo assim, para que a transação se realize, não basta que ela gere um excedente, é preciso haver também uma divisão adequada desse excedente ${ }^{125}$.

Dessa forma, NASH tem como principal fator para sua teoria a noção de ponto de equilíbrio ${ }^{126}$. E, como observa BINMORE, tal equilíbrio será alcançado se os dois jogadores escolherem, ao mesmo tempo, a estratégia que melhor responda à estratégia adotada por seu oponente ${ }^{127 / 128}$.

\section{Assim também ensina FIANI:}

Diz-se que uma combinação de estratégias constitui um equilíbrio de Nash quando cada estratégia é a melhor resposta possível às estratégias dos demais jogadores, e isso é verdade para todos os jogadores ${ }^{129}$.

\footnotetext{
123 Ibid., p. 286.

${ }^{124}$ Ibid., p. 286.

125 PINHEIRO, Armando Castelar; SADDI, Jairo. Direito, Economia e Mercados. Rio de Janeiro: Elsevier, 2005. p. 177.

${ }^{126}$ NASH, John. Non-Cooperative Games. The Annals of Mathematics. vol. 54. $\mathrm{n}^{\circ}$ 2. set. 1951. p. 286.

${ }^{127}$ BINMORE, Ken. Rational Decisions. Princeton: Princeton University Press, 2009. p. 26.

${ }^{128}$ No mesmo sentido, PINHEIRO e SADDI: "No equilíbrio de Nash, a solução é tal que nenhum jogador deseja mudar a sua estratégia, desde que os demais jogadores tampouco mudem as suas. É neste sentido que as estratégias individuais e a solução são ótimas, e que há um equilíbrio" PINHEIRO, Armando Castelar; SADDI, Jairo. Direito, Economia e Mercados. Rio de Janeiro: Elsevier, 2005. p. 177.

${ }^{129}$ FIANI, Ronaldo. Teoria dos Jogos: com aplicações em economia, administração e ciências sociais. $3^{\text {a }}$ ed. Rio de Janeiro: Elsevier, 1009. p. 93. Grifos do autor.
} 
Em outras palavras, haverá um equilíbrio quando ambos os jogadores tiverem adotado a melhor estratégia diante daquela adotada por seu oponente. Nesse sentido, as estratégias de ambos se moldam gradualmente até que, em dado momento, chegam a um equilíbrio, em que qualquer mudança poderá fazer com que um jogador ceda à estratégia do outro. A esse equilíbrio dá-se o nome de equilíbrio de Nash.

Um jogo, contudo, pode ter mais de um equilíbrio de Nash. A esse respeito, PINHEIRO e SADDI trazem o exemplo de uma relação entre uma produtora de autopeças e uma montadora de automóveis que compra as peças da produtora. Para a produção de um item, a produtora de autopeças pode produzir uma peça sob medida, o que seria benéfico à montadora, mas desde que esta adapte seu processo produtivo ${ }^{130}$.

Há, aqui, dois equilíbrios: se as duas sociedades investirem em tecnologia para se adaptarem uma à outra, as duas ganham. Se não houver investimento por parte de nenhuma delas, nada muda. O caso é melhor descrito por PINHEIRO e SADDI:

As adaptações nas duas empresas, para produzir e utilizar o componente feito sob medida, exige investimentos, mas a economia de custos daí resultante é suficiente para pagar por esse investimento e ainda gerar um excedente que pode ser dividido em partes iguais entre as empresas envolvidas.

Neste jogo, cada empresa tem duas opções: investir ou não na tecnologia. (...) Se os dois investem, os dois ganham. Se nenhum dos dois investe, nada muda. Se um investe, mas o outro não, há uma perda para quem investe porque, na ausência do investimento do outro, o dinheiro investido se perde ${ }^{131}$.

Como visto, então, pela teoria de Nash, os jogadores, visando aos seus próprios interesses, adotarão estratégias que, levando em conta o comportamento de seus oponentes, os levarão ao melhor resultado possível, mas sem necessariamente haver qualquer tipo de comunicação. Uma vez alcançado tal resultado, estabelecer-se-á um equilíbrio e os jogadores não buscarão alternativas melhores.

${ }^{130}$ PINHEIRO, Armando Castelar; SADDI, Jairo. Direito, Economia e Mercados. Rio de Janeiro: Elsevier, 2005. p. 181.

131 Ibid., p. 181. 
Assim como o dilema do prisioneiro, o equilíbrio de Nash ajuda a compreender que o melhor resultado a ser auferido em um jogo não é o mesmo que aquele em uma situação na qual o agente econômico age sozinho. Por isso, administradores de companhias são muitas vezes obrigados a se conformar em não obter o melhor resultado possível.

Demonstra-se, assim, mais uma condicionante do bom resultado de uma decisão negocial, não podendo os administradores serem considerados culpados por não serem capazes de alcançar o melhor resultado imaginável em um caso particular.

Enfim, diante de todo o exposto no presente Capítulo, pôde-se analisar a principal atividade dos administradores de companhias: a tomada de decisões. Algumas das dificuldades pelas quais passam esses profissionais também foram expostas, evidenciando-se que a obtenção de lucro em um determinado negócio não está sob o seu absoluto controle.

Essa noção é de extrema importância para o presente trabalho porque, juntamente com a compreensão de como se estrutura a administração de uma companhia, nos termos da Lei das S.A. (conforme exposto no Capítulo 1), a percepção de como se dá a tomada de decisão é de grande auxílio para o estudo da business judgment rule, realizado mais adiante, no Capítulo 4 desta monografia.

Assim, será possível concluir com maior precisão se essa regra é realmente adequada ao que se presta: isentar administradores por decisões ruins cometidas de forma honesta e diligente.

Antes de partir para o estudo da regra norte-americana, contudo, faz-se necessário estudar o regime de responsabilização dos administradores de sociedades anônimas no direito brasileiro. Com isso, permite-se verificar se tal regime é compatível com o que foi visto neste Capítulo e com a própria business judgment rule, tendo-se sempre em mente que as normas jurídicas devem refletir 
a consciência de que o resultado das decisões tomadas à frente de uma sociedade empresária, em enorme parte dos casos, não está sob pleno controle dos administradores.

\author{
Eles não podem temer o risco e a competição por motivos meramente
} jurídicos ${ }^{132 / 133}$.

${ }^{132}$ Explique-se: o único corretor de uma decisão empresarial/negocial deve ser o mercado, como já colocado pelo Colegiado da CVM: "É o mercado quem deve corrigir erros reiterados de julgamento da administração, quando tomados de boa-fé, e no que era percebido pela administração da companhia como o melhor para esta. Cabe aos participantes do mercado e aos acionistas removerem administradores, reduzirem sua remuneração, e mesmo castigarem o preço das ações de uma companhia por decisões, tomadas de boa-fé e no interesse da companhia, mas que se apresentaram errôneas ex-post". Processo Administrativo Sancionador CVM n ${ }^{\circ}$ RJ2008/9574, Rel. Ana Dolores Moura Carneiro de Novaes, j. em 27 nov. 2012.

${ }^{133}$ Vale conferir, sobre esse ponto, o que escreve EISENBERG: It is often in the interests of shareholders that directors or officers choose the riskier of two alternative decisions, because the expected value of a more risky decision may be greater than the expected value of the less risky decision. For example, suppose that Corporation $\mathrm{C}$ has $\$ 100$ million in assets. C's board must choose between Decision $\mathrm{X}$ and Decision Y. Each decision requires an investment of \$I million. Decision X has a 75\% likelihood of succeeding. If the decision succeeds, $\mathrm{C}$ will gain $\$ 2$ million. If it fails, $\mathrm{C}$ will lose its $\$ 1$ million investment. Decision Y has a $90 \%$ chance of succeeding. If the decision succeeds, $\mathrm{C}$ will gain $\$ 1$ million. If it fails, $\mathrm{C}$ will recover its investment. It is in the interest of C's shareholders that the board make Decision $X$, even though it is riskier, because the expected value of Decision $X$ is $\$ 1.25$ million $(75 \%$ of $\$ 2$ million, minus $25 \%$ of $\$ 1$ million) while the expected value of Decision Y is only $\$ 900,000$ (90\% of $\$ 1$ million). If, however, the board was concerned about liability for breaching the duty of care, it might choose Decision Y, because as a practical matter it is almost impossible for a plaintiff to win a duty-ofcare action on the theory that a board should have taken greater risks than it did. A standard of review that imposed liability on a director or officer for unreasonable as opposed to irrational decisions might therefore have the perverse incentive effect of discouraging bold but desirable decisions. Putting this more generally, under an ordinary standard of care directors might tend to be unduly risk-averse, because if a highly risky decision had a positive outcome the corporation but not the directors would gain, while if it had a negative outcome the directors might be required to make up the corporate loss" EISENBERG, Melvin Aron. The Divergence of Standards of Conduct and Standards of Review in Corporate Law. Fordham Law Review. vol. 62, 1993, p. 445. 


\section{CAPÍTULO 3 - O REGIME DE RESPONSABILIDADE DOS ADMINISTRADORES DE SOCIEDADES ANÔNIMAS NO DIREITO BRASILEIRO}

Como visto, o administrador, visando ao desenvolvimento da sociedade que administra e, consequentemente, da comunidade social na qual se insere, deve sempre buscar maximizar os lucros de sua companhia, o que o leva a tomar riscos. Em outras palavras, espera-se que o administrador seja ousado na gestão dos negócios sociais, e não que atue procurando apenas não ser responsabilizado.

É o que adverte CORRÊA LIMA ao afirmar que "o administrador de uma companhia, ao exercer um poder discricionário, não procede como jurista, socorrendo-se de ensinamentos da ciência do Direito", mas "como um técnico, socorrendo-se dos ensinamentos da ciência da Administração de Empresas"134.

Deve-se ter em mente, então, que o mercado e o universo econômico não estão sob controle dos administradores, que estão sujeitos a cenários e acontecimentos adversos e imprevisíveis. Sobre esse aspecto, LAMY FILHO assevera que, "investido, para o bom exercício da função, para lograr os fins societários, obrigado a decidir questões às vezes de grande relevância em questão de minutos, o administrador é levado a cometer erros"135. Dessa forma, para o jurista, "o que distingue o mau do bom administrador é o fato de acertar mais do que erra" $" 136$.

Sendo assim, ao estabelecer o regime de responsabilização dos administradores, o legislador deve estar atento às peculiaridades da atividade de tais profissionais. De acordo com GOMES, “impõe-se (...) a necessária

\footnotetext{
${ }^{134}$ CORRÊA LIMA, Osmar Brina. Responsabilidade Civil dos Administradores de Sociedade Anônima. Rio de Janeiro: Aide, 1989. p. 135.

${ }^{135}$ LAMY FILHO, Alfredo. Temas de S.A. Rio de Janeiro: Renovar, 2007. p. 410.

${ }^{136}$ Ibid., p. 410.
} 
moderação a fim de que não desencoraje a lei, por excessivo rigor, o exercício da função de administrador de sociedade anônima"137.

\section{Como bem observa ADAMEK,}

Coloca-se, assim, a delicada questão de equacionar a responsabilidade civil dos administradores, que, se de um lado não pode ser tratada com excessiva liberalidade, de outro lado também não deve incidir no vício oposto - pois os excessos do legislador outro efeito não teriam senão limitar a atuação de pessoas conscienciosas, capacitadas e bem-intencionadas, afastando-as da direção das empresas, para em seu lugar atrair os aventureiros, trazendo como consequências a ineficiência e a irresponsabilidade na condução dos negócios ${ }^{138}$.

Além disso, é importante ressaltar que, no exercício de suas atividades e devido à acentuada importância das sociedades anônimas para a economia nacional, os administradores possuem participação extremamente relevante no desenvolvimento das sociedades civis ${ }^{139}$.

Assim, o legislador deve considerar o fato de que eles gerem uma significativa parcela da propriedade alheia (da companhia, diretamente, e dos acionistas, indiretamente). Nesse sentido, GOMES aponta que,

Consumada a cisão entre propriedade e gestão, os administradores das sociedades anônimas, não só ocupam posição-chave na vida econômica das comunidades, como vieram a acumular poderes imensos por lidarem com interesses de numerosas pessoas $^{140}$.

Tais poderes ganham ainda mais destaque na medida em que se observa uma crescente dispersão acionária e a falta de participação dos acionistas na vida das sociedades anônimas, no que se convém chamar de fenômeno do absenteísmo. Nessa linha, CAMPOS anota que

\footnotetext{
${ }^{137}$ GOMES, Orlando. Responsabilidade dos Administradores de Sociedades por Ações. Revista de Direito Mercantil. São Paulo: nº 8, ano XI, 1972, p. 16.

138 ADAMEK, Marcelo Vieira von. Responsabilidade Civil dos Administradores de S/A e as ações correlatas. São Paulo: Saraiva, 2009. p. 193.

${ }^{139}$ Apesar de, segundo as estatísticas do Departamento Nacional de Registro do Comércio, as sociedades anônimas representarem apenas $0,22 \%$ de todas as sociedades registradas nas Juntas Comerciais do Brasil nos anos compreendidos entre 1985 e 2005, elas apresentam posição de destaque com relação à receita que geram. Disponível em <http://www.dnrc.gov.br/Estatisticas/caep0101.htm>. Acesso em 9 ago. 2013.

${ }^{140}$ GOMES, Orlando. Responsabilidade dos Administradores de Sociedades por Ações. Revista de Direito Mercantil. São Paulo: nº 8, ano XI, 1972, p. 11.
} 
Os administradores, principalmente aqueles das companhias com capital pulverizado, detêm grande parte do poder empresarial, e muitas vezes o verdadeiro poder, de fato, é exercido na administração da companhia e não na Assembléia Geral, tanto mais por conta do absenteísmo dos acionistas ${ }^{141}$.

Desse modo, devido a essas e outras peculiaridades da atividade de administração de companhias, a aplicação do regime geral de responsabilidade civil previsto no Código Civil de 2002 não se mostra adequada. Torna-se imprescindível, então, a elaboração de um regime próprio, em que, de acordo com CORRÊA LIMA, “(...) o papel do legislador [se limita] a armar uma estrutura adequada, que viabilize a otimização da capacidade gerencial"142.

É esse o entendimento prevalecente no direito norte-americano, bem explicitado pela Suprema Corte de Pensilvânia:

If the test of negligence which is applicable in the field of torts or in the estate field were similarly applicable in the business or banking field, it would realistically be very difficult if not almost impossible to secure the services of able and experienced corporate directors. Such persons would rarely ever accept a directorship if they could be held liable for every "bad" account or every mistake of judgment ${ }^{143 / 144}$.

Sendo assim, vale trazer a conclusão de CINTRA a respeito das peculiaridades do regime de responsabilidade dos administradores:

O sistema de responsabilidade dos administradores de fato merece cuidados próprios e não pode ser tomado dentro dos aspectos gerais previstos na legislação civil. A política legislativa e judiciária a respeito da responsabilidade ditará os contornos do grau de risco a ser assumido em cada negócio, o que terá impactos diretos na economia e crescimento do país. É preciso lembrar que o Judiciário não detém os conhecimentos

\footnotetext{
${ }^{141}$ CAMPOS, Luiz Antonio de Sampaio. Deveres e Responsabilidades. In: LAMY FILHO, Alfredo; PEDREIRA, José Luiz Bulhões (Org.). Direito das Companhias. Rio de Janeiro: Forense, 2009. p. 1.085. No mesmo sentido, de acordo com REQUIÃO, “[a] enorme dispersão do capital em ações, que a economia moderna apresenta, pelas mãos de inumeráveis acionistas, os afasta da empresa, criando o absenteísmo na participação e colaboração dos negócios sociais. Esse problema, já registrado pelos juristas e economistas, resulta dos objetivos e das intensões peculiares a cada investidor, e constitui uma consequiência da liberdade do mercado de capitais, no jogo das Bolsas de Valores" REQUIÃO, Rubens. O Controle e a Proteção dos Acionistas. In: WALD, Arnoldo (Coord.). Doutrinas Essenciais de Direito Empresarial. Rio de Janeiro: Revista dos Tribunais, 2009. vol. 3. p. 1001.

${ }^{142}$ CORRÊA LIMA, Osmar Brina. Responsabilidade Civil dos Administradores de Sociedade Anônima. Rio de Janeiro: Aide Ed., 1989. p. 46.

143 Smith v. Brown. Borhek Co., 414, Pa. 325, 200 A. 2d. 398 (1964).

${ }^{144} \mathrm{E}$ é justamente o que ocorre também no direito brasileiro, como aponta LUCENA: "Se o direito societário elaborou, como hoje reconhece a doutrina majoritária, a sua própria teoria das nulidades, assim independente da teoria comum de direito civil, cumpre igualmente admitir que o direito societário vem também introduzindo, na teoria da responsabilidade civil dos administradores de sociedades, critérios próprios, que a distanciam dos princípios que regem a responsabilidade civil comum" LUCENA, José Waldecy. Das sociedades anônimas: comentários à lei (arts. 121 a 188). vol. 2. Rio de Janeiro: Renovar, 2009. p. 550.
} 
afetos à técnica empresarial. Por isso, conferir ao magistrado amplos poderes para, em segunda mão, avaliar a adequação da conduta do gestor para a situação concreta, poderá levar a um desaquecimento da economia. Ademais, devemos ter em mente que os acionistas, assim como os demais stakeholders, assumiram o risco quanto ao negócio bem como pelas ações do administrador.

Tais considerações, todavia, não poderão servir de escusa para abusos de poder, ações desidiosas ou contrárias aos interesses sociais. A política judicial e legislativa deve envidar seus esforços na elaboração de parâmetros objetivos de conduta, cujas regras sejam conhecidas previamente por todos aqueles envolvidos nos riscos atinentes à atividade empresarial. Isso preserva o Judiciário de ingressar de forma pretensiosa em terreno que não é de seu domínio e tomar o risco de causar consequências desastrosas a esfera macroeconômica. Ao mesmo tempo, impor-se-á deveres de diligência adequados a se assegurar o bom desempenho das funções do gestor e garantir o maior de todos os fins sociais, qual seja, o lucro ${ }^{145}$.

Enfim, vistos os princípios que o regime de responsabilidade dos administradores de sociedades anônimas deve adotar, analisar-se-á o tema à luz da Lei das S.A.

Em primeiro lugar, analisar-se-á as hipóteses de irresponsabilidade dos administradores previstas ao longo dessa lei. Destacadas essas hipóteses, a verificação de compatibilidade entre elas e a business judgment rule será mais simples, fazendo com que a sua recepção no direito brasileiro seja melhor compreendida.

Em seguida, serão estudadas as hipóteses de responsabilização dos administradores de companhias. Uma vez que o objeto de estudo deste trabalho é a responsabilização desses profissionais por atos próprios (e não por atos de outros administradores ou terceiros), dar-se-á enfoque especial ao caput do artigo 158 da Lei das S.A. frente aos seus parágrafos.

Por fim, as consequências para as companhias decorrentes do ato ilícito do administrador serão examinadas em um terceiro momento. Serão vistas, nessa oportunidade, as situações nas quais a sociedade será solidariamente responsável com o administrador perante terceiros.

${ }^{145}$ CINTRA, Antonio Carlos Fontes. Responsabilidade dos administradores perante a má fortuna do negócio e a business judgment rule. Revista de Direito Bancário e do Mercado de Capitais. v. 58, out. 2012. p. 51. 


\subsection{Da irresponsabilidade dos administradores por atos próprios}

São quatro as hipóteses de irresponsabilidade dos administradores de sociedades anônimas por atos próprios abarcadas pelo direito societário brasileiro: (i) prática de ato regular de gestão em nome da sociedade; (ii) aprovação das contas e demonstrações financeiras pela assembleia geral ordinária; (iii) cumprimento de deliberações legais de órgãos hierarquicamente superiores; e (iv) exclusão de responsabilidade pelo juiz.

\subsubsection{Prática de ato regular de gestão em nome da sociedade}

Versa a primeira parte do caput do artigo 158 da Lei das S.A. que "o administrador não é pessoalmente responsável pelas obrigações que contrair em nome da sociedade e em virtude de ato regular de gestão".

Essa regra, introduzida no direito brasileiro com a edição do Decreto-Lei $\mathrm{n}^{\mathrm{o}} 2.627 / 40^{146}$, reconhece que o administrador, atuando como órgão e em nome da sociedade, não responde pelas obrigações contraídas. A responsabilidade, portanto, será da própria companhia.

\section{Ensina TAVARES GUERREIRO que,}

No relacionamento com terceiros, é a própria sociedade anônima que se obriga, inexistindo, em consequência, qualquer razão capaz de justificar o comprometimento pessoal do administrador e de seu patrimônio particular em virtude de atos praticados como representante da companhia, ressalvadas as exceções previstas em lei, quer no diploma que rege as sociedades por ações, quer na legislação especial $(. . .)^{147}$.

Não é o suficiente, contudo, que o ato do administrador seja praticado em nome da sociedade para isentá-lo de qualquer responsabilidade. É necessário, ainda, que ele seja considerado um ato regular de gestão.

\footnotetext{
${ }^{146}$ Muito similar à primeira parte do caput do artigo 158 da Lei das S.A. vigente, assim versava o caput do artigo 121 do Decreto-Lei 2.627/40: “Art. 121. Os diretores não são pessoalmente responsáveis pelas obrigações que contraírem em nome da sociedade e em virtude de ato regular de gestão".

147 TAVARES GUERREIRO, José Alexandre. Responsabilidade dos Administradores de Sociedades Anônimas. Revista de Direito Mercantil, Industrial, Econômico e Financeiro. vol. 42. abr./jun. 1981. p. 73.
} 
Por isso, torna-se indispensável a compreensão do que significa a expressão ato regular de gestão. A Lei das S.A. não a define expressamente em momento algum.

Conforme TAVARES GUERREIRO, "tal expressão (...) não deve nem pode ser entendida com abstração do conceito de administração ordinária (...) ${ }^{" 148}$. No entendimento do autor, o legislador teria incidido em manifesta tautologia ao estabelecer como condição para a irresponsabilidade do administrador a prática de ato regular de gestão ${ }^{149}$.

Isso porque, ao passo em que a primeira parte do caput do artigo 158 estabelece que o administrador não será responsável por atos regulares de gestão praticados em nome da sociedade, a segunda parte do mesmo dispositivo prevê a regra geral de sua responsabilização.

Assim versa a norma:

Art. 158. O administrador não é pessoalmente responsável pelas obrigações que contrair em nome da sociedade e em virtude de ato regular de gestão; responde, porém, civilmente, pelos prejuízos que causar, quando proceder:

I - dentro de suas atribuições ou poderes, com culpa ou dolo;

II - com violação da lei ou do estatuto.

Desse modo, se o administrador não é responsável pelas obrigações contraídas em virtude de ato regular de gestão, mas o é por prejuízos que causar quando proceder seja dentro de suas atribuições e poderes, com culpa ou dolo, seja com violação da lei ou do estatuto, tem-se que a segunda parte do caput do artigo 158 da Lei das S.A. define o ato irregular de gestão ${ }^{150}$.

Nessa linha entende ADAMEK:

A noção antagônica da expressão "ato regular de gestão" deve compreender-se logicamente na expressão antitética "ato irregular de gestão", como verso e reverso da mesma moeda. E, como necessariamente os únicos parâmetros válidos para a aferição

\footnotetext{
148 Ibid., p. 73.

149 Ibid., p. 73.

${ }^{150}$ Conforme TAVARES GUERREIRO, “(...) os únicos parâmetros admissíveis para a aferição da regularidade do ato de gestão são exatamente os preceitos da lei e as disposições do estatuto. Assim sendo, não há sentido para a duplicidade de condições, confundindo-se o ato irregular de gestão com o ato praticado com violação da lei ou do estatuto". Ibid., p. 73.
} 
da regularidade do ato do administrador devem ser encontrados na lei ou no estatuto (ato-norma), segue-se que irregular será o ato de gestão praticado com violação da lei ou do estatuto; também o será o ato praticado fora dos limites das atribuições de seu cargo, já que semelhante atuação, por evidente, contrastará igualmente com a lei e com o estatuto ${ }^{151}$.

Então, a contrario sensu, conforme EIZIRIK, será regular o ato de gestão “(...) praticado nos limites das atribuições dos administradores e sem violação da lei ou do estatuto social"152.

Conclui-se, com isso, que não poderá ser responsabilizado o administrador que tiver agido diligentemente (de acordo com o artigo 153 da Lei das S.A.), dentro de suas atribuições e poderes (de acordo com o artigo 154 da Lei das S.A.), de boa-fé e com lealdade à companhia (de acordo com o artigo 155 da Lei das S.A.), no interesse da companhia (de acordo com os artigos 154, 155 e 156 da Lei das S.A.) e sem desrespeitar os demais dispositivos do ordenamento jurídico ${ }^{153}$.

E o motivo disso, como lembra LUCENA, é o fato de a atuação do administrador caracterizar-se como uma obrigação de meio, e não de resultado ${ }^{154}$ :

A atuação do administrator (...) erige-se em uma obrigação de meio e não de resultado, não estando sua responsabilidade vinculada ao êxito da companhia, traduzido na obtenção de lucro. Daí a conclusão de que, se de ato regular de gestão resultam prejuízos para a companhia e/ou para seus acionistas, arcam eles - sociedade e acionistas - com os danos ocorrentes. Se estes atingem a terceiros, pela respectiva indenização responderá a sociedade. Em qualquer um desses casos, jamais se poderá responsabilizar civilmente o administrador ${ }^{155}$.

\footnotetext{
${ }^{151}$ ADAMEK, Marcelo Vieira von. Responsabilidade Civil dos Administradores de S/A e as ações correlatas. São Paulo: Saraiva, 2009. p. 212.

${ }^{152}$ EIZIRIK, Nelson. A Lei das S/A Comentada. vol. II. São Paulo: Quartier Latin, 2011. p. 400.

153 TAVARES GUERREIRO, José Alexandre. Responsabilidade dos Administradores de Sociedades Anônimas. Revista de Direito Mercantil, n. 42, abr./jun. 1981, p. 74.

${ }^{154}$ Como também já estudado no item 1.4 desta monografia.

155 LUCENA, José Waldecy. Das sociedades anônimas: comentários à lei (arts. 121 a 188). vol. 2. Rio de Janeiro: Renovar, 2009. p. 561.
} 


\subsubsection{Aprovação das contas e demonstrações financeiras pela assembleia geral ordinária}

Apesar de serem titulares do direito de fiscalizar, os acionistas não têm plena liberdade para decidir o meio pelo qual o farão, cabendo a eles, assim, optar por um dos artifícios previstos pela Lei das S.A. ${ }^{156}$. EIZIRIK explica a razão disso:

É inadmissível nas sociedades anônimas - modelo jurídico concebido para um grande número de sócios - o direito à fiscalização da gestão dos negócios sociais por seus acionistas de maneira irrestrita. A atribuição de poderes ilimitados aos acionistas para fiscalizar a gestão dos negócios sociais poderia resultar, em situações extremas, na paralisia dos administradores, impedindo a companhia de atingir suas finalidades e de cumprir seu objeto social ${ }^{157}$.

Nessa linha, a Lei das S.A., no artigo 122, III, estabelece que é competência privativa da assembleia geral tomar, anualmente, as contas dos administradores e deliberar sobre as demonstrações financeiras por eles apresentadas. Tal norma constitui uma das formas de fiscalização que podem ser exercidas pelos acionistas com a permissão da lei.

Conforme TEPEDINO, as contas dos administradores são “(...) tomadas através do exame conjunto do relatório da administração e das demonstrações financeiras", que são "complementados pelo parecer do Conselho Fiscal, se em exercício, e pelo parecer do auditor independente, se houver" ${ }^{" 158 / 159}$.

\footnotetext{
${ }^{156}$ EIZIRIK, Nelson. A Lei das S/A Comentada. vol. II. São Paulo: Quartier Latin, 2011. p. 131.

${ }^{157}$ Ibid. p. 132.

158 TEPEDINO, Ricardo. Assembleia Geral. In: LAMY FILHO, Alfredo; PEDREIRA, José Luiz Bulhões (Org.). Direito das Companhias. Rio de Janeiro: Forense, 2009. p. 1.004.

${ }^{159}$ De acordo com ADAMEK, "a LSA não explicita o alcance das 'contas' dos administradores, que aparece em vários dispositivos (LSA, arts. $115, \S 1^{\circ} ; 117$, § $1^{\circ}, g$; 122, III; 132, I; 134, § $3^{\circ}$; 142, V; e 148, par. ún.). 'Contas', é claro, não é sinônimo de 'demonstrações financeiras' (pois, do contrário, o legislador teria sido redundante). $\mathrm{O}$ termo deve ser entendido como o resultado da gestão administrativa, em parte referida no relatório dos administradores (LSA, art. 133, I); as contas são, pois, a demonstração genérica do estado ou da situação das operações realizadas na administração da companhia, dedutíveis da interpretação conjugada dos resultados das demonstrações financeiras e dos esclarecimentos postos à consideração dos acionistas por meio dos relatórios dos órgãos da administração, conjugados com os pareceres de órgãos de fiscalização e de auditores, e eventualmente complementados por esclarecimentos adicionais prestados em assembléia" ADAMEK, Marcelo Vieira von. Responsabilidade Civil dos Administradores de S/A e as ações correlatas. São Paulo: Saraiva, 2009. p. 259.
} 
O relatório, cuja principal função é prestar as contas da administração da companhia, deve expor de forma clara, dentre outros, todos os acontecimentos que influíram na consecução do objeto social, os lucros e prejuízos e os investimentos realizados pela sociedade. Nesse sentido, VALVERDE afirma que tal relatório deve exprimir,

(...) com clareza, todos os acontecimentos que influíram na exploração do objeto social, as causas determinantes dos prejuízos, as modificações ou alterações havidas na legislação, que interessar à sociedade, notadamente no que respeita a impostos e taxas. Explicará, quanto possível, sem revelar segredos de indústria ou comércio, as verbas constantes do balanço, as importâncias levadas aos diferentes fundos de amortização e de reserva e finalizará com a proposta de distribuição do dividendo, na forma prescrita nos estatutos. Se a sociedade estiver filiada a outras ou sobre outras exercer o controle, a diretoria deverá também, no seu relatório, dar precisas informações sobre a situação dessas sociedades ${ }^{160}$.

Já as demonstrações financeiras, em consonância com o artigo 176 da Lei das S.A., devem expor a situação do patrimônio da companhia e as mutações ocorridas no exercício correspondente. Referida norma exige que a diretoria elabore, para tanto, as seguintes demonstrações: (i) balanço patrimonial; (ii) demonstração dos lucros ou prejuízos acumulados; (iii) demonstração do resultado do exercício; (iv) demonstração dos fluxos de caixa; e, se companhia aberta, (v) demonstração do valor adicionado.

Vale ressaltar, como apontado por PEDREIRA e ROSMAM, que, mesmo não tendo esta finalidade, as demonstrações financeiras podem servir de ferramenta para a prestação de contas, “(...) porque os efeitos patrimoniais dos atos praticados pelos administradores são registrados na escrituração mercantil, a partir da qual são elaboradas as demonstrações"161.

O parecer do conselho fiscal, por sua vez, tem como função informar aos acionistas "sobre a regularidade dos documentos técnicos da prestação de contas,

160 VALVERDE, Trajano de Miranda. Sociedade por Ações. $2^{\mathrm{a}}$ ed. v. 2. Rio de Janeiro: Forense, 1953. p. 130.

${ }^{161}$ PEDREIRA, José Bulhões; ROSMAN, Luiz Alberto Colonna. Aprovação das Demonstrações Financeiras, Tomada de Contas dos Administradores e seus Efeitos. Necessidade de Prévia Anulação da Deliberação que Aprovou as Contas dos Administradores para Propositura de Ação de Responsabilidade. In: CASTRO, Rodrigo R. Monteiro de; ARAGÃO, Leandro Santos de (Org.). Sociedade Anônima: 30 anos da Lei 6.404/76. São Paulo: Quartier Latin, 2007. p. 43. 
recomendando ou não a sua aprovação" ${ }^{162}$. Frise-se, aqui, que essa recomendação não tem efeito vinculativo aos acionistas, uma vez que a aprovação das contas é de competência privativa da assembleia geral ${ }^{163}$.

Finalmente o parecer do auditor independente explicita a análise das demonstrações financeiras dessas sociedades, por força do artigo $177, \S 3^{\circ}$, da Lei das S.A. Dessa forma, tal parecer confere credibilidade e veracidade às demonstrações das companhias, uma vez que os auditores têm a função de zelar por sua fidedignidade e confiabilidade ${ }^{164}$.

Visto isso, cumpre ressaltar, ainda, que a votação das contas e das demonstrações financeiras nem sempre serão no mesmo sentido. É possível que uma seja rejeitada, ao passo que a outra seja aprovada ${ }^{165}$. A esse respeito, vale destacar o exposto por VALVERDE:

Tecnicamente, a assembleia geral ordinária deverá tomar duas deliberações: uma, sobre o balanço; outra, sobre as contas da diretoria, tendo em vista o parecer do Conselho Fiscal. Realmente. O balanço pode refletir a situação real da sociedade e ter sido apresentado, pela diretoria, com estrita observância das prescrições legais. Mas a gestão dos negócios sociais pode ter sido desastrosa, em consequência de atos ou operações praticados pelos diretores, com manifesta violação à lei ou os estatutos e até agido maliciosamente na administração da sociedade. Verificada a exatidão do balanço, a assembleia não deixará de aprová-lo, sem que, entretanto, essa aprovação envolva a aprovação dos resultados, que ele positiva. (...) A aprovação do balanço não significa, pois, a exoneração da responsabilidade dos diretores e fiscais ${ }^{166}$.

\footnotetext{
${ }^{162}$ EIZIRIK, Nelson. A Lei das S/A Comentada. vol. II. São Paulo: Quartier Latin, 2011. p. 151. De acordo com o autor, no entanto, "não cabe ao conselho fiscal verificar se os administradores administram bem, mas se o fazem de modo correto, conforme a Lei das S.A. e o estatuto. O mérito, a conveniência e a oportunidade dos atos praticados pelo conselho de administração e pelos diretores não podem ser reavaliados pelo conselho fiscal, incumbindo-lhe apenas dizer se foram praticados de acordo com a Lei das S.A. e o estatuto" Ibid. p. 151.

${ }^{163}$ Ibid. p. 151.

164 Ibid., p. 150.

165 A título de exemplo, TEPEDINO destaca que "as contas podem ser rejeitadas porque a Assembléia entendeu que os administradores, por conduta ilícita, lesaram a companhia. Todavia, se as demonstrações retratarem fielmente a situação financeira, refletindo, inclusive, a ação danosa da administração sobre ela (o que deve ocorrer indeclinavelmente), devem aprová-las, sem que isso de nenhum modo implique exoneração pelos prejuízos causados. Por outro lado, a Assembléia pode julgar correta a atuação dos administradores, aprovando-lhes as contas, mas discordar deste ou daquele lançamento no balanço ou em outra demonstração financeira, emendando-o" TEPEDINO, Ricardo. Assembleia Geral. In: LAMY FILHO, Alfredo; PEDREIRA, José Luiz Bulhões (Org.). Direito das Companhias. Rio de Janeiro: Forense, 2009. p. 1.005.

166 VALVERDE, Trajano de Miranda. Sociedade por Ações. $2^{\mathrm{a}}$ ed. v. 2. Rio de Janeiro: Forense, 1953. p. 138.
} 
Caso as contas e demonstrações financeiras forem aprovadas sem reservas, dispõe o artigo $134, \S 3^{\circ}$, da Lei das S.A. que ficam os administradores e fiscais da companhia exonerados de responsabilidade, salvo erro, dolo, fraude ou simulação.

Esta é a redação da norma:

Art. 134. (...)

$\S 3^{\circ} \mathrm{A}$ aprovação, sem reserva, das demonstrações financeiras e das contas, exonera de responsabilidade os administradores e fiscais, salvo erro, dolo, fraude ou simulação (artigo 286).

Segundo PEDREIRA e ROSMAN, o efeito de referida aprovação se dá, de forma irrevogável e irretratável, na quitação dos administradores pelo cumprimento de seus deveres legais. Assim entendem os mencionados autores:

A deliberação que aprova as contas dos administradores, expressa ou implicitamente (pela aprovação das demonstrações financeiras sem reservas), é ato jurídico que tem efeito na esfera jurídica dos administradores, pois os exonera de responsabilidade. É, como já referido, uma quitação pelo cumprimento dos seus deveres legais. Os atos dessa natureza - mesmo sem se tratar de um ato unilateral, como é a deliberação da assembléia geral de companhia - são irrevogáveis ou irretratáveis ${ }^{167}$.

Trata-se, aqui, da figura do quitus, que se justifica na medida em que confere segurança jurídica aos administradores de sociedades anônimas, não os sujeitando a inesperadas investidas ao longo do exercício de suas atividades. Segundo LAZZARESCHI NETO, o quitus, ao lado da business judgment rule, seria uma salvaguarda ao arriscado ofício dos administradores, conforme a seguir:

Ao assumirem a delicada missão de administrar os negócios sociais, os administradores colocam em risco seu nome e patrimônio em prol da companhia. Justamente por isso a Lei Societária lhes confere certas salvaguardas, sem as quais profissionais capacitados, respeitados e responsáveis jamais aceitariam exercer tal função. Daí o legislador ter criado dois "portos-seguros" em favor dos administradores: (i) a regra da decisão negocial (business judgment rule, originada no Direito norte-americano, e, de certa forma, refletida no art. $159, \S 6^{\circ}$, da Lei das S.A.), segundo a qual os gestores não são pessoalmente responsáveis por prejuízos causados por erros de avaliação cometidos de

167 PEDREIRA, José Bulhões; ROSMAN, Luiz Alberto Colonna. Aprovação das Demonstrações Financeiras, Tomada de Contas dos Administradores e seus Efeitos. Necessidade de Prévia Anulação da Deliberação que Aprovou as Contas dos Administradores para Propositura de Ação de Responsabilidade. In: CASTRO, Rodrigo R. Monteiro de; ARAGÃO, Leandro Santos de (Org.). Sociedade Anônima: 30 anos da Lei 6.404/76. São Paulo: Quartier Latin, 2007. p. 43. 
boa-fé na condução dos negócios sociais; e (ii) a exoneração de responsabilidade dos administradores mediante a aprovação, sem reserva, das contas e das demonstrações financeiras ${ }^{168}$.

Ressalte-se, por fim, que, caso haja erro, dolo, fraude ou simulação, a deliberação não surtirá os efeitos acima expostos somente se for anulada em juízo no prazo de dois anos, contados da própria deliberação.

Isso porque o mencionado dispositivo remete ao artigo 286 da mesma lei, cuja redação é a seguinte:

Art. 286. A ação para anular as deliberações tomadas em assembléia-geral ou especial, irregularmente convocada ou instalada, violadoras da lei ou do estatuto, ou eivadas de erro, dolo, fraude ou simulação, prescreve em 2 (dois) anos, contados da deliberação.

Assim, tendo a assembleia aprovado as contas da administração e as demonstrações financeiras sem reservas, fica a sociedade vinculada aos efeitos dessa deliberação, a não ser que a anule por meio de ação judicial no prazo acima mencionado.

A esse respeito, é assente na doutrina e na jurisprudência o entendimento de que a deliberação em assembleia posterior no sentido de se ajuizar ação de responsabilidade em face do administrador, nos termos do artigo 159 da Lei das S.A., não altera nem revoga implicitamente a deliberação pela aprovação, sem reservas, das contas e das demonstrações financeiras.

Foi nesse sentido que o STJ julgou o Recurso Especial no 1.313.725-SP, em que a Sadia S.A. buscava reparações por prejuízos causados por seu exdiretor financeiro em decorrência de investimentos em derivativos cambiais sem a observância da política de investimentos da companhia ${ }^{169}$. Destaca-se, quanto a isso, o seguinte trecho do voto do Ministro Relator Ricardo Villas Bôas Cueva:

Verifica-se que a regra do artigo $134, \S 3^{\circ}$, da Lei $n^{\circ} 6.404 / 76$ é especial em relação ao artigo 159 do mesmo diploma legal, de modo que, no caso de aprovação de contas, não bastaria a prévia deliberação da assembleia geral para a propositura da ação de

\footnotetext{
${ }^{168}$ LAZZARESCHI NETO, Alfredo Sérgio. Efeitos da Aprovação das Contas e das Demonstrações Financeiras das Companhias. In: KUYVEN, Luiz Fernando Martins. Temas essenciais de direito empresarial: estudos em homenagem a Modesto Carvalhosa. São Paulo: Saraiva, 2012. p. 423 e 424. $169 \mathrm{O}$ caso Sadia será analisado no item 5.4.1, à luz da business judgment rule.
} 
responsabilidade civil, mas, sim, antes ou concomitantemente, o ajuizamento de ação de anulação da assembleia que aprovou as contas.

(...)

Nessa linha de raciocínio, somente após o trânsito em julgado da sentença que acolher a anulatória, pela ocorrência dos citados vícios, é possível ajuizar a ação de responsabilidade pertinente ${ }^{170}$.

\section{Diante disso, CAMPOS ensina que}

só há um caminho para a ação social quando houver prévia aprovação de contas, que passa pela necessária desconstituição judicial dessa deliberação. A ação social deverá ser precedida ou cumulada com ação que vise à anulação da deliberação assemblear que tiver aprovado as contas.

Deve-se, porém, atentar para o fato de que os prazos prescricionais são diferentes para cada uma das ações: 3 anos para a ação social e 2 anos para a ação que pretenda anular deliberação assemblear. Dessa forma, como os prazos não são côngruos, ainda que não tenha prescrito o prazo para a ação social, pode ter prescrito o prazo para a ação de anulação de deliberação assemblear e, por isso, a ação social ficará prejudicada ${ }^{171 / 172}$.

Verifica-se, portanto, que o quitus corresponde a mais uma hipótese de irresponsabilidade dos administradores, conferindo a estes segurança jurídica no exercício de suas atividades. Embora criticada por parte da doutrina ${ }^{173}$, o legislador acertou ao conferir a quitação aos administradores que têm suas contas $\operatorname{aprovadas}^{174}$. É o que conclui LAZZARESCHI NETO:

Afinal, toda pessoa obrigada a prestar contas, e que as vê aprovadas sem ressalva, tem direito à descarga de suas obrigações. Sem essa salvaguarda da Lei das S.A., profissionais capacitados, respeitados e responsáveis dificilmente aceitariam a nobre

\footnotetext{
${ }^{170}$ STJ, REsp n. 1313725-SP, Rel. Ministro Ricardo Villas Bôas Cueva, Brasília, 29 jun. 2012. No mesmo sentido, os seguintes acórdãos: STJ, AgRg no Ag n. 640.050/RS, Rel. Ministro Luis Felipe Salomão, Brasília, 19 mai. 2009; STJ, AgRg no Ag n. 950.104/DF, Rel. Ministro Massami Uyeda, Brasília, 19 mar. 2009; e STJ, REsp n. 257.573/DF, Rel. Ministro Waldemar Zveiter, Brasília, 8 mai. 2001.

${ }^{171}$ CAMPOS, Luiz Antonio de Sampaio. Op. cit., p. 1253-1254.

172 Assim como CAMPOS, EIZIRIK também entende que "o voto favorável à aprovação das contas do exercício é incompatível com a aprovação de propositura da ação de responsabilidade contra os administradores". EIZIRIK, Nelson. Temas de direito societário. Rio de Janeiro: Renovar, 2005, p. 113. ${ }^{173}$ Para ADAMEK, por exemplo, "é evidente que assim não deveria ser e não faltam objeções sérias contra o efeito liberatório do quitus dado aos administradores". ADAMEK, Marcelo Vieira von. Responsabilidade Civil dos Administradores de S/A e as ações correlatas. São Paulo: Saraiva, 2009. p. 255.

${ }^{174}$ Essa regra, contudo, não é comum nos outros ordenamentos jurídicos. No direito italiano, o artigo 2.434 do Código Civil determina que a aprovação do balanço não exonera os administradores de responsabilidade: "L'approvazione del bilancio da parte dell'assemblea non implica liberazione degli amministratori, dei direttori generali e dei sindaci per le responsabilità incorse nella gestione sociale"; no direito alemão, a lei das sociedades por ações, em seu $\S 119$, dispõe que a aprovação dos atos dos administradores não caracteriza renúncia aos direitos de reparação de prejuízos; na Espanha, a Ley de Sociedades de Capital, em seu artigo 238, item 4, determina que "la aprobación de las cuentas anuales no impedirá el ejercicio de la acción de responsabilidad ni supondrá la renuncia a la acción acordada o ejercitada".
} 
função da administração, porquanto permaneceriam sujeitos por longo período a investidas de oportunistas, nem sempre destinadas a proteger o patrimônio social ${ }^{175}$.

\subsubsection{Cumprimento de deliberações lícitas de órgãos hierarquicamente superiores}

A estrutura de órgãos de uma sociedade anônima, como se sabe, é hierarquicamente definida. A assembleia geral é o órgão de maior hierarquia e tem poderes para decidir todos os negócios relativos ao objeto social e tomar as resoluções que julgar convenientes à sua defesa e desenvolvimento, conforme estabelece o artigo 121 da Lei das S.A.

Como se extrai do artigo 122 do mesmo diploma legal, compete privativamente à assembleia geral: (i) reformar o estatuto social; (ii) eleger ou destituir, a qualquer tempo, os administradores e fiscais da companhia, ressalvado o disposto no inciso II do artigo 142; (iii) tomar, anualmente, as contas dos administradores e deliberar sobre as demonstrações financeiras por eles apresentadas; (iv) autorizar a emissão de debêntures, ressalvado o disposto nos $\S \S 1^{\circ}, 2^{\circ}$ e $4^{\circ}$ do artigo 59 da Lei das S.A.; (v) suspender o exercício dos direitos do acionista; (vi) deliberar sobre a avaliação de bens com que o acionista concorrer para a formação do capital social; (vii) autorizar a emissão de partes beneficiárias; (viii) deliberar sobre transformação, fusão, incorporação e cisão da companhia, sua dissolução e liquidação, eleger e destituir liquidantes e julgarlhes as contas; e (ix) autorizar os administradores a confessar falência e pedir concordata $^{176}$.

O conselho de administração, imediatamente inferior à assembleia geral no que concerne à hierarquia social, tem como funções, em consonância com o artigo 142 da Lei das S.A.: (i) fixar a orientação geral dos negócios da companhia; (ii) eleger e destituir os diretores da companhia e fixar-lhes as atribuições, observado o que a respeito dispuser o estatuto; (iii) fiscalizar a gestão

\footnotetext{
175 LAZZARESCHI NETO, Alfredo Sérgio. Efeitos da Aprovação das Contas e das Demonstrações Financeiras das Companhias. In: KUYVEN, Luiz Fernando Martins. Temas essenciais de direito empresarial: estudos em homenagem a Modesto Carvalhosa. São Paulo: Saraiva, 2012. p. 435.

${ }^{176}$ Hoje substituída pela recuperação judicial, nos termos da Lei 11.101, de 9 de fevereiro de 2005.
} 
dos diretores, examinar, a qualquer tempo, os livros e papéis da companhia, solicitar informações sobre contratos celebrados ou em via de celebração, e quaisquer outros atos; (iv) convocar a assembleia-geral quando julgar conveniente, ou no caso do artigo 132; (v) manifestar-se sobre o relatório da administração e as contas da diretoria; (vi) manifestar-se previamente sobre atos ou contratos, quando o estatuto assim o exigir; (vii) deliberar, quando autorizado pelo estatuto, sobre a emissão de ações ou de bônus de subscrição; (viii) autorizar, se o estatuto não dispuser em contrário, a alienação de bens do ativo não circulante, a constituição de ônus reais e a prestação de garantias a obrigações de terceiros; e (ix) escolher e destituir os auditores independentes, se houver.

Assim, em relação à hierarquia entre os órgãos das sociedades anônimas, COMPARATO ensina que,

(...) se cada um desses órgãos básicos é dotado de poder próprio, eles não se colocam no mesmo nível, mas organizam-se hierarquicamente. No modelo legal, é, incontestavelmente, a assembleia geral o órgão primário, ou imediato, que reveste os demais, elegendo os seus membros e podendo demiti-los (LSA, art. 122, $\mathrm{n}^{\circ}$ II). Nesse sentido estritamente jurídico, nem sempre coincidente com a realidade econômica, ela é, sem dúvida, o poder supremo da companhia, como diz o Código das Obrigações suíço (art. 698), ou órgão supremo, como preferiu declara a Lei Geral mexicana de sociedades mercantis (art. 178) ${ }^{177}$.

Portanto, de acordo com PEDREIRA e LAMY FILHO, a "Assembleia Geral exerce poder hierárquico sobre o Conselho de Administração e o Conselho Fiscal, e o Conselho de Administração exerce poder sobre os diretores"178.

Diante disso, verifica-se que os administradores, não raro, se veem cumprindo deliberações tomadas por órgãos superiores. A assembleia geral emite decisões a serem obedecidas por diretores e conselheiros, ao passo que o conselho de administração vincula os diretores às suas deliberações.

177 COMPARATO, Fábio Konder. O Poder de Controle na Sociedade Anônima. 3. ed. Rio de Janeiro: Forense, 1983. p. 17.

178 PEDREIRA, José Luiz Bulhões; LAMY FILHO, Alfredo. Estrutura da Companhia. In: LAMY FILHO, Alfredo; PEDREIRA, José Luiz Bulhões (Org.). Direito das Companhias. Rio de Janeiro: Forense, 2009. p. 805. 
E, tendo a deliberação sido regularmente tomada, não há razões para se responsabilizar o administrador que a seguir. Ora, tendo a assembleia geral manifestado a vontade da companhia licitamente, caberá aos diretores, que executam os atos sociais, satisfazer tal vontade. Se, com isso, a companhia vier a sofrer prejuízos, não poderá ela exigir a reparação com o patrimônio de seus diretores.

Dessa forma, como conclui CAMPOS, "o administrador também não responde civilmente quando der cumprimento às decisões da Assembléia Geral às quais deva obedecer" ${ }^{\prime \prime}$.

Contudo, as deliberações dos órgãos coletivos nem sempre são lícitas. Com isso, o administrador, frente a uma deliberação ilícita, encontra-se em situação de difícil solução: ou desrespeita a lei, ou desrespeita a deliberação tomada por órgão superior, podendo, por isso, ser destituído de seu cargo ${ }^{180}$.

PEDREIRA e LAMY FILHO apontam a solução para esse dilema, afirmando que a lei deverá sempre prevalecer sobre deliberações ilícitas, devendo os administradores, assim, deixar de cumprir aquelas instruções que não respeitarem o ordenamento:

Na hipótese de conflito entre deliberação da assembleia e o preceito legal de não violar a lei ou estatuto, este há de prevalecer. É inquestionável que a Assembléia Geral não pode validamente dar instruções ilegais aos administradores e que estes não têm apenas a faculdade - mas o dever - de não cumprir ordens ilegais.

Entretanto, a ilicitude das deliberações da assembleia geral e do conselho de administração nem sempre é explícita. Nesses casos, os autores defendem que o administrador também deve recusar seu cumprimento:

Mas nem sempre a ilegalidade de uma ordem é manifesta, ou incontrovertida, e toda empresa de algum porte mantém serviço de assistência jurídica, de que se valem os administradores para se assegurarem da legalidade de seus atos. $\mathrm{O}$ administrador conserva, evidentemente, a liberdade de agir segundo suas conviç̧ões, e se não

\footnotetext{
${ }^{179}$ CAMPOS, Luiz Antonio de Sampaio. Op. cit., p. 1.217.

${ }^{180}$ De acordo com o artigo 122, II, da Lei das S.A., é competência privativa da assembleia geral eleger ou destituir, a qualquer tempo, os administradores da companhia. Nessa linha, o artigo 142, II, estabelece que é competência do conselho de administração eleger e destituir os diretores da companhia e fixar-lhes as atribuições.
} 
consegue convencer os serviços jurídicos ou a maioria da assembléia da ilegalidade da ordem, deve recusar-se a cumpri-la; mas o fato de assim agir não impede que a Assembléia Geral exerça o poder de destituí-lo ${ }^{181}$.

O administrador, então, será pessoalmente responsabilizado se seguir as instruções de uma deliberação ilegal advinda de um órgão hierarquicamente superior, uma vez que, invariavelmente, agiria em confronto com a lei e/ou o estatuto social $^{182 / 183}$.

Assim, por exemplo, se o conselho de administração deliberar pela cisão da companhia, tema de competência privativa da assembleia geral, deverão os diretores se abster de realizar qualquer ato visando ao que foi deliberado.

\section{Nas palavras de TAVARES GUERREIRO,}

o Diretor não está adstrito necessariamente à imposição indevida que lhe faça o Conselho de Administração, se esta contrariar os imperativos legais e estatutários que regem sua conduta. A hierarquia dos órgãos em questão não suprime os deveres aos quais se acham jungidos ex vi legis os Diretores, cabendo-lhes o ônus de resistir a determinações em contrário. Da mesma forma, como sustenta a melhor doutrina, todo e qualquer administrador tem o poder-dever de impugnar ou não acatar as deliberações assembleares da lei ou discrepantes do estatuto ${ }^{184}$.

\subsubsection{Exclusão de responsabilidade pelo juiz}

De acordo com o artigo $159, \S 6^{\circ}$, da Lei das S.A., o juiz poderá reconhecer a exclusão da responsabilidade do administrador se convencido de que este agiu de boa-fé e visando ao interesse da companhia. Dessa forma, ajuizada ação social

\footnotetext{
${ }^{181}$ PEDREIRA, José Luiz Bulhões; LAMY FILHO, Alfredo. Estrutura da Companhia. In: LAMY FILHO, Alfredo; PEDREIRA, José Luiz Bulhões (Org.). Direito das Companhias. Rio de Janeiro: Forense, 2009. p. 807.

182 Destaque-se, nesse sentido, a visão de ADAMEK: "A bem da verdade, o administrador que, de forma cega e submissa, limitar-se a dar cumprimento a toda e qualquer deliberação de outro órgão jamais estará dando regular cumprimento ao dever de diligência; ao contrário, estará positivamente violando-o (por ser passivo, e não ativo) e, com isso, expondo-se à responsabilidade civil, sem que possa invocar a falta alheia como causa excludente de sua própria responsabilidade". ADAMEK, Marcelo Vieira von. Responsabilidade Civil dos Administradores de S/A e as ações correlatas. São Paulo: Saraiva, 2009. p. 142.

183 Vale citar, aqui, a diferenciação realizada por FRANÇA quanto ao cumprimento de deliberações nulas e anuláveis: "A doutrina é unânime no sentido de que os administradores não estão adstritos a cumprir as deliberações eivadas de nulidade (v. Lobo Xavier, ob. Cit., p. 369, nota 107a, com ampla notícia bibliográfica). No tocante às deliberações anuláveis, produzindo estas seus efeitos até a desconstituição, estão os administradores, em princípio, obrigados a executá-las enquanto não forem desconstituídas". FRANÇA, Erasmo Valladão Azevedo e Novaes. Invalidade das Deliberações de Assembleia de S/A. São Paulo: Malheiros Editores, 1999. p. 64.

184 TAVARES GUERREIRO, José Alexandre. Responsabilidade dos Administradores de Sociedades Anônimas. Revista de Direito Mercantil, n. 42, abr./jun. 1981, p. 78-79.
} 
ou individual contra diretor ou conselheiro de sociedade anônima, terá o juiz a faculdade de excluir a responsabilidade destes caso tenham sido leais e agido conforme os interesses da companhia.

Alguns autores entendem ser o dispositivo em questão nova hipótese de excludente de responsabilidade, como o caso fortuito e a força maior ${ }^{185}$. No entanto, não parece ser essa a melhor conclusão.

As excludentes de responsabilidade envolvem situações nas quais os acontecimentos são imprevisíveis e estranhos à vontade do agente ${ }^{186}$. Além disso, como ensina ADAMEK, a admissão de uma excludente de responsabilidade tem como pressuposto o fato de o agente não ter agido de forma culposa $^{187}$.

Ao contrário, a regra do $\S 6^{\circ}$ do artigo 159 trata de hipótese na qual o administrador, embora de boa-fé e no interesse da companhia, tiver agido com culpa. Assim, "as razões que a justificam não são externas ao agente; residem precisamente no seu estado de espírito" ${ }^{188}$.

O mencionado autor entende, então, que a situação

é hipótese de autêntica causa de justificação, na modalidade de perdão judicial, perante a qual a lei autoriza o juiz a deixar de condenar o administrador a reparar os danos causados (...)189.

CARVALHOSA vai além. Para ele, uma vez que o artigo 127 do Código de Processo Civil versa que o "juiz só decidirá por eqüidade nos casos previstos

\footnotetext{
${ }^{185}$ BULGARELLI, Waldirio. Manual das Sociedades Anônimas. 6 ed. São Paulo: Atlas, 1991. p. 164; AZEVEDO, Antônio Ivanir de. Responsabilidade civil do administrador. Revista dos Tribunais, ano 79, vol. 653 , p. 83.

${ }^{186}$ ADAMEK, Marcelo Vieira von. Responsabilidade Civil dos Administradores de S/A e as ações correlatas. São Paulo: Saraiva, 2009. p. 286.

${ }^{187}$ Ibid. p. 286.

188 Ibid. p. 286.

${ }^{189}$ Ibid. p. 287. Grifos do autor.
} 
em lei” e que o $§ 6^{\circ}$ do artigo 159 da Lei das S.A. constitui previsão legal, "o que a norma estabelece é a faculdade do juiz de decidir por equidade" ${ }^{190}$.

Continua o referido doutrinador:

Trata-se, pois, de critério de julgamento, facultado ao juiz, diverso daquele previsto no art. 131 do Código de Processo Civil, em que o livre convencimento do juiz não lhe permite decidir fora das regras contidas no direito positivo aplicáveis à espécie ${ }^{191}$.

O que ocorre, assim, é o reconhecimento, pelo juiz, de que o administrador é, de fato, responsável pelos danos causados à sociedade. Mas, autorizado pela própria lei, o próprio juiz pode excluir essa responsabilidade desde que preenchidos determinados requisitos ${ }^{192}$.

Há, nessa lógica, uma responsabilidade preexistente que poderá ser posteriormente excluída. Se assim não fosse, a lei não falaria em exclusão de responsabilidade, pois não se pode pensar em exclusão de algo que ainda não existe.

É importante ressaltar, ainda, que a lei não exige, como pressuposto para tal exclusão, que os administradores tenham agido sem culpa stricto sensu; basta que tenham atuado de boa-fé e no interesse da companhia.

Por fim, vale mencionar que, para a quase unanimidade da doutrina (embora poucos autores tratem do assunto), o $\$ 6^{\circ}$ do artigo 159 da Lei das S.A. recepciona a business judgment rule no direito brasileiro.

\footnotetext{
${ }^{190}$ CARVALHOSA, Modesto. Comentários à Lei de Sociedades Anônimas. $4^{\mathrm{a}}$ ed. vol. 2. São Paulo: Saraiva, 2009. p. 404. No mesmo sentido, LUCENA, José Waldecy. Das sociedades por quotas de responsabilidade limitada. Rio de Janeiro: Renovar, p. 365; VERÇOSA, Haroldo Malheiros Duclerc. Curso de direito comercial. São Paulo: Malheiros, 2006. vol. 2, p. 465.

${ }^{191}$ CARVALHOSA, Modesto. Comentários à Lei de Sociedades Anônimas. $4^{\mathrm{a}}$ ed. vol. 2. São Paulo: Saraiva, 2009. p. 404.

192 ADAMEK, comentando o artigo $159, \S 6^{\circ}$, da Lei das S.A. afirma que “(...) o juiz já avançou até o ponto de considerar o administrador culpado (ou seja, já ultrapassou as etapas de verificação da ilicitude e culpabilidade do agente, estabelecendo-as no caso concreto), mas, ainda assim, decide isentar o agente do dever de indenizar. A exclusão, portanto, ocorre a posteriori: todos os elementos do suporte fático são preenchidos, dá-se a incidência da regra e surge o dever de indenizar, mas, por intervenção do juiz, o administrador é isentado do dever de repara o dano" ADAMEK, Marcelo Vieira von. Responsabilidade Civil dos Administradores de S/A e as ações correlatas. São Paulo: Saraiva, 2009. p. 287.
} 
Nesse sentido, conforme NASCIMENTO:

A regra do julgamento do negócio (business judgment rule) encontra guarda no artigo $159, \S 6^{\circ}$, da Lei $n^{\circ} 6.404 / 76$, e consiste em reconhecer que o Poder Judiciário não deve rever o mérito de decisão negocial tomada pela administração, encorajando os administradores a servir à companhia de forma equilibrada, porém, assumindo riscos inerentes ao empreendedorismo ${ }^{193}$.

No entanto, entende-se que a business judgment rule não é compatível com esse dispositivo.

Em primeiro, porque o $\S 6^{\circ}$ do artigo 159 é aplicável, como visto acima, somente depois de reconhecida a responsabilidade do administrador, ao passo que, pela business judgment rule, não há qualquer reconhecimento de responsabilidade. Em segundo, porque os elementos que servem de requisito para exclusão da responsabilidade pelo juiz (boa-fé e interesse da companhia) não contemplam todos os elementos da regra norte-americana ${ }^{194}$.

\subsection{Da responsabilidade dos administradores}

O artigo 158 da Lei da S.A. enumera as hipóteses genéricas de responsabilização dos administradores de companhias, estando as disposições específicas expostas ao longo da mencionada lei. Além disso, o dispositivo também distingue as hipóteses nas quais os administradores ou as companhias serão responsabilizados por atos cometidos por aqueles.

Em seu caput, a norma estabelece que o administrador responderá civilmente pelos prejuízos que causar quando proceder com culpa ou dolo, embora dentro de suas atribuições ou poderes, ou com violação da lei ou do estatuto.

O $\S 1^{\circ}$, por sua vez, disciplina a responsabilização do administrador que não procurar evitar ilícitos de outros administradores ou se com eles for

\footnotetext{
193 NASCIMENTO, João Pedro Barroso do. Medidas Defensivas à Tomada de Controle de Companhias. São Paulo: Quartier Latin, 2011. p. 226.

${ }^{194}$ Esse ponto será melhor e mais minuciosamente analisado no item 5.1 deste trabalho, em que se examinará a recepção da business judgment rule pelo direito brasileiro.
} 
conivente. Em sua segunda parte, esse parágrafo possibilita a exclusão da responsabilidade do conselheiro que divergir da reunião em que se deliberou por praticar um ilícito.

Já o $§ 2^{\circ}$ prevê hipótese de responsabilidade solidária dos administradores por prejuízos causados em virtude do não cumprimento de deveres impostos pela lei para assegurar o funcionamento normal da companhia.

$\mathrm{O} \S 4^{\mathrm{o}}$, por fim, estipula hipótese na qual será solidariamente responsável o administrador que, tendo conhecimento do não cumprimento desses deveres por outro administrador, deixar de comunicar o fato à assembleia geral.

\subsubsection{Atos praticados com culpa ou dolo}

De acordo com a segunda parte do caput do artigo 158, o administrador responderá pelos prejuízos que causar ao proceder, dentro de suas atribuições ou poderes, de forma culposa ou dolosa, ou com violação da lei ou do estatuto.

Esta é a redação do referido artigo:

Art. 158. O administrador não é pessoalmente responsável pelas obrigações que contrair em nome da sociedade e em virtude de ato regular de gestão; responde, porém, civilmente, pelos prejuízos que causar, quando proceder: I - dentro de suas atribuições ou poderes, com culpa ou dolo; II - com violação da lei ou do estatuto (grifo nosso).

Para a análise do inciso I, é necessário que se defina dois importantes elementos: (i) as atribuições e poderes dos administradores; e (ii) a aplicação da culpa lato sensu à atividade de administração de sociedades anônimas.

De acordo com EIZIRIK et al, "as atribuições e poderes dos administradores estão definidos na Lei Societária e nos estatutos”, que, por sua vez, "prevêem um conjunto de competências necessárias à exploração e ao desenvolvimento adequados das atividades sociais"195. Ainda segundo os

195 EIZIRIK, Nelson; GRAAL, Ariádna B.; PARENTE, Flávia; HENRIQUES, Marcus de Freitas. Mercado de Capitais: Regime Jurídico. $3^{\text {a }}$ ed. Rio de Janeiro: Renovar, 2011. p. 498. 
autores, também as noções de objeto e interesse sociais estão abarcadas na mencionada expressão ${ }^{196}$.

Tais noções encontram-se demarcadas pelo artigo 154 da Lei das S.A., segundo o qual "o administrador deve exercer as atribuições que a lei e o estatuto lhe conferem para lograr os fins e no interesse da companhia, satisfeitas as exigências do bem público e da função social da empresa”.

Assim,

(...) o ato praticado pelo administrador "dentro de suas atribuições ou poderes" é aquele em que foram observados, quanto à forma, as disposições legais e estatutárias relativas aos limites de competência e, quanto ao conteúdo, de acordo com o disposto no artigo 154 da Lei Societária, o objeto e o interesse sociais ${ }^{197}$.

No que diz respeito ao segundo elemento (a aplicação da culpa lato sensu aos administradores de sociedades anônimas), ensina ADAMEK que ela “corresponde à culpa civil (CC, art. 186). Mas, para bem caracterizá-la, é necessário recorrer ao standard específico do dever de diligência (LSA, art. $153)^{\prime 198}$.

Dessa forma, o conceito abrange atos negligentes, imprudentes, imperitos e dolosos, que devem ser examinados com base no dever de diligência do direito societário.

Segue o autor:

(...) a diligência exigida do administrador é a normal ou ordinária, e não de maior ou menor intensidade, mas que deve ser aferida em confronto com o tipo de atividade exercida pela companhia, inclusive a sua dimensão e importância, os recursos disponíveis e a sua qualidade de administrador de bens alheios ${ }^{199}$.

Ainda, faz-se necessário ressaltar que é entendimento consolidado na doutrina aquele pelo qual o ônus da prova, em casos envolvendo o inciso I do artigo 158, será sempre do autor da ação, conforme o artigo 333, I, do Código de

\footnotetext{
${ }^{196}$ Ibid., p. 498.

${ }^{197}$ Ibid., p. 499.

198 ADAMEK, Marcelo Vieira von. Responsabilidade Civil dos Administradores de S/A e as ações correlatas. São Paulo: Saraiva, 2009. p. 213.

${ }^{199}$ Ibid. p. 213-214.
} 
Processo Civil ${ }^{200 / 201}$. Desse modo, ao ajuizar ação em face do administrador, o autor deverá provar que este, embora dentro de suas atribuições ou poderes, agiu culposamente.

O inciso II do caput do artigo 158, ao seu turno, estabelece que o administrador será responsabilizado se proceder com violação à lei ou ao estatuto. Há, como se vê, uma grande diferença entre este inciso e o inciso I do dispositivo: o legislador não incluiu a expressão com culpa ou dolo.

Então, a fim de compreender qual a real intenção do legislador ao não mencionar a culpa lato sensu nos casos de violação da lei ou do estatuto, a doutrina se ramifica em três principais correntes: (i) responsabilidade objetiva do administrador; (ii) equivalência entre as hipóteses - responsabilidade subjetiva; e (iii) inversão do ônus da prova.

\subsubsection{Responsabilidade objetiva}

A responsabilidade objetiva está prevista no ordenamento brasileiro no parágrafo único do artigo 927 do Código Civil, pelo qual

haverá obrigação de reparar o dano, independentemente de culpa, nos casos especificados em lei, ou quando a atividade normalmente desenvolvida pelo autor do dano implicar, por sua natureza, risco para os direitos de outrem.

Ela se diferencia da responsabilidade subjetiva na medida em que só se exige uma relação entre o fato danoso e o seu autor, independentemente de culpa.

\section{Conforme PEREIRA:}

A doutrina objetiva, ao invés de exigir que a responsabilidade civil seja a resultante dos elementos tradicionais (culpa, dano, vínculo de causalidade entre uma e outro) assenta na equação binária cujos polos são o dano e a autoria do evento danoso, o que importa para assegurar o ressarcimento é a verificação se ocorreu o evento e se dele emanou o prejuízo. Em tal ocorrendo, o autor do fato causador do dano é o responsável. Com a teoria do risco, diz Philippe Le Tourneau, o juiz não tem de examinar o caráter lícito

\footnotetext{
${ }^{200}$ Assim versa a norma: “Art. 333. O ônus da prova incumbe: I - ao autor, quanto ao fato constitutivo do seu direito".

${ }^{201}$ Nessa linha: ADAMEK, Marcelo Vieira von. Responsabilidade Civil dos Administradores de S/A e as ações correlatas. São Paulo: Saraiva, 2009. p. 214; EIZIRIK, Nelson; GRAAL, Ariádna B.; PARENTE, Flávia; HENRIQUES, Marcus de Freitas. Mercado de Capitais: Regime Jurídico. $3^{\mathrm{a}}$ ed. Rio de Janeiro: Renovar, 2011. p. 500 e 501; BORBA, José Edwaldo Tavares. Direito Societário. $8^{a}$ ed. Rio de Janeiro: Renovar, 2003. p. 424.
} 
ou ilícito do ato imputado ao pretenso responsável: as questões de responsabilidade transformam-se em simples problemas objetivos que se reduzem à pesquisa de uma relação de causalidade ${ }^{202}$.

Dessa forma, ainda que não tenha agido de forma dolosa, negligente, imprudente e imperita, a pessoa que praticar ato ilícito e cometer um dano será responsabilizada pela reparação deste nos casos especificamente previstos em lei.

No âmbito da administração de companhias, uma pequena parte da doutrina defende que o inciso II do artigo 158 da Lei das S.A. representa previsão específica de caso de responsabilização objetiva. Para os defensores dessa tese, o mencionado inciso, ao omitir a expressão com culpa ou dolo, teria admitido a responsabilidade dos administradores decorrente somente de um ato ilícito, dano e o nexo de causalidade entre o ato e o dano - a culpa, então seria desnecessária.

Para CARVALHOSA, a responsabilização objetiva dos administradores se justifica na medida em que, ao violarem a lei ou o estatuto, eles criam um grande risco de dano à companhia, sendo responsáveis por sua reparação:

Irrelevante, na espécie, o caráter culposo ou doloso da conduta do administrador. Criase, na espécie, a relação de causalidade entre a lesão material ou jurídica sofrida pela companhia e a ação ou a omissão do administrador. Desse nexo objetivo surge o dever de indenizar, independentemente de ter o administrador agido ou não com culpa ou dolo. O administrador, ao desrespeitar a lei ou o estatuto, cria um risco de dano para a companhia, sendo, por isso, responsável, cabendo-lhe, portanto, repará-1o ${ }^{203}$.

\section{Continua:}

O cumprimento da lei, como principal obrigação social de todo indivíduo, é inexcusável, não podendo, com efeito, ser arguidos os aspectos psicológicos para o seu descumprimento. Ao infringir a lei ou o estatuto, o administrador cria o risco de dano à companhia, independentemente do proveito pessoal que lhe tenha trazido tal risco, e, consequentemente, da intenção de favorecer a si próprio, a terceiros, ou de prejudicar aquele que sofre esse risco ${ }^{204}$.

\footnotetext{
${ }^{202}$ PEREIRA, Caio Mário da Silva. Responsabilidade Civil. 10a ed. Rio de Janeiro: GZ Ed., 2012. p. 356

${ }^{203}$ CARVALHOSA, Modesto. Responsabilidade Civil dos Administradores das Companhias Abertas. Revista de Direito Mercantil, Industrial, Econômico e Financeiro. São Paulo, n. 49, jan./mar. 1983. p. $17-18$.

${ }^{204}$ Ibid. p. 18.
} 
Assim também entende AZEVEDO:

No Direito societário, instituiu-se regras que qualificam a responsabilidade como objetiva, como é o caso do disposto no art. 158, II, da Lei 6.404/76, e do art. 10 do Dec. 3.708/19. Assim, responde civilmente o administrador, por violação da lei e do estatuto (sociedade por ações), ou da lei e do contrato (sociedade por quotas), não servindo como escusa a alegação de desconhecimento quanto ao teor destes ${ }^{205 / 206}$.

Entretanto, não parece ser essa a melhor interpretação a respeito do inciso II do artigo 158 da Lei das S.A. Essa linha de raciocínio não está de acordo com a sistemática do regime de responsabilidade civil dos administradores de sociedades anônimas.

Admitir a responsabilização objetiva dos administradores nesse caso caracterizaria um excessivo rigor por parte da legislação societária, sendo um grande desincentivo ao exercício dessa atividade por pessoas honestas e capacitadas. No lugar delas, pessoas despreocupadas com o próprio patrimônio e com a tomada de riscos assumiriam os cargos da administração.

Consequentemente, a gestão das companhias seria menos eficiente.

\subsubsection{Equivalência entre as hipóteses - responsabilidade subjetiva}

Diferentemente da doutrina objetiva, o regime de responsabilização subjetiva, que é a regra no direito brasileiro e está previsto por uma conjugação dos artigos 186, 187 e 921, caput, do Código Civil, exige a presença do elemento subjetivo do agente ao praticar o ato ilícito: a culpa lato sensu.

Tendo isso em vista, para outra parte da doutrina, também minoritária, a omissão da expressão com culpa ou dolo do inciso II do artigo 158 da Lei das

\footnotetext{
205 AZEVEDO, Antônio Ivanir de. Responsabilidade Civil do Administrador. Revista dos Tribunais. v. 653, mar. 1990. p. 80.

${ }^{206}$ MARIANI, no que se refere à responsabilidade de administradores de sociedades limitadas: “(...) se o contrato proíbe o aval e/ou fiança - situação diversa daquela em que silencia -, e mesmo assim o administrador prestá-las, responde objetivamente, porquanto basta constatar a infração, jamais a culpa, ou não, pelo cometimento, mesmo com autorização dos sócios, pois também eles não podem violar o contrato, sob pena de igualmente assinarem responsabilidade (CC, art. 1.080)" MARIANI, Irineu. Responsabilidade Civil dos Sócios e dos Administradores de Sociedades Empresárias (à luz do Novo Código Civil). Disponível em

<http://www.rkladvocacia.com/arquivos/artigos/art_srt_arquivo20080731125626.pdf>. Acesso em 19 mar. 2013. p. 16.
} 
S.A. não significaria diferença alguma entre as hipóteses de responsabilização dos administradores. Isso porque, necessariamente, atuar com culpa ou dolo (inciso I) seria uma violação à lei e a violação à lei ou ao estatuto (inciso II) seria sempre culposa ou dolosa.

\section{Nas palavras de COELHO,}

As duas hipóteses elencadas pelo art. 158 da Lei das S/A, na definição da responsabilidade dos administradores, são interdefiníveis. Com efeito, a ação culposa ou dolosa é, forçosamente, ilícita, violadora da lei. Se, por exemplo, um administrador deixa de aplicar disponibilidades financeiras da sociedade, ele age com negligência ou até imperícia. A natureza culposa de sua omissão é, assim, clara e indiscutível. Contudo, este mesmo comportamento caracteriza a inobservância dos deveres de diligência e de lealdade. Consequentemente, o administrador que age culposamente viola a lei. Por outro lado, toda violação à lei ou aos estatutos é uma conduta culposa ou dolosa. O administrador que descumpre norma legal ou cláusula estatutária, se não atua conscientemente, estará sendo negligente, imprudente ou imperito. Em razão da interdefinibilidade das hipóteses de responsabilização civil dos administradores de sociedade anônima, não há - ressalte-se - que distinguir a natureza delas. (...) Assim, não comporta ser feita qualquer separação entre as duas hipóteses destacadas pelo legislador, que reclamam tratamento uniforme ${ }^{207}$.

\section{Acompanhando COELHO, ADAMEK também entende que tanto o inciso}

I quanto o inciso II do artigo 158 são hipóteses da regra geral de responsabilização subjetiva prevista pelo Código Civil:

A assimilação entre as hipóteses cogitadas nos incs. I e II do art. 158 da Lei das S/A certamente é possível. A partir do instante em que a culpa lato sensu do agente resulta da violação de dever jurídico - que, de forma mediata ou imediata, tem sempre a sua fonte na lei (CF, art. 5, II) -, torna-se indiscutível que a atuação culposa do agente constitui ato ilícito, violador da lei. De igual modo, também é viável afirmar que, em princípio, a violação da lei ou do estatuto configura comportamento culposo do agente, que agiu inspirado por dolo, ou negligência, ou mesmo imprudência. Portanto, sob tal perspectiva, o art. 158 da Lei das S/A ter-se-ia limitado a repetir, sem a mesma precisão, a regra geral de responsabilidade civil por ato ilícito $(\mathrm{CC}, \text { art. 186 })^{208}$.

No entanto, essa visão também não parece ser a mais correta.

\footnotetext{
${ }^{207}$ COELHO, Fábio Ulhoa. A natureza subjetiva da responsabilidade civil dos administradores de companhia. Revista Direito de Empresa. vol. 1. p. 26-27.

208 ADAMEK, Marcelo Vieira von. Responsabilidade Civil dos Administradores de S/A e as ações correlatas. São Paulo: Saraiva, 2009. p. 218-219.
} 
Em primeiro lugar, porque não é certo pensar que, mesmo tendo atribuído redações diferentes aos dispositivos, o legislador tenha desejado expressar a mesma ideia a respeito do regime de responsabilidade dos administradores ${ }^{209}$.

Em segundo, porque não é verdadeira a presunção de que agir com violação à lei ou ao estatuto necessariamente importa agir culposa ou dolosamente. É possível que, embora tenha agido voluntariamente, o administrador não tenha sido negligente, imprudente ou imperito e nem tenha agido de má-fé.

Como exemplo, EIZIRIK et al e CUNHA PEIXOTO apontam o caso do administrador que, ao se deparar com o texto obscuro da lei e, após consultar advogados ou estudar o que diz a doutrina especialista na matéria, resolve seguir uma das interpretações possíveis. Posteriormente, sua conduta poderá ser entendida como violadora da lei, mas ele não poderá ser por ela responsabilizado, pois faltaria o elemento culpa lato sensu exigido pelo regime da responsabilidade subjetiva $^{210}$.

\subsubsection{Inversão do ônus da prova}

A grande maioria da doutrina defende a adoção não da responsabilidade objetiva nem da puramente subjetiva no caso do inciso II do caput do artigo 158 da Lei das S.A., mas, sim, a inversão do ônus da prova.

\footnotetext{
${ }^{209}$ Para ADAMEK, além de descrever as hipóteses em que os administradores serão responsabilizados, a razão pela qual a Lei das S.A. teria feito referência a dois incisos distintos teria sido a diferenciação das hipóteses de responsabilização ou não da companhia por ato de seu administrador: "No citado artigo de lei, o legislador não teria se limitado a explicitar as hipóteses ante as quais despontaria a responsabilidade civil do administrador, mas teria sim, simultaneamente, pretendido definir as diferentes situações em que o ato praticado pelo administrador o vincularia, ou então vincularia a sociedade ou ambos, perante terceiros" Ibid., p. 221.

${ }^{210}$ EIZIRIK, Nelson; GRAAL, Ariádna B.; PARENTE, Flávia; HENRIQUES, Marcus de Freitas. Mercado de Capitais: Regime Jurídico. $3^{\mathrm{a}}$ ed. Rio de Janeiro: Renovar, 2011. p. 502. Nas palavras de CUNHA PEIXOTO: "se se trata de um texto obscuro dos estatutos ou de dispositivo de lei que sugere mais de uma interpretação, e o administrador orienta-se por uma das correntes doutrinárias ou se alicerça em parecer de jurista de renome, não pode ser responsável pelos atos praticados, pois está ele isento de qualquer culpa" CUNHA PEIXOTO, Carlos Fulgêncio da. Sociedade por Ações. vol. 4. São Paulo: Saraiva, 1973. p. 78.
} 
Significa dizer que, nos casos em que houver, por parte dos administradores, violação da lei ou do estatuto, inverter-se-ão as regras do caput do artigo 333 do CPC, que assim versa:

Art. 333. O ônus da prova incumbe: I - ao autor, quanto ao fato constitutivo do seu direito; II - ao réu, quanto à existência de fato impeditivo, modificativo ou extintivo do direito do autor.

Seria esse, portanto, o princípio adotado pelo legislador ao omitir a expressão com culpa ou dolo do inciso II do artigo 158 da Lei das S.A. Nesse sentido, antes mesmo da edição da Lei das S.A., GOMES já recomendava que,

(...) quanto ao ônus da prova embora domine a tendência para atribuí-lo à sociedade, deve-se admitir que, nas violações graves, cabe a inversão, cumprindo ao administrador provar a inexistência de dano ou que não decorreu de ato $\mathrm{seu}^{211}$.

Segundo VALVERDE, ao comentar os incisos I e II do $\S 1^{\circ}$ do $\operatorname{artigo} 121$ do Decreto-lei $n^{\circ} 2.627 / 40$, que possuíam a mesma diferenciação adotada pela lei acionária atualmente em vigor, seria essa a interpretação mais adequada dos dispositivos:

Dir-se-á que a lei presume, nesses casos [de violação da lei ou do estatuto], a culpa do diretor pelo que a ele incumbirá provar que a violação da lei ou dos estatutos resultou de casos especialíssimos, por ele não provocadas ou relativamente às quais não podia ele ter nenhuma influência, ou, ainda, que os prejuízos verificados ocorreriam em qualquer hipótese. É o princípio da inversão da prova, que a lei alemã de 1937, § 84, nº 2 , generalizou, mas que o decreto-lei só consignou no caso de prejuízos derivantes de ações ou omissões infringentes da lei ou dos estatutos ${ }^{212}$.

Conclui o autor que “(...) a distinção perderia valor se, como geralmente se admite, houvesse necessidade da prova da culpa do diretor nos casos de violação da lei ou dos estatutos" $" 13$.

${ }^{211}$ GOMES, Orlando. Responsabilidade dos Administradores de Sociedades por Ações. Revista de Direito Mercantil. São Paulo: no 8, ano XI, 1972, p. 13.

${ }^{212}$ VALVERDE, Trajano de Miranda. Sociedade por Ações. $2^{\mathrm{a}}$ ed. vol. 2. Rio de Janeiro: Forense, 1953. p. 45-46.

${ }^{213}$ Ibid., p. 46. 
Não é diferente o entendimento dos redatores do anteprojeto da Lei das S.A., LAMY FILHO e PEDREIRA, para quem "a lei de sociedades por ações inverte o ônus da prova se o ato do administrador viola a lei ou estatuto (...)" ${ }^{\text {"214. }}$

A adoção desse princípio nos casos do inciso II do artigo 158 da Lei das S.A. se justifica, segundo CAMPOS, na medida em que os administradores têm uma obrigação legal e moral de conhecer efetivamente a lei e os estatutos de suas companhias:

Embora em regra o desconhecimento da lei não possa servir para autorizar o seu descumprimento, conforme a velha noção de que "a ninguém é dado desconhecer a lei", no caso da LSA e do estatuto há uma obrigação legal e mesmo moral imposta aos administradores de conhecer efetivamente, não só à luz do dever de diligência que lhes é imposto, mas também pelo fato de serem estes os diplomas que informam diretamente a atuação dos administradores. Esse fato justifica a maior rigidez no regime probatório imposto aos administradores quando se trata de violação da lei ou do estatuto, tendo, ainda, presente o fato de serem os administradores gestores de bens alheios ${ }^{215}$.

No mesmo sentido, LAMY FILHO e PEDREIRA explicam que a inversão do ônus da prova

(...) se justifica porque os administradores são profissionais - comerciantes, empresários ou técnicos - e a estrita observância da lei e do estatuto é fundamental para a proteção de todos os interessados na companhia ou na sua atividade ${ }^{216}$.

Em resumo, portanto, ao omitir a expressão com culpa ou dolo do inciso II do artigo 158, a Lei das S.A. presume (relativamente) que a conduta do administrador tenha sido culposa quando da violação da lei ou do estatuto. Caberá a ele, assim, provar a ausência de culpa em sua conduta, e não ao autor da ação, conforme a regra geral prevista no inciso I do artigo 333 do CPC.

\footnotetext{
${ }^{214}$ LAMY FILHO, Alfredo; PEDREIRA, José Luiz Bulhões. A Lei das S.A. Rio de Janeiro: Renovar, 1996. v. 2, p. 405.

${ }^{215}$ CAMPOS, Luiz Antonio de Sampaio. Op. cit., p. 1208 e 1209. Na opinião do autor, mesmo sendo a expressão lei referente às diferentes leis que tratam da conduta dos administradores, "ao examinar a conduta, do administrador, violadora da lei, o intérprete, à luz da regra aferidora da responsabilidade, que é a do dever de diligência, deve ser mais exigente quando se tratar de violação da LSA e dos estatutos do que quando se tratar das leis ou outros normativos em geral" Ibid. p. 1.209.

${ }^{216}$ LAMY FILHO, Alfredo; PEDREIRA, José Luiz Bulhões. A Lei das S.A. Rio de Janeiro: Renovar, 1996. v. 2, p. 405.
} 


\subsubsection{Responsabilidade individual e solidária}

Para que se analise as hipóteses de responsabilidade individual e solidária estabelecidas pelo artigo 158 da Lei das S.A., deve-se ter em mente que o que importa é o modo como a decisão é tomada, e não o órgão que a tomou. Como bem observa ADAMEK, "a distinção a ser aqui feita não é propriamente entre conselho de administração e diretoria, mas entre órgãos colegiados ou não"217/218 .

Explica o autor que, nos casos em que o órgão da administração atuar colegiadamente, a culpa de seus integrantes será coletiva:

nos órgãos de administração colegiada, os seus integrantes assumem responsabilidade coletiva pelas deliberações ou decisões colegiadas. O fundamento da responsabilidade do administrador continuará a residir na culpa lato sensu, consequência da violação de seus deveres gerais (como os de diligência, lealdade e vigilância), mas em caráter presumido, tanto assim que a abstenção do administrador ou a sua falta injustificada ao conclave não o isenta de responsabilidade ${ }^{219}$.

Já nos casos de órgãos de administração individual, prevalece o princípio da incomunicabilidade da culpa. Caberá ao autor da ação, então, provar a participação culposa do administrador relativa ao ato ilícito de outro administrador para que se configure a solidariedade ${ }^{220}$.

Dessa forma, percebe-se que a Lei das S.A. segue o princípio da responsabilidade por culpa própria, pelo qual o administrador não é responsável por atos ilícitos de outros administradores (artigo $158, \S 1^{\circ}$, primeira parte). Não se pode esquecer, nessa linha, que, quando responsabilizado por uma decisão tomada por um órgão colegiado, a culpa verificada é do próprio administrador, na medida em que é parte do órgão colegiado.

\footnotetext{
217 ADAMEK, Marcelo Vieira von. Responsabilidade Civil dos Administradores de S/A e as ações correlatas. São Paulo: Saraiva, 2009. p. 242.

${ }^{218}$ Como já visto no item 1.3 deste trabalho, verifica-se que, ao passo em que a diretoria é um órgão predominantemente individual (predominantemente porque nada impede que o estatuto estabeleça que determinadas matérias sejam decididas por meio de reuniões da diretoria), os conselheiros constituem um órgão colegial em sua essência, sendo suas decisões um resultado das deliberações realizadas nas reuniões do conselho de administração.

219 ADAMEK, Marcelo Vieira von. Responsabilidade Civil dos Administradores de S/A e as ações correlatas. São Paulo: Saraiva, 2009. p. 243.

${ }^{220}$ Ibid. p. 245.
} 
Porém, a própria lei prevê certas hipóteses que parecem afastar esse princípio: será o administrador responsabilizado por atos de outros administradores se com eles for conivente, se negligenciar em descobri-los ou se, deles tendo conhecimento, deixar de agir para impedir a sua prática.

Tais hipóteses, na verdade, como ressaltado por CAMPOS, não afastam a Lei das S.A. do mencionado princípio. O que nelas se verifica é uma ação ou omissão do administrador que, em conformidade com os seus deveres de diligência e lealdade, deveria buscar impedir a prática do ato ilícito por parte de outro administrador ${ }^{221}$.

Para que se exima dessa responsabilidade, versa a segunda parte do $\S 1^{\circ}$ do artigo 158 que o administrador dissidente deve consignar sua divergência em ata de reunião do órgão de administração ou, não sendo possível, dela dê ciência imediata e por escrito ao órgão da administração, ao conselho fiscal, se em funcionamento, ou à assembleia geral.

$\mathrm{O} \quad \S 2^{\circ}$ do artigo 158 estabelece que os administradores serão solidariamente responsáveis pelos prejuízos causados em virtude do não cumprimento dos deveres impostos por lei para assegurar o funcionamento normal da companhia, ainda que, pelo estatuto, tais deveres não caibam a todos eles.

Como assevera CARVALHOSA, "os atos necessários ao funcionamento normal da sociedade correspondem às obrigações de fazer impostas pela lei aos administradores, dentro da administração ordinária", o que abrange "as competências tanto do Conselho de Administração quanto dos diretores"222.

Nesses casos, devido à relevância dos mencionados deveres, cujo descumprimento pode causar graves prejuízos à companhia, a lei exige dos

${ }^{221}$ CAMPOS, Luiz Antonio de Sampaio. Op. cit., p. 1.210.

${ }^{222}$ CARVALHOSA, Modesto. Comentários à Lei de Sociedades Anônimas. $4^{a}$ ed. v. 2. São Paulo: Saraiva, 2009. p. 367. 
administradores um padrão de diligência mais elevado, devendo cuidar para que tais deveres sejam cumpridos por outros administradores. Conforme CAMPOS,

não se pode dizer que se cuida de uma responsabilidade sem culpa, pois ao impor a solidariedade aos administradores, de fato, o legislador está imputando um padrão de diligência mais elevado e específico para os administradores da companhia, no que se refere ao dever de vigilância do cumprimento dos atos necessários ao normal funcionamento da sociedade pelos demais administradores e que seria atendido, à medida que não se constatou que houve o descumprimento, por outro administrador, de um dever imposto por lei para assegurar o funcionamento normal da companhia ${ }^{223}$.

Reconhecendo (i) a complexidade das companhias abertas; (ii) o princípio da especialização a que estão sujeitos os seus administradores; e (iii) a falta de razoabilidade do ônus que estes teriam em fiscalizar os atos de outros administradores, a lei abre uma exceção às referidas companhias ${ }^{224}$. Nelas, a responsabilidade de que trata o $\S 2^{\circ}$ do artigo 158 ficará, por força de seu $\S 3^{\circ}$, restrita aos administradores que, por disposição do estatuto, tenham atribuição específica de dar cumprimento aos deveres em questão.

Enfim, o $\$ 4^{\circ}$ do mesmo artigo prevê a última hipótese genérica de responsabilização solidária de um administrador por ilícito de outro. De acordo com o dispositivo, o administrador que, tendo conhecimento do não cumprimento dos deveres que assegurem o funcionamento normal da companhia por seu predecessor ou por aquele competente nos termos do estatuto da sociedade, deixar de comunicar o fato à assembleia geral tornar-se-á por ele solidariamente responsável.

\section{Como assevera CAMPOS,}

Nos termos da LSA, não se impõe ao administrador o dever de fazer uma devassa ou de fiscalizar os atos praticados por seu predecessor, mas apenas que, caso o administrador tenha conhecimento de irregularidades de seu predecessor, o que deverá

\footnotetext{
223 Ibid., p. 1.219.

${ }^{224}$ Ibid., p. 1.220. No mesmo sentido, EIZIRIK: "Na companhia aberta, como se presume a especialização das funções, a responsabilidade é individual, daí decorrendo que, no que tange aos deveres acima mencionados, a solidariedade somente ocorre entre os administradores que têm atribuição específica de atendê-los. Assim, por exemplo, a não divulgação em tempo hábil de fato relevante acarretará, em princípio, a responsabilidade do "diretor de relações com investidores"' EIZIRIK, Nelson. A Lei das S/A Comentada. vol. II. São Paulo: Quartier Latin, 2011. p. 407.
} 
se dar no exercício da administração regular da companhia, dê notícia desse fato à Assembléia Geral ${ }^{225}$.

Por fim, o $\S 5^{\circ}$ do artigo 158 estabelece que responderá solidariamente com o administrador quem, com o fim de obter vantagem para si ou para outrem, concorrer para a prática de ato com violação da lei ou do estatuto. Trata-se da responsabilidade do terceiro que agir em conluio com o administrador.

\subsection{Responsabilidade da companhia por ato do administrador}

Além de poder ser pessoalmente responsabilizado, o administrador também poderá, em determinadas hipóteses, causar a responsabilização da companhia por seus atos. Sobre o tema, ADAMEK defende que o escopo do caput do artigo 158 da Lei das S.A., ao distinguir as hipóteses dos incisos I e II, está ligado apenas à vinculação ou não da sociedade anônima:

deve-se entender que o legislador pretendeu estabelecer as seguintes regras: $\left(1^{\mathrm{a}}\right)$ o administrador não é pessoalmente responsável pelas obrigações que contrair em nome da sociedade, em virtude de ato regular de gestão; e $\left(2^{a}\right)$ ele é civilmente responsável pelos prejuízos que causar, quando culposamente descumprir dever legal ou estatutário, sendo que, nesta última situação: ( $2^{\mathrm{a}}$.A) os atos praticados dentro do âmbito de suas atribuições obrigam a sociedade perante terceiros (ressalvado o direito de regresso contra o administrador); e ( $2^{a}$.B), em princípio, os atos praticados fora do âmbito de suas atribuições não vinculam a sociedade perante terceiros, pois são da direta $\mathrm{e}$ exclusiva responsabilidade do administrador, solução essa consentânea com o regime de publicidade das sociedades anônimas. Diz-se em princípio, porque, sob certas circunstâncias e à luz do primado da boa-fé, tais atos do administrador, apesar de exercidos fora do âmbito de suas atribuições ou além de seus poderes, podem vincular a própria sociedade, quando: (i) forem ratificados posteriormente; (ii) a sociedade deles auferir vantagem; ou (iii) a sua preservação impuser-se por efeito de outras regras e preceitos destinados a tutelar a posição jurídica de terceiros (categoria na qual se incluiriam os atos ultra vires societatis, fora do objeto social, e os praticados com excesso de poderes pelo administrador, uns e outros agora regulados pelo art. 10.15 do $\mathrm{CC})^{226}$.

Ao agir dentro de suas atribuições ou poderes, mesmo com culpa ou dolo,

o administrador ainda age como órgão da companhia e, por isso, há, nesses casos,

${ }^{225}$ CAMPOS, Luiz Antonio de Sampaio. Op. cit., p. 1.221.

${ }^{226}$ ADAMEK, Marcelo Vieira von. Responsabilidade Civil dos Administradores de S/A e as ações correlatas. São Paulo: Saraiva, 2009. p. 221-224. Grifos do autor. 
responsabilidade solidária da companhia. Esta, ao seu turno, poderá entrar com ação regressiva contra o causador do dano ${ }^{227}$.

A mesma lógica não se aplica, contudo, aos casos em que houver violação à lei ou ao estatuto. De acordo com TAVARES GUERREIRO,

o diretor só é órgão da sociedade na medida em que atua como tal, ou seja, subordinado ao equacionamento de suas atribuições, dentro dos limites de representação que dimanam da literalidade do objeto social estatutário e sob o enfoque finalístico do interesse social ${ }^{228}$.

Seguindo esse entendimento e baseado no regime de publicidade das sociedades anônimas, entende o autor que as sociedades não deveriam ser responsabilizadas por atos violadores da lei e dos estatutos:

O regime de publicidade das sociedades anônimas, baseado no arquivamento no Registro do Comércio de atos constitutivos e suas alterações, atas de assembléias gerais e de reuniões de conselho de administração e diretoria, associado à sua publicação, deve ser considerado a causa da irresponsabilidade da sociedade por atos praticados por administradores com violação do estatuto, pois presume-se que os terceiros contratantes conheçam a estrutura formal de poder de cada companhia, e a legitimação de seus respectivos representantes legais ${ }^{229}$.

Porém, tendo em vista que a verificação dos poderes dos administradores por meio do registro do comércio não é fácil e nem é um hábito do homem comum, o rigor de tal entendimento não pode ser absoluto. Nas palavras de TAVARES GUERREIRO:

O rigor de tal conclusão não deve, todavia, ser tomado em sentido absoluto, em nome do postulado que assegura proteção à boa fé de terceiros. A própria relação orgânica entre sociedade e administrador pode induzir, em determinadas hipóteses, a aparência do direito, cuja eficácia constitui um dos mais relevantes aspectos evolutivos da teoria jurídica. Saber-se se a sociedade se obriga por ato ultra vires praticado por diretor tende a ser uma determinação valorativa, em cada caso concreto, porquanto o erro do terceiro contratante há que ser avaliado em relação a um padrão médio de pessoa, de conhecimentos relativos. A obrigação contraída irregularmente pela sociedade com uma instituição financeira afeita à verificação dos poderes dos administradores intervenientes não pode evidentemente prevalecer, pois a constatação do excesso ultra vires não refugiria à esperada diligência da contratante. Mas, como bem notou Luiz Gastão Paes de Barros Leães, a verificação dos poderes dos diretores no Registro do Comércio não é fácil, nem entrou nos hábitos do homem comum. (...) Registra-se, no estágio atual do direito brasileiro, nítida tendência no sentido de configurar a

\footnotetext{
${ }^{227}$ EIZIRIK, Nelson. A Lei das S/A Comentada. vol. II. São Paulo: Quartier Latin, 2011. p. 400.

228 TAVARES GUERREIRO, José Alexandre. Responsabilidade dos Administradores de Sociedades Anônimas. Revista de Direito Mercantil, n. 42, abr./jun. 1981, p. 75.

229 Ibid., p. 75.
} 
responsabilidade da sociedade anônima pelas obrigações contraídas por administradores agindo com violação da lei ou do estatuto, quando o terceiro contraente se verifique estar de boa-fée $e^{230}$.

Vale citar, ainda sob esse aspecto, observação do próprio autor em conjunto com TEIXEIRA:

Afirmar que as limitações estatutárias prevalecem sempre e sem exceção, nas relações da sociedade com terceiros, seria criar, de certo modo, através de ampla presunção juris et de jure, entraves pesadíssimos à circulação econômica e proporcionar, quiçá, às sociedades menos escrupulosas uma poderosa válvula escapatória ${ }^{231}$.

Sendo assim, entende a maior parte da doutrina que a sociedade não responde pelos danos causados por administrador que agir com violação da lei ou do estatuto, exceto se: (i) tiver tirado proveito do ato; (ii) tiver ratificado o ato; ou (iii) o prejudicado for terceiro agindo de boa-fé ${ }^{232}$.

${ }^{230}$ Ibid., p. 75-77.

231 TEIXEIRA, Egberto Lacerda; TAVARES GUERREIRO, José Alexandre. Das Sociedades Anônimas no Direito Brasileiro. São Paulo: Bushatsky, 1979. p. 481.

${ }^{232}$ EIZIRIK, Nelson. A Lei das S/A Comentada. vol. II. São Paulo: Quartier Latin, 2011. p. 405; ADAMEK, Marcelo Vieira von. Responsabilidade Civil dos Administradores de S/A e as ações correlatas. São Paulo: Saraiva, 2009. p. 221-224; ZAITZ, Daniela. Responsabilidade dos Administradores de Sociedades Anônimas e por Quotas de Responsabilidade Limitada. Revista dos Tribunais. São Paulo: Revista dos Tribunais, $\mathrm{n}^{\circ}$ 740, jun. 1997, p. 32; TAVARES GUERREIRO, José Alexandre. Responsabilidade dos Administradores de Sociedades Anônimas. Revista de Direito Mercantil, n. 42, abr./jun. 1981, p. 76-77; LEÃES, Luiz Gastão Paes de Barros. Sociedade por ações atos praticados por seus diretores, em razão de administração - responsabilidade daquela e destes, solidariamente, se agiram com culpa ou contrariamente aos estatutos. Revista de Direito Mercantil, $\mathrm{n}^{\circ}$ 2, 1971. p. 80. 


\section{CAPÍTULO 4 - A BUSINESS JUDGMENT RULE}

Após a análise da administração de companhias, do processo de tomada de decisão dos administradores e do regime de responsabilidade desses profissionais no direito brasileiro, passe-se ao exame da business judgment rule. Uma vez contrapostos todos esses elementos, será possível verificar a importância dessa regra no cenário econômico, sua compatibilidade com o cenário da tomada de decisão, e o quão compatível ela é com o ordenamento jurídico nacional.

\subsection{Origem}

A primeira vez em que um tribunal se recusou a entrar no mérito de uma decisão empresarial se deu na Inglaterra, em 1742, no âmbito do julgamento do caso Charitable Corporation v. Sutton, em que, como expõe TREBILCOCK, os diretores de uma companhia de caridade teriam sido apontados pelos autores como culpados por não supervisionarem adequadamente as atividades de um depositário, que tinha como encargo conceder empréstimos a pessoas pobres ${ }^{233}$.

Nos Estados Unidos, o desenvolvimento da business judgment rule como um princípio jurisprudencial se iniciou em 1829, com o julgamento, pela Suprema Corte de Louisiana, do caso Percy v. Millaudon ${ }^{234}$. A corte entendeu que o modo correto para se determinar se um administrador é culpado se dá verificando-se se ele negligenciou em exercer o devido cuidado e diligência em suas funções ${ }^{235}$ :

The occurrence of difficulties (...) which offer only a choice of measures, the adoption of a course from which loss ensues cannot make the [director] responsible, if the error was one into which a prudent man might have fallen. The contrary doctrine seems to us to suppose the possession, and require the exercise of perfect wisdom in fallible beings. No man would undertake to render a service to another on such severe conditions (...). The test of responsibility, therefore, should be, not the certainty of

\footnotetext{
233 TREBILCOCK, M. J. The Liability of Company Directors for Negligence. The Modern Law Review. vol. 32, nº 5, set. 1969. p. 499.

${ }^{234}$ BLOCK, Dennis J.; BARTON, Nancy E.; RADIN, Stephen A. The Business Judgment Rule: Fiduciary Duties of Corporate Directors. 6 ed. v. I. New York: Aspen Publishers, 2009. p. 26.

235 Percy v. Millaudon, 8 Martin, (N.S.) 68, 74. Apud Briggs v. Spaulding, 141 U.S. 132 (1891)
} 
wisdom in others, but the possession of ordinary knowledge; and by showing that the error of the [director] is of so gross a kind that a man of common sense, and ordinary attention, would not have fallen into it ${ }^{236}$.

Em 1847, a Suprema Corte do Alabama explicitou o mesmo entendimento no caso Godbold v. Branch Bank, como expõe SILVA:

[Decidiu-se] que, apesar de devidamente informados e da legalidade dos atos praticados, se os administradores fossem responsabilizados por todos os atos praticados ou decisões errôneas na condução do negócio, sem a possibilidade de errar, nenhum homem prudente aceitaria o encargo de ser administrador sujeito a esse risco ${ }^{237}$.

Pouco tempo depois, nos anos de 1850 e 1853, a Suprema Corte de Rhode

Island proferiu decisões no âmbito do julgamento do caso Hodges v. New England Screw Co., afirmando que,

if (...) the mistake be such as the directors might well make, notwithstanding the exercise of proper care, and if they acted in good faith and for the benefit of the [corporation], they ought not to be liable238.

Passadas duas décadas, em 1872 e 1875, a Suprema Corte de Pensilvânia decidiu no mesmo sentido nas apelações Sperling's Appeal e Watt's Appeal ${ }^{239}$.

Finalmente, já no século XX, em 1912, a Corte de Apelações de Nova York julgou o caso Pollitz v. Wabash R.R. Co., expondo o entendimento de que algumas situações - uma lista exemplificativa - devem ser deixadas à discricionariedade dos administradores:

Questions of policy of management, expediency of contracts or action, adequacy of consideration, lawful appropriation of corporate funds to advance corporate interests, are left solely to their honest and unselfish decision, for their powers therein are without limitation and free from restraint, and the exercise of them for the common and general interests of the corporation may not be questioned, although the results show that what they did was unwise or inexpedient ${ }^{240}$.

\footnotetext{
${ }^{236}$ Percy v. Millaudon, 8 Mart, (n.s.) 68 (La. 1829). 77-78. Apud BLOCK, Dennis J.; BARTON, Nancy E.; RADIN, Stephen A. The Business Judgment Rule: Fiduciary Duties of Corporate Directors. 6 ed. vol. 1. New York: Aspen Publishers, 2009. p. 26.

${ }^{237}$ SILVA, Alexandre Couto. Responsabilidade dos Administradores de S/A: Business Judgment Rule. Rio de Janeiro: Elsevier, 2007. p. 141.

${ }^{238}$ Hodges v. New England Screw Co. 1 R.I. a 346. Apud BLOCK, Dennis J.; BARTON, Nancy E.; RADIN, Stephen A. The Business Judgment Rule: Fiduciary Duties of Corporate Directors. 6 ed. vol. 1. New York: Aspen Publishers, 2009. p. 27.

239 BLOCK, Dennis J.; BARTON, Nancy E.; RADIN, Stephen A. The Business Judgment Rule: Fiduciary Duties of Corporate Directors. 6 ed. vol. 1. New York: Aspen Publishers, 2009. p. 27.

${ }^{240}$ Pollitz v Wabash R. R. Co., 207 N.Y. 113, 124. Apud Auerbach v. Bennett, 47 N.Y.2d 619 (1979).
} 


\subsection{A regra}

A business judgment rule, a despeito de tentativas de codificação, foi, como visto acima, criada e desenvolvida exclusivamente pelas cortes inglesas e norte-americanas, tendo como principal pilar a presunção de que os administradores sempre atuam de boa-fé, diligentemente e no interesse da companhia.

BRANSON resume as principais características da regra, que serão expostas ao longo deste item:

The business judgment rule is multi-faceted. Most generally, the business judgment rule acts as a presumption in favor of corporate managers' actions. Stronger still, the rule provides a safe harbor that makes both directors and their actions unassailable if certain prerequisites have been met. In litigation, the rule is a means for conserving judicial resources, thereby permitting courts to avoid being mired down in rehashing decisions that are inherently subjective and ill suited for judges, as opposed to business men and women. Last of all, the rule is the law's implementation of broad economic policy, built upon economic freedom and the encouragement of informed risk taking ${ }^{241}$.

Cabe ressaltar, ainda, que a business judgment rule não pretende impor aos administradores um padrão de comportamento. Como coloca BAINBRIDGE, a regra pode ser vista como uma doutrina da abstenção, na medida em que o Poder Judiciário - e também do órgão regulador do mercado de capitais, como a CVM - devem se abster de revisar o mérito da decisão tomada:

(...) the business judgment rule can be seen as an abstention doctrine. In this conception, the rule's presumption of good faith does not state a standard of liability but rather establishes a presumption against judicial review of duty of care claims. The court therefore abstains from reviewing the substantive merits of the directors' conduct unless the plaintiff can rebut the business judgment rule's presumption of good faith ${ }^{242}$.

\subsubsection{A presunção}

A business judgment rule é uma presunção de que os administradores, no exercício de suas funções, sempre agem de boa-fé, diligentemente e no interesse

\footnotetext{
${ }^{241}$ BRANSON, Douglas M. The Rule That Isn't a Rule - The Business Judgment Rule Valparaiso University Law Review. vol. 36. $\mathrm{n}^{\circ}$ 3. p. 632.

242 BAINBRIDGE, Stephen M. The Business Judgment Rule as Abstention Doctrine. Vanderbilt Law Review. vol. 57, nº 1 , p. 90.
} 
da companhia. Assim observam BLOCK et al, citando diversos julgamentos norte-americanos:

The business judgment rule presumption that directors - including directors serving on board committees - are "faithful to their fiduciary duties" is "[a]t the foundation" and "[a]t the core of Delaware corporate law." The presumption is a "powerful," "strong" and "substantive" rule of the law, and not "merely a defense." 243

No mesmo sentido anota SILVA:

A business judgment rule é um conceito jurídico amplo de que os administradores têm a presunção de boa decisão ou julgamento do negócio, e essas decisões não estão afetadas se tomadas por uma proposta administrativa racional.

Presume-se que, em uma tomada de decisão, os administradores atuarão de boa-fé, devidamente informados e no interesse da companhia. Para rebater a presunção, o autor (acionista) assume a responsabilidade de provar que o Conselho de Administração quebrou qualquer uma das tríades dos deveres fiduciários: boa-fé, lealdade e diligência. Contrariamente, a business judgment rule protegerá os administradores e a decisão tomada $^{244 / 245}$.

O administrador, assim, deve tomar o cuidado de que o processo decisório

por ele adotado sempre observe todos os elementos da business judgment rule.

Caso contrário, a presunção de que ele agiu de boa-fé, diligentemente e no interesse da companhia perderá sua aplicabilidade.

\subsubsection{A não proteção de decisões irracionais}

Para que a presunção prevaleça, os tribunais norte-americanos vêm entendendo que a decisão tomada deve ter ao menos algum grau de racionalidade. Caso a decisão seja inexplicável do ponto de vista racional, ela não será protegida pela business judgment rule.

Como visto no caso Sinclair Oil Corporation v. Levien, "a board of directors enjoys a presumption of sound business judgment, and its

${ }^{243}$ BLOCK, Dennis J.; BARTON, Nancy E.; RADIN, Stephen A. The Business Judgment Rule: Fiduciary Duties of Corporate Directors. 6 ed. vol. 1. New York: Aspen Publishers, 2009. p. 40-42. Referências omitidas.

${ }^{244}$ SILVA, Alexandre Couto. Responsabilidade dos Administradores de S/A: Business Judgment Rule. Rio de Janeiro: Elsevier, 2007. p. 193.

${ }^{245}$ Cite-se, ainda, trecho da decisão proferida no âmbito do caso Aronson v. Lewis: "It is a presumption that in making a business decision the directors of a corporation acted on an informed basis, in good faith, and in the honest belief that the action taken was in the best interests of the company" 473 A.2d 805, 812 (Del. 1984). 
decisions will not be disturbed if they can be attributed to any rational business purpose" 246 .

Mas é importante compreender que irracionalidade não é o mesmo que irrazoabilidade. Decisões racionais, mesmo que irrazoáveis, serão protegidas pela business judgment rule, pois não cabe ao Poder Judiciário examinar e avaliar a razoabilidade de uma decisão negocial. Assim asseveram ALLEN, JACOBS e STRINE: "where the business judgment standard applies, a director will not be held liable for a decision - even one that is unreasonable - that results in a loss to the corporation, so long as the decision is rational"247.

A irracionalidade, como já colocou a Corte de Chancelaria de Delaware, se dá pela completa falta de razão, a ponto de não se ter como explicar o caminho percorrido pelo administrador para chegar à decisão tomada ${ }^{248}$. Em suas palavras, "the rule does not require the Court to bless the conclusion of a director that is self-evidently nonsense on stilts, nor does it protect a board that looks into the sun and names it the moon"249/250.

Deve-se focar, então, na racionalidade do processo decisório. A Suprema Corte de Delaware assim entendeu no julgamento do caso Brehm v. Eisner:

Courts do not measure, weigh or quantify directors' judgments. We do not even decide if they are reasonable in this context. Due care in the decisionmaking context is process due care only. Irrationality is the outer limit of the business judgment rule. Irrationality may be the functional equivalent of the waste test or it may tend to show that the decision is not made in good faith, which is a key ingredient of the business judgment rule $\mathrm{e}^{251 / 252}$.

\footnotetext{
246 Sinclair Oil Corporation v. Levien, 280 A.2d 717 (1971).

${ }^{247}$ ALLEN, William T.; JACOBS, Jack B.; STRINE, Leo E. Function Over Form: A Reassessment of Standards of Review in Delaware Corporation Law. The Business Lawyer. v. 56, ago. 2001. p. 1296.

${ }^{248}$ In Re infoUSA, Inc. Shareholders Litigation, 953 A.2d 963 (2007).

${ }^{249}$ In Re infoUSA, Inc. Shareholders Litigation, 953 A.2d 963 (2007).

${ }^{250}$ Seria o caso de uma decisão tão irracional que equivaleria ao desperdício de ativos da sociedade anônima. Conforme AMAN: "When plaintiffs challenge the substance of a board's decision, they must show that the decision was so irrational that is constituted a waste of assets" AMAN, Todd M. CostBenefit Analysis of the Business Judgment Rule: a Critique in Light of the Financial Meltdown. Albany Law Review. v. 74, 2010-2011. p. 9.

${ }^{251}$ Brehm v. Eisner, 746 A.2d 244 (2000).

${ }^{252}$ No mesmo sentido julgou-se o caso Paramount Communications v. QVC Network: "It is to be remembered that, in cases where the traditional business judgment rule is applicable and the board acted with due care, in good faith, and in the honest belief that they are acting in the best interests of the stockholders (which is not this case), the Court gives great deference to the substance of the directors'
} 
Portanto, como se entendeu no caso Brazen v. Bell Atlantic Corp., "Courts give deference to directors' decisions reached by a proper process, and do not apply an objective reasonableness test in such a case to examine the wisdom of the decision itself ${ }^{\prime 253}$.

\subsubsection{Os elementos da regra}

A business judgment rule é composta por quatro elementos: (i) ocorrência de uma decisão negocial; (ii) desinteresse e independência; (iii) diligência; e (iv) boa-fée ${ }^{254 / 255}$. Algumas cortes norte-americanas incluem, ainda, a inexistência de abuso de discricionariedade como um quinto elemento ${ }^{256}$, mas, como se verá oportunamente, não parece ser este elemento plenamente compatível com a regra em exame.

Uma vez observados todos esses elementos em seu processo decisório, o administrador não poderá ser responsabilizado pelos resultados de sua decisão. Se, contudo, agir sem observar um deles, a proteção da regra não se aplicará e o Judiciário poderá declará-lo responsável.

\subsubsection{Ocorrência de uma decisão negocial}

Na medida em que a business judgment rule é uma proteção conferida aos administradores para que os tribunais não entrem no mérito da decisão negocial por eles tomada, é necessário que haja pelo menos uma decisão desse tipo.

\footnotetext{
decision and will not invalidate the decision, will not examine its reasonableness, and will not substitute our views for those of the board if the latter's decision can be `attributed to any rational business purpose" Paramount Communications v. QVC Network, 637 A.2d 34 (1994).

${ }^{253}$ Brazen v. Bell Atlantic Corp., 695 A.2d 43 (1997).

${ }^{254}$ BLOCK, Dennis J.; BARTON, Nancy E.; RADIN, Stephen A. The Business Judgment Rule: Fiduciary Duties of Corporate Directors. 6 ed. vol. 1. New York: Aspen Publishers, 2009. p. 195.

${ }^{255}$ De acordo com a United States District Court de Nova York, "four elements define the business judgment rule presumption: (1) a business decision; (2) disinterestedness and independence; (3) due care; and (4) good faith" Roselink Investors, L.L.C. v. Shenkman, 386 F.Supp.2d 209 (2004).

${ }^{256}$ Como anotam BLOCK et al, o elemento inexistência de abuso de discricionariedade foi incluído somente por algumas cortes e doutrinadores: “(...) some courts and commentators have said that there also must not be any abuse of discretion" BLOCK, Dennis J.; BARTON, Nancy E.; RADIN, Stephen A. The Business Judgment Rule: Fiduciary Duties of Corporate Directors. 6 ed. vol. 1. New York: Aspen Publishers, 2009. p. 86.
} 
Nesse sentido entendeu a Suprema Corte de Delaware quando do julgamento do caso Aronson v. Lewis:

the business judgment rule operates only in the context of director action. Technically speaking, it has no role where directors have either abdicated their functions, or absent a conscious decision, failed to act. But it also follows that under applicable principles, a conscious decision to refrain from acting may nonetheless be a valid exercise of business judgment and enjoy the protections of the rule ${ }^{257}$.

As omissões, portanto, não são protegidas pela business judgment rule. Entretanto, é importante ressaltar, como apontado pela Suprema Corte de Delaware no trecho acima, que a decisão tomada pode ser uma decisão de não agir, o que não pode ser confundido com uma omissão. Conforme BRANSON, "a decision to make no decision is also a judgment or decision for purposes of the rule's application" $258 / 259$.

Um administrador pode entender, por exemplo, que os custos para a implementação de uma determinada política em sua companhia sejam muito altos e, por isso, não deva ser levado adiante. Essa é uma decisão - de não agir - e deve ser considerada como tal.

Mas, frise-se, a decisão deve ser negocial, isto é, deve tratar dos negócios da companhia. Assim explicam BLOCK et al:

The question whether a contract violates the law (for example, by precluding directors from meeting statutory and fiduciary obligations) is a question of law that does not fall into the realm of business judgment and cannot be definitively determined by the informed, good faith judgment of the board. As the name implies, a necessary predicate for the application of the business judgment rule is that the directors' decision be that of a business judgment and not a decision which construes and applies a statute and a corporate bylaw ${ }^{260}$.

\footnotetext{
${ }^{257}$ Aronson v. Lewis, 473 A.2d 805 (Del. 1984).

${ }^{258}$ BRANSON, Douglas M. The Rule That Isn't a Rule - The Business Judgment Rule Valparaiso University Law Review. vol. 36. $\mathrm{n}^{\circ} 3$. p. 639.

${ }^{259}$ De acordo com a Corte de Apelações de Indiana, no julgamento do caso Brane v. Roth, 590 N.E.2d 587 (1992), “(...) the rule does not protect directors who have abdicated their functions or absent a conscious decision, failed to act (...)".

${ }^{260}$ BLOCK, Dennis J.; BARTON, Nancy E.; RADIN, Stephen A. The Business Judgment Rule: Fiduciary Duties of Corporate Directors. 6 ed. vol. 1. New York: Aspen Publishers, 2009. p. 92.
} 


\subsubsection{Desinteresse e independência}

Como ensina EISENBERG, para cumprir com o elemento desinteresse e independência da business judgment rule, "the director or officer may not have a financial interest in the subject matter of the decision" ${ }^{261}$. Ou seja, o administrador não deve ter um interesse financeiro no assunto em que ele emitir alguma decisão, ele não pode estar presente nos dois lados de uma operação.

No mesmo sentido, GOLDBERG afirma o seguinte:

In order for a corporate decision to be protected by the business judgment rule, the majority of the involved directors must appear not to be on both sides of the transaction or to expect personal financial gain from the transaction. If the plaintiff challenging the board's decision cannot prove a lack of disinterestedness, the business judgment rule is then employed and the board's decision will be upheld by the court if no other element of the rule is violated ${ }^{262 / 263}$.

Os dois termos desse elemento, contudo, possuem significados distintos. Assim, é importante compreender a diferença entre os termos desinteresse e independência.

Como se mostrou no caso Beam v. Stewart, o interesse de um administrador é comprovado pela demonstração de que este possui um potencial benefício ou prejuízo com o resultado da decisão a ser tomada ${ }^{264}$. Mostrará desinteresse, desse modo, aquele que estiver pessoalmente alheio às consequências de sua decisão.

O mesmo se entendeu no julgamento de Aronson v. Lewis:

(...) its [a corte se refere à business judgment rule] protections can only be claimed by disinterested directors whose conduct otherwise meets the tests of business judgment. From the standpoint of interest, this means that directors can neither appear on both

\footnotetext{
${ }^{261}$ EISENBERG, Melvin Aron. The Divergence of Standards of Conduct and Standards of Review in Corporate Law. Fordham Law Review. vol. 62, 1993, p. 441.

${ }^{262}$ GOLDBERG, Mindy K. How Much Information is Enough. Journal of Law and Commerce, vol. 7, p. 228.

${ }^{263}$ A esse respeito, veja-se o seguinte comentário oficial à Seção 8.31 do Revised Model Business Corporation Act: "If a director has a familial, financial or business relationship with another person having a material interest in a transaction or other conduct involving the corporation, or if the director is dominated or controlled by another person having such a material interest, there is a potential for that conflicted interest or divided loyalty to affect the director's judgment" Revised Model Business Corporate Act. Comentário Oficial à Seção 8.31.

${ }^{264}$ Beam v. Stewart, 845 A.2d 1040 (2004).
} 
sides of a transaction nor expect to derive any personal financial benefit from it in the sense of self-dealing, as opposed to a benefit which devolves upon the corporation or all stockholders generally ${ }^{265}$.

Conforme voto da diretora Ana Dolores de Novaes, no âmbito do Processo Administrativo Sancionador CVM nº 09/2006,

"Interesse" (...) são os desejos que qualquer pessoa tenha em obter bens e serviços tangíveis e intangíveis, como também o status social decorrente da posição ocupada pelo indivíduo ${ }^{266}$.

Já sobre o termo independência, BLOCK et al explicam, com base no caso Aronson v. Lewis, que 'the term 'independence' means that a director's decision is based on the corporate merits of the subject before the board rather than extraneous considerations or influences" 267.

Esse entendimento também foi exposto no julgamento do caso In re infoUSA, Inc. Shareholders Litigation:

A plaintiff may (...) challenge a director's independence by putting forward allegations that raise a reasonable inference that a given director is dominated through a close personal or familial relationship or through force of will, or is so beholden to an interested director that his or her discretion would be sterilized. To demonstrate that a given director is beholden to a dominant director, plaintiffs must show that the beholden director receives a benefit upon which the director is so dependent or is of such subjective material importance that its threatened loss might create a reason to question whether the director is able to consider the corporate merits of the challenged transaction objectively ${ }^{268}$.

Em resumo, “o administrador não será independente”, como afirma BLOK, "quando for dominado ou controlado por credor ou pessoa jurídica ou natural interessada na conduta ou na transação que possa influenciar sua capacidade de discricionariedade" ${ }^{269}$. Para ser considerado interessado, o

\footnotetext{
${ }^{265}$ Aronson v. Lewis, 473 A.2d 805 (1984). Na mesma direção a Suprema Corte de Delaware decidiu o caso Pogostin v. Rice, 480 A.2d 619 (1984): "Directorial interest exists whenever divided loyalties are present, or a director either has received, or is entitled to receive, a personal financial benefit from the challenged transaction which is not equally shared by the stockholders".

266 Processo Administrativo Sancionador CVM nº 09/2006, Rel. Ana Dolores Moura Carneiro de Novaes, j. em 5 mar. 2013.

${ }^{267}$ BLOCK, Dennis J.; BARTON, Nancy E.; RADIN, Stephen A. The Business Judgment Rule: Fiduciary Duties of Corporate Directors. 6 ed. vol. 1. New York: Aspen Publishers, 2009. p. 100. Aspas de citação omitidas.

${ }^{268}$ In re infoUSA, Inc. Shareholders Litigation, 953 A.2d 985. Aspas de citações omitidas.

${ }^{269}$ BLOK, Marcella. Business Judgment Rule: a responsabilidade dos administradores das sociedades anônimas. Revista de Direito Bancário e do Mercado de Capitais. vol. 46. out. 2009. p. 145.
} 
administrador deve se beneficiar financeiramente ou de outro modo fortemente estabelecido, como, por exemplo, perpetuar os membros do conselho de administração em seus $\operatorname{cargos}^{270}$.

\subsubsection{Diligência}

Para serem protegidos pela business judgment rule, os administradores devem atuar de maneira informada quando da tomada de decisões. Como escreve BLOK, "o dever de diligência na Business Judgment Rule está relacionado especificamente com a atuação do administrador com a devida informação sobre a matéria a ser decidida" 271 .

Dessa forma, LOWENTHAL explica que “(...) a finding of breach of the duty of care requires evidence of a director's failure to have exercised an informed business judgment" ${ }^{272}$. Ressalte-se, no entanto, que não se exige do administrador que ele conheça todos os fatos e informações que envolvem uma decisão, mas tão-somente aqueles - e todos aqueles - que forem relevantes e razoavelmente acessíveis ${ }^{273}$.

O administrador será responsabilizado, então, se agir com negligência grave (gross negligence), conceito tratado pela Corte de Chancelaria de Delaware no julgamento do caso In Re Walt Disney Co. Derivative Litigation:

\footnotetext{
${ }^{270}$ Ibid., p. 145. A autora ainda aponta que, "para desqualificar o administrador, o interesse deve ser substancial ou material, não bastando ser simplesmente incidental ou circunstancial”.

${ }^{271}$ Ibid., p. 145.

${ }^{272}$ LOWENTHAL, Andrea. Corporate takeovers and the business judgment rule: the second circuit puts targets corporations on the auction block. Brooklyn Law Review. Nova York. v. 53. n 2, summ. 1987. p. 424.

${ }^{273}$ Como se pode ver no julgamento do caso Brehm v. Eisner, 746 A.2d 244 (2000), “(...) the standard for judging the informational component of the directors' decisionmaking does not mean that the Board must be informed of every fact. The Board is responsible for considering only material facts that are reasonably available, not those that are immaterial or out of the Board's reasonable reach". Para fins de esclarecimento, a Suprema Corte de Delaware afirma que "the term 'material' is used in this context to mean relevant and of a magnitude to be important to directors in carrying out their fiduciary duty of care in decisionmaking. In this sense, it is distinct from the use of the term 'material' in the quite different context of disclosure to stockholders in which an omitted fact is material if there is a substantial likelihood that a reasonable shareholder would consider it important in deciding how to vote" (aspas de citação omitidas).
} 
In the duty of care context with respect to corporate fiduciaries, gross negligence has been defined as a reckless indifference to or a deliberate disregard of the whole body of stockholders' or actions which are "without the bounds of reason"274.

BRANSON, nessa linha, explica que o administrador não deve exercer alguma diligência, mas, sim, a devida diligência:

More astute courts recognize that the business judgment rule does not protect complete absences of care. Directors completely asleep at the switch do not enjoy the rule's protection. They must go to trial where they will have to establish that they exercised not only some care, but due care ${ }^{275}$.

Assim, como expõe HANSEN, a diligência que se espera de um administrador no direito societário e de mercado de capitais não é idêntica àquela do direito civil.

De acordo com o autor, no direito civil, o padrão aplicado é orientado pelo resultado, isto é, verifica-se se a conduta do devedor teria sido correspondente àquela de uma pessoa razoável diante das mesmas circunstâncias. No direito societário, o padrão é outro; o administrador será diligente se tiver se informado antes de tomar uma decisão ${ }^{276}$.

Assim, o foco do Poder Judiciário e do órgão regulador do mercado de capitais, quando da análise de uma decisão negocial, deve ser não o mérito da decisão, mas, sim, o processo decisório pelo qual passou o administrador. Em outras palavras, a preocupação do julgador deve se dar com a conduta que o administrador adotou para chegar à decisão tomada, verificando-se se ele reuniu informações suficientes para embasar o seu comportamento.

SILVA, nessa linha, anota que "o dever de diligência foca no processo de tomada de decisão com análise de possibilidades e alternativas, bem como na identificação da matéria em questão"277.

\footnotetext{
${ }^{274}$ In Re Walt Disney Co. Derivative Litigation, 907 A.2d 693 (2005).

275 BRANSON, Douglas M. The Rule That Isn't a Rule - The Business Judgment Rule. Valparaiso University Law Review. vol. 36, n 3, p. 646.

${ }^{276}$ HANSEN, Charles. The Duty of Care, the Business Judgment Rule, and the American Law Institute Corporate Governance Project. In: Business Lawyer. v. 48, 1992-1993. p. 1357-1358.

277 SILVA, Alexandre Couto. Responsabilidade dos Administradores de S/A: Business Judgment Rule. Rio de Janeiro: Elsevier, 2007. p. 200.
} 


\subsection{Mas quanta informação é necessária?}

Como visto acima, o administrador não receberá a proteção da business judgment rule se não adquirir e analisar todas as informações relevantes que estiverem razoavelmente ao seu alcance. Contudo, quantas e quais informações são necessárias para um negócio? E a quem cabe decidir isso?

Como observa GOLDBERG, já houve tentativas de se objetivar a quantidade de informações a serem reunidas em cada caso, mas as definições sugeridas eram muito abstratas e não houve sucesso:

Both the Model Business Corporation Act (MBCA) and the American Law Institute (ALI) have attempted to address this problem in their codifications of the business judgment rule, albeit inadequately. In the 1985 ALI Draft on Corporate Governance, a director must act as an ordinary person would act in like circumstances. The ALI draft also requires directors to be "informed with respect to the subject of his business judgment to the extent he reasonably believes to be appropriate under the circumstances." The MBCA also refers to the standard of care as that of an ordinary prudent person in like circumstances. Once again, as with the aforementioned judicial opinions, a standard of care was set forth in the above codifications without a clear definition of what actions would fall short of meeting this standard ${ }^{278}$.

Evidentemente, a quantidade de informações necessárias à tomada de decisão varia de acordo com as peculiaridades do caso concreto. Além disso, em muitos casos, a demora com a coleta de informações adicionais pode representar um custo equivalente ou maior do que aquele resultante de um suposto dano causado pela decisão menos informada.

Visando a solucionar a questão, GOLDBERG propõe um teste a ser usado pelos tribunais para avaliar se a decisão tomada foi ou não devidamente informada ${ }^{279}$. Ela divide o teste em duas fases: uma subjetiva e outra, posterior, objetiva.

${ }^{278}$ GOLDBERG, Mindy K. How Much Information is Enough. Journal of Law and Commerce, vol. 7, p. 231-232.

${ }^{279}$ Veja-se, em suas palavras, a descrição do teste por ela elaborado: "Although judicial opinions discussing the 'informed' prong of the business judgment rule have not yet developed a test to use in its analysis, a reading of the cases indicates that the creation of such a test is possible. Specifically, the 'informed' prong of the business judgment rule can be seen as a subjective test with an outer boundary of objectiveness.

When faced with a question of whether a board's decision was an informed one, the court should subjectively consider all factors surrounding the challenged decision. These factors should be used to 
Na fase subjetiva, o Poder Judiciário, levando em conta a magnitude da decisão tomada, deverá considerar subjetivamente todos os fatores a ela ligados. Tais fatores, então, seriam usados para determinar quanta informação seria necessária para qualificar uma decisão informada.

Reunidos os fatores, o Judiciário considerará o lapso de tempo disponível aos administradores para adquirir as informações relevantes. Em seguida, serão considerados os custos relacionados à aquisição de todas essas informações e a credibilidade de quem as forneceu (como especialistas e funcionários da companhia).

Posteriormente, o tribunal considerará o status do negócio da companhia ao tempo da decisão e a natureza das demandas competitivas que chamam a atenção do administrador.

Enfim, na fase objetiva, verificar-se-á se um administrador ordinário e prudente em circunstâncias semelhantes teria atuado da mesma forma que o administrador cuja decisão está sob análise. A quantidade de informações necessárias seria então identificada.

Mas será esse teste realmente eficiente para se determinar quanta informação é necessária a cada caso? Por meio dele, os tribunais deveriam analisar (i) quais são os fatores relevantes ligados a uma decisão; (ii) se o tempo

determine just how much information would have been required in order for the board's decision-makers to be considered 'informed.' These factors include the magnitude of the decision to be made. For example, a question of whether to approve a merger obviously would require more information than deciding whether to add a new management department in the corporation. The court should then consider the timeframe available to the directors for acquiring the information prior to the time the decision was to be made. As a next step, the court should consider the costs related to obtaining all relevant information. Next, the court should consider the credibility of the people who give the information to the decision-makers. These people include both experts and corporate employees. If the credibility is high, directors are more justified in relying on the information given even if it is later proved mistaken. Finally, the court should consider the state of the corporation's business at the time the decision was made and the nature of competing demands of the directors' attention. In other words, if more pressing issues were at hand at the time the challenged decision was made, the amount of effort needed to be put forth to acquire the information should be less. After this type of subjective reasoning is completed, the court should then apply a parameter of objectiveness. The question then to be answered would be whether an ordinary prudent 'director' in like circumstances would have acted in the fashion taken when the directors made the challenged decision. If the answer to this question is yes, the court should find that the due care element of the business judgment rule has been satisfied, and the directors should not be found liable absent other questionable behavior" Ibid., p. 241-242. 
que o administrador tem para tomá-la é curto, razoável ou longo; (iii) quais os custos para se adquirir todas as informações relacionadas aos fatores relevantes; (iv) a credibilidade de quem forneceu as informações; e (v) a situação financeira em que se encontra a companhia no momento da tomada de decisão. Após isso, comparariam a conduta sob exame com aquela de um administrador ordinário e prudente em situação semelhante.

Ora, considerando-se que não são especialistas na administração de companhias, será que os magistrados são capazes de analisar todos esses pontos de maneira justa e razoável? Analisar quais os fatores relevantes ligados a uma decisão, ou se os custos para adquirir as informações são altos ou baixos não são tarefas intimamente ligadas à atividade de administração de companhias? As respostas parecem ser não e sim, respectivamente.

Deve-se ter em mente, nesse sentido, que definir quanta informação é o suficiente para cada tomada de decisão também é uma decisão negocial a ser tomada pelo administrador. Somente ele é capaz de determinar se, diante de todos os custos e peculiaridades de cada caso, é válido considerar a quantidade de informações já detida o suficiente ou se é necessário ir atrás de mais informações ${ }^{280}$.

Assim, como apontado por BLOK, “(...) não é fácil para o Judiciário analisar o que seja 'decisão informada' e a mensuração do dever de diligência" ${ }^{281}$. Por isso, como entende SILVA, "a quantidade de informação necessária ou requerida para a tomada de decisão também é um julgamento ou

\footnotetext{
${ }^{280}$ De acordo com CAMPOS: "Evidentemente, a questão da decisão informada precisa ser compreendida com um grão de sal, já que o nível de informação necessária dependerá, entre outros fatores, do conhecimento prévio relacionado ao assunto objeto de apreciação detido por cada administrador, a quantidade de informação disponível, o custo da obtenção de mais informações, o tempo necessário para se produzir a informação, a necessidade e premência para se decidir" CAMPOS, Luiz Antonio de Sampaio. Deveres e Responsabilidades. In: LAMY FILHO, Alfredo; PEDREIRA, José Luiz Bulhões (Org.). Direito das Companhias. Rio de Janeiro: Forense, 2009. p. 1106.

${ }^{281}$ BLOK, Marcella. Business Judgment Rule: a responsabilidade dos administradores das sociedades anônimas. Revista de Direito Bancário e do Mercado de Capitais. vol. 46. out. 2009. p. 146.
} 
decisão empresarial" e, então, configura-se como uma “decisão sujeita à business judgment rule" 282 .

BRANSON vai no mesmo sentido:

One noted commentator has urged that the standard to be applied should be a subjective standard. That is, did the directors making the decision reasonably believe that they possessed sufficient information? An alternative phrasing that asks how much information is enough information, or what information gathering mechanisms (consultants, committees, reports) are sufficient, is itself a matter of business judgment ${ }^{283}$.

\subsubsection{Boa-fé}

A business judgment rule não protege decisões tomadas de má-fé. De acordo com BLOCK et al, “(...) whether or not there is a duty of good faith separate from the duties of care and loyalty, good faith is a prerequisite and key ingredient of the business judgment rule" 284 . O motivo disso, para os autores, é o fato de que a regra presume que os administradores atuam acreditando honestamente que o fazem em prol dos interesses da companhia ${ }^{285}$.

No entanto, em algumas decisões, o elemento boa-fé foi aplicado de uma maneira pela qual os tribunais acabam entrando no mérito das decisões. Nesses casos, a má-fé se mostrou presente e derrubou a presunção da business judgment rule porque, segundo os juízes, a decisão sob análise teria extrapolado os limites da razoabilidade e se mostrado inexplicável.

Assim, por exemplo, julgou-se o caso In Re J.P. Stevens \& Co., Inc.:

A court may, however, review the substance of a business decision made by an apparently well motivated board for the limited purpose of assessing whether that decision is so far beyond the bounds of reasonable judgment that it seems essentially inexplicable on any ground other than bad faith ${ }^{286 / 287}$.

\footnotetext{
282 SILVA, Alexandre Couto. Responsabilidade dos Administradores de S/A: Business Judgment Rule. Rio de Janeiro: Elsevier, 2007. p. 200.

${ }^{283}$ BRANSON, Douglas M. The Rule That Isn't a Rule - The Business Judgment Rule. Valparaiso University Law Review. vol. 36, nº 3, p. 640.

${ }^{284}$ BLOCK, Dennis J.; BARTON, Nancy E.; RADIN, Stephen A. The Business Judgment Rule: Fiduciary Duties of Corporate Directors. 6 ed. vol. 1. New York: Aspen Publishers, 2009. p. 330. Aspas de citação omitidas.

${ }^{285}$ Ibid., p. 330.

${ }^{286}$ In Re J.P. Stevens \& Co., Inc., 542 A.2d 770 (1988).

${ }^{287}$ No mesmo sentido, Parnes v. Bally Entertainment Corp., 722 A.2d 1243 (1999).
} 
A boa-fé, nessa linha de raciocínio, se associa tanto ao desconhecimento sem culpa quanto às decisões racionalmente explicáveis, ao passo que a má-fé está ligada ao contrário desses $\operatorname{conceitos}^{288}$. A partir disso, SILVA conclui:

Se a conduta for entendida como deficiente nos fundamentos, o processo de tomada de decisão - que está fora dos limites da razoabilidade do julgamento - dará a inferência de má-fé289.

Esse aspecto da boa-fé, contudo, não parece ser compatível com os princípios da business judgment rule, uma vez que, para verificar a má-fé, o juiz deveria entrar no mérito da decisão e dizer, ele mesmo, se ela é razoável ou minimamente explicável.

E, considerando que juízes não são especialistas em administração de empresas, os limites da razoabilidade e racionalidade por eles adotados podem ser bem diferentes daqueles utilizados pelos administradores. Dessa forma, entende-se que o parâmetro mais adequado para determinar uma conduta pautada pela má-fé estaria ligado à existência da intenção em causar prejuízos à companhia.

Nesse sentido, a Corte de Chancelaria de Delaware emitiu importante decisão no âmbito do caso In re Walt Disney Co. Derivative Litigation, em que a The Walt Disney Company celebrou um acordo de rescisão contratual sem justa causa no valor de 140 milhões de dólares com Michael Ovitz, um empregado admitido apenas um ano antes.

Como se verá no trecho abaixo, três aspectos do elemento boa-fé foram levantados no julgamento desse caso: (i) dolo; (ii) falha escandalosa no processo decisório; e (iii) indiferença consciente quanto aos negócios da companhia:

It is of course true that after-the-fact litigation is a most imperfect device to evaluate corporate business decisions, as the limits of human competence necessarily impede judicial review. But our corporation law's theoretical justification for disregarding honest errors simply does not apply to intentional misconduct or to egregious process failures that implicate the foundational directoral obligation to act honestly and in good

${ }^{288}$ SILVA, Alexandre Couto. Responsabilidade dos Administradores de S/A: Business Judgment Rule. Rio de Janeiro: Elsevier, 2007. p. 203.

289 Ibid., p. 207. 
faith to advance corporate interests. Because the facts alleged here, if true, portray directors consciously indifferent to a material issue facing the corporation, the law must be strong enough to intervene against abuse of trust ${ }^{290}$.

E, como se constatou no mencionado caso, "the defendant directors knew that they were making material decisions without adequate information and without adequate deliberation" e, mesmo assim, "they simply did not care if the decisions caused the corporation and its stockholders to suffer injury or loss" 291 .

Portanto, os elementos diligência e boa-fé se diferenciam na medida em que a conduta danosa se deu conscientemente. Enquanto aquele elemento se refere a condutas negligentes, em que o administrador não se informou o suficiente para se dar conta dos perigos de sua decisão, este guarda relação com comportamentos intencionais, em que o administrador executa uma decisão mesmo conhecendo os danos que serão sofridos por conta dela.

\subsubsection{Inexistência de abuso de discricionariedade, um quinto elemento?}

Como já dito, algumas cortes norte-americanas incluem a inexistência de abuso de discricionariedade como um quinto elemento da business judgment rule. De acordo com elas, não serão protegidas por essa regra as decisões que forem consideradas irrazoáveis e insensatas para os negócios da companhia.

Assim entendeu, por exemplo, a Corte de Apelações dos Estados Unidos:

(...) where the shareholder contends that the directors' judgment is so unwise or unreasonable as to fall outside the permissible bounds of the directors' sound discretion, a court should, we think, be able to conduct its own analysis of the reasonableness of that business judgment ${ }^{292}$.

Seguindo esse raciocínio, mesmo tendo sido tomada de forma desinteressada, independente, diligente e de boa-fé, a decisão poderá ser revisada pelo julgador na hipótese em que houver abuso de discricionariedade do

\footnotetext{
${ }^{290}$ In re Walt Disney Co. Derivative Litigation, 825 A.2d 275 (2003).

${ }^{291}$ In re Walt Disney Co. Derivative Litigation, 825 A.2d 275 (2003).

${ }^{292}$ Cramer v. General Tel. \& Electronics Corp., 582 F.2d 259 (1978).
} 
administrador $^{293}$. E a caracterização do abuso de discricionariedade se dará face a uma conduta que, de tão insensata ou irrazoável, equivalerá a um abuso por parte do administrador.

Porém, indaga-se se esse elemento não iria contra os próprios princípios da business judgment rule. Isto é, o Judiciário, para determinar se uma decisão é irrazoável ou insensata, não acaba sendo obrigado a analisar a própria decisão em si, entrando no seu mérito? Caso a decisão tenha respeitado todos os outros elementos da regra, isso não faria sentido.

Foi o que concluiu a Corte de Chancelaria de Delaware, no julgamento do caso In re Caremark International Inc. Derivative Litigation, em que se dá ênfase ao processo que levou à tomada de decisão, e não à decisão em si:

What should be understood, but may not widely be understood by courts or commentators who are not often required to face such questions, is that compliance with a director's duty of care can never appropriately be judicially determined by reference to the content of the board decision that leads to a corporate loss, apart from consideration of the good faith or rationality of the process employed. That is, whether a judge or jury considering the matter after the fact, believes a decision substantively wrong, or degrees of wrong extending through "stupid" to "egregious" or "irrational", provides no ground for director liability, so long as the court determines that the process employed was either rational or employed in a good faith effort to advance corporate interests. To employ a different rule-one that permitted an "objective" evaluation of the decision-would expose directors to substantive second guessing by ill-equipped judges or juries, which would, in the long-run, be injurious to investor interests. Thus, the business judgment rule is process oriented and informed by a deep respect for all good faith board decisions ${ }^{294}$.

Sendo assim, adotando-se a posição da Corte de Chancelaria de Delaware exposta no caso Caremark, conforme trecho acima, a inexistência de abuso de discricionariedade não será considerada como um elemento da business judgment rule para fins do presente trabalho.

${ }^{293}$ BLOCK, Dennis J.; BARTON, Nancy E.; RADIN, Stephen A. The Business Judgment Rule: Fiduciary Duties of Corporate Directors. 6 ed. vol. 1. New York: Aspen Publishers, 2009. p. 371.

${ }^{294}$ In re Caremark International Inc. Derivative Litigation, 698 A.2d 959 (1996). 


\title{
4.2.4 Tentativas de codificação
}

A partir do início da década de 1980, organizações norte-americanas como a American Bar Association e o American Law Institute, realizaram tentativas (mal sucedidas) de codificação da business judgment rule, como se vê no Model Business Corporation Act e no Principles of Corporate Governance: Analysis and Recommendations.

\subsubsection{O Model Business Corporation Act}

A American Bar Association elaborou o Model Business Corporation Act, documento designado para ser um modelo claro e preciso para a revisão das legislações estaduais ${ }^{295}$. Em 1984, esse documento foi inteiramente revisado pelo Comitê de Direito Societário da mencionada associaçãa ${ }^{296}$, tendo a business judgment rule recebido mais atenção do que qualquer outro instituto ${ }^{297}$. Gerouse, assim, o Revised Model Business Corporation Act, que previu a regra em sua Seção 8.30.

Contudo, o próprio comitê concluiu que não se tratava de uma codificação da regra, pois sua definição seria tarefa dos tribunais:

\begin{abstract}
Long before statutory formulations of directors' standards of conduct, courts would invoke the business judgment rule in evaluating directors' conduct and determining whether to impose liability in a particular case. The elements of the business judgment rule and the circumstances for its application are continuing to be developed by the courts. Section 8.30 does not try to codify the business judgment rule or to delineate the differences between that defensive rule and the section's standards of director conduct. Section 8.30 deals only with standards of conduct the level of performance expected of every director entering into the service of a corporation and undertaking the role and responsibilities of the office of director ${ }^{298}$.
\end{abstract}

\footnotetext{
295 BLOCK, Dennis J.; BARTON, Nancy E.; RADIN, Stephen A. The Business Judgment Rule: Fiduciary Duties of Corporate Directors. 6 ed. vol. 1. New York: Aspen Publishers, 2009. p. 403.

${ }^{296}$ Chamado, em inglês, de Committee on Corporate Laws of the Section of Business Law of the American Bar Association.

297 Ibid., p. 404.

${ }^{298}$ Revised Model Business Corporate Act. Comentário Oficial à Seção 8.30.
} 
Em 1999, o Comitê de Direito Societário do American Bar Association realizou outra revisão à Seção 8.30. SILVA bem resume as conclusões de tal comitê:

Após a revisão de 1999, concluiu-se que a regra do business judgment seria um conceito amplo da common law e as decisões dos administradores teriam a presunção de ser corretas, bem como não seriam atacadas pelo Judiciário se a elas fosse atribuído o racional do propósito do negócio da companhia. (...) Pelo fato de os elementos da business judgment rule e a circunstância da aplicação estarem em contínuo desenvolvimento pelo Judiciário, não seria desejável congelar o conceito em lei ${ }^{299}$.

\subsubsection{Principles of Corporate Governance: Analysis and Recommendations}

Paralelamente à elaboração do Model Business Corporation Act, o American Law Institute criou o projeto de governança corporativa chamado Principles of Corporate Governance: Analysis and Recommendations. A business judgment rule foi prevista na Seção 4.01(c) desse projeto, a seguir:

A director or officer who makes a business judgment in good Faith fulfills the duty under this Section if the director or officer:

(1) is not interested in the subject of his business judgment;

(2) is informed with respect to the subject of his business judgment to the extent he reasonably believes to be appropriate under the circumstances; and

(3) rationally believes that his business judgment is in the best interests of the corporation $^{300}$.

Tal projeto, então, não prevê a business judgment rule como uma presunção. De acordo com sua redação, o administrador deve preencher os todos os requisitos citados acima para ser protegido pela regra, não se presumindo, portanto, a sua atuação como de boa-fé e no interesse da companhia.

Assim como o Model Business Corporation Act, os Principles of Corporate Governance também não receberam aprovação total por parte dos

\footnotetext{
${ }^{299}$ SILVA, Alexandre Couto. Responsabilidade dos Administradores de S/A: Business Judgment Rule. Rio de Janeiro: Elsevier, 2007. p. 145.

3001 Principles of Corporate Governance: Analysis and Recommendations, §4.01(c), 1994. Apud BLOCK, Dennis J.; BARTON, Nancy E.; RADIN, Stephen A. The Business Judgment Rule: Fiduciary Duties of Corporate Directors. 6 ed. vol. 1. New York: Aspen Publishers, 2009. p. 409.
} 
tribunais norte-americanos, que continuaram aplicando e definindo a business judgment rule com base no julgamento de casos concretos.

\subsection{As razões da regra}

Como já visto, os acionistas de uma companhia esperam que os administradores busquem o desenvolvimento de seus negócios, seja por meio da inovação, seja por meio da incorporação de outra sociedade, seja por qualquer outro meio lícito. A atividade de administração de companhias, por isso, está necessária e intimamente ligada à tomada de riscos, pois, sem ele, o desenvolvimento e o lucro são impossíveis ${ }^{301}$.

Mas, tendo em vista que o futuro não é previsível e que o mercado pode, por si só, converter o sucesso de um investimento em um prejuízo inestimável ${ }^{302}$, o caminho tomado pelos administradores para satisfazer os interesses dos acionistas nem sempre se mostrará o mais eficiente depois que revelados os resultados de suas decisões. O risco, apesar de essencial, nem sempre traz bons resultados.

Ilustrando a atividade arriscada de administração de sociedades empresariais, BLACK narra o caso de uma companhia cuja estratégia negocial inclui gastos de dez bilhões de dólares para construir diversas fábricas e vender produtos que ainda não foram desenvolvidos para consumidores que ainda não possui $^{303}$. A estratégia da companhia, segundo ele, só terá sucesso se o mercado crescer $30 \%$ no ano e seus engenheiros solucionarem múltiplas dificuldades técnicas e transformarem o planejamento de novos produtos em produtos reais que possam ser produzidos em massa e em um tempo razoável.

\footnotetext{
${ }^{301}$ Como visto no item 2.3 desta monografia.

302 Tem-se como exemplo claro dessa afirmativa o caso Sadia (Processo Administrativo Sancionador CVM no 18/08, rel. Alexsandro Broedel Lopes, j. em 14 dez. 2010), em que os investimentos em derivativos, que um dia chegaram a representar receitas maiores do que o próprio exercício do objeto social da companhia, a levaram a prejuízos extraordinários.

${ }^{303}$ BLACK, Bernard S. The Core Fiduciary Duties of Outside Directors. Asia Business Law Review, $\mathrm{n}^{\circ}$ 3-16, jul. 2001. p. 16-17.
} 
Se a operação for bem sucedida, ela será reproduzida em escala maior no ano seguinte. Caso contrário, as fábricas construídas tornar-se-ão ociosas e seus equipamentos, obsoletos em cinco anos. $\mathrm{O}$ diretor executivo da companhia, em entrevistas publicadas na imprensa, descrevia essa estratégia como se estivesse dirigindo um carro a 150 quilômetros por hora ao longo de uma sinuosa estrada de montanha, no escuro, com as luzes apagadas e tentando não bater.

BLACK, assim, afirma que "this strategy is guaranteed to crash sooner or later. The company's managers just don't know when"304. E questiona:

\begin{abstract}
When the crash comes, do we want a judge to look at this strategy and the CEO's explanation, and hold the directors personally liable for the damage? If we are ever going to hold directors liable for negligence, this seems like a strong case for doing so. Or do we want to allow directors to take wild risks, in the hope of achieving wild success $^{305}$ ?
\end{abstract}

Há uma reviravolta no caso. A companhia mencionada por BLACK é a Intel, "which is one of the world's most successful companies"306. O diretor executivo ao volante do carro a 150 quilômetros por hora no escuro é Andrew Grove. A Intel, segundo BLACK, de fato perdeu o controle no ano de 2000. Era, de acordo com ele, uma questão de quando isso aconteceria, e não se aconteceria ${ }^{307}$. Mas, em suas palavras, "Intel is still a big, successful company, and long-term investors are very happy with their investment" ${ }^{308}$.

Visto isso, será que seria justo e razoável um juiz entrar no mérito da decisão de Grove e responsabilizá-lo pelos prejuízos causados, mesmo em se tratando de uma decisão tomada honestamente? A Intel é uma das maiores companhias do mundo e seu desenvolvimento certamente se deu - e se dá - por conta de decisões arriscadas como a acima descrita.

Um ambiente jurídico hostil à tomada de riscos, que pune erros negociais cometidos de boa-fé e no interesse da companhia, faria com que toda a lógica da

\footnotetext{
${ }^{304}$ Ibid., p. 17.

305 Ibid., p. 17.

306 Ibid., p. 17.

${ }^{307}$ Ibid., p. 17.

${ }^{308}$ Ibid., p. 17.
} 
administração de sociedades perdesse o sentido. Pessoas probas e honestas deixariam de exercer essa atividade e os administradores restantes desempenhariam suas funções buscando, antes de qualquer coisa, a sua não responsabilização pessoal por prejuízos causados à companhia.

A business judgment rule visa, então, a proteger administradores que cometem erros honestamente com a certeza de que os ganhos de uma segunda análise da decisão por parte do Judiciário são muito pequenos, ao passo que os ganhos com a tomada de riscos podem ser imensuráveis.

A regra, assim, se baseia em cinco pilares: (i) a imputação de responsabilidade por erros honestamente cometidos afastaria profissionais competentes da administração de companhas; (ii) administradores devem ser encorajados a tomar riscos; (iii) juízes não são especialistas em negócios; (iv) as companhias são geridas por administradores, e não por acionistas; e (v) se estiverem insatisfeitos com a administração, os acionistas podem desconstituir e substituir os administradores.

\subsubsection{A imputação de responsabilidade por erros honestamente cometidos afastaria profissionais competentes da administração de companhas}

De acordo com a United States District Court de Ohio, no julgamento do caso Granada Investments, Inc. v. DWG Corp.,

if management were liable for mere good faith errors in judgment, few capable individuals would be willing to incur the financial and emotional risk of serving as a director or officer ${ }^{309}$.

O mesmo entendimento foi demonstrado pela United States District Court

de Columbia no caso Washington Bancorporation v. Said. Para essa corte, imputar responsabilidade aos administradores por erros cometidos de boa-fé

${ }^{309}$ Granada Investments, Inc. v. DWG Corp., 823 F.Supp. 448 (1993). 
destruiria o sistema corporativo dos Estados Unidos, pois ninguém aceitaria os cargos de diretores ou conselheiros de companhias ${ }^{310}$.

No Brasil, o Colegiado da CVM também já reconheceu que administradores capacitados se afastariam de suas funções se pudessem ser pessoalmente responsabilizados por decisões negociais:

as companhias abertas perder[iam] competitividade para atrair administradores capacitados, em razão da possibilidade de responsabilização pessoal, a ser decidida com base em um conjunto de informações e sob situação diversa da que estarão submetidos quando tomarem suas decisões ${ }^{311}$.

Nesse sentido, como explica GOLDBERG, pessoas qualificadas não se aventurariam nos cargos de administração de companhias se a lei impusesse um padrão de diligência maior do que aquele imposto às pessoas ordinárias na performance de seus deveres ${ }^{312}$. Assim, "the rule allows corporate management to formulate policy and to make business decisions without the fear of personal liability"313.

\subsubsection{Administradores devem ser encorajados a tomar riscos}

Como se viu no item 2.3 desta monografia, há uma relação necessária entre risco, incerteza e lucro, de forma que este último não é alcançável em um cenário sem riscos e incertezas. E estes dois elementos existem justamente por não ser possível se saber o que acontecerá no futuro.

Se o futuro fosse por todos conhecido, de forma que todos os resultados de todas decisões fossem previamente sabidos, não haveria risco nem incerteza. Não haveria, portanto, lucro. O mercado se anteciparia e ajustaria seus elementos

\footnotetext{
${ }^{310}$ Nas palavras da corte: "To impose liability on directors for these good-faith business decisions, however, would effectively destroy the corporate system in this country, for no individuals would serve as officers and directors" Washington Bancorporation v. Said, 812 F.Supp. 1256 (1993).

${ }^{311}$ Processo Administrativo Sancionador CVM no 21/04, Rel. Pedro Oliva Marcilio de Sousa, j. em 15 mi. 2007.

312 GOLDBERG, Mindy K. How Much Information is Enough. Journal of Law and Commerce, vol. 7, p. 225.

313 Ibid., p. 226.
} 
ao estado ideal, de forma que todos os preços ficassem iguais aos seus custos respectivos.

No entanto, não podendo o futuro ser previsto, decisões tomadas podem gerar retornos ruins, independentemente do esforço de seu decisor. Como observa BLACK, “an investment in a company's shares can turn out badly for many reasons, of which bad management decisions are only one"314/315.

Ao investir em uma companhia, presume-se que os acionistas tenham grande tolerância à tomada de $\operatorname{riscos}^{316}$. Isso se explica, em primeiro lugar, pelo fato de que o acionista, obviamente, não é obrigado a investir em ações. Há inúmeros outros investimentos menos arriscados, que não estão sujeitos a decisões infelizes de administradores.

Nesse sentido, de acordo com a Corte de Apelações dos Estados Unidos, (...) shareholders to a very real degree voluntarily undertake the risk of bad business judgment. Investors need not buy stock, for investment markets offer an array of opportunities less vulnerable to mistakes in judgment by corporate officers. Nor need investors buy stock in particular corporations. In the exercise of what is genuinely a free choice, the quality of a firm's management is often decisive and information is available from professional advisors ${ }^{317}$.

Em segundo, BAINBRIDGE aponta que os acionistas podem eliminar grande parte dos riscos inerentes à atividade de sua companhia pela diversificação de seu portfólio. Um investimento arriscado representa menos chances de perda se inserido em um portfólio ao lado de investimentos mais

\footnotetext{
${ }^{314}$ BLACK, Bernard S. The Core Fiduciary Duties of Outside Directors. Asia Business Law Review, ${ }^{\circ}$ 3-16, jul. 2001. p. 15.

315 Vale citar também o seguinte trecho do autor: “(...) some risky decisions will work out wonderfully, while others will work out terribly. If the directors -- who are and ought to be modestly paid, lest high pay compromise their independence -- face even a small risk of personal liability for a bad outcome, they will be reluctant to take risks generally. They may make fewer bad risky decisions, but they will also make fewer good risky decisions. We may not get better decisions on average, just more cautious decisions" Ibid., p. 15.

316 "The risk of bad decisions, like the other sources of bad outcomes, is a risk that shareholders knowingly assume. Moreover, this is a risk that shareholders can reasonably assume because the directors' and shareholders' interests largely coincide" Ibid., p. 15.

317 Joy v. North, 692 F.2d 880 (1982).
} 


\section{seguros $^{318}$. Assim, "although investors are risk averse and therefore demand a}

risk premium when investing, that premium will only reflect certain risks"319/320.

Em terceiro, a responsabilidade pessoal dos acionistas por obrigações da companhia é limitada ao preço inicialmente investido ${ }^{321}$. Não é, então, o seu patrimônio pessoal que está em risco ${ }^{322}$.

318 AMAN bem ilustra esse raciocínio: "For example, suppose that a corporation can choose between two potential projects. Project A has a $90 \%$ chance of yielding $\$ 1000$, and therefore has an expected value of $\$ 900$. Project B has a $10 \%$ chance of yielding $\$ 9100$, and therefor has an expected value of $\$ 910$. A diversified shareholder would prefer that the corporation undertake Project B because it has a higher expected value. The fact that Project B also involves considerably more uncertainty for the particular firm making the investment is unimportant because diversified shareholders are not concerned about the level of diversifiable risk associated with particular firms" AMAN, Todd M. Cost-Benefit Analysis of the Business Judgment Rule: a Critique in Light of the Financial Meltdown. Albany Law Review. v. 74, 2010-2011. p. 13.

${ }^{319}$ BAINBRIDGE, Stephen M. The Business Judgment Rule as Abstention Doctrine. Vanderbilt Law Review. vol. 57, $\mathrm{n}^{\circ} 1$, p. 112.

${ }^{320}$ Ainda sobre a tolerância dos acionistas à tomada de riscos, vale trazer o exposto pela Corte de Chancelaria de Delaware, no julgamento do caso Gagliardi v. TriFoods Inter., Inc, 683 A.2d 1049 (1996): "Shareholders can diversify the risks of their corporate investments. Thus, it is in their economic interest for the corporation to accept in rank order all positive net present value investment projects available to the corporation, starting with the highest risk adjusted rate of return first. Shareholders don't want (or shouldn't rationally want) directors to be risk averse. Shareholders' investment interests, across the full range of their diversifiable equity investments, will be maximized if corporate directors and managers honestly assess risk and reward and accept for the corporation the highest risk adjusted returns available that are above the firm's cost of capital.

But directors will tend to deviate from this rational acceptance of corporate risk if in authorizing the corporation to undertake a risky investment, the directors must assume some degree of personal risk relating to ex post facto claims of derivative liability for any resulting corporate loss.

Corporate directors of public companies typically have a very small proportionate ownership interest in their corporations and little or no incentive compensation. Thus, they enjoy (as residual owners) only a very small proportion of any "upside" gains earned by the corporation on risky investment projects. If, however, corporate directors were to be found liable for a corporate loss from a risky project on the ground that the investment was too risky (foolishly risky! stupidly risky! egregiously risky! — you supply the adverb), their liability would be joint and several for the whole loss (with I suppose a right of contribution). Given the scale of operation of modern public corporations, this stupefying disjunction between risk and reward for corporate directors threatens undesirable effects. Given this disjunction, only a very small probability of director liability based on "negligence", "inattention", "waste", etc., could induce a board to avoid authorizing risky investment projects to any extent! Obviously, it is in the shareholders' economic interest to offer sufficient protection to directors from liability for negligence, etc., to allow directors to conclude that, as a practical matter, there is no risk that, if they act in good faith and meet minimal proceduralist standards of attention, they can face liability as a result of a business loss".

${ }^{321}$ No direito brasileiro, o artigo $1^{\circ}$ da Lei das S.A. versa o seguinte: "A companhia ou sociedade anônima terá o capital dividido em ações, e a responsabilidade dos sócios ou acionistas será limitada ao preço de emissão das ações subscritas ou adquiridas".

${ }^{322}$ Conforme BAINBRIDGE: "Because shareholders thus do not put their personal assets at jeopardy, other than the amount initially invested, they effectively externalize some portion of the business' total risk exposure to creditors" BAINBRIDGE, Stephen M. The Business Judgment Rule as Abstention Doctrine. Vanderbilt Law Review. vol. 57, nº 1, p. 111. 
Um acionista racional, assim, deseja que seus administradores tomem certos riscos para que seus retornos, na forma de dividendos, sejam maiores. Devido à diversificação de riscos, os reflexos ruins dessa atitude não serão tão gravosos. Em contrapartida, um administrador racional, que normalmente tem grande parte de seu capital humano investido em uma companhia, bem como uma reputação profissional a zelar, tende a adotar todos os cuidados para que a tomada de riscos não seja exagerada e não ruine os negócios da sociedade ${ }^{323}$.

\section{É o que observa GORDON:}

(...) managers and shareholders start with different attitudes toward firm-specific risk. Managers generally make large firm-specific human capital investments in their firms and thus are risk-averse; shareholders in public firms generally are reasonably welldiversified (or at least have the opportunity to be) and thus are generally risk-neutral. Managers therefore might well choose projects with lower expected returns but less variance than shareholders otherwise would prefer $^{324}$.

Há, portanto, pesos e contrapesos à tomada de riscos impostos pela relação triangular existente entre administrador, acionista e companhia, não sendo necessária qualquer medida por parte do Estado para realizar qualquer tipo de controle a esse respeito.

Não obstante, também a sociedade civil tem interesse na tomada de riscos e na proteção patrimonial dos administradores por suas decisões à frente de uma companhia. O desenvolvimento de negócios é de extrema importância para a economia de um país. Assim já expôs a Suprema Corte de Minnesota:

(...) protecting directors' reasonable risks is considered positive for the economy overall, as those risks allow businesses to attract risk-averse managers, adapt to changing markets, and capitalize on emerging trends ${ }^{325}$.

Tendo isso em vista, nas palavras de BLOCK et al, "the business judgment rule recognizes that business decisions frequently entail risk and

\footnotetext{
323 Ibid., p. 113.

${ }^{324}$ GORDON, Jeffrey N. What Enron Means for the Management and Control of the Modern Business Corporation: Some Initial Reflections. The University of Chicago Law Review. v. 69, 2002. p. 1245.

325 Janssen v. Best \& Flanagan, 662 N.W.2d 876 (2003).
} 
uncertainty" e, assim, "encourages directors to engage in ventures which have potential for great profit but which may entail some risk"326.

\subsubsection{Juízes não são administradores}

Juízes são responsáveis por aplicar a lei a um caso concreto. Como observa CORREAA LIMA, “ao juiz incumbe a árdua e difícil tarefa de julgar os casos concretos com os olhos voltados para os objetivos maiores da lei aplicada", e, assim, "[sintoniza] as dissonâncias que encontrar entre os conjuntos das normas substantivo-materiais e das regras adjetivo-processuais" ${ }^{\text {"327. }}$

Os juízes, então, tendem a ser profundos conhecedores do mundo jurídico. A todo tempo devem estudar as leis e suas interpretações, de modo a sempre aplicá-las da melhor forma possível aos casos que tiver que julgar.

Mas, infelizmente, não se pode dizer que juízes tendem a ser grandes conhecedores das outras áreas do conhecimento que não o Direito. Afinal, a capacidade intelectual do ser humano é naturalmente limitada. Um juiz não costuma ser um grande conhecedor de medicina, engenharia ou arquitetura, por exemplo. Qualquer um estranharia se um magistrado opinasse ou interviesse na atividade dos profissionais dessas áreas.

E o mesmo se aplica à atividade de administração de sociedades empresariais. Tão inadequado quanto um juiz oferecer consultas médicas e erguer prédios é ele definir o que é melhor para os negócios de uma sociedade empresária sem nem mesmo dela fazer parte.

Assim entende BAINBRIDGE:

Business decisions are frequently complex and made under conditions of uncertainty. Accordingly, bounded rationality and information asymmetries counsel judicial abstention from reviewing board decisions. Judges likely have less general business

\footnotetext{
${ }^{326}$ BLOCK, Dennis J.; BARTON, Nancy E.; RADIN, Stephen A. The Business Judgment Rule: Fiduciary Duties of Corporate Directors. 6 ed. vol. 1. New York: Aspen Publishers, 2009. p. 30-31. 327 CORRÊA LIMA, Osmar Brina. Responsabilidade Civil dos Administradores de Sociedade Anônima. Rio de Janeiro: Aide Ed., 1989. p. 154.
} 
expertise than directors. They also have less information about the specifics of the particular firm in question ${ }^{328}$.

Decisões negociais, normalmente, em razão da velocidade do mercado, são tomadas rapidamente, com base na quantidade de informações que se foi possível reunir. Esperar para acumular mais informações, em muitos casos, é mais custoso do que tomar a decisão de maneira menos informada.

Dessa forma, ao analisar e julgar decisões depois que elas foram tomadas, com o tempo e a informação que se desejar acumular, os juízes se encontram em uma situação muito mais confortável do que aquela dos administradores quando da tomada de decisões. Dessa maneira, magistrados e acionistas podem apontar quanto os administradores poderiam saber ao tempo da decisão, mas não sabiam; ou se a decisão realmente deveria ter sido tomada rapidamente ${ }^{329}$.

Como sugere BLACK, "a decision that was reasonable when made may seem unreasonable in hindsight",330.

Nesse sentido, também é importante ressaltar que, como se notou ao longo da leitura do Capítulo 2 desta monografia, a tomada de decisão de administradores está sujeita a diversos fatores inerentes a um mercado competitivo. A decisão que não alcançar seus objetivos econômicos receberá as correspondentes rejeições do próprio mercado, seja com a desconstituição do administrador, seja com uma mancha em sua reputação profissional, seja com reflexos na performance da companhia e nos investimentos nela realizados ${ }^{331}$.

\footnotetext{
${ }^{328}$ BAINBRIDGE, Stephen M. The Business Judgment Rule as Abstention Doctrine. Vanderbilt Law Review. vol. 57, nº 1, p. 119.

${ }^{329}$ Nesse sentido, de acordo com BLACK: “(...) judges are usually not businesspeople. They are bad at second-guessing decisions that turned out poorly, and deciding whether they were poor decisions when made. Business decisions are often made quickly, based on highly incomplete information. Yet, the delay to gather better information may be as costly as the mistakes from proceeding without the information. With the benefit of hindsight, a complaining shareholder can point out how much the directors could have known but did not know when deciding, or how rushed their decision was" BLACK, Bernard S. The Core Fiduciary Duties of Outside Directors. Asia Business Law Review, no 3-16, jul. 2001. p. 15. ${ }^{330}$ Ibid., p. 15.

${ }^{331}$ Como colocado pela Corte de Apelações dos Estados Unidos, "shareholders can and do select among investments partly on the basis of management (...)" Joy v. North, 692 F.2d 880 (1982).
} 
O mesmo, naturalmente (e felizmente), não ocorre com as decisões judiciais. Decisões tomadas por juízes - quando agindo como juízes - não estão sujeitas a nenhum tipo de crivo advindo do mercado. Os magistrados que proferirem decisões ineficientes não serão demitidos ou punidos pelas leis do mercado.

Levando isso em conta, os incentivos para bem calcular e estudar as decisões negociais são muito maiores para administradores do que para juízes. Por isso, o interesse dos acionistas é que as decisões econômicas relacionadas aos negócios de suas companhias sejam tomadas por aqueles, e não por estes.

Nessa direção, vale citar mais um trecho de BAINBRIDGE:

Corporate directors operate within a pervasive web of accountability mechanisms. A very important set of constraints are provided by competition in a number of markets. The capital and product markets, the internal and external employment markets, and the market for corporate control all constrain shirking by directors and managers. Granted, only the most naive would assume that these markets perfectly constrain director decision making. It would be equally naive, however, to ignore the lack of comparable market constraints on judicial decision making. Market forces work an imperfect Darwinian selection on corporate decision makers, but no such forces constrain erring judges. As such, rational shareholders will prefer the risk of director error to that of judicial error. Hence, shareholders will want judges to abstain from reviewing board decisions ${ }^{332}$.

\subsubsection{Companhias são geridas por administradores, e não por acionistas}

Como exposto no Capítulo 1 deste trabalho, as companhias são geridas por uma diretoria e um conselho de administração. Conforme versa o caput do artigo 138 da Lei das S.A., "a administração da companhia competirá, conforme dispuser o estatuto, ao conselho de administração e à diretoria, ou somente à diretoria".

A business judgment rule reconhece, então, que essa função é exclusiva dos administradores, sendo eles quem decidem os rumos que a sociedade tomará. Ceder aos acionistas um poder excessivo de interferência em suas decisões, seja

\footnotetext{
332 BAINBRIDGE, Stephen M. The Business Judgment Rule as Abstention Doctrine. Vanderbilt Law Review. vol. 57, n⿳ 1, p. 122.
} 
por meio da concessão de amplos direitos, seja por meio dos tribunais, faria com que a efetiva administração das companhias fosse por eles exercida.

O resultado de tamanha supervisão e interferência dos acionistas nas decisões de administradores seria a transferência da tomada de decisão destes para aqueles. E o problema disso é que nem sempre os interesses de todos os acionistas convergem para um mesmo ponto sobre todos os assuntos da companhia.

Assim sendo, permitir tal interferência teria como resultado final a transferência do poder de administração a um ou poucos acionistas cujos interesses se diferem dos interesses dos demais. É o que explicam DOOLEY e VEASEY:

The power to hold to account is the power to interfere and, ultimately, the power to decide. If stockholders are given too easy access to courts, the effect is to transfer decisionmaking power from the board to the stockholders or, more realistically, to one or a few stockholders whose interests may not coincide with those of the larger body of stockholders ${ }^{333}$.

Dessa maneira, um único acionista poderia, por meio de uma ação judicial e com base nas suas próprias percepções a respeito de certo negócio, interferir nas decisões da companhia. A centralização do poder de decisão na administração da companhia, cujos membros são eleitos direta ou indiretamente $^{334}$ pela assembleia geral, se perderia e a continuação de seus negócios se tornaria inviável.

Nesse sentido, SILVA diz que,

se aos acionistas é concedido o direito de demandar revisão de decisões dos administradores, o resultado pode ser a transferência de autoridade do conselho de administração para qualquer acionista que deseje reclamar ${ }^{335}$.

333 DOOLEY, Michael P.; VEASEY, E. Norman. The Role of the Board in Derivative Litigation: Delaware Law and the Current ALI Proposals Compared. The Business Lawyer. v. 44, nº 2, fev. 1989. p. 522.

${ }^{334}$ Indiretamente porque, nas companhias em que houver conselho de administração, será ele quem elegerá a diretoria.

335 SILVA, Alexandre Couto. Responsabilidade dos Administradores de S/A: Business Judgment Rule. Rio de Janeiro: Elsevier, 2007. p. 192. 
Sob esse aspecto, então, a business judgment rule acaba funcionando como uma proteção dos acionistas contra eles mesmos. Cite-se, nessa direção, outro trecho de DOOLEY e VEASEY:

By limiting judicial review of board decisions, the business judgment rule preserves the statutory scheme of centralizing authority in the board of directors. In doing so, it also preserves the value of centralized decisionmaking for the stockholders and protects them against unwarranted interference in that process by one of their number. Although it is customary to think of the business judgment rule as protecting directors from stockholders, it ultimately serves the more important function of protecting stockholders from themselves ${ }^{336}$.

\subsubsection{Acionistas podem desconstituir e substituir os administradores}

É poder exclusivo da assembleia geral de acionistas eleger os administradores da sociedade anônima ${ }^{337}$. Tais administradores, nesse sentido, são destituíveis a qualquer momento, mesmo que seus mandatos não tenham se encerrado $^{338}$. Nas sociedades em que houver conselho de administração, cujos membros são eleitos pelos acionistas, caberá a este órgão a eleição e destituição dos membros da diretoria (o que não deixa de ser uma decisão negocial, protegida pela business judgment rule $\left.{ }^{339}\right)$.

Nesse sentido, BLOCK et al afirmam que "courts have stated that the business judgment rule recognizes that unhappy shareholders can always vote the directors out of office" 340 .

Portanto, se estiverem insatisfeitos com o resultado da administração, os acionistas podem destituir os administradores de seus cargos, o que é um grande

\footnotetext{
${ }^{336}$ DOOLEY, Michael P.; VEASEY, E. Norman. The Role of the Board in Derivative Litigation: Delaware Law and the Current ALI Proposals Compared. The Business Lawyer. v. 44, $\mathrm{n}^{\circ}$ 2, fev. 1989. p. 522.

${ }^{337}$ De acordo com o artigo 132, III, da Lei das S.A., compete à assembleia geral ordinária "eleger os administradores e os membros do conselho fiscal, quando for o caso".

${ }^{338}$ Nesse sentido versam os artigos 140 e 143 da Lei das S.A., a seguir, respectivamente: "O conselho de administração será composto por, no mínimo, 3 (três) membros, eleitos pela assembleia-geral e por ela destituíveis a qualquer tempo (...)”; "A Diretoria será composta por 2 (dois) ou mais diretores, eleitos e destituíveis a qualquer tempo pelo conselho de administração, ou, se inexistente, pela assembleia-geral (...)".

${ }^{339}$ Vai nesse sentido o julgamento do caso In Re Walt Disney Co. Derivative Litigation, 825 A.2d 275 (2003).

340 BLOCK, Dennis J.; BARTON, Nancy E.; RADIN, Stephen A. The Business Judgment Rule: Fiduciary Duties of Corporate Directors. 6 ed. vol. 1. New York: Aspen Publishers, 2009. p. 40.
} 
incentivo para que estes bem exerçam suas funções. A punição pela tomada de decisões insatisfatórias, assim, deve ter como limite a perda do cargo na administração, e não uma reparação civil imposta por um tribunal.

E, como já expôs a CVM, a possibilidade de destituição de seu cargo é uma grande influência aos administradores para que realizem uma boa gestão:

(...) o interesse do administrador em continuar em seu cargo gera importante incentivo para o alinhamento de interesses entre ele e a companhia, uma vez que a melhor maneira de convencer os acionistas a mantê-lo no cargo consiste, justamente, em realizar uma boa gestão ${ }^{341}$.

${ }^{341}$ Processo Administrativo Sancionador CVM no 09/06, Rel. Ana Dolores Moura Carneiro de Novaes, j. em 5 mar. 2013. 


\section{CAPÍTULO 5 - A BUSINESS JUDGMENT RULE NO DIREITO BRASILEIRO}

Após o estudo da business judgment rule nos moldes em que foi idealizada pela jurisprudência norte-americana, o presente Capítulo terá como objeto a análise da recepção da regra no direito brasileiro, bem como da atuação da CVM e do Poder Judiciário nos casos em que a conduta de um administrador de companhias está em exame.

Assim, em primeiro lugar, será explicada a forma como a maior parte da doutrina brasileira enxerga a business judgment rule na Lei das S.A. Em seguida, uma nova percepção sobre esse aspecto será apresentada.

Depois, serão analisados os entendimentos da CVM a respeito da regra em julgamentos ocorridos entre os anos de 2000 e 2014.

Por fim, no que se refere ao Poder Judiciário, dois (preocupantes) casos julgados serão estudados, demonstrando-se uma grave despreparação dos magistrados brasileiros para o julgamento de questões empresariais.

\subsection{A recepção da regra pela Lei das S.A.}

\subsubsection{O entendimento majoritário: a business judgment rule e ० $\S 6^{\circ}$ do artigo 159}

Apesar de ser o assunto pouco debatido, é praticamente unânime, com pouquíssimas divergências, o entendimento de que a business judgment rule encontra-se recepcionada pelo direito brasileiro no $\S 6^{\circ}$ do artigo 159 da Lei das S.A., analisado no item 3.1.4 deste trabalho, que versa que "o juiz poderá reconhecer a exclusão da responsabilidade do administrador, se convencido de que este agiu de boa-fé e visando ao interesse da companhia".

Para aqueles que defendem esse raciocínio, todos os elementos da regra norte-americana estariam abarcados pelo dispositivo. É o que entende CORRÊA LIMA: 
A história da formação da atual lei de sociedades por ações brasileira leva-nos a crer que a referida transposição de seculares princípios e teorias jurídicas para o $\S 6^{\circ}$ do art. 159 da Lei n. 6.404/76 foi mais inconsciente que consciente.

Num plano consciente, o legislador brasileiro parece ter se limitado a transpor, para a legislação pátria, a famosa business judgment rule, inferida através do processo lógicoindutivo da jurisprudência norte-americana e expressa em alguns Códigos, como o Model Business Corporation $\mathrm{Act}^{342}$.

EIZIRIK, no mesmo sentido, afirma:

$\mathrm{O}$ artigo $159, \S 6^{\circ}$, inequivocamente consagrou a business judgement rule ao proteger o administrador quando se constatar que agiu de boa-fé e visando a atingir os melhores interesses da companhia. A regra, tal como interpretada, permite ao aplicador da lei, seja na esfera judicial, seja na esfera administrativa, dar maior concretude ao standard do dever de diligência, uma vez que possibilita a sua aferição diante de casos concretos $^{343}$.

\section{BLOK também entende dessa forma:}

No Brasil, a Lei das Sociedades por Ações consagrou a Business judgment rule em seu art. $159, \S 6^{\circ}$, conferindo ao julgador a análise do caso particular com a valoração concreta do procedimento do administrador na esfera psicológica para a aferição subjetiva $^{344 / 345}$.

Contudo, como se mostrará a seguir, não parece ser essa a melhor conclusão a respeito da recepção da business judgment rule no direito brasileiro.

${ }^{342}$ CORRÊA LIMA, Osmar Brina. Responsabilidade Civil dos Administradores de Sociedade Anônima. Rio de Janeiro: Aide Ed., 1989. p. 126. O autor expressou o mesmo entendimento em CORRÊA LIMA, Osmar Brina. Regra de Julgamento de Negócios ("Business Judgment Rule”). In: SILVA, Alexandre Couto (Org.). Direito Societário: estudos sobre a Lei de Sociedades por Ações. São Paulo: Saraiva, 2013. p. 156.

${ }^{343}$ EIZIRIK, Nelson. A Lei das S/A Comentada. vol. II. São Paulo: Quartier Latin, 2011. p. 416.

${ }^{344}$ BLOK, Marcella. Business Judgment Rule: a responsabilidade dos administradores das sociedades anônimas. Revista de Direito Bancário e do Mercado de Capitais. vol. 46. out. 2009. p 146-147.

${ }^{345}$ No mesmo sentido: "A Lei de Sociedades por Ações Brasileira consagrou a business judgment rule em seu art. 159, $\S 6^{\circ}$, conferindo ao julgador a análise do caso particular com valoração concreta do procedimento do administrador da esfera psicológica para apreciação subjetiva" SILVA, Alexandre Couto. Responsabilidade dos Administradores de S/A: Business Judgment Rule. Rio de Janeiro: Elsevier, 2007. p. 249; "No Brasil, a Regra do Julgamento do Negócio encontra previsão no art. 159, § 6º da Lei n. 6.404/76, segundo o qual 'o juiz poderá reconhecer a exclusão da responsabilidade do administrador, se convencido de que este agiu de boa-fé e visando ao interesse da companhia" NASCIMENTO, João Pedro Barroso do. Regra do Julgamento do Negócio (Business Judgment Rule). In: SILVA, Alexandre Couto (Org.). Direito Societário: estudos sobre a Lei de Sociedades por Ações. São Paulo: Saraiva, 2013. p. 175; CUNHA, Rodrigo Ferraz Pimenta da. Estrutura de Interesses nas Sociedades Anônimas: hierarquia e conflitos. São Paulo: Quartier Latin, 2007. p. 225 e 226; “A LSA brasileira, publicada em 17.12.1976, em grande parte de seu conteúdo, possui clara inspiração no MBCA norte-americano. Tendo em vista a densidade daquele diploma (especialmente na época de elaboração da redação da LSA), natural a inserção de dispositivos e premissas ali dispostos. Daí porque se justificam os parâmetros traçados para delimitar os deveres gerais (de cuidado e lealdade) do administrador, bem como a regra do $\S 6 .^{\circ}$ do art. 159, associada à business judgment rule" RIBEIRO, Júlio Cesar de Lima. A transposição da business judgment rule para o regime da responsabilidade civil de administradores em Portugal e no Brasil. Revista dos Tribunais. v. 937, nov. 2013, p. 391. 
Em primeiro lugar, porque o $\S 6^{\circ}$ do artigo 159 não abrange todos os elementos da regra. O dispositivo da Lei das S.A. determina que a responsabilidade do administrador poderá ser excluída se ele tiver agido apenas (i) de boa-fé; e (ii) no interesse da companhia. Mas a business judgment rule é mais ampla do que isso.

Como se viu no capítulo anterior desta monografia, são quatro os elementos dessa regra: (i) ocorrência de uma decisão; (ii) desinteresse e independência; (iii) diligência; e (iv) boa-fé.

À primeira vista, percebe-se que o artigo $159, \S 6^{\circ}$, da Lei das S.A. e a business judgment rule possuem em comum o elemento boa-fé. Restam, porém, outros três elementos da business judgment rule que, para que se possa afirmar que o referido dispositivo tenha recepcionado a regra norte-americana, devem ser compatíveis com o outro elemento da norma brasileira: agir no interesse da companhia.

Para se compreender o que seria agir no interesse da companhia no direito brasileiro, deve-se recorrer ao que dispõe o caput do artigo 154 da Lei das S.A. De acordo com o dispositivo, "o administrador deve exercer as atribuições que a lei e o estatuto lhe conferem para lograr os fins e no interesse da companhia".

Nesse sentido, ABREU bem resume o conceito de interesse da companhia, também chamado de interesse social:

\begin{abstract}
O interesse social há de ser interesse comum aos sócios (enquanto sócios): Numa mesma sociedade, uns sócios (enquanto tais) terão normalmente interesses divergentes dos outros sócios - v.g., quanto à participação nos órgãos sociais e à manutenção ou aumento das respectivas posições (e correspondente poder) na sociedade. $\mathrm{O}$ interesse social não é feito destas divergências de interesses. É feito, sim, da comunidade de interesses dos sócios. Mas não de qualquer comunidade. Ela só é qualificável como interesse social quando se ligue à causa comum do acto constituinte da sociedade - que é, em regra (sabemos já), o escopo lucrativo (todo e qualquer sócio pretende lucrar participando na sociedade); qualquer outro interesse coletivo ou comum de que sejam titulares os sócios já não merece tal qualificação ${ }^{346}$.
\end{abstract}

\footnotetext{
346 ABREU, Jorge Manuel Coutinho de. Curso de Direito Comercial, Sociedades. Coimbra: Almedina, 2003. p. 291 e 292. apud. CAMPOS, Luiz Antonio de Sampaio. Op. cit., p. 1113-1114. A esse respeito, vale trazer ensinamento de FRANÇA sobre o que configura o interesse da companhia: "A sociedade, como ensina Ascarelli, constitui uma comunhão voluntária de interesses, como tal distinta quer da
} 
Portanto, conforme EIZIRIK, o administrador deve atuar visando a "alcançar o desenvolvimento do objeto social da forma mais lucrativa possível"347. E é justamente esse o limite da discricionariedade concedida aos administradores. Sobre isso, assim aponta CAMPOS:

O interesse social e o cumprimento do objeto social limitam a liberdade e a discricionariedade do administrador, à medida que todos os atos, decisões e escolhas do administrador devem estar voltados primordialmente para o atendimento do objeto e do interesse social, embora deva ainda observar a função social da empresa e as exigências do bem público ${ }^{348}$.

Isso se dá porque "os poderes de administração são conferidos exclusivamente para que a companhia possa desenvolver as atividades compreendidas no objeto social e no interesse social" 349 .

Assim sendo, desvirtuam dessa função e vão contra o interesse social os atos de administradores que agirem de forma interessada e/ou não independente. Isso porque, nesses casos, o objetivo maior do administrador não será a consecução do objeto social e a obtenção de lucro para a companhia, mas, sim, o benefício próprio ou de terceiro.

Nesse sentido, conforme SILVA,

\footnotetext{
comunhão acidental (avaria comum), quer da comunhão necessária (condomínio forçado). Já pelo fato de ser uma comunhão voluntária de interesses, a sociedade constitui uma comunhão de escopo, sendo justamente através da constituição contratual de uma comunhão de escopo que se constitui a comunhão de interesses. Ora, a comunhão de escopo, lembra Ascarelli, se coordena com um interesse comum a todos os participantes, de maneira que nos confrontos de cada um dos participantes pode-se distinguir um interesse extra-social e um interesse que, embora próprio de cada um, é comum a todos. É da natureza do contrato de sociedade, como contrato plurilateral, outrossim, não obstante essa comunhão de escopo, a possibilidade de conflito entre o interesse individual dos sócios e o interesse comum, dada a eventual concorrência entre os sócios, mesmo durante a vida da sociedade, para obter maiores vantagens econômicas ou assumir o controle societário. Ora, qual é esse interesse comum que une os sócios, da fundação da sociedade à sua dissolução, no dizer de Mignoli? Trata-se do interesse à realização do escopo social, ou, se se preferir, de qualquer interesse que se insira no esquema causal do contrato de sociedade. Abrange, portanto, tanto o denominado escopo-meio, que é o exercício da empresa, considerada como objeto da sociedade (art. $2^{\circ}$ da Lei 6.404), como o escopo-fim, de produção e de distribuição de lucros entre os sócios, sob a forma de dividendos" FRANÇA, Erasmo Valladão Azevedo e Novaes. Conflito de Interesses nas Assembleias de S.A. São Paulo: Malheiros, 1993. p. 59-60.

${ }^{347}$ EIZIRIK, Nelson. A Lei das S/A Comentada. vol. II. São Paulo: Quartier Latin, 2011. p. 359. Lembra o autor, ainda, que "tais objetivos, embora prevalecentes, devem ser perseguidos ao menor custo possível para a comunidade" Ibid. p. 359.

${ }^{348}$ CAMPOS, Luiz Antonio de Sampaio. Deveres e Responsabilidades. In: LAMY FILHO, Alfredo; PEDREIRA, José Luiz Bulhões (Org.). Direito das Companhias. Rio de Janeiro: Forense, 2009. p. 11111112.

${ }^{349}$ Ibid., p. 1122.
} 
o administrador será considerado interessado quando receber benefícios financeiros da transação que não são divididos com os acionistas, ou em que a decisão terá impacto financeiro para o administrador, mas não para a companhia ou para os acionistas ${ }^{350}$.

Ainda segundo o autor,

o administrador não será independente quando for dominado ou controlado por credor ou pessoa, jurídica ou natural, interessada na conduta ou na transação que possa influenciar a capacidade de discricionariedade ${ }^{351}$.

Pode-se concluir, diante disso, que o administrador que agir de forma desinteressada e independente agirá, consequentemente, no interesse da companhia. Por isso, o elemento desinteresse e independência da business judgment rule se mostra perfeitamente compatível com agir no interesse da companhia, conforme previsto no artigo $159, \S 6^{\circ}$, da Lei das S.A.

Mas não é o que ocorre com os elementos ocorrência de decisão negocial e diligência da regra norte-americana.

Quanto ao primeiro, parece evidente o fato de que não há qualquer menção, na norma da Lei das S.A., da necessidade de ter o administrador praticado uma decisão negocial para que o juiz possa excluir sua responsabilidade.

E, como explicam BLOCK et al, "as a threshold matter, the business judgment rule requires a business judgment" 352 . Assim, "only director action is protected by the business judgment rule; inaction is not protected unless it is the result of a conscious decision not to act ${ }^{\prime 353}$.

Quanto ao segundo, como já visto no Capítulo 4 do presente trabalho e entendido no âmbito do julgamento do caso Cede \& Co. v. Technicolor, Inc.,

\footnotetext{
${ }^{350}$ SILVA, Alexandre Couto. Responsabilidade dos Administradores de S/A: Business Judgment Rule. Rio de Janeiro: Elsevier, 2007. p. 195.

${ }^{351}$ Ibid. p. 196.

${ }^{352}$ BLOCK, Dennis J.; BARTON, Nancy E.; RADIN, Stephen A. The Business Judgment Rule: Fiduciary Duties of Corporate Directors. 6 ed. vol. 1. New York: Aspen Publishers, 2009. p. 87.

353 Ibid., p. 87.
} 
the duty of the directors of a company to act on an informed basis, as that term has been defined by this Court numerous times, forms the duty of care element of the business judgment rule ${ }^{354}$.

Em complemento, BRADLEY e SCHIPANI afirmam que "another formulation of the duty of care is that degree of care required to avoid gross negligence" ${ }^{355}$. A doutrina nacional, ressalte-se, vai no mesmo sentido. Para PARENTE,

O dever de diligência, em sentido lato, pode ser entendido sob dois aspectos:

a) o subjetivo, que indica a pretensão do sujeito para cumprir, com cuidado, atenção e zelo, determinada obrigação a que está submetido, independentemente do resultado alcançado; e

b) o objetivo, segundo o qual a diligência deve ter um referencial pragmático, uma conduta determinada ligada a uma atividade concreta ou a um standard comportamental ${ }^{356}$.

A doutrina, ainda, divide o mencionado dever em cinco outros aspectos dele decorrentes, como se viu no Capítulo 1: (i) o dever de se informar; (ii) o dever de se qualificar; (iii) o dever de vigiar; (iv) o dever de investigar; e (v) o dever de intervir.

O elemento diligência da business judgment rule, então, é compatível com o dever de diligência previsto pelo artigo 153 da Lei das S.A. Cumpre, agora, verificar se o legislador pátrio teria abarcado tal dever como elemento do $\S 6^{\circ}$ do artigo 159.

Pela leitura dessa norma, nota-se que o administrador não precisa estar isento de culpa stricto sensu para que o juiz possa excluir a sua responsabilidade. Exige-se, vale repetir, que ele tenha agido de boa-fé e no interesse da companhia.

Ora, o elemento boa-fé afasta a possibilidade de exclusão da responsabilidade do administrador que tiver agido de má-fé. O elemento agir no interesse da companhia, por sua vez, causa o mesmo efeito àqueles atos que

\footnotetext{
${ }^{354}$ Cede \& Co. v. Technicolor, Inc., 634 A.2d 345, 367 (Del. 1993), modified on other grounds, 636 A.2d 956 (Del. 1994).

355 BRADLEY, Michael; SCHIPANI, Cindy A. The Relevance of the Duty of Care Standard in Corporate Governance. Iowa Law Review 75, n. 1, p. 18, 1989-1990.

356 PARENTE, Flávia. O Dever de Diligência dos Administradores de Sociedades Anônimas. Rio de Janeiro: Renovar, 2005. p. 38
} 
perquirirem outros interesses que não o da sociedade ou extrapolarem a discricionariedade a ele conferida.

Atos única e estritamente culposos, assim, parecem não estar abarcados pelo $§ 6^{\circ}$ do artigo 159 da Lei das S.A. e, dessa forma, não podem ser tomados como base para a exclusão da responsabilidade dos administradores pelo juiz. Mas também não são um impeditivo para tanto.

Em outras palavras, o julgador está autorizado pela lei a excluir a responsabilidade de um administrador por atos indiligentes caso ele tenha agido de boa-fé e no interesse da companhia.

Isso se dá porque, como entende ADAMEK, a atuação no interesse da companhia não se confunde com a atuação diligente dos administradores: "a causa de justificação tem aplicação somente se o juiz se convencer de que o administrador agiu de boa-fé e visando o interesse da companhia. Atos dolosos ou negligentes, assim, parecem escapar do alcance da regra" ${ }^{\text {357. }}$.

ROCHA também entende assim. Para o autor, a norma do artigo 159, §6 , reflete uma tolerância a atos negligentes cometidos por administradores sem máfé:

(...) naturalmente, não se considerariam os casos de dolo (art. 158, I), onde boa-fé não se admite, e sim os de algumas hipóteses de culpa, ou onde a negligência pequena pode conviver com a boa intenção e a falta de malícia, assim como eventos acaso ligados a excesso de poder (com violação do estatuto) ${ }^{358}$.

Cite-se também, ainda nesse sentido, o entendimento de Borba, ao comentar o que o dispositivo deixou de prever:

Restariam, então, as ocorrências de imprudência ou imperícia e de infração à lei e ao estatuto, nas quais, em certas circunstâncias, poder-se-ia divisar uma atuação do administrador que, conquanto contrária aos padrões normais, tenha se imposto como uma tentativa de salvar a sociedade ou os seus interesses superiores ${ }^{359}$.

\footnotetext{
357 ADAMEK, Marcelo Vieira von. Responsabilidade Civil dos Administradores de S/A e as ações correlatas. São Paulo: Saraiva, 2009. p. 287.

${ }^{358}$ ROCHA, João Luiz Coelho da. Administradores, conselheiros e prepostos das sociedades. Rio de Janeiro: Lumen Juris, 2005, p. 88.

${ }^{359}$ BORBA, José Edwaldo Tavares. Direito societário. $8^{\text {a }}$ ed. Rio de Janeiro: Renovar, 2003. p. 425.
} 
Portanto, não há outra conclusão possível a não ser a de que o juiz poderá excluir a responsabilidade do administrador que, agindo de boa-fé e no interesse da companhia, tenha faltado com o dever de diligência.

Além disso, como será melhor analisado mais adiante, para que se chegue até o ponto de o juiz poder excluir a responsabilidade do administrador, é necessário que esta já tenha sido reconhecida em algum momento. Dessa forma, se o dispositivo se aplica às hipóteses em que o administrador tiver agido de boafé e no interesse da companhia, a única possibilidade de responsabilização não prevista é aquela baseada em um ato estritamente culposo.

Isso porque, se a sua atuação tiver se dado de boa-fé, sem culpa stricto sensu e no interesse da companhia, não se falaria em responsabilidade civil.

Esse entendimento, contudo, não é unânime. Para CARVALHOSA,

A faculdade de julgamento por eqüidade, que se estabelece no $\S 6^{\circ}$, conjugada com o art. 127 da lei processual, tem como pressupostos a boa-fé do administrador e a convicção de que ele agiu no interesse da companhia. O primeiro exclui evidentemente o dolo e o segundo, a negligência e a imprudência, já que, nestes casos, impossível seria pensar-se em conduta visando ao interesse da companhia ${ }^{360}$.

Data venia, é perfeitamente possível que o administrador, de boa-fé e visando ao melhor interesse da companhia, aja de forma culposa e, por isso, cause prejuízos à companhia. Atuar no interesse da companhia não significa necessariamente atuar com a diligência que se espera do administrador de sociedade anônima.

Tome-se como exemplo a hipótese em que o diretor de uma sociedade anônima celebra contrato com terceiros buscando lucros para a sua companhia, mas sem ter se informado a respeito de importantes cláusulas, causando, com isso, prejuízos a ela e a seus acionistas. Ou o caso em que o conselheiro deixa de

${ }^{360}$ CARVAlHOSA, Modesto. Comentários à Lei de Sociedades Anônimas. $4^{\mathrm{a}}$ ed. vol. 2. São Paulo: Saraiva, 2009. p. 405. Grifo nosso. 
vigiar a atuação de diretores que, de má-fé, ocultam informações do balanço da companhia.

Em tais hipóteses, os administradores não agem de má-fé (estando de boafé, portanto) e nem visando a interesses alheios aos da sociedade. Há, sim, uma falta de diligência no exercício de suas funções causada por uma atuação negligente.

Mas não é só por causa da não previsão dos elementos ocorrência de decisão negocial e diligência que o dispositivo em tela não recepcionou a business judgment rule ${ }^{361}$.

Como já adiantado, ao dispor que o juiz poderá excluir a responsabilidade do administrador, o $\$ 6^{\circ}$ do artigo 159 pressupõe uma responsabilidade já existente (pois que não se exclui algo que não existe). O administrador, então, já seria responsável por seu ato, mas, se tiver agido de boa-fé e no interesse da companhia, poderá ter sua responsabilidade excluída pelo juiz.

Não é esse o escopo da business judgment rule. Por essa regra, o administrador não é, em momento algum, considerado responsável por seus atos. Pelo contrário: ele é protegido por uma presunção - relativa - de que agiu bem informado, de boa-fé e no interesse da companhia ${ }^{362}$. Deverá o juiz, se concluir que a conduta do administrador não preencheu esses requisitos, afastar tal presunção.

Assim, pela regra norte-americana, não tem o juiz a discricionariedade de decidir se o administrador será ou não responsabilizado. Tendo a sua conduta preenchido os requisitos acima citados, não há que se falar em responsabilidade.

\footnotetext{
${ }^{361}$ Apesar de defender que o artigo $159, \S 6^{\circ}$, tenha recepcionado a regra, LUCENA admite que tal norma não abarcou todos os seus requisitos: "o direito posto brasileiro (...) também veio de adotar, embora sem menção de todos os requisitos que a compõe, a business judgment rule, qual se vê do artigo $159, \S 6^{\circ}$, da atual lei acionária" LUCENA, José Waldecy. Das sociedades anônimas: comentários à lei (arts. 121 a 188). vol. 2. Rio de Janeiro: Renovar, 2009. p. 558 (grifo nosso).

${ }^{362}$ Conforme se decidiu no caso Aronson v. Lewis 473 A.2d 805 (1984), "it is a presumption that in making a business decision the directors of a corporation acted on an informed basis, in good faith and in the honest belief that the action taken was in the best interests of the company".
} 
E não é isso o que ocorre com o artigo $159, \S 6^{\circ}$, da Lei das S.A., como explica ADAMEK:

Há quem veja, no caso, a aplicação da business judgment rule, mas, a nosso ver, aqui a situação é outra: o juiz já avançou até o ponto de considerar o administrador culpado (ou seja, já ultrapassou as etapas de verificação da ilicitude e culpabilidade do agente, estabelecendo-as no caso concreto), mas, ainda assim, decide isentar o agente do dever de indenizar. A exclusão, portanto, ocorre a posteriori: todos os elementos do suporte fático são preenchidos, dá-se a incidência da regra e surge o dever de indenizar, mas, por intervenção do juiz, o administrador é isentado do dever de reparar o dano ${ }^{363}$.

No entanto, o fato de não estar a regra do direito norte-americano abarcada pelo artigo $159, \S 6^{\circ}$, não significa que a Lei das S.A. não a tenha recepcionado. Como se verá a seguir, a business judgment rule mostra-se compatível com o conceito de ato regular de gestão, previsto pela primeira parte do caput do artigo 158.

\subsubsection{Uma nova sugestão: a business judgment rule e 0 ato regular de gestão}

Como já exposto no item 3.1.1 desta monografia, a doutrina se vale do conceito de ato irregular de gestão para definir aquele que seria o regular, uma vez que a lei não o faz. De acordo com a segunda parte do caput do artigo 158 da Lei das S.A., o ato irregular de gestão é aquele praticado (i) dentro de suas atribuições ou poderes, com culpa ou dolo; ou (ii) com violação da lei ou do estatuto.

Dessa forma, ato regular de gestão será o contrário disso. Será o ato praticado pelo administrador dentro de suas atribuições e poderes, sem culpa ou dolo, e sem violação da lei ou do estatuto.

Ou seja, será revestido de regularidade o ato que for praticado observando-se o ordenamento jurídico como um todo, o que inclui os deveres de diligência e lealdade (artigos 153 e 155 da Lei das S.A., respectivamente), o

\footnotetext{
363 ADAMEK, Marcelo Vieira von. Responsabilidade Civil dos Administradores de S/A e as ações correlatas. São Paulo: Saraiva, 2009. p. 287.
} 
dever de obediência ao interesse social (artigo 154) e a ausência de conflito de interesses (artigo 156).

É nessa linha que entende TAVARES GUERREIRO:

A lei impõe deveres específicos aos administradores, deveres esses que se entroncam na ampla proposição contida no art. 153 , segundo a qual o administrador da companhia deve empregar, no exercício de suas funções, o cuidado e diligência que todo homem ativo e probo costuma empregar na administração de seus próprios negócios. A imposição de tais deveres, pela lei, apresenta conteúdo nitidamente finalístico, como se infere do art. 154, uma vez que a atividade dos administradores só se legitima na medida em que se dirige à consecução dos fins sociais, no interesse da companhia, satisfeitas, ainda, as exigências do bem público e da função social da empresa.

Consequentemente, será ato irregular de gestão todo aquele que resultar da infração de dever legal do administrador, qualquer que seja. Assim, exempli gratia, se o diretor contrair obrigação lesiva ao interesse social, estará, ipso facto, infringindo o dever estatuído no art. 153, de tal sorte que, comprovada a falta de cuidado e diligência que todo homem ativo e probo costuma empregar na administração de seus próprios bens, responderá o diretor pela obrigação contraída, configurando-se, na espécie, ato irregular de gestão ${ }^{364}$.

Assim sendo, pelo que se demonstrará a seguir, percebe-se que a norma do artigo 158, no sentido de que o administrador não será responsabilizado por ato regular de gestão, é plenamente compatível com os elementos da business judgment rule $e^{365}$.

Em primeiro lugar, como já dito, a regra norte-americana, para ser aplicada, exige que o administrador tenha tomado uma decisão negocial, ainda que tal decisão seja por não agir. Isso se justifica na medida em que o administrador que não tomar nenhuma decisão quando necessário se dará por omisso e, consequentemente, negligente.

No direito brasileiro, essa conduta caracteriza infração ao dever de diligência, previsto no artigo 153 da Lei das S.A., como já decidiu a CVM, no âmbito do Processo Administrativo Sancionador CVM nº RJ2005/8542:

\footnotetext{
364 TAVARES GUERREIRO, José Alexandre. Responsabilidade dos Administradores de Sociedades Anônimas. Revista de Direito Mercantil, n. 42, abr./jun. 1981, p. 74. Grifos nossos.

${ }^{365}$ Confira-se, nesse sentido, o estudo realizado na PUC-Rio em que se desenvolveu a tese a ser exposta neste item: BRIGAGÃO, Pedro Henrique Castello; DA COSTA, Gabriel Carvalho; FERNANDES, Renata; FRANÇA, Luiz Felipe; PRATES, Nathalia; VIEIRA, Victor. O Dever de Diligência dos Administradores de Sociedade Anônima. Relatório Anual PIBIC 2012. Pontifícia Universidade Católica do Rio de Janeiro - PUC-Rio.
} 
(...) o Indiciado confessou que não exerceu qualquer ponderação, censura, reparo, revisão, análise ou julgamento sobre as decisões de realizar as operações discutidas neste processo e, o que é pior, confirmou sua total alienação ao processo, ao imputar a decisão de compra dos ativos a terceiro não contratado (ou habilitado) para a função. Enfim, confessou a falta de diligência e, portanto, eu já poderia concluir aqui pela sua condenação, especialmente porque essa alienação ao processo decisório não é desmentida nas defesas, nem nelas se traz argumentos para relativizar a falta da diligência assumida explicitamente na resposta acima transcrita ${ }^{366}$.

A não tomada de uma decisão negocial, então, configura um ato irregular de gestão e não recebe a proteção da business judgment rule. O elemento decisão negocial, portanto, é comum à regra e ao conceito de ato regular de gestão.

$\mathrm{O}$ segundo elemento da business judgment rule (desinteresse $\mathrm{e}$ independência) leva em conta a atuação de um administrador desinteressado e independente.

Como entendido nos casos Aronson v. Lewis ${ }^{367}$, Sinclair Oil Corp. v. Levien $^{368}$, Cheff v. Mathes ${ }^{369}$ e David J. Greene \& Co. v. Dunhill International, Inc. ${ }^{370}$, para que sejam considerados desinteressados,

directors can neither appear on both sides of a transaction nor expect to derive any personal financial benefit from it in the sense of self-dealing, as opposed to a benefit which devolves upon the corporation or all stockholders generally ${ }^{371}$.

No direito brasileiro, esse conceito corresponde ao dever dos administradores de obediência ao interesse social, previsto no artigo 154 da Lei das S.A., e o de evitar conflitos de interesses, abarcado pelo artigo 156 da mesma lei. Dessa forma, agindo com interesses conflitantes com os da sociedade, o administrador não cumprirá com o disposto em tais dispositivos ${ }^{372}$.

\footnotetext{
${ }^{366}$ Processo Administrativo Sancionador CVM nº RJ2005/8542, Rel. Pedro Oliva Marcilio de Sousa, j. em 29 ago. 2006. Apesar de se tratar de caso envolvendo a administração de fundo de investimento, o conceito do dever de diligência abarcado é o mesmo que aquele previsto pela Lei das S.A., tendo inclusive sido utilizado como base para a decisão do Colegiado.

367 Aronson v. Lewis, 437 A.2d 812.

368 Sinclair Oil Corp. v. Levien, Del.Supr., 280 A.2d 717, 720 (1971).

${ }^{369}$ Cheff v. Mathes, Del.Supr., 199 A.2d 548, 554 (1964).

${ }^{370}$ David J. Greene \& Co. v. Dunhill International, Inc., Del.Ch., 249 A.2d 427, 430 (1968).

371 Aronson v. Lewis, 437 A.2d 812.

372 Nessa direção, NOVAES aponta que o administrador que agir em desacordo com o artigo 156 não será protegido pela regra: "Para se proteger de alegações de que faltou com o dever de diligência, o administrador deve agir sob os seguintes princípios: (...) (iii) Decisão desinteressada. A decisão não trazia um benefício direto ou indireto para o administrador. Se houver conflito, aplica-se o princípio
} 
Já no que se refere à independência do administrador, veja-se o que se entendeu no caso Telxon Corp. v. Meyerson:

Theoretically, a director can be "controlled" by another, for purposes of determining whether the director lacked the independence necessary to consider the challenged transaction objectively. A controlled director is one who is dominated by another party, whether through close personal or familial relationship or through force of will ${ }^{373 / 374}$.

Trata-se de conceito compatível com o disposto no artigo $154, \S 1^{\circ}$, da

Lei das S.A.: "o administrador eleito por grupo ou classe de acionistas tem, para com a companhia, os mesmos deveres que os demais, não podendo, ainda que para defesa do interesse dos que o elegeram, faltar a esses deveres".

\section{Comentando esse dispositivo, EIZIRIK diz:}

A norma contida no $\S 1^{\circ}$ apresenta grande relevância, ao vincular de maneira clara a atividade do administrador à realização do interesse social, independentemente de quem o elegeu para o cargo. Isso porque, o administrador, embora possa ser eleito por determinado grupo de acionistas, não deve qualquer tipo de lealdade aos seus "eleitores", na medida em que não os representa, estando vinculado à realização do interesse social e da finalidade lucrativa da companhia.

(...)

Os administradores não são mandatários da sociedade, muito menos de seus "eleitores"; a companhia faz-se presente, com todos os seus integrantes - acionistas e empregados - por seu intermédio. Assim, uma vez eleitos, devem agir como órgãos, no interesse da sociedade. Caso o administrador favoreça determinados acionistas, controladores ou minoritários, que o elegeram, estará praticando ato em desvio de poder, podendo ser responsabilizado. Com efeito, os poderes que detém devem ser utilizados unicamente

do $\square$ dever de lealdade (art. 155 e art. 156 LSA). Estes princípios formam a 'Regra de Decisão Negocial', semelhante à Business Judgement Rule americana" NOVAES, Ana. Derivativos e Governança Corporativa: O Caso Sadia - Corrigindo o Que Não Funcionou. Disponível em $<$ http://www.economia.puc-

rio.br/mgarcia/Seminario/textos_preliminares/101705\%20Derivativos\%20e\%20Governan\%C3\%A7a\% 20Corporativa.pdf $>$. Acesso em 5 nov. 2013. p. 11.

373 Telxon Corp. v. Meyerson, 802 A.2d 257, 264 (Del. 2003). A mesma decisão, ainda, complementa com o seguinte: "A director may also be deemed "controlled" if he or she is beholden to the allegedly controlling entity, as when the entity has the direct or indirect unilateral power to decide whether the director continues to receive a benefit upon which the director is so dependent or is of such subjective material importance that its threatened loss might create a reason to question whether the director is able to consider the corporate merits of the challenged transaction objectively".

${ }^{374}$ Citando diversos outros casos norte-americanos, assim entendeu a Corte de Delaware no caso Orman v. Cullman 794 A.2d 5 (2002): "To raise a question concerning the independence of a particular board member, a plaintiff asserting the 'control of one or more directors must allege particularized facts manifesting 'a direction of corporate conduct in such a way as to comport with the wishes or interests of the corporation (or persons) doing the controlling.' The shorthand shibboleth of 'dominated and controlled directors' is insufficient.' This lack of independence can be shown when a plaintiff pleads facts that establish 'that the directors are beholden to [the controlling person] or so under their influence that their discretion would be sterilized."” 
para a consecução dos fins sociais, não podendo deles apartar-se para proteger os interesses daqueles que os elegeram ${ }^{375}$.

O elemento desinteresse e independência, então, se encaixa perfeitamente no disposto nos artigos 154 , caput e $\$ 1^{\circ}$, e 156 da Lei das S.A., sendo, consequentemente, compatível com o conceito de ato regular de gestão.

Outro elemento da business judgment rule, o diligência determina que, para ser protegido pela regra, o administrador deve estar munido de informações quando da tomada de decisão. Isto é, ele deve se informar a respeito de todo material razoavelmente disponível ${ }^{376}$.

No direito brasileiro, doutrina e jurisprudência entendem que o dever de se informar constitui um dos aspectos do dever de diligência dos administradores de sociedades anônimas. Conforme PARENTE, “(...) os administradores possuem a obrigação de reunir o maior número de informações possível a respeito da matéria relacionada com as decisões que pretendem adotar" ${ }^{\prime 377 / 378 . ~}$

Dessa forma, como já entendeu a CVM, "uma das formas pelas quais se analisa se o administrador foi ou não diligente é verificando se a decisão negocial foi ou não informada" ${ }^{379}$. Com isso, não há dúvidas de que o dever de diligência equivale ao elemento diligência da business judgment rule, mostrando-se mais uma compatibilidade entre este instituto e o ato regular de gestão.

\footnotetext{
375 EIZIRIK, Nelson. A Lei das S/A Comentada. vol. II. São Paulo: Quartier Latin, 2011. p. 360-361.

${ }^{376}$ Conforme entendido no caso Aronson v. Lewis 473 A.2d 805 (1984), “(..) to invoke the rule's protection directors have a duty to inform themselves, prior to making a business decision, of all material information reasonably available to them. Having become so informed, they must then act with requisite care in the discharge of their duties". O mesmo se extrai do caso Smith v. Van Gorkom 488 A.2d 858 (Del. 1984): “(...) a director's duty to exercise an informed business judgment is in the nature of a duty of care, as distinguished from a duty of loyalty".

377 PARENTE, Flávia. O Dever de Diligência dos Administradores de Sociedades Anônimas. Rio de Janeiro: Renovar, 2005. p. 111.

${ }^{378}$ Nas palavras de RIBEIRO: “o dever de diligencia exige que o administrador deva estar munido das informações necessárias (...), em especial, aquelas relevantes e razoavelmente disponíveis” RIBEIRO, Renato Ventura. Dever de diligência dos administradores de sociedades. São Paulo: Quartier Latin, 2006. p. 226 e 227.

379 Processo Administrativo Sancionador CVM n ${ }^{\circ}$ RJ2005/0097, Rel. Maria Helena Santana, j. em 15 mar. 2007.
} 
Finalmente, parece ser o elemento boa-fé, assim como os demais, plenamente compatível com o conceito de ato regular de gestão. Em primeiro lugar, o próprio artigo 158, no inciso I, determina que o administrador praticará ato irregular de gestão ao agir, dentro de suas atribuições e poderes, com culpa ou dolo. Não se deve esquecer, ainda, que a hipótese prevista no inciso II desse artigo também exige a presença de culpa ou dolo para configurar a irregularidade de um ato praticado, apesar de ser um caso de presunção relativa.

Nessa linha, infere-se que o ato regular de gestão exige a boa-fé.

Mas não é só isso. Determina a Lei das S.A. que o administrador tem dever de lealdade para com a companhia e seus acionistas, conforme versa o artigo $155^{380}$. A esse respeito, PARENTE assevera o seguinte:

No artigo 155, a Lei das Sociedades Anônimas estabelece o dever de lealdade (...), segundo o qual o administrador, na condução dos negócios sociais, deverá exercer seus poderes de boa-fé, tendo em vista os interesses da sociedade e não os seus próprios interesses ou os interesses de outras pessoas, isto é, o administrador não pode se utilizar da posição que ocupa na companhia para obter qualquer tipo de benefício para si ou para terceiros ${ }^{381 / 382}$.

\footnotetext{
${ }^{380}$ Art. 155. O administrador deve servir com lealdade à companhia e manter reserva sobre os seus negócios, sendo-lhe vedado:

I - usar, em benefício próprio ou de outrem, com ou sem prejuízo para a companhia, as oportunidades comerciais de que tenha conhecimento em razão do exercício de seu cargo;

II - omitir-se no exercício ou proteção de direitos da companhia ou, visando à obtenção de vantagens, para si ou para outrem, deixar de aproveitar oportunidades de negócio de interesse da companhia;

III - adquirir, para revender com lucro, bem ou direito que sabe necessário à companhia, ou que esta tencione adquirir.

$\S 1^{\circ}$ Cumpre, ademais, ao administrador de companhia aberta, guardar sigilo sobre qualquer informação que ainda não tenha sido divulgada para conhecimento do mercado, obtida em razão do cargo e capaz de influir de modo ponderável na cotação de valores mobiliários, sendo-lhe vedado valer-se da informação para obter, para si ou para outrem, vantagem mediante compra ou venda de valores mobiliários.

$\S 2^{\circ} \mathrm{O}$ administrador deve zelar para que a violação do disposto no $\S 1^{\circ}$ não possa ocorrer através de subordinados ou terceiros de sua confiança.

$\S 3^{\circ}$ A pessoa prejudicada em compra e venda de valores mobiliários, contratada com infração do disposto nos $\S \S 1^{\circ}$ e $2^{\circ}$, tem direito de haver do infrator indenização por perdas e danos, a menos que ao contratar já conhecesse a informação.

§ 40 É vedada a utilização de informação relevante ainda não divulgada, por qualquer pessoa que a ela tenha tido acesso, com a finalidade de auferir vantagem, para si ou para outrem, no mercado de valores mobiliários.

${ }^{381}$ PARENTE, Flávia. O Dever de Diligência dos Administradores de Sociedades Anônimas. Rio de Janeiro: Renovar, 2005. p. 150. Grifo nosso.

${ }^{382}$ No mesmo sentido, EIZIRIK diz o seguinte: “inspirada nos sistemas jurídicos inglês e norteamericano, introduziu em nosso regime societário o padrão de lealdade (standard of loyalty) que requer do administrador uma conduta de boa-fé e sempre no melhor interesse da companhia" EIZIRIK, Nelson. A Lei das S/A Comentada. vol. II. São Paulo: Quartier Latin, 2011. p. 366.
} 
Assim, diante de todo o exposto neste item, conclui-se que todos os elementos da business judgment rule são plenamente compatíveis com o conceito de ato regular de gestão. Com isso, ao dispor, na primeira parte do caput do artigo 158, que “o administrador não é pessoalmente responsável pelas obrigações que contrair em nome da sociedade e em virtude de ato regular de gestão", a Lei das S.A. recepciona a mencionada regra ${ }^{383}$.

Não se trata de uma "tropicalização" 384 da regra e nem da recepção de apenas de alguns de seus elementos. Ao contrário do $\S 6^{\circ}$ do artigo 159, a não responsabilização do administrador por ato regular de gestão abarca todo o conceito e a aplicabilidade da business judgment rule.

A função do referido $\$ 6^{\circ}$, contudo, não pode ser esquecida. Isto é, além de prever a regra da decisão negocial, o direito brasileiro ainda possibilita ao juiz excluir a reponsabilidade daquele administrador que, por não ter atuado diligentemente, não foi protegido pela business judgment rule.

Reconhece a lei, aqui, a importância e a dificuldade de aplicação prática do dever de diligência na atividade de administração de companhias ao não isentar o administrador de qualquer responsabilidade, mas dando ao juiz o poder de, diante do caso concreto, decidir se ele deverá ou não ser responsabilizado por uma falta de diligência.

Enfim, analisada a recepção da business judgment rule pela Lei das S.A., é importante entender como os órgãos julgadores e reguladores brasileiros vêm julgando os casos em que uma decisão negocial de um administrador de companhia está em foco. Os próximos itens, assim, tratarão da atuação da CVM,

383 Nesse sentido entendeu o diretor da CVM Marcos Barbosa Pinto no âmbito do Processo Administrativo Sancionador CVM no 08/05: “(...) o art. 158 da lei exime o administrador de responsabilidade por 'ato regular de gestão' e o colegiado da CVM, seguindo a business judgement rule norte-americana, evita o reexame das decisões negociais da administração" Processo Administrativo Sancionador CVM no 08/05, Rel. Eli Loria, j. em 12 dez. 2007.

${ }^{384}$ Expressão utilizada pelo diretor da CVM Luiz Antonio de Sampaio Campos no âmbito do Processo Administrativo Sancionador CVM nº 03/02 (Rel. Norma Jonssen Parente, j. em 12 fev. 2004). 
como órgão regulador do mercado de capitais brasileiro, e do Poder Judiciário quando uma decisão desse tipo é questionada.

\subsection{A aplicação da business judgment rule pela CVM}

Analisando-se os processos administrativos sancionadores da CVM julgados entre 2000 e 2014, percebe-se que o princípio da business judgment rule está bem segmentado na jurisprudência dessa autarquia. Como se verá a seguir, o Colegiado desse órgão, em inúmeros julgados, quando não aplica a regra explicitamente, aplica o seu principal princípio, de que o regulador não deve adentrar no mérito das decisões negociais.

Nesse sentido, o diretor Luiz Antonio de Sampaio Campos, no âmbito do Inquérito Administrativo CVM no RJ2002/1173, ocorrido em 2 de outubro de 2003, já alertava para o fato de que o papel do regulador deve se limitar à análise do processo decisório, e não da decisão negocial e seu mérito:

abra-se aqui um parêntese para esclarecer que os conceitos abertos, os assim chamados standard de conduta como o propalado dever de diligência, o dever de conhecer o seu cliente dentre outros tantos deveres previstos na lei, por não se traduzirem em normas de condutas objetivas, terão que ser examinados no processo administrativo considerando não necessariamente e apenas a melhor conduta, mas sim a razoabilidade da conduta adotada ainda que se possa admitir que outra fosse, na opinião do julgador, mais apropriada ou adequada. É este o ponto de equilíbrio que se impõe aos padrões de conduta, dado a sua falta de objetividade. Além disso, a conduta deve ser examinada considerando o momento em que deveria ser praticada e em quais circunstâncias, no calor dos acontecimentos e não distante dos fatos, comodamente e com a calma atípica ao mundo dos negócios ${ }^{385}$.

Mas a primeira vez em que o Colegiado da CVM ponderou a aplicação da business judgment rule foi em 12 de fevereiro de 2004, no julgamento do Processo Administrativo Sancionador CVM n ${ }^{\circ}$ 03/02 $2^{386}$.

Instaurado com base em reclamações dos acionistas da Lorenz S.A., esse processo teve como objeto averiguar a responsabilidade dos administradores

\footnotetext{
385 Inquérito Administrativo CVM n ${ }^{\circ}$ RJ2002/1173, Rel. Norma Jonssen Parente, j. em 2 out. 2003.

${ }^{386}$ Processo Administrativo Sancionador CVM nº 03/02, Rel. Norma Jonssen Parente, j. em 12 fev. 2004.
} 
dessa companhia no que tange a prática de uma decisão negocial relativa à distribuição de dividendos ${ }^{387}$.

Embora tal distribuição tenha sido aprovada em reunião do conselho de administração e proposta à assembleia geral, os administradores, em razão de insucessos dos negócios da companhia, não realizaram o pagamento dos dividendos dentro do respectivo exercício social.

De acordo com o voto vencedor, do diretor Luiz Antonio de Sampaio Campos, a CVM não poderia responsabilizar administradores pela não distribuição de dividendos dentro da data prevista. Segundo ele, "o não pagamento de uma dívida no vencimento não traz ao acionista e à companhia uma responsabilidade disciplinar"388.

De qualquer modo, Sampaio Campos faz importantes ponderações a respeito da discricionariedade de administradores no exercício de suas funções, afirmando, inclusive, que a Lei das S.A., no artigo 159, teria "tropicalizado" a business judgment rule. Veja-se:

(...) a Lei $\mathrm{n}^{\circ} 6.404 / 76$, , (...) numa "tropicalização" da business judgment rule permite inclusive que se exclua a responsabilidade dos administradores, quando se verificar que estes mesmo violando a lei agiram de boa-fé e no interesse da companhia, conforme diz expressamente o parágrafo $6^{\circ}$ do art. 159 .

Assim, segundo penso, os administradores e os acionistas têm discricionariedade para gerir o caixa da companhia e tomar as decisões que entenderem mais apropriadas ao interesse da companhia. E, nesse sentido, vezes há onde o caixa disponível não é suficiente para fazer face a todas as obrigações da companhia - inclusive com o estado, trabalhadores, credores e acionistas - e nessas hipóteses, dentre as decisões imperfeitas ou possíveis, a administração deverá decidir, discricionariamente, no tocante ao gerenciamento de caixa e o fluxo, a prioridade de pagamentos. A CVM, a meu ver, não deve se imiscuir nessa discricionariedade e, a bem dizer, nem tem este poder ${ }^{389}$.

No ano seguinte, em 2005, a business judgment rule não foi mencionada pelos julgamentos dos processos administrativos sancionadores. Vale destacar,

\footnotetext{
${ }^{387} \mathrm{O}$ diretor de relações com investidores da companhia, o único dos três acusados que não teve sua conduta analisada por conta de uma decisão negocial, foi condenado ao pagamento de multa no valor de $\mathrm{R} \$ 50.000,00$ por não ter divulgado fato relevante informando sobre o não pagamento de dividendos declarados.

388 Processo Administrativo Sancionador CVM n 03/02, Rel. Norma Jonssen Parente, j. em 12 fev. 2004.

${ }^{389}$ Processo Administrativo Sancionador CVM nº 03/02, Rel. Norma Jonssen Parente, j. em 12 fev. 2004.
} 
no entanto, que o então presidente Marcelo Trindade, no julgamento do Processo

CVM nº RJ2004/3098, expressou o entendimento de que “(...) não cabe à CVM questionar a decisão da administração, tomada no interesse da Companhia, que por força de lei cumpre à própria administração da Companhia"390.

Outras decisões do Colegiado nesse mesmo sentido foram proferidas em 2006. Sem explicitamente aplicar a regra do direito norte-americano, a CVM demonstrou estar em linha com o principal pilar da business judgment rule, de que o Estado não deve intervir nas decisões dos administradores.

Assim se deu no julgamento do Inquérito Administrativo Sancionador

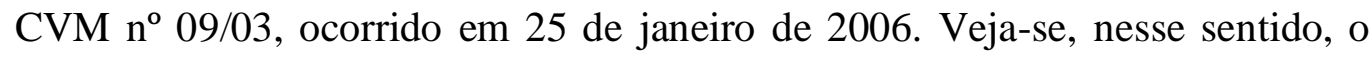
seguinte trecho do voto do diretor relator Wladimir Castelo Branco Castro:

(...) considero que esta CVM somente poderia questionar as decisões e procedimentos dos indiciados na hipótese de seus atos se mostrarem em contrariedade às disposições legais. No entanto, entendo que a decisão de realizar investimentos em uma fábrica é um ato que compete aos gestores da companhia, cabendo a eles a análise sobre a conveniência e oportunidade acerca do que é apontado pelo corpo técnico, para melhor aplicarem os recursos da sociedade.

(...)

Com efeito, entendo que as conclusões da Comissão de Inquérito invadiram o âmbito da gestão industrial, restrita aos administradores da sociedade, vez que a decisão sobre a aplicação dos recursos da companhia - quando não revestida de ilegalidade - é uma matéria de caráter essencialmente empresarial, sendo uma decisão discricionária dos administradores e dos acionistas ${ }^{391}$.

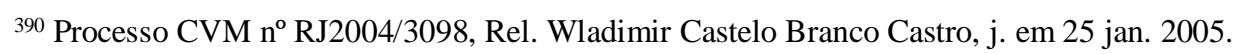

${ }^{391}$ Inquérito Administrativo Sancionador CVM nº 09/03, Rel. Wladimir Castelo Branco Castro, j. em 25 jan. 2006. 
O mesmo se deu nos Processos Administrativos Sancionadores CVM n ${ }^{\circ}$ RJ2005/7229392, RJ2004/5392 ${ }^{393}$ e RJ2005/8542 ${ }^{394}$. Mas deve-se destacar que, em outro processo julgado em 2006, o Colegiado se utilizou expressamente da business judgment rule para embasar a sua decisão. O diretor relator Pedro Oliva Marcilio de Sousa sugeriu, inclusive, que tal regra em nada se diferencia do disposto no artigo 153 da Lei das S.A., podendo ser inteiramente aplicável no direito nacional.

Trata-se do Processo Administrativo Sancionador CVM nº RJ2005/1443, frequentemente citado como parâmetro jurisprudencial em outros julgamentos dessa autarquia:

Para evitar os efeitos prejudiciais da revisão judicial, o Poder Judiciário americano criou a chamada "regra da decisão negocial" (business judgement rule), segundo a qual, desde que alguns cuidados sejam observados, o Poder Judiciário não irá rever o mérito da decisão negocial em razão do dever de diligência. A proteção especial garantida pela regra da decisão negocial também tem por intenção encorajar os administradores a servir à companhia, garantindo-lhes um tratamento justo, que limita a possibilidade de

${ }^{392}$ Processo Administrativo Sancionador CVM n ${ }^{\circ}$ RJ2005/7229, Rel. Marcelo Fernandez Trindade, j. em 10 mai. 2006.

393 “ “...) a atuação da CVM incide sobre o procedimento que levou à tomada da decisão e a eventual benefício das pessoas envolvidas nela. A CVM, portanto, não entra no mérito da decisão.

(...)

[Esse entendimento está em linha] com a abordagem de outras jurisdições e tem como fundamento o fato de os administradores tomarem decisões com base em informações incompletas e relacionadas a eventos, fatos e comportamentos futuros sobre os quais pouco podem influir. Em um tal contexto, a possibilidade da revisão posterior do mérito de uma decisão negocial parece ser inconveniente, pois o "revisor" teria o conjunto completo de informações (desenvolvimento da economia, reação dos consumidores, do governo, dos fornecedores, dos investidores, dos competidores) que não estavam à disposição da administração quando da tomada da decisão. Se essa revisão fosse possível, os administradores teriam dificuldades em tomar decisões que envolvessem risco (i.e., pudessem não ser proveitosas às companhias, embora também tivessem chance de trazer vantagens à ela) e, com isso, seria prejudicada a própria companhia.

Para evitar que essa não revisão do mérito das decisões negociais permita aos administradores tomar decisões em desacordo com o interesse da sociedade, passou-se a rever o processo de tomada de decisão, voltando-se, basicamente, à análise da diligência na tomada de decisão e a lealdade com que os administradores se portam (ou, em outros termos, o desinteresse dos administradores na decisão tomada). Essa forma de revisão das decisões negociais foi reconhecida na lei brasileira das sociedades anônimas, nos arts. 153 a 156" Processo Administrativo Sancionador CVM nº RJ2004/5392, Rel. Pedro Oliva Marcílio de Sousa, j. em 29 ago. 2006.

394 "Na ausência de maior especificação normativa ou de precedentes aplicáveis, parece-me que o nível mínimo deveria ser o do homem ativo e probo, que é o standard previsto para o administrador de companhia aberta. A esse respeito, a CVM vem, conforme corretamente apontado pelos defendentes, tentado evitar a análise do mérito da decisão.

(...)

Pelo que se viu acima, seja com base na Circular 2.616/95, seja com base na Instrução 409/04, o administrador pode ser responsabilizado por falta de diligência e a averiguação da falta de diligência não se vê a partir do mérito da decisão, mas do processo que levou a ela" Processo Administrativo Sancionador CVM nº RJ2005/8542, Rel. Pedro Oliva Marcílio de Sousa, j. em 29 ago. 2006. 
revisão judicial de decisões negociais privadas (e que possa impor responsabilidade aos administradores), uma vez que a possibilidade de revisão ex post pelo Poder Judiciário aumenta significativamente o risco a que o administrador fica exposto, podendo fazer com que ele deixe de tomar decisões mais arriscadas, inovadoras e criativas (que podem trazer muitos benefícios para a companhia), apenas para evitar o risco de revisão judicial posterior. Em razão da regra da decisão negocial, o Poder Judiciário americano preocupa-se apenas com o processo que levou à decisão e não com o seu mérito. Para utilizar a regra da decisão negocial, o administrador deve seguir os seguintes princípios:

(i) Decisão informada: A decisão informada é aquela na qual os administradores basearam-se nas informações razoavelmente necessárias para tomá-la. Podem os administradores, nesses casos, utilizar, como informações, análises e memorandos dos diretores e outros funcionários, bem como de terceiros contratados. Não é necessária a contratação de um banco de investimento para a avaliação de uma operação;

(ii) Decisão refletida: A decisão refletida é aquela tomada depois da análise das diferentes alternativas ou possíveis conseqüências ou, ainda, em cotejo com a documentação que fundamenta o negócio. Mesmo que deixe de analisar um negócio, a decisão negocial que a ele levou pode ser considerada refletida, caso, informadamente, tenha o administrador decidido não analisar esse negócio; e

(iii) Decisão desinteressada: A decisão desinteressada é aquela que não resulta em benefício pecuniário ao administrador. Esse conceito vem sendo expandido para incluir benefícios que não sejam diretos para o administrador ou para instituições e empresas ligadas a ele. Quando o administrador tem interesse na decisão, aplicam-se os standards do dever de lealdade (duty of loyalty).

Existem, no entanto, situações em que, além de operações em que se tenha interesse, o Poder Judiciário não aceita a aplicação da regra da decisão negocial. Por exemplo, não se aceita a completa alienação das decisões negociais, alegando-se falta de competência ou de conhecimento. Também não são protegidas pela regra da decisão negocial as decisões tomadas visando a fraudar a companhia, ou seus acionistas, ou aquelas que não tenham sido tomadas em boa fé.

A construção jurisprudencial norte-americana para o dever de diligência em nada discrepa do que dispõe o art. 153 da Lei 6.404/76, sendo possível utilizar-se, no Brasil, dos mesmos standards de conduta aplicados nos Estados Unidos. A utilização desses standards poderia fazer com que a aplicação do art. 153 fosse mais efetiva do que é hoje, pois poderíamos passar a observar o processo que levou à tomada da decisão para ver se os cuidados mínimos, que demonstram a diligência do administrador, foram seguidos, não nos limitando a simplesmente negar a possibilidade de re-análise do conteúdo da decisão tomada ${ }^{395}$.

Os julgamentos de 2007 demonstram o mesmo entendimento. No Processo Administrativo Sancionador CVM n ${ }^{\text {o }}$ RJ2005/0097396, a diretora relatora Maria Helena de Santana afirma que a área técnica da CVM responsável

\footnotetext{
395 Processo Administrativo Sancionador CVM nº RJ2005/1443, Rel. Pedro Oliva Marcilio de Sousa, j. em 10 mai. 2006.

${ }^{396}$ Processo Administrativo Sancionador CVM n ${ }^{\circ}$ RJ2005/0097, Rel. Maria Helena Santana, j. em 15 mar. 2007.
} 
pela acusação extrapolou o papel dessa autarquia ao considerar que os títulos adquiridos pela companhia em questão contavam com garantias insuficientes.

De acordo com ela, “(...) considerações sobre o mérito de decisões de negócio, em geral, extrapolam o papel do regulador, em sua tarefa de revisão da legalidade dos atos dos administradores de companhia aberta"397.

Essa lógica também foi aplicada aos administradores de fundos de investimento, como se vê no julgamento do Processo Administrativo Sancionador CVM n ${ }^{\circ}$ RJ2005/8510³9, igualmente relatado por Maria Helena de Santana. De acordo com seu voto, "decidir onde e quando investir é decisão do administrador", e este "está sujeito apenas às regras contratadas com os investidores e à obrigação de agir com zelo e visando ao interesse dos investidores"399.

No final de 2007, o diretor Marcos Barbosa Pinto, em seu voto proferido no Processo Administrativo Sancionador CVM n ${ }^{\circ}$ 08/05, constatou que a

\footnotetext{
${ }^{397}$ Processo Administrativo Sancionador CVM n ${ }^{\text {R }}$ 2005/0097, Rel. Maria Helena Santana, j. em 15 mar. 2007. Segue o trecho do voto: "Antes de concluir, gostaria de comentar o que foi utilizado pela SEP como razão principal para caracterizar o cometimento de todas as infrações que entendeu serem imputáveis aos indiciados neste processo. Foi considerado pela área técnica que os títulos adquiridos pela TCO contavam com garantias insuficientes, dadas as informações constantes dos autos a respeito da situação econômico-financeira de seus emissores.

Em minha análise, não considerei essa motivação, nem entendo que isso tenha feito falta, para chegar às conclusões que proponho. Mas, mais que isso, creio que considerações sobre o mérito de decisões de negócio, em geral, extrapolam o papel do regulador, em sua tarefa de revisão da legalidade dos atos dos administradores de companhia aberta. O regulador deve evitar que sua eventual avaliação seja fator que influencie a análise sobre a legalidade da atuação dos administradores, pois pode observar as decisões tomadas por eles em condições de certa forma mais favoráveis, e sem dúvida bastante distintas das que enfrenta o gestor na hora de fazer escolhas.

O gestor de companhia lida com restrições de tempo e de recursos que o levam a dedicar mais ou menos tempo a certas decisões, a realizar estudos mais ou menos aprofundados em cada caso, e isso faz parte de suas responsabilidades. Além disso, ele certamente dispõe de dados que não estão disponíveis para o regulador, os quais considera em suas decisões.

Mas a análise da CVM sobre determinado ato de gestão conta com uma grande vantagem, que não seria justo permitir que fosse usada em prejuízo dos administradores: ela é feita de posse da informação sobre o resultado que o ato acarretou. Se a revisão da legalidade de atos de administração, portanto, puder avançar em aspectos do mérito das decisões, estaremos correndo o risco de reduzir o dinamismo de nossas companhias abertas, pois estará sendo incentivada uma postura extremamente avessa ao risco por parte dos seus administradores". No mesmo sentido, o julgamento do Processo Administrativo Sancionador CVM n 07/03, Rel. Marcelo Trindade, j. em 4 jul. 2007.

${ }^{398}$ Processo Administrativo Sancionador CVM nº RJ2005/8510, Rel. Maria Helena de Santana, j. em 4 abr. 2007.

${ }^{399}$ Processo Administrativo Sancionador CVM nº RJ2005/8510, Rel. Maria Helena de Santana, j. em 4 abr. 2007.
} 
autarquia segue, de fato, o preceituado pela business judgment rule, amparado pelo artigo 158 da Lei das S.A.:

(...) o art. 158 da lei exime o administrador de responsabilidade por "ato regular de gestão" e o colegiado da CVM, seguindo a business judgement rule norte-americana, evita o reexame das decisões negociais da administração ${ }^{400}$.

O referido diretor, entretanto, faz uma ressalva. Para ele, a regra deveria ser afastada em operações de incorporação de companhias controladas, uma vez que são os interesses do acionista que elegeu a maioria dos administradores que acabam prevalecendo.

Sendo assim, ele defende que "existem boas razões para (...) examinar mais a fundo as decisões da administração (...)"401.

Esse entendimento é seguido também pela então diretora presidente Maria Helena de Santana, no âmbito do Processo Administrativo Sancionador CVM n ${ }^{\circ}$ 25/03. Segundo ela, nessas situações, “o julgador [revê] não apenas o processo de decisão, mas também seu mérito, em certa medida"402.

Mas, dentre os casos julgados pela CVM no ano de 2007, um chama mais atenção do que os demais, sendo outro parâmetro jurisprudencial para a aplicação da regra norte-americana: o Processo Administrativo Sancionador $\mathrm{CVM} \mathrm{n}^{\mathrm{o}} 21 / 04^{403}$.

\footnotetext{
${ }^{400}$ Processo Administrativo Sancionador CVM no 08/05, Rel. Eli Loria, j. em 12 dez. 2007.

${ }^{401}$ Processo Administrativo Sancionador CVM no 08/05, Rel. Eli Loria, j. em 12 dez. 2007. "Entre as razões que justificam um reexame mais rigoroso nas incorporações de controladas, as seguintes me parecem particularmente relevantes: (i) a vantagem comparativa dos administradores para tomar decisões em prol do interesse social é menor quando sua independência está comprometida; (ii) a supervisão dos acionistas sobre os administradores normalmente não funciona quando o controlador tem interesse econômico direto na operação; (iii) em um país em que a maioria das empresas tem acionistas majoritários, o mercado de trabalho não incentiva os administradores a adotar uma postura independente em relação aos interesses particulares do controlador; (iv) a possível burocratização do processo decisório da companhia é menos danosa quando estamos diante de operações esporádicas, como a incorporação de controladas; e (v) eventual aversão a risco dos administradores pode ser impedida pelos próprios controladores, que têm interesse direto nessas operações".

${ }^{402}$ Processo Administrativo Sancionador CVM n ${ }^{\circ}$ 25/03, Rel. Eli Loria, j. em 25 mar. 2008.

403 Processo Administrativo Sancionador CVM n 21/04, Rel. Pedro Oliva Marcilio de Sousa, j. em 15 mai. 2007. As referências a outros processos foram omitidas.
} 
O relator do caso, o diretor Pedro Oliva Marcilio de Sousa, expõe e aplica a business judgment rule ao caso concreto. Após discriminar todos os elementos da regra e demonstrar que cada um deles já foi acatado pela CVM, o diretor relator os aplica a cada aspecto do caso concreto.

Veja-se, assim, o seguinte trecho de seu voto:

Neste processo, a principal imputação é a de violação do dever de diligência - art. 153 da Lei 6.404/76. Os termos desse dispositivo enunciam conceitos jurídicos indeterminados, sem especificar critérios para sua aplicação aos casos concretos. Usualmente, as posições doutrinárias sobre esses dispositivos procuram analisar esses conceitos sem, ainda, estabelecer critérios para sua aplicação a casos concretos. Em sua atividade sancionatória, a CVM vem, ao longo do tempo, estabelecendo esses critérios. Entre eles, pode-se citar os seguintes:

(i) se ao administrador for imputado apenas descumprimento do dever de diligência, a CVM não pode entrar no mérito da decisão negocial;

(ii) não há violação ao dever de diligência, quando o administrador toma (ou deixa de tomar) uma decisão, se sua decisão é informada, refletida e desinteressada;

(iii) quando a decisão não for desinteressada, aplicam-se as regras do dever de lealdade (arts. 154 e 155), a partir das quais é possível analisar o mérito da decisão negocial (em outras palavras, o ônus da prova da legitimidade e justeza do ato passa a ser de quem agiu sem observância do dever de lealdade);

(iv) o administrador não pode alegar falta de competência ou conhecimento técnico;

(v) o administrador não pode alienar-se do processo decisório; e

(vi) decisões tomadas sem boa-fé, ou com o intuito de fraudar a companhia ou os investidores não estão protegidas pela regra da decisão negocial - item "i" acima ${ }^{404 / 405}$.

${ }^{404}$ Processo Administrativo Sancionador CVM no 21/04, Rel. Pedro Oliva Marcilio de Sousa, j. em 15 mai. 2007. As referências a outros processos foram omitidas.

${ }^{405}$ Como dito anteriormente, o diretor relator aplica os elementos da business judgment rule aos aspectos do caso concreto, conforme trecho a seguir: "Passo agora a analisar o caso concreto, tentando identificar se a decisão foi desinteressada, refletida e informada:

(i) Decisão Desinteressada: Não há, em qualquer passagem da acusação, qualquer menção a conflito de interesses dos administradores ou à intenção deles de fraudarem o Banco do Brasil, seus acionistas ou de beneficiarem terceiros em prejuízo do Banco do Brasil ou, ainda, à atuação deles sem boa fé. Dessa forma, a revisão das decisões negociais feitas pelos indiciados deve seguir os estritos parâmetros aplicáveis à análise do cumprimento do dever de diligência.

(ii) Decisão Informada. A decisão dos indiciados foi tomada a partir de análises produzidas internamente (Relatório Operacional GETEC 20/2000, Nota GEPAR 00/240, Relatório Operacional GETEC 00/46, Nota FINAN/GEPAC 2000/0427, Relatório Operacional GETEC 00/58, Nota FINAN/GEPAC 2000/0512). A decisão também foi precedida de análises produzidas pelo Banco de Investimento JP Morgan e pela empresa de consultoria McKinsey \& Company (ambos instituições tradicionais e renomadas). A despeito da impropriedade técnica de uma das informações constantes de um estudo interno do Banco do Brasil - a Nota FINAN/GEPAC 2000/0427 teria confundido o valor da empresa com o total de recursos necessários para a execução dos projetos da empresa - essa informação não foi essencial à tomada de decisão, uma vez que o valor do preço por ação do segundo aporte conferia valor de US\$292 milhões à Companhia e não US\$315 milhões como teria erroneamente constado dessa nota. Além do mais, esse erro não pode ser atribuído aos indiciados. As decisões parecem, portanto, ter sido tomadas de forma informada.

(iii) Decisão Refletida. A acusação menciona que a decisão foi objeto de reuniões de diretoria (em 18.05.00, para o primeiro aporte, e em 17.10.00, para o segundo aporte - aqui se fala em despacho e não em reunião, o que, na ausência de maiores esclarecimentos pela acusação, parece indicar a mesma coisa) e que para essas decisões foram feitas diversas análises técnicas, submetidas à consideração dos diretores. 
No ano de 2008, destacam-se os Processos Administrativos Sancionadores CVM no 25/03 ${ }^{406}$, já mencionado acima e que não destoa do entendimento regular da autarquia, e o RJ2007/4476 ${ }^{407}$. A respeito deste último caso, vale mencionar o entendimento do diretor Marcos Barbosa Pinto, no sentido de que a business judgment rule vale com mais força para os administradores independentes. Isto é, a presunção inerente à regra, aplicada em benefício desses administradores, só poderá ser afastada com provas mais detalhadas e contundentes.

Em 2009 e 2010, mantendo o entendimento exposto nos casos passados, a CVM julgou os Processos Administrativos Sancionadores no 14/05 ${ }^{408}$, 18/08 (o caso Sadia, analisado no item 5.4.1 desta monografia) ${ }^{409}$ e RJ2009/2610 ${ }^{410}$.

Em 2012, mais um caso de grande relevância foi julgado pelo Colegiado da autarquia. No julgamento do Processo Administrativo Sancionador CVM n ${ }^{\circ}$ RJ2008/9574, relatado pela diretora Ana Dolores de Novaes, aplicou-se a regra norte-americana diretamente ao caso.

Comparou-se, ainda, o Model Business Corporation Act dos Estados Unidos - onde se tentou codificar a business judgment rule -, com os dispositivos referentes aos deveres fiduciários de administradores de sociedades

Quando da análise do segundo aporte, a diretoria solicitou, inclusive, a produção de um relatório adicional (Nota Operacional GETEC 00/58). A aprovação se deu em acordo com o voto do diretor responsável - o indiciado Vicente de Paulo Diniz. A única indicação que poderia ser tida como contrária ao investimento foi do Relatório Operacional GETEC 20/2000, que, ainda assim, considerou que o negócio, embora não pudesse ser considerado atrativo se analisado isoladamente, poderia o ser, se analisado no contexto da participação societária do Banco do Brasil e suas controladas na Telemar. A conclusão desse relatório operacional sobre a análise individualizada do investimento, no entanto, não foi ratificada pela Nota GEPAR 00/240 (infere-se da acusação de que esta última nota foi produzida por órgão hierarquicamente superior à original). Em razão dos estudos preparados, da sua utilização como material de suporte decisório, da realização de reuniões e estudos complementares, a atuação dos indiciados deve ser tida como refletida.

Por esses motivos, creio não ter havido violação ao dever de diligência pelos indiciados com relação às decisões questionadas pela Comissão de Inquérito" Processo Administrativo Sancionador CVM no 21/04, Rel. Pedro Oliva Marcilio de Sousa, j. em 15 mai. 2007.

${ }^{406}$ Processo Administrativo Sancionador CVM n 25/03, Rel. Eli Loria, j. em 25 mar. 2008.

${ }^{407}$ Processo Administrativo Sancionador CVM nº RJ2007/4476, Rel. Eli Loria, j. em 12 mar. 2008.

${ }^{408}$ Processo Administrativo Sancionador CVM no 14/05, Rel. Eli Loria, j. em 5 mai. 2009.

${ }^{409}$ Processo Administrativo Sancionador CVM no 18/08, Rel. Alexsandro Broedel Lopes, j. em 14 dez. 2010.

${ }^{410}$ Processo Administrativo Sancionador CVM nº RJ2009/2610, Rel. Marcos Barbosa Pinto, j. em 28 set. 2010. 
anônimas previstos pela Lei das S.A. brasileira, concluindo-se que ambos são compatíveis entre $\mathrm{si}^{411}$.

Além disso, como se verá mais detalhadamente no item 5.3.2, ressalte-se que o mesmo caso foi julgado pelo Poder Judiciário. Ao passo em que o juiz de direito condenou os administradores por prejuízos causados em razão de uma decisão negocial, a CVM os absolveu com base na business judgment rule.

Como bem aponta a diretora relatora, a revisão das ações dos administradores ex-post, seja por parte do Poder Judiciário, seja por parte do regulador - a própria $\mathrm{CVM}$-, causaria sérios prejuízos à atividade econômica do país:

A atividade econômica seria seriamente prejudicada se o sistema judiciário e o regulador passassem o tempo todo julgando as ações dos administradores ex-post. É muito fácil apontar que uma decisão foi errada olhando pelo retrovisor do tempo. Mas a essência do mundo dos negócios é tomar riscos. É aplicar o conjunto de informações e crenças que se apresentam em um determinado momento para decidir sobre fatos que gerarão efeitos sobre o futuro da companhia, futuro sobre o qual ninguém tem o controle. É o mercado quem deve corrigir erros reiterados de julgamento da administração, quando tomados de boa-fé, e no que era percebido pela administração da companhia como o melhor para esta. Cabe aos participantes do mercado e aos acionistas removerem administradores, reduzirem sua remuneração, e mesmo castigarem o preço das ações de uma companhia por decisões, tomadas de boa-fé e no interesse da companhia, mas que se apresentaram errôneas ex-post $t^{412}$.

Segue a diretora:

Se as decisões estivessem sempre sob o escrutínio dos reguladores, os administradores e as companhias tomariam decisões não pensando na companhia, mas em como não serem processados. Evidentemente, a inovação, o empreendedorismo, o crescimento econômico e o emprego seriam negativamente $\operatorname{afetados}^{413}$.

\footnotetext{
${ }^{411}$ Nas palavras do voto: "Tanto no Brasil como em outras jurisdições aplica-se um padrão de conduta aos administradores. No nosso caso, este padrão é dado pelo art. 153 da Lei n$^{\circ}$ 6.404/1976 que dispõe:

$\square$ "o administrador da companhia deve empregar, no exercício de suas funções, o cuidado e diligência que todo homem ativo e probo costuma empregar na administração dos seus próprios negócios". $\square$ Este artigo é o núcleo a partir da qual outros padrões de conduta emanam na Lei 6.404/1976: o dever de agir no interesse da companhia (art. 154), o dever de lealdade (art. 155), o dever de não atuar em situações de conflito de interesse (art. 156), e o dever de informar (art. 157).

Este padrão é muito semelhante àquele adotado nos Estados Unidos, pelo Estado de Delaware, onde estão incorporadas grandes companhias americanas, e também pelo Model Business Corporation Act (MBCA) preparado e revisado pela American Bar Association" Processo Administrativo Sancionador CVM n ${ }^{\circ}$ RJ2008/9574, Rel. Ana Dolores Moura Carneiro de Novaes, j. em 27 nov. 2012.

412 Processo Administrativo Sancionador CVM n RJ2008/9574, Rel. Ana Dolores Moura Carneiro de Novaes, j. em 27 nov. 2012.

${ }^{413}$ Processo Administrativo Sancionador CVM n ${ }^{\circ}$ RJ2008/9574, Rel. Ana Dolores Moura Carneiro de Novaes, j. em 27 nov. 2012.
} 
E, finalmente, aplica o princípio da business judgment rule, ao afirmar que

não cabe aos reguladores ou ao judiciário julgar as decisões dos administradores a posteriori, exceto se o padrão de conduta discutido acima foi:

a. afetado por uma situação de conflito de interesses na qual o administrador poderia extrair para si ou para outrem um benefício patrimonial ou facilidade; ou

b. manchado pela evidência de fraude ou má-fé para prejudicar a companhia ${ }^{414}$.

Outros julgamentos importantes, que ajudam a consolidar o entendimento da CVM a respeito da aplicabilidade da business judgment rule no direito brasileiro, foram realizados no ano seguinte, em 2013.

Cite-se, em primeiro lugar, o Processo Administrativo Sancionador CVM $n^{o} 24 / 06^{415}$, em que a acusação da CVM imputa ao indiciado o descumprimento do dever de diligência por não ter supervisionado diligentemente as atividades da companhia.

Diante da alegação da defesa de que o indiciado deveria ser protegido pela business judgment rule, o diretor relator Otavio Yazbek faz uma importante diferenciação entre o dever de diligência relacionado a uma decisão negocial e o dever de diligência relacionado a uma decisão organizacional. Para ele - e os demais membros do Colegiado, que o acompanharam - a regra norte-americana seria aplicável somente ao primeiro caso, o que está de acordo com o exposto no Capítulo 4 desta monografia, especificamente no item 4.2.3.1.

Segundo o seu voto, o dever de diligência previsto no artigo 153 possui duas facetas: "uma de cunho negocial, sujeita ao teste da business-judgment rule; e outra de natureza fiscalizatória, sujeita a uma análise de razoabilidade e de adequação" $" 16 / 417$.

\footnotetext{
${ }^{414}$ Processo Administrativo Sancionador CVM no RJ2008/9574, Rel. Ana Dolores Moura Carneiro de Novaes, j. em 27 nov. 2012.

415 Processo Administrativo Sancionador CVM no 24/06, Rel. Otavio Yazbek, j. em 18 fev. 2013.

${ }^{416}$ Processo Administrativo Sancionador CVM nº 24/06, Rel. Otavio Yazbek, j. em 18 fev. 2013.

${ }^{417}$ Nesse sentido, como visto no item 4.4 desta monografia, o caso In Re Citigroup Inc. Shareholder Derivative Litigation, 964 A.2d 106 (2009).
} 
E, como atesta Yazbek, "aqui estamos tratando com algo diferente de uma decisão negocial - decisões sobre controles internos são decisões organizacionais de outra ordem"^118.

Seguindo esse raciocínio, então, o Colegiado refutou a aplicação da regra ao caso concreto. Porém, é importante destacar, como inteirou o próprio Colegiado, que a CVM não negou a aplicabilidade da business judgment rule no direito brasileiro. O que se fez, na verdade, foi identificar e distinguir os aspectos do dever de diligência aos quais se poderia aplicar tal regra ${ }^{419}$.

Por fim, em julgamento ocorrido poucos dias depois, a autarquia novamente decidiu por não aplicar a business judgment rule. De acordo com o voto da diretora relatora Luciana Dias, no âmbito do Processo Administrativo Sancionador CVM $\mathrm{n}^{\circ} 11 / 02$, isso ocorreu porque, resumidamente, os administradores do Banco do Estado do Paraná S.A. teriam desrespeitado controles internos da companhia e faltado com atenção e reflexão sobre red flags levantadas por esses controles ${ }^{420}$.

Assim, diante dos casos acima mencionados, pode-se notar que a business judgment rule, seus princípios e seus elementos estão fortemente consolidados na jurisprudência da CVM, demonstrando ser a regra inteiramente compatível com o direito brasileiro. Cumpre, agora, analisar como a jurisprudência do Poder Judiciário brasileiro vem tratando as decisões negociais de administradores de sociedades anônimas.

\footnotetext{
418 Processo Administrativo Sancionador CVM nº 24/06, Rel. Otavio Yazbek, j. em 18 fev. 2013.

${ }^{419}$ Nos termos do voto do diretor relator: "Não se está negando a aplicabilidade, ao direito brasileiro, da racionalidade subjacente à business-judgment rule, presente tanto na doutrina quanto nas decisões norteamericanas e mesmo naquelas tomadas por esta autarquia. $\mathrm{O}$ exercício feito acima pretende, apenas, distinguir com maior clareza as hipóteses em que se deve aplicar esta racionalidade (ainda que com alguns temperamentos) de outras cujo reexame reclama ponderações de ordem distinta" Processo Administrativo Sancionador CVM no 24/06, Rel. Otavio Yazbek, j. em 18 fev. 2013.

420 “(...) para análise das operações específicas e afastamento da proteção usualmente conferida pela CVM a decisões negociais, levei em conta: (i) elementos que subvertessem ou burlassem esses controles internos; ou (ii) a falta de atenção e reflexão sobre os red flags que esses controles tenham enviado aos administradores" Processo Administrativo Sancionador CVM nº 11/02, Rel. Luciana Dias, j. em 26 fev. 2013.
} 


\subsection{A aplicação da business judgment rule pelo Poder Judiciário brasileiro}

Os tribunais brasileiros analisaram e decidiram pouquíssimos casos que envolviam o tema da responsabilidade civil dos administradores de sociedades anônimas ${ }^{421}$. Por consequência, a business judgment rule passou ainda menos pelo crivo do Poder Judiciário do país.

$\mathrm{Na}$ verdade, a regra nunca foi expressamente mencionada pelos magistrados. Há, sim, alguns poucos casos envolvendo a análise de uma decisão específica do administrador que teria supostamente desobedecido o seu dever de diligência e/ou lealdade.

Infelizmente, como talvez já se pudesse esperar, os julgadores não souberam analisar a conduta dos administradores à luz da business judgment rule. Não houve a consciência de que o administrador, por estar à frente de um negócio, deve tomar decisões arriscadas que podem vir a causar danos à companhia.

Todo o processo decisório pelo qual passam esses profissionais no cotidiano de suas atividades, brevemente analisado no Capítulo 2, foi sumariamente ignorado. Não se considerou a situação na qual se inseria o administrador, tampouco as informações que detinha ou as alternativas ao seu alcance.

\footnotetext{
${ }^{421}$ Vale trazer a observação (e sutil crítica) de CORRÊA LIMA, no sentido de que matérias envolvendo a responsabilização de administradores são raramente debatidas no Poder Judiciário: "Infelizmente (ou felizmente?) a justiça brasileira tem sido pouco provocada em matéria de responsabilidade de administradores de sociedades comerciais em geral. Várias suposições têm sido formuladas para explicar esse fenômeno: carestia das custas processuais e dos honorários de advogados; morosidade da justiça; falta de treino dos magistrados para lidar com problemas financeiros complexos, o que reduziria a expectativa de decisões justas; relutância em litigar; não inteiramente explicada por todos os fatores acima; desconfiança de que mesmo as decisões justas venham a ser executadas.

Por essas e outras, a contribuição do poder judiciário, nessa área, tem sido, quantitativamente, pequena. É claro que essa limitação quantitativa influi na própria qualidade das decisões. Quanto maior o número de casos num determinado setor do Direito, maiores serão os questionamentos, as pesquisas, os estudos, as reflexões e os insights" CORRÊA LIMA, Osmar Brina. Responsabilidade Civil dos Administradores de Sociedade Anônima. Rio de Janeiro: Aide, 1989. p. 101-102.
} 
O que se fez foi apontar que havia alternativas melhores àquela escolhida e que a esta nunca daria lucros à sociedade. Os julgadores, em uma posição confortável, já conhecendo todos resultados de todas as alternativas que tinham os administradores, entraram no mérito da decisão e, considerando basicamente o dano causado à companhia, os condenaram pelos prejuízos sofridos.

Esse comportamento dos magistrados pôde ser visto em dois casos julgados.

\subsubsection{Apelação Cível no 7.460/04 - "O 'investimento' (...) foi, na realidade, catastrófico, pois são remotas as possibilidades de retorno do vultuoso capital investido"}

A Apelação Cível nº 7.460 foi julgada pela $15^{a}$ Câmara Cível do Tribunal de Justiça do Estado do Rio de Janeiro em 28 de julho de 2004 e teve como relator o desembargador Nilton Mondego de Carvalho Lima. Por meio desse processo, os autores, legitimados extraordinariamente, agindo no interesse da Semenge Engenharia e Empreendimentos S.A., obtiveram de Sebastião Cantidio Drumond, diretor presidente e controlador dessa companhia, o ressarcimento de $\mathrm{R} \$ 12.860 .169,62$, bem como o montante que esse valor renderia se tivesse sido aplicado em instituições financeiras.

Drumond, segundo o acórdão, adquiriu, tanto para a sociedade quanto para ele mesmo, como pessoa física, títulos públicos emitidos no final do século XIX e no início do século XX, o que, conforme a sentença de primeiro grau, seria uma péssima aquisição por ser incerto o retorno do valor investido.

De acordo com o diretor presidente, os títulos, à época de sua aquisição, estavam em franca negociação e valorização no mercado de balcão e teriam sido adquiridos por apenas $17 \%$ do seu valor. Como aponta LAMY FILHO, a compra desses títulos realmente era uma prática do mercado, havendo opiniões doutrinárias tanto a favor quanto contra a sua exigibilidade: 
A aquisição de Títulos da Dívida Pública, para servir de garantia em processo judicial, era, no passado, uma prática de mercado e alguns juristas renomados, estudando o assunto, emitiram pareceres favoráveis ao assunto.

Havia, no entanto, alguns estudiosos que entendiam ser impossível a utilização de tais títulos para esse fim, seja alegando que estariam prescritos, o que comprometia sua validade, seja entendendo que, para fins tributários, eles não poderiam ser utilizados.

Existia, ainda, um parecer da Procuradoria Geral da Fazenda Nacional, de 30 de junho de 1998, contrário à aceitação dos referidos títulos.

Era o assunto, portanto, controvertido e existia, consequentemente, um risco no negócio ${ }^{422}$.

Mas, antes de se discutir o caso, faz-se necessário ressalvar que, independentemente da virtude ou não do investimento e da conduta do diretor presidente para a aquisição dos referidos títulos, o exame, aqui, será concentrado no juízo de valor que o desembargador relator, acompanhado da unanimidade dos demais desembargadores, proferiu a respeito dessa aquisição.

Explique-se: mesmo que outros fatores desse caso possam levar a crer que Drumond realmente poderia ter sido responsabilizado ${ }^{423}$, analisar-se-á somente as declarações do julgador a respeito do mérito do investimento realizado, o que, aparentemente, já o levaria, por si só, a condenar o réu. E, para isso, deve-se lembrar que, como apontado por LAMY FILHO no trecho acima transcrito, tratava-se de tema controverso, com teses tanto favoráveis quanto contrárias.

A ementa do acórdão já denuncia a análise dos desembargadores exclusivamente voltada ao mero insucesso do investimento (quase sempre mencionado entre aspas, querendo o julgador dar a entender que a aquisição dos títulos não poderia nem ser considerada um investimento), sem menção ao correspondente processo decisório. Veja-se:

Responsabilidade Civil. Legitimação da minoria em face de ato lesivo do Administrador de Sociedade Anônima. Aquisição de Títulos da Dívida Pública do século passado e retrasado. Títulos sem cotação em bolsa e só negociados em mercado informal. Ato altamente lesivo aos interesses da sociedade. Procedência do pedido. Inconformismo do réu. Improvimento do recurso ${ }^{424}$.

\footnotetext{
${ }^{422}$ LAMY FILHO, Alfredo. Temas de S.A. Rio de Janeiro: Renovar, 2007. p. 409.

${ }^{423} \mathrm{O}$ réu não conseguiu provar, por exemplo, que os contratos de compra e venda dos títulos públicos teriam sido assinados por dois administradores da Semenge Engenharia e Empreendimentos S.A., como exigido pelo $\S 2^{\circ}$ do art. 15 do estatuto social da companhia.

424 TJRJ, Apelação Cível nº 7.460, Rel. Des. Nilton Mondego de Carvalho Lima, Rio de Janeiro, 18 ago. 2004.
} 
$\mathrm{O}$ ato altamente lesivo aos interesses da sociedade, pela leitura da ementa, parece ser a mera aquisição de títulos da dívida pública sem cotação em bolsa e só negociados em mercado informal. Ignora-se, assim, o exame da diligência, lealdade e obediência ao interesse social por parte do administrador quando da tomada de decisão.

No decorrer do acórdão, o desembargador relator realizou diversos juízos de valor a respeito do investimento. Confundindo os conceitos de culpa stricto sensu e dolo, ele chega, inclusive, ao absurdo de presumir a má-fé do réu por conta do investimento realizado e afirma, ainda, que ninguém, em sã consciência, investiria em títulos dessa natureza. Em suas palavras:

Por outro lado, a falta de boa-fé, aí, está evidente, porque, se tivesse havido "INVESTIMENTO" - e não houve, pois ninguém, em sã consciência, investe em títulos dessa natureza, teria ocorrido evidente negligência do réu na aquisição dos referidos títulos, causando danos à entidade ${ }^{425}$.

Nesse ponto, vale trazer como lição o entendimento da Suprema Corte de Delaware, exposto no caso McPadden v. Sidhu, de que nem a negligência grave - ou gross negligence - pode ser confundida com má-fé:

In analyzing three different categories of fiduciary behavior that are candidates for the "bad faith" pejorative label, the Court made quite clear that gross negligence cannot be such an example of bad faith conduct: there is no basis in policy, precedent or common sense that would justify dismantling the distinction between gross negligence and bad faith. Instead, the Court concluded that conduct motivated by subjective bad intent and that resulting from gross negligence are at opposite ends of the spectrum. The Court then considered a third category of conduct: the intentional dereliction of duty or the conscious disregard for one's responsibilities. The Court determined that such misconduct must be treated as a non-exculpable, non-indemnifiable violation of the fiduciary duty to act in good faith, a duty that the Court later confirmed was squarely within the duty of loyalty. Thus, from the sphere of actions that was once classified as grossly negligent conduct that gives rise to a violation of the duty of care, the Court has carved out one specific type of conduct - the intentional dereliction of duty or the conscious disregard for one's responsibilities - and redefined it as bad faith conduct, which results in a breach of the duty of loyalty. Therefore, Delaware's current understanding of gross negligence is conduct that constitutes reckless indifference or actions that are without the bounds of reason ${ }^{426}$.

425 TJRJ, Apelação Cível no 7.460, Rel. Des. Nilton Mondego de Carvalho Lima, Rio de Janeiro, 18 ago. 2004.

${ }^{426}$ McPadden v. Sidhu, 964 A.2d 1262 (2008). 
De volta ao julgamento, o desembargador afirma, em outro trecho, que "o 'investimento', que teria sido feito pelo réu, foi, na realidade, catastrófico, pois [eram] remotas as possibilidades do retorno do vultuoso capital investido".

Em seguida, analisa a liquidez dos títulos adquiridos:

Prosseguindo com os ensinamentos da citada obra, colhe-se, às fls. 171, no tocante ao conceito de liquidez, que esse termo refere-se "à possibilidade de transformar o valor investido em poder de compra (poder aquisitivo) pronto para o uso".

É óbvio que não há a menor possibilidade na feitura dessa conversão, o que deixa muito clara a falta de liquidez no investimento em apreço ${ }^{427}$.

Finalmente, o desembargador, disparando outro absurdo, conclui que o diretor presidente jogou fora o valor investido porque estava agindo de elevada má-fé - e que, para se chegar a essa conclusão, não seria necessária nem a produção de prova pericial:

Não há dúvida de que nenhum investidor, a não ser se estiver imbuído de elevada máfé, em alguma maquinação fraudulenta, para lesar terceiros, arruinando-se, propositalmente, é que jogará fora a vultosa importância de $\mathrm{R} \$ 12.860 .169,62$.

Para se chegar a essa conclusão, desnecessária seria até a produção de prova pericial ${ }^{428}$.

A única análise sobre a conduta do administrador se limita a um trecho de um manual editado em 1985 pela Comissão Nacional da Bolsa de Valores. O desembargador relator apenas transcreve, desse manual, o que compõe uma análise de investimento e, com isso, conclui que o réu não teria "efetuado tal análise e nem (...) consultado os acionistas para levar a empresa a tão frágil aventura" ${ }^{\prime 29}$.

427 TJRJ, Apelação Cível no 7.460, Rel. Des. Nilton Mondego de Carvalho Lima, Rio de Janeiro, 18 ago. 2004.

428 TJRJ, Apelação Cível no 7.460, Rel. Des. Nilton Mondego de Carvalho Lima, Rio de Janeiro, 18 ago. 2004.

${ }^{429}$ In verbis: “A seguir, referindo-se à avaliação de investimentos, esclarece o referido Manual, que 'A análise de investimento requer, em primeiro lugar, uma estimativa dos rendimentos futuros que o emprego do capital pode proporcionar. Ela compreende o estudo detalhado das características, das qualidades, das perspectivas e do valor de um investimento a ser escolhido. Normalmente compreende, também, um estudo comparativo para que se possa decidir com maior segurança. Uma boa análise de investimento torna-se, portanto, uma tarefa de estimativa e comparação, envolvendo o exame das diversas alternativas'.

Não fez o réu a prova documental de que tivesse efetuado tal análise e nem que tenha consultado os acionistas para levar a empresa a tão frágil aventura”. 
Como se vê, ao adentrar ao mérito da decisão tomada pelo administrador, o magistrado comete um grave equívoco. Em primeiro, porque ele não é especializado na matéria relativa à operação financeira sob exame para determinar o que deveria e o que não deveria ter sido feito. Em segundo, sua análise a respeito da decisão se dá em uma situação diferente: ele já conhece todos os resultados e já sabe qual teria sido o caminho mais correto a ser seguido.

Somente o administrador é competente para determinar se vale tomar certos riscos para realizar um investimento. Não deve o Poder Judiciário tomar esse lugar, como fizeram os desembargadores da $15^{\mathrm{a}}$ Câmara Cível do Tribunal de Justiça do Estado do Rio de Janeiro.

Não obstante, o Tribunal ainda conclui que o administrador teria agido de má-fé porque, em sua visão, o investimento realizado seria de baixíssima qualidade. Uma conclusão dessas não pode ser admitida.

Primeiramente, porque a imputação de dolo deve vir acompanhada de uma demonstração inequívoca de que houve a intenção de se causar dano ao lesado. Sem isso, não se pode afirmar a má-fé.

Em segundo, porque se trata de um extremo desincentivo à atividade de administração de sociedades. Se uma decisão negocial/econômica de insucesso for causa de responsabilização por prejuízos sofridos pela companhia, não haverá mais tomada de riscos e somente aqueles que não se preocupam com o patrimônio próprio se disponibilizarão a exercer tal atividade.

A eficiência das companhias, com isso, seria levada a níveis baixíssimos.

\subsubsection{Processo no 2003.001.047338-0 - "A emissão pública das ações não foi vantajosa para as sociedades (...)"}

Os autores Caixa de Previdência dos Funcionários do Banco do Brasil PREVI, Fundação dos Economiários Federais - FUNCEF, Fundação Banco Central de Previdência Privada - Centrus, Fundação Vale do Rio Doce de 
Seguridade Social - VALIA e Fundação Embratel de Seguridade Social TELOS, por meio desse processo, buscavam a condenação dos administradores da Opportunity Zein S.A. e da Futuretel S.A., Verônica Valente Dantas Rodenburg, Eduardo Penido Monteiro e Maria Amália Delfim de Melo Coutrim, e do Banco Opportunity S.A.

Segundo os autores, os réus seriam responsáveis pela realização de oferta pública de ações emitidas pela Opportunity Zain S.A. e Futuretel S.A. que, no seu entender, seria desnecessária, pois poderia ter se dado de forma privada, sem todos os custos de uma oferta ao mercado. Isso porque todas as ações emitidas foram subscritas por antigos acionistas e o esforço de captação de recursos poderia ter sido feito pelos próprios administradores das sociedades junto a tais acionistas, sem necessidade de pagamento de comissão ao intermediador, o Banco Opportunity S.A.

Apontam também que a Resolução CMN nº 2.324/96, que disciplinava a aplicação de recursos por entidades fechadas de previdência social, a despeito do fato de que vedava a realização de operações com títulos, valores mobiliários e demais ativos financeiros e/ou modalidades operacionais, permitia a subscrição de ações em decorrência do exercício de direito de preferência. Assim, a oferta privada a esses entes não seria proibida.

Alegam, ainda, que o Banco Opportunity S.A., administrador do CVC FIA (acionista das companhias), teria deliberado a assinatura de contrato de intermediação de oferta pública com ele mesmo por meio de conselheiros que teria nomeado (os demais réus) e, por conta disso, esses administradores teriam atuado com interesses conflitantes.

Em sua defesa, os réus alegam que os recursos captados por meio da oferta pública eram necessários para o pagamento da primeira parcela do preço de aquisição das companhias Brasil Telecom S.A., Telemig S.A. e Tele Norte Celular S.A. Esperavam, com essa oferta, atrair investidores do porte de entidades de previdência privada e fundos de investimento. Fora isso, ainda havia 
incerteza a respeito de um aporte de capital para pagar as parcelas seguintes da mencionada aquisição.

Afirmaram também que o direito de preferência havia sido excluído e, quanto ao contrato firmado com o Banco Opportunity, este foi o único a aceitar o encargo em tempo mínimo, tendo cobrado as menores taxas do mercado.

Diante disso, analisando-se a sentença proferida pelo juízo de direito da $8^{\text {a }}$ Vara Empresarial da Comarca da cidade do Rio de Janeiro, verifica-se que todo o exame da conduta dos administradores se deu com base no que aconteceu posteriormente à tomada de decisão.

Em primeiro lugar, o juiz ignora o fato do direito de preferência ter sido excluído e afirma que não havia óbice à realização de oferta privada, tendo em vista a exceção da Resolução CMN nº 2.324/96. Em segundo, aponta que o argumento de que a oferta pública teria sido realizada para captar novos investidores não seria procedente, uma vez que somente os acionistas das companhias subscreveram as ações ofertadas.

Assim, entendendo que a oferta pública teria sido desnecessária, o juiz conclui que os administradores agiram com abuso de poder:

Verifica-se que os administradores agiram com abuso de poder, uma vez que atuaram de forma contrária ao interesse social. A emissão pública das ações não foi vantajosa para as sociedades, mas somente para o Banco Opportunity, que, além de ser o administrador do Fundo CVC, intermediou o ato ${ }^{430}$.

Sobre a atuação dos administradores em suposto conflito de interesses, $o$ julgador entendeu que, por terem sido nomeados pelo Banco Opportunity S.A., os administradores réus teriam interesse particular e direto no caso. Veja-se:

Manifesta, ainda, a ocorrência de conflito de interesses entre o Conselho de Administração e a instituição contratada para coordenar a colocação pública da emissão. Isso porque, além dos membros do Conselho de Administração figurarem como executivos do grupo do qual pertence o Banco Opportunity, foram nomeados pelo próprio Banco, e, dessa forma, tiveram interesse particular e direto na sua contratação. A falta de abstenção do voto, no sentido de se contratar diversa instituição,

430 Oitava Vara Empresarial da Comarca da Capital do Estado do Rio de Janeiro, Processo $\mathrm{n}^{\circ}$ 2003.001.047338-0, Juiz de Direito Alexander dos Santos Macedo, Rio de Janeiro, 14 dez. 2004. 
contribui para que se conclua que a emissão pública somente se realizou para favorecer o Banco Opportunity ${ }^{431}$.

O juiz, então, condenou os réus a ressarcirem os autores da quantia paga a título de comissão ao Banco Opportunity S.A. no valor de $\mathrm{R} \$ 1.552 .618,09$, relativo à Opportunity Zein S.A., e R\$378.658,50, relativo à Futuretel S.A.

Ocorre que o mesmo caso foi julgado pelo Colegiado da CVM em 27 de novembro de 2012. Trata-se do Processo Administrativo Sancionador CVM n ${ }^{\circ}$ RJ2008/9574, de relatoria da diretora Ana Dolores de Novaes, instaurado em face de Verônica Valente Dantas Rodenburg, Eduardo Penido Monteiro e Maria Amália Delfim de Melo Coutrim - o Banco Opportunity S.A. não se encontra no rol de acusados.

É possível, com isso, observar uma grande diferença entre o nível técnico do Poder Judiciário e do Colegiado da autarquia quando da aplicação da business judgment rule. Aplicando essa regra, o Colegiado da CVM absolve todos os administradores.

A primeira acusação refutada é a existência de conflito de interesses. De acordo com a diretora relatora, a taxa aplicada pelo Banco Opportunity S.A. (de $1,1 \%$ ) estava dentro dos padrões de mercado. Não haveria, assim, qualquer conflito de interesses na contratação do banco.

Nas palavras de seu voto,

em nenhum momento, ao longo dos 21 volumes e mais de 4.500 páginas deste processo, demonstrou-se que os Defendentes se beneficiaram, direta ou indiretamente, patrimonialmente, de tal decisão, ou que ainda beneficiaram a outrem ${ }^{432}$.

E, como bem ressalta a diretora relatora, a absolvição dos acusados poderia ser resultado puro e simples da ausência de conflito de interesses.

\footnotetext{
431 Oitava Vara Empresarial da Comarca da Capital do Estado do Rio de Janeiro, Processo $\mathrm{n}^{\circ}$ 2003.001.047338-0, Juiz de Direito Alexander dos Santos Macedo, Rio de Janeiro, 14 dez. 2004.

432 Processo Administrativo Sancionador CVM no RJ2008/9574, Rel. Ana Dolores Moura Carneiro de Novaes, j. em 27 nov. 2012.
} 
Contudo, ela continua e analisa a diligência dos administradores quando da tomada de decisão. Considerando as circunstâncias em que o aumento de capital ocorreu (dentre elas a possibilidade dos acionistas originais não o subscreverem e a necessidade de pagamento da $1^{\mathrm{a}}$ parcela da aquisição das companhias de telefonia), a julgadora formula as seguintes perguntas:

Será que se eu fosse conselheira destas companhias, precisasse levantar recursos da ordem de $\mathrm{R} \$ 1,7$ bilhão, e diante das circunstâncias acima, optaria necessariamente por emissão restrita aos acionistas originais? Será que nas circunstâncias acima descritas, seria razoável acreditar que haveria o risco, mesmo que reduzido, de os acionistas originais se recusarem a subscrever a totalidade do aumento de capital ${ }^{433}$ ?

As respostas, segundo ela, seriam não e sim, respectivamente. Os administradores acusados, em sua opinião, teriam tomado a decisão que acreditavam ser no melhor interesse das companhias. Não caberia ao órgão regulador, portanto, puni-los em razão de ter havido uma alternativa que se mostraria melhor posteriormente.

Assim, comparando-se os dois julgamentos, pode-se ver que o juiz de direito, olhando para o passado e conhecendo todos os resultados de todas as opções de ação ao alcance dos administradores, entrou no mérito da decisão negocial e os condenou por terem causado prejuízos à companhia. Além disso, declarou ter havido conflito de interesses - e, portanto, interesse direto dos administradores na negociação - pelo simples fato de que eles administravam outras companhias do mesmo grupo do Banco Opportunity S.A. e que teriam sido por ele nomeados. Não há, assim, qualquer ponderação a respeito das condições equitativas e razoáveis de celebração do contrato.

O Colegiado da CVM, em contrapartida, não entrou no mérito da decisão tomada. Em vez de examinar a conduta dos acusados com base nos resultados já conhecidos, os diretores se colocaram na posição dos administradores e analisaram se estes agiram visando ao interesse das companhias. Uma vez concluído que a atuação se deu de boa-fé, diligentemente e no interesse da

\footnotetext{
${ }^{433}$ Processo Administrativo Sancionador CVM n ${ }^{\circ}$ RJ2008/9574, Rel. Ana Dolores Moura Carneiro de Novaes, j. em 27 nov. 2012. Grifos do original.
} 
companhia quando da tomada de decisão, o Colegiado aplicou - corretamente a business judgment rule e absolveu os acusados.

Portanto, diante do estudo dos dois casos julgados pelo Poder Judiciário brasileiro apresentados acima, pode-se concluir que o tema da responsabilidade dos administradores de companhias está longe de ser dominado pelos magistrados. Ao invés do que determina a business judgment rule, a presunção imediata dos magistrados foi a de que os administradores agem de má-fé na condução dos negócios de uma companhia.

O efeito disso, caso essas decisões se tornem comuns, será um extremo desincentivo à administração de sociedades anônimas. Administradores probos e honestos, quando não se afastarem dessa atividade, tomarão decisões visando a, principalmente, não serem civilmente responsabilizados. O risco, assim, seria sempre evitado e o lucro e o desenvolvimento da economia, por consequência, reduzidos.

\subsection{A business judgment rule e a crise dos subprime}

Antes de pôr fim ao presente trabalho, é interessante trazer, ainda, na linha da análise de julgamentos envolvendo a business judgment rule, como a regra norte-americana foi aplicada em casos originados no âmbito da mais recente crise financeira que abalou todo o planeta: a crise de 2008, também conhecida como a crise dos subprime.

Nos anos anteriores a 2008, as instituições financeiras norte-americanas, frente à alta nos preços dos imóveis dos Estados Unidos, passaram a conceder empréstimos em grande escala para tomadores com históricos ruins de adimplência, que, com isso, adquiririam os imóveis (os créditos subprime). A única garantia exigida para o pagamento do crédito era a hipoteca do próprio imóvel. 
Entretanto, com o colapso da bolha especulativa do mercado imobiliário norte-americano, os preços dos imóveis despencaram. Os créditos não foram pagos e aqueles que neles investiram sofreram prejuízos de ordens imensuráveis.

Como expõe NOVAES,

o "annus horribilis" de 2008 viu incrédulo o desaparecimento de instituições financeiras nos Estados Unidos, antes consideradas verdadeiras fortalezas do sistema financeiro, bem como presenciou companhias tradicionais entrarem com pedido de recuperação judicial ou, simplesmente, falindo ${ }^{434}$.

Visto isso, dois casos julgados (um brasileiro e outro americano) chamam a atenção, descritos e analisados a seguir.

\subsubsection{O Caso Sadia}

No Brasil, muitas companhias que estavam expostas a oscilações cambiais sofreram grandes prejuízos com o aumento inesperado do dólar. Nesse cenário, o caso Sadia se destaca ${ }^{435}$.

Tal caso foi julgado tanto pela CVM quanto pelo Judiciário. Na autarquia, trata-se do Processo Administrativo Sancionador $n^{\circ}$ 18/08, de relatoria do diretor Alexsandro Broedel Lopes, decidido em 14 de dezembro de 2010. No Poder Judiciário, o caso chegou ao STJ, dando origem ao julgamento do Recurso Especial no $1.313 .725-\mathrm{SP}^{436}$.

A Sadia S.A. era uma grande companhia aberta que tinha como objeto a produção e distribuição de alimentos refrigerados e congelados para varejistas da América Latina, Oriente Médio, Ásia e Europa. Como muitas companhias exportadoras, a companhia investiu em hedging cambial atrelado à variação entre

\footnotetext{
${ }^{434}$ NOVAES, Ana. Derivativos e Governança Corporativa: O Caso Sadia - Corrigindo o Que Não Funcionou. Disponível em <http://www.economia.pucrio.br/mgarcia/Seminario/textos_preliminares/101705\%20Derivativos\%20e\%20Governan\%C3\%A7a\% 20Corporativa.pdf>. Acesso em 5 nov. 2013. p. 1.

${ }^{435}$ Além do caso Sadia, o caso Aracruz também entrou em evidência, mas não foi a julgamento. Os acusados assinaram termos de compromisso com a CVM, tendo o diretor financeiro, responsável direto pelas operações financeiras, pago $\mathrm{R} \$ 1.500 .000,00$, sendo metade do valor à autarquia e a outra metade ao Fundo de Defesa dos Direitos Difusos. No Judiciário, nenhuma ação contra os administradores foi a julgamento.

436 STJ, REsp n. 1313725-SP, Rel. Ministro Ricardo Villas Bôas Cueva, Brasília, 29 jun. 2012.
} 
o dólar e o real. Com isso, visava a mitigar prejuízos com a oscilação de moedas estrangeiras.

Esse investimento, no entanto, passou a gerar enormes lucros à sociedade. De acordo com o relatório do processo administrativo da CVM, os ganhos financeiros com os derivativos, nos seis anos que antecederam a crise de 2008, foram de aproximadamente $\mathrm{R} \$ 1,6$ bilhão, o que representa surpreendentes $47 \%$ do resultado da Sadia nesse período.

Ou seja, apesar de sua atividade principal, à época, ser a produção e distribuição de alimentos, quase a metade do retorno da Sadia se deu com o investimento em hedging cambial.

Mas os ganhos não duraram para sempre. Com o estouro da crise, a oscilação do dólar com relação ao real foi no caminho contrário do esperado pela Sadia e o prejuízo incorrido com o hedging foi gigantesco (cerca de 2,5 bilhões de reais, segundo o relatório da CVM).

A realização de operações envolvendo instrumentos financeiros cabia à diretoria financeira, liderada por Adriano Lima Ferreira (o diretor financeiro). Com o objetivo de controlar sua atuação no mercado financeiro, a Sadia possuía uma política financeira que limitava a tomada de riscos em operações dessa natureza em até $20 \%$ do patrimônio líquido da sociedade.

Em outras palavras, a companhia só poderia realizar operações financeiras se, quando somadas todas elas, o montante máximo que se esperasse poder perder fosse equivalente a, no máximo, $20 \%$ do seu patrimônio líquido. Essa porcentagem, de acordo com o voto do diretor relator Alexsandro Broedel Lopes, correspondia, em 2008, a R\$638.106.600,00.

Mas o valor das perdas possíveis com o investimento em derivativos cambiais ultrapassou em muito esse limite, chegando a $\mathrm{R} \$ 6.642 .667 .000,00$, ou 
seja, cerca de $80 \%$ do ativo total da Sadia ${ }^{437}$. Houve, portanto, extremo desrespeito ao estipulado pela política financeira da companhia. O diretor financeiro não poderia ter arriscado tamanho montante do patrimônio social com essas operações.

Em vista disso, os acionistas da Sadia, por meio do Poder Judiciário, ajuizaram contra o referido diretor uma ação social de reparação de danos. O mérito da ação, contudo, não chegou a ser analisado. O STJ, atento para o fato de que as demonstrações financeiras e as contas do administrador referentes ao exercício financeiro de 2008 tinham sido aprovas em assembleia geral ordinária, absolveu-o preliminarmente, com base no $\S 3^{\circ}$ do artigo 134 da Lei das S.A. ${ }^{438}$.

A CVM, por sua vez, instaurou o Processo Administrativo Sancionador $\mathrm{n}^{\mathrm{o}} 18 / 08$, que incluiu no rol de acusados, além do diretor financeiro, outros membros da administração da Sadia. Mas ressalve-se que, na medida em que o único administrador que realizou decisões negociais no sentido de investir em derivativos foi o diretor financeiro, a acusação e o julgamento da conduta dos demais administradores não serão aqui analisadas ${ }^{439}$.

No âmbito de tal processo, o diretor foi acusado por não ter empregado a diligência exigida para o exercício de seu cargo ao desrespeitar a política financeira da Sadia. Teria descumprido, assim, com o artigo 153 da Lei das S.A.

Em sua defesa, argumenta que a decisão por ter realizado as operações financeiras com derivativos deveria ser protegida pela business judgment rule,

\footnotetext{
${ }^{437}$ Processo Administrativo Sancionador CVM n ${ }^{\circ}$ 18/08, rel. Alexsandro Broedel Lopes, j. em 14 dez. 2010. É importante mencionar, aqui, que tamanho risco se deu em um cenário que não alcançou o limite máximo do teste de stress realizado (teste que leva em conta cenários extremos para antever a capacidade da companhia em resisti-los). Se tivesse alcançado esse limite, adverte o ex-diretor da CVM Alexsandro Broedel Lopes que o prejuízo seria ainda maior: "o prejuízo efetivamente sofrido pela companhia poderia ter sido ainda mais relevante, em valores comparáveis ao ativo total da companhia, caso o dólar alcançasse os patamares previstos para os testes de stress estabelecidos (...)".

438 “Art. 134. (...)

$\S 3^{\circ} \mathrm{A}$ aprovação, sem reserva, das demonstrações financeiras e das contas, exonera de responsabilidade os administradores e fiscais, salvo erro, dolo, fraude ou simulação (artigo 286)".

${ }^{439}$ A atuação dos outros administradores, membros do conselho de administração da Sadia, foi pautada pela falta de supervisão das operações dessa companhia. Assim, a análise mais adequada para a sua conduta seria não a business judgment rule, mas o padrão estabelecido no caso Caremark.
} 
uma vez que se tratava de uma decisão negocial. Segundo ele, os prejuízos teriam

sido causados pelo fato de que não se teria como antever a crise financeira.

De acordo com o relatório do processo administrativo, a defesa alegava

que

os riscos das operações [com derivativos] eram monitorados diariamente, por sofisticado sistema informatizado, implantado sob a liderança do acusado. $\mathrm{O}$ único cenário realmente não cogitado foi a eclosão da crise internacional, fato que não pode imputar responsabilidade apenas aos administradores da Sadia. Nesse sentido, ninguém se beneficiou indevidamente das operações, nem com elas visou a beneficiar terceiros, tendo o acusado agido de boa-fé, buscando o melhor interesse da companhia.

Assim, o acusado é pessoa qualificada para analisar, compreender e aplicar com eficiência o monitoramento adequado dos riscos inerentes a sofisticados instrumentos financeiros - só não está preparado para antever a crise da dimensão da que eclodiu em 2008, como também não estavam todas as autoridades financeiras e reguladores do mercado de todos os países do mundo. Por essa razão que os próprios acionistas, controladores e minoritários, deram a todos administradores da Sadia, incluindo o acusado, a quitação, ao aprovarem, nos termos do artigo 134 da Lei $n^{\circ}$ 6.404/76, as demonstrações financeiras de $2008^{440}$.

Mas, de acordo com o diretor relator, a business judgment rule não é aplicável ao caso concreto. Isso porque o que está em tela não é se a decisão em realizar operações complexas com derivativos foi correta. O que se analisa, na verdade, é se a política financeira da Sadia foi devidamente respeitada por seus administradores.

Assim versa o seu voto:

Esclareça-se que não está se falando do julgamento negocial dos administradores acerca do nível adequado de risco e retorno que a companhia deve se expor. Essa é uma decisão gerencial que não deve ser questionada por esta autarquia.

Nesse ponto, abro um parêntese para debater, desde já, o argumento de defesa que levantou a utilização do chamado "business judgement rule", pelo qual os atos realizados pelo administrador na regular gestão da companhia, segundo o seu julgamento de conveniência e oportunidade, não podem ser atacados se os seus efeitos se mostraram danosos. Esse argumento de defesa está correto. Porém, não se aplica ao presente caso, tendo em vista que: (i) não está em discussão a decisão da Sadia em realizar operações complexas, com derivativos; (ii) não estão em discussão, tampouco, os prejuízos gerados por essas operações. Como se desenvolverá no decorrer desse voto, estamos discutindo, tão somente, a diligência dos seus administradores na adoção

440 Processo Administrativo Sancionador CVM n ${ }^{\circ}$ 18/08, rel. Alexsandro Broedel Lopes, j. em 14 dez. 2010 . 
e monitoração dos sistemas de controles, que serviam para a verificação do cumprimento das políticas internas implantadas na própria Sadia ${ }^{441}$.

E, no final do voto, conclui afirmando que a responsabilização do diretor se dá não pela realização das operações financeiras, mas, sim, pelo desrespeito à política financeira da companhia:

(...) o próprio Diretor Financeiro reconhece que essa decisão, de manter ou reverter as posições, reveste-se do "business judgement rule", razão pela qual a CVM não poderia manifestar-se sobre o seu mérito. Concordo com esse argumento, como disse anteriormente. $\mathrm{O}$ que não concordo, contudo, que esses acontecimentos, relativos a fatos mais próximos da eclosão da crise internacional, demonstrem a diligência do Diretor Financeiro. O que demonstraria a sua diligência seria a utilização correta dos instrumentos de hedge, que servem justamente para criar uma proteção para companhia sobre eventos incertos. Isso pode soar óbvio. Porém, em situações como essa, nota-se que essa importante faceta dos derivativos, de realização de hedge para a companhia, é por vezes negligenciada por aqueles que mais precisam de proteção. Volto a afirmar que não estou avaliando a propriedade da realização de tais operações, mas somente sua adequação às políticas de risco estabelecidas pela própria companhia ${ }^{442}$.

No mesmo sentido votou o diretor Otavio Yazbek:

(...) o problema não está nas decisões negociais, sujeitas ao business judgment rule, tantas vezes prestigiado pela autarquia, tampouco na organização da gestão da companhia em sentido mais amplo, mas sim no fato de que os administradores deixaram de lado, sem maiores salvaguardas, obrigações que, no caso, claramente lhes incumbiam ${ }^{443}$.

Assim, o Colegiado da CVM, em face da atuação não diligente do diretor financeiro da Sadia, não aplicou a business judgment rule e, por maioria, condenou-o à pena de inabilitação temporária por três anos para o exercício de cargo de administrador de companhia aberta ${ }^{444}$.

\subsubsection{O Caso Citigroup}

Nos Estados Unidos, a aplicação da business judgment rule na crise financeira se deu de forma um pouco diferente daquela que se viu no Brasil. Ao

\footnotetext{
${ }^{441}$ Processo Administrativo Sancionador CVM no 18/08, rel. Alexsandro Broedel Lopes, j. em 14 dez. 2010.

${ }^{442}$ Processo Administrativo Sancionador CVM nº 18/08, rel. Alexsandro Broedel Lopes, j. em 14 dez. 2010.

${ }^{443}$ Processo Administrativo Sancionador CVM no 18/08, rel. Alexsandro Broedel Lopes, j. em 14 dez. 2010.

${ }^{444} \mathrm{O}$ diretor Eli Loria divergiu dos demais quanto à dosimetria da pena. Para ele, o diretor financeiro deveria ser condenado à pena de inabilitação por cinco anos para o exercício de cargo de administrador de companhia aberta.
} 
passo em que, aqui, companhias que estavam sujeitas à oscilação do dólar sofreram imensos prejuízos porque seus administradores não observaram suas políticas financeiras, lá, os administradores de bancos comerciais foram atacados por terem decidido investir em créditos subprime.

Como se verá, a análise se dá por outro ângulo.

O caso In Re Citigroup Inc. Shareholder Derivative Litigation, julgado pela Corte de Chancelaria de Delaware em fevereiro de $2009^{445}$, ilustra bem a aplicação da business judgment rule pelos tribunais norte-americanos em ações judiciais decorrentes das perdas com a crise. Nesse caso, os acionistas do Citigroup Inc. buscavam a responsabilização pessoal dos administradores dessa companhia por danos causados pela exposição ao mercado de empréstimos subprime.

Basicamente, de acordo com eles, os administradores teriam descumprido seus deveres de monitoramento por terem deixado que o Citigroup incorresse em grandes riscos e prejuízos de aproximadamente 55 bilhões de dólares com investimentos em subprime. Em outras palavras, os autores alegam que os réus não poderiam ter exercido um juízo negocial válido porque não teriam supervisionado os riscos aos quais o Citigroup estava sujeito por conta dos referidos investimentos.

Nesse sentido, apontam que os administradores teriam ignorado red flags relativas a problemas do mercado imobiliário e de crédito (ou seja, extrínsecas às atividades do Citigroup), como, por exemplo, a opinião do economista Paul Krugman, de que o mercado imobiliário norte-americano estaria chegando ao seu final, e o fato de que diversas instituições que investiam em subprime foram à falência.

Ao analisar os argumentos dos autores, a Corte indicou e distinguiu duas hipóteses de responsabilização de administradores de sociedades anônimas. A

${ }^{445}$ In Re Citigroup Inc. Shareholder Derivative Litigation, 964 A.2d 106 (2009). 
primeira seria o caso de uma decisão negocial que resulta em danos à companhia por ter sido má informada ou negligente. A segunda, uma falha do administrador em atuar em circunstâncias nas quais a sua atuação poderia prevenir os danos sofridos.

$\mathrm{Na}$ primeira hipótese, a business judgment rule seria aplicada para analisar a conduta do administrador, ao passo que, na segunda, o padrão estabelecido no caso Caremark seria o mais adequado.

Em tal caso, os autores alegaram que os administradores deveriam ser responsabilizados porque deveriam saber que determinados diretores e empregados da companhia estavam violando certa lei do ordenamento norteamericano. A decisão determinou duas situações que ensejam a responsabilização dos administradores por descumprimento ao dever de monitoramento: (i) a ocorrência de uma falha consciente em implementar sistemas ou controles de reportes e informações; ou, (ii) implementados esses sistemas ou controles, falha consciente em monitorar as operações de tais sistemas ou controles.

Sendo assim, verifica-se que as alegações dos autores no caso Citigroup não dizem respeito a um descumprimento ao dever de monitoramento. $\mathrm{Na}$ verdade, elas se referem à falha dos administradores em supervisionar o risco inerente a um negócio da companhia. E, para comprovar tal falha, apontaram as red flags acima mencionadas, que diziam respeito apenas ao declínio do mercado em que o investimento realizado estava inserido.

Nesse sentido constatou a Corte de Chancelaria de Delaware:

Where one looks past the lofty allegations of duties of oversight and red flags used to dress up these claims, what is left appears to be plaintiff shareholders attempting to hold the director defendants personally liable for making (or allowing to be made) business decisions that, in hindsight, turned out poorly for the Company ${ }^{446}$.

${ }^{446}$ In Re Citigroup Inc. Shareholder Derivative Litigation, 964 A.2d 106 (2009). 
Trata-se, assim, de um caso referente à decisão dos administradores em continuar ou não a investir em títulos cujos riscos eram cada vez maiores. Nesse contexto, para que sejam responsabilizados ou não, sua conduta deve ser analisada à luz da business judgment rule. É o que conclui o Tribunal:

To recognize such claims under a theory of director oversight liability would undermine the long established protections of the business judgment rule. It is well established that the mere fact that a company takes on business risk and suffers losses-even catastrophic losses-does not evidence misconduct, and without more, is not a basis for personal director liability. That there were signs in the market that reflected worsening conditions and suggested that conditions may deteriorate even further is not an invitation for this Court to disregard the presumptions of the business judgment rule and conclude that the directors are liable because they did not properly evaluate business risk ${ }^{447}$.

Conclui-se que, na verdade, os acionistas desejavam intervir em uma decisão negocial dos administradores do Citigroup por eles considerada como errada:

What plaintiffs are asking the Court to conclude from the presence of these "red flags" is that the directors failed to see the extent of Citigroup's business risk and therefore made a "wrong" business decision by allowing Citigroup to be exposed to the subprime mortgage market ${ }^{448}$.

Nesse caso, impor aos administradores responsabilidade por não terem supervisionado o risco de um negócio faria com que o Poder Judiciário interviesse em decisões negociais que simplesmente acreditaram valer tomar o risco (ao invés de evitá-lo quando percebido).

Mostrou a Corte, então, que a aplicação da business judgment rule deve prevalecer mesmo em momentos de profunda crise econômica, como foi a dos subprime. É natural, nesses momentos, que os prejudicados procurem um culpado para tamanhos prejuízos. E o primeiro alvo costuma ser o administrador, a pessoa que estava à frente dos negócios.

Contudo, deve-se ter em mente que, em uma economia de mercado, crises financeiras são comuns. O mercado, de maneira imprevisível, pode dar

${ }^{447}$ In Re Citigroup Inc. Shareholder Derivative Litigation, 964 A.2d 106 (2009).
${ }^{448}$ In Re Citigroup Inc. Shareholder Derivative Litigation, 964 A.2d 106 (2009). 
reviravoltas que transformam investimentos uma vez promissores em desastres econômicos que levam grandes companhias à falência.

Por isso, atribuir responsabilidade aos administradores por não terem antevisto uma crise na economia causaria outra crise: profissionais competentes não aceitariam administrar uma sociedade empresária; os riscos de tal atividade seriam enormes. 


\section{CONCLUSÃO}

Como se pôde ver ao longo desta monografia, a atividade de administração de companhias está intimamente ligada à tomada de riscos. Uma vez que o principal objetivo de uma sociedade anônima é a distribuição de lucros aos seus acionistas, conselheiros e diretores não podem se resguardar de tomar decisões arriscadas.

O lucro só é possível em um cenário em que mudanças sejam recorrentes e imprevisíveis. Como visto, se não houvesse mudanças constantes na economia, o mercado chegaria ao seu ponto ideal, em que os custos se igualariam aos preços; e se as mudanças fossem previsíveis, o futuro já seria conhecido no presente e as diferenças entre custos e preços já seriam antecipadamente neutralizadas.

Assim, toda decisão negocial que visa ao lucro necessariamente abarca algum grau de risco ou incerteza, confirmando-se, portanto, a máxima de que, sem risco, não há lucro.

Além disso, como se viu pela análise da Teoria dos Jogos, em um mercado competitivo, os resultados das decisões negociais são fortemente influenciados pelo comportamento de competidores, que podem frustrar qualquer planejamento econômico. Pelo estudo do dilema do prisioneiro e o equilíbrio de Nash, demonstrou-se que os resultados das decisões dos administradores estão condicionados a diversos fatores inerentes à existência de um concorrente ativo no mercado, cujo movimento pode fazer com que uma decisão bem calculada possa ser drasticamente derrubada ou abatida.

Dessa forma, conclui-se que a tomada de decisão dos administradores está envolta de dificuldades advindas do próprio mercado e de seus concorrentes. Seria injusto, assim, considerá-los culpados por prejuízos sofridos por conta de fatores que estão fora de seu alcance. 
Em resumo, sem conhecer o futuro e nem antever os passos de seus concorrentes, esses profissionais têm a árdua tarefa de auferir lucros e distribuilos entre os acionistas, que, se insatisfeitos, podem destitui-los de seus cargos e substitui-los a qualquer momento.

Contrapondo-se a estrutura da administração de companhias e a prática da tomada de decisão ao regime de responsabilidade dos administradores, foi possível analisar se este encontra-se adequado à realidade fática. Trata-se, aqui, do estudo da relação entre a norma jurídica e o fato social por ela regulado.

A primeira conclusão que se pode tirar a esse respeito é a de que o mencionado regime de responsabilidade deve ser criterioso. Levando em conta o fenômeno da cisão entre a propriedade e a gestão de uma sociedade anônima, o ordenamento jurídico deve garantir, ao mesmo tempo, que não haja abusos cometidos por administradores e que a ousadia destes não seja limitada pelo medo de poderem ser responsabilizados por qualquer erro negocial.

Merece destaque, aqui, o acerto do legislador brasileiro em instituir a obrigação dos administradores como de meio, pautada pelo padrão exigido no artigo 153 da Lei das S.A., que impõe a diretores e conselheiros a observância do dever de diligência.

A segunda conclusão consiste no fato de que a business judgment rule cai como uma luva para alcançar esse equilíbrio. Ao vedar a revisão, por parte do Poder Judiciário (e da CVM, como órgão regulador), de decisões negociais tomadas diligentemente, de boa-fé e no interesse da companhia, a regra protege administradores honestos que, por conta da imprevisibilidade do futuro e da atuação de concorrentes no mercado competitivo, trouxeram prejuízos à companhia.

Assim, é evidente a virtude dos tribunais norte-americanos ao elaborarem a regra em questão, reconhecendo que a tomada de decisão não é algo simples e que mesmo aqueles mais diligentes e honestos podem cometer erros. 
Outro ponto que se deve destacar é o de que, como visto com a leitura conjunta dos Capítulos 3, 4 e 5 desta monografia, a business judgment rule é plenamente compatível com o direito brasileiro, na medida em que o caput do artigo 158 da Lei das S.A. dispõe que os administradores não serão responsabilizados pela prática de atos regulares de gestão.

Ao abarcar todos os elementos da regra norte-americana, o instituto do ato regular de gestão mostra-se como o responsável pela recepção da business judgment rule no direito brasileiro.

Não obstante, sua aplicação já é consolidada na CVM. Diante da análise dos casos julgados de 2000 a maio de 2014, pôde-se perceber que a autarquia, muitas vezes com base nos aspectos do dever de diligência ou no próprio conceito do ato regular de gestão, já aplica os princípios da business judgment rule em suas decisões, absolvendo aqueles administradores que cometeram erros negociais de maneira honesta e diligente.

O mesmo, contudo, não ocorre com os julgamentos realizados pelo Poder Judiciário. Como se viu pelas decisões proferidas na Apelação Cível no 7.460/04 e no Processo $n^{\circ}$ 2003.001.047338-0, os juízes se mostraram incapazes de reconhecer um erro negocial legítimo dos administradores réus. Por conta disso, entraram no mérito das decisões tomadas, chegando ao absurdo de se afirmar que a má-fé poderia ser presumida por um mau investimento.

A deficiência do Judiciário brasileiro em analisar matérias relacionadas ao Law \& Economics se mostra ainda mais evidente no julgamento do Processo $\mathrm{n}^{\mathrm{o}}$ 2003.001.047338-0, uma vez que exatamente o mesmo caso foi julgado também pela CVM no âmbito administrativo. Enquanto esta autarquia aplicou corretamente a business judgment rule e absolveu os acusados, o juiz de direito os condenou ao pagamento do valor total de $\mathrm{R} \$ 1.931 .277,40$ por não ter sido a decisão negocial vantajosa para as companhias envolvidas. 
Decisões como essas causam insegurança jurídica e inibem a tomada de riscos por parte de administradores. Não obstante todas as dificuldades oriundas do mercado em si, a repressão dos tribunais à tomada de riscos afasta pessoas competentes e honestas da administração de empresas. E o resultado disso é a permanência de aventureiros, que, como coloca ADAMEK, trariam consigo ineficiência e irresponsabilidade na condução de negócios ${ }^{449}$.

Deve-se, portanto, evitar a responsabilização pessoal de administradores por decisões que observarem os elementos da business judgment rule. Afinal, nas palavras da diretora da CVM Ana Dolores de Novaes, "é muito fácil apontar que uma decisão foi errada olhando pelo retrovisor do tempo" ${ }^{450}$.

\footnotetext{
${ }^{449}$ ADAMEK, Marcelo Vieira von. Responsabilidade Civil dos Administradores de S/A e as ações correlatas. São Paulo: Saraiva, 2009. p. 194.

450 Processo Administrativo Sancionador CVM no RJ2008/9574, Rel. Ana Dolores Moura Carneiro de Novaes, j. em 27 nov. 2012.
} 


\section{BIBLIOGRAFIA}

ABRAMCZUK, André A. A Prática da Tomada de Decisão. São Paulo: Atlas, 2009. $150 \mathrm{p}$.

ABREU, Jorge Manuel Coutinho de. Curso de Direito Comercial, Sociedades. Coimbra: Almedina, 2003. 449 p.

ADAMEK, Marcelo Vieira von. Ação Individual Contra Administrador de Companhia Para o Fim de Obter a Reparação de Dano Individual Reflexo ou Indireto (LSA, Art. 159, $\S 7^{\circ}$ ): Descabimento. Revista de Direito Mercantil, Industrial, Econômico e Financeiro. vol. 142. abr./jun. 2006. p. 248-255.

ADAMEK, Marcelo Vieira von. Responsabilidade Civil dos Administradores de S/A e as ações correlatas. São Paulo: Saraiva, 2009. 617 p.

ALLEN, William T.; JACOBS, Jack B.; STRINE, Leo E. Function Over Form: A Reassessment of Standards of Review in Delaware Corporation Law. The Business Lawyer. v. 56, ago. 2001. p. 1287-1321.

ALLEN, William T.; JACOBS, Jack B.; STRINE, Leo E. Realigning the Standard of Review of Director Due Care with Delaware Public Policy: a Critique of Van Gorkom and Its Progeny as a Standard of Review Problem. Northwestern University Law Review. vol. 96, n² 2, 2001-2002. p. 449-466.

AMAN, Todd M. Cost-Benefit Analysis of the Business Judgment Rule: a Critique in Light of the Financial Meltdown. Albany Law Review. vol. 74, 20102011.p. 1-45.

ARAGÃO, Paulo Cesar. A disciplina do acordo de acionistas na reforma da lei das sociedades por ações: Lei $\mathrm{n}^{\circ}$ 10.303/2001. In: LOBO, Jorge (Org.) Reforma 
da lei das sociedades anônimas: Inovações e Questões Controvertidas da Lei $\mathrm{n}^{\circ}$ 10.303, de 31.10.2001. Rio de Janeiro: Forense, 2002. p. 367-384.

AZEVEDO, Antônio Ivanir de. Responsabilidade Civil do Administrador. Revista dos Tribunais. v. 653, mar. 1990. p. 78-84.

BAINBRIDGE, Stephen M. The Business Judgment Rule as Abstention Doctrine. Vanderbilt Law Review. vol. 57. nº 1. p. 83-130.

BERLE, Adolf A.; MEANS, Gardiner C. The Modern Corporation \& Private Property. New Brunswick: Transaction Publishers, 2009. 380 p.

BÊRNI, Duílio de Ávila. Teoria dos Jogos. São Paulo: Reichmann \& Affonso Editores, 2004. 138 p.

BINMORE, Ken. Rational Decisions. Princeton: Princeton University Press, 2009. $200 \mathrm{p}$.

BLACK, Bernard S. The Core Fiduciary Duties of Outside Directors. Asia Business Law Review, n 3-16, jul. 2001. 35 p.

BLOCK, Dennis J.; BARTON, Nancy E.; RADIN, Stephen A. The Business Judgment Rule: Fiduciary Duties of Corporate Directors. $6^{\text {a }}$ ed. Nova York: Aspen Publishers, 2009. vol. I. 1408 p.

BLOK, Marcella. Business Judgment Rule: a responsabilidade dos administradores das sociedades anônimas. Revista de Direito Bancário e do Mercado de Capitais. vol. 46, out. 2009. p. 129-162.

BORBA, José Edwaldo Tavares. Direito societário. $8^{\mathrm{a}}$ ed. Rio de Janeiro: Renovar, 2003. 576 p. 
BRADLEY, Michael; SCHIPANI, Cindy A. The Relevance of the Duty of Care Standard in Corporate Governance. Iowa Law Review. vol. 75, nº 1, 1989-1990, $74 \mathrm{p}$.

BRANSON, Douglas M. The Rule that Isn't a Rule - The Business Judgment Rule. Valparaiso University Law Review, n. 3, 2002, vol. 36, p. 631-654.

BRIGAGÃO, Pedro Henrique Castello; DA COSTA, Gabriel Carvalho; FERNANDES, Renata; FRANÇA, Luiz Felipe; PRATES, Nathalia; VIEIRA, Victor. O Dever de Diligência dos Administradores de Sociedade Anônima. Relatório Anual PIBIC 2012. Pontifícia Universidade Católica do Rio de Janeiro - PUC-Rio. 26 p.

BULGARELLI, Waldirio. Apontamentos Sobre a Responsabilidade dos Administradores das Companhias. Revista de Direito Mercantil, Industrial, Econômico e Financeiro. vol. 50. abr./jun. 1983. p. 75-105.

BULGARELLI, Waldirio. Manual das Sociedades Anônimas. 6 ed. São Paulo: Atlas, 1991. 343 p.

CAMPINHO, Sérgio. O Direito de Empresa à Luz do Novo Código Civil. 11 ${ }^{\mathrm{a}}$ ed. Rio de Janeiro: Renovar, 2010. 399 p.

CAMPOS, Luiz Antonio de Sampaio. Deveres e Responsabilidades. In: LAMY FILHO, Alfredo; PEDREIRA, José Luiz Bulhões (Org.). Direito das Companhias. Rio de Janeiro: Forense, 2009.

CARVALHOSA, Modesto. Comentários à Lei de Sociedades Anônimas. $4^{\mathrm{a}}$ ed. vol. 3. São Paulo: Saraiva, 2009. 885 p.

CARVAlHOSA, Modesto. Responsabilidade Civil dos Administradores das Companhias Abertas. Revista de Direito Mercantil, Industrial, Econômico e Financeiro. São Paulo, n. 49, jan./mar. 1983. p. 13-20. 
CASTRO NEVES, José Roberto de. Direito das Obrigações. 2a ed. Rio de Janeiro: GZ Ed., 2009. 434 p.

CINTRA, Antonio Carlos Fontes. Responsabilidade dos administradores perante a má fortuna do negócio e a business judgment rule. Revista de Direito Bancário e do Mercado de Capitais. vol. 58, out. 2012. p. 51-70.

COELHO, Fábio Ulhoa. A natureza subjetiva da responsabilidade civil dos administradores de companhia. Revista Direito de Empresa. vol. 1. p. 9-38.

COMPARATO, Fábio Konder. O Poder de Controle na Sociedade Anônima. $3^{\mathrm{a}}$ ed. Rio de Janeiro: Forense, 1983. 408 p.

CORRÊA LIMA, Osmar Brina. Regra de Julgamento de Negócios ("Business Judgment Rule”). In: SILVA, Alexandre Couto (Org.). Direito Societário: estudos sobre a Lei de Sociedades por Ações. São Paulo: Saraiva, 2013. p. 153 169.

CORRÊA LIMA, Osmar Brina. Responsabilidade Civil dos Administradores de Sociedades Anônimas. Rio de Janeiro: Aide Ed., 1989. 160 p.

CUNHA PEIXOTO, Carlos Fulgêncio da. Sociedade por Ações. vol. 4. São Paulo: Saraiva, 1973. 416 p.

CUNHA, Rodrigo Ferraz Pimenta da. Estrutura de Interesses nas Sociedades Anônimas: hierarquia e conflitos. São Paulo: Quartier Latin, 2007. 352 p.

DIXIT, Avinash; NALEBUFF, Barry. Prisoners' Dilemma. Fortune Encyclopedia of Economics. Nova York: Warner Books. p. 61-63.

DOOLEY, Michael P.; VEASEY, E. Norman. The Role of the Board in Derivative Litigation: Delaware Law and the Current ALI Proposals Compared. The Business Lawyer. v. 44, n² 2, fev. 1989. p. 503-542. 
DRUCKER, Peter F. Innovation and Entrepreneurship. Nova York: Harper, 1985. $277 \mathrm{p}$.

DRUCKER, Peter F. The Discipline of Innovation. In: HBR's Ten Must Reads on Innovation. Boston: Harvard Business Review Press, 2013. p. 143-156.

EISENBERG, Melvin Aron. The Divergence of Standards of Conduct and Standards of Review in Corporate Law. Fordham Law Review. vol. 62, 1993, p. 437-468.

EIZIRIK, Nelson; GRAAL, Ariádna B.; PARENTE, Flávia; HENRIQUES, Marcus de Freitas. Mercado de Capitais: Regime Jurídico. $3^{\text {a }}$ ed. Rio de Janeiro: Renovar, 2011. 660 p.

EIZIRIK, Nelson. A Lei das S/A Comentada. vol. 2. São Paulo: Quartier Latin, $2011.662 \mathrm{p}$.

EIZIRIK, Nelson. “Insider Trading” e Responsabilidade de Administrador de Companhia Aberta. Revista de Direito Mercantil, Industrial, Econômico e Financeiro. vol. 59. Abr./jun. 1983. p. 42-56.

EIZIRIK, Nelson. Temas de Direito Societário. Rio de Janeiro: Renovar, 2005, $630 \mathrm{p}$.

FIANI, Ronaldo. Teoria dos Jogos: com aplicações em economia, administração e ciências sociais. $3^{\mathrm{a}}$ ed. Rio de Janeiro: Elsevier, 1009. 394 p.

FINKELSTEIN, Sydney. Why Smart Executives Fail. Nova York: Portfolio, 2003. 319 p.

FRANÇA, Erasmo Valladão Azevedo e Novaes. Conflito de Interesses nas Assembleias de S.A. São Paulo: Malheiros, 1993.88 p. 
FRANÇA, Erasmo Valladão Azevedo e Novaes. Invalidade das Deliberações de Assembleia de S/A. São Paulo: Malheiros Editores, 1999. 152 p.

GOLDBERG, Mindy K. How Much Information is Enough. Journal of Law and Commerce, vol. 7, p. 225-242.

GOMES, Orlando. Responsabilidade dos Administradores de Sociedades por Ações. Revista de Direito Mercantil. São Paulo: nº 8, ano XI, 1972, p. 11-16.

GORDON, Jeffrey N. What Enron Means for the Management and Control of the Modern Business Corporation: Some Initial Reflections. The University of Chicago Law Review. v. 69, 2002. p. 1233-1250.

HANSEN, Charles. The Duty of Care, the Business Judgment Rule, and the American Law Institute Corporate Governance Project. Business Lawyer. v. 48, 1992-1993. p. 1355-1376.

IORIO DE SOUZA, Ubiratan Jorge. Economia e Liberdade: A Escola Austríaca e a Economia Brasileira. São Paulo: Editora Inconfidentes, 1995. 227 p.

KEYNES, John Maynard. The general theory of employment, interest and money. Londres: Macmillan, 1936. 168 p.

KEYNES, John Maynard. The General Theory of Employment. The Quarterly Journal of Economics. vol. 14. fev. 1937. p. 209-223.

KNIGHT, Frank H. Risk, uncertainty and profit. Londres: Houghton Mifflin, 1921. $381 \mathrm{p}$.

LAMY FILHO, Alfredo; PEDREIRA, José Luiz Bulhões. A Lei das S.A. Rio de Janeiro: Renovar, 1996. v. 2, 754 p. 
LAMY FILHO, Alfredo. Temas de S.A.: Exposições e Pareceres. Rio de Janeiro: Renovar, 2007. 452 p.

LAZZARESCHI NETO, Alfredo Sérgio. Efeitos da Aprovação das Contas e das Demonstrações Financeiras das Companhias. In: KUYVEN, Luiz Fernando Martins. Temas essenciais de direito empresarial: estudos em homenagem a Modesto Carvalhosa. São Paulo: Saraiva, 2012. p. 413-436.

LEÃES, Luiz Gastão Paes de Barros. Ação Social Derivada de Responsabilidade Civil dos Administradores. Revista de Direito Mercantil. vol. 112. out./dez. 1998. p. 127-135.

LEÃES, Luiz Gastão Paes de Barros. Sociedade por ações - atos praticados por seus diretores, em razão de administração - responsabilidade daquela e destes, solidariamente, se agiram com culpa ou contrariamente aos estatutos. Revista de Direito Mercantil, no 2, 1971. p. 74-82.

LEÃO JR., Luciano de Souza. Conselho de Administração e Diretoria: Administração da Companhia. In: LAMY FILHO, Alfredo; PEDREIRA, José Luiz Bulhões (Org.). Direito das Companhias. Rio de Janeiro: Forense, 2009. p. 1029-1068.

LOWENTHAL, Andrea. Corporate takeovers and the business judgment rule: the second circuit puts targets corporations on the auction block. Brooklyn Law Review. Nova York. v. 53. nº 2, summ. 1987. p. 409-441.

LUCENA, José Waldecy. Das sociedades anônimas: comentários à lei (arts. 121 a 188). vol. 2. Rio de Janeiro: Renovar, 2009. 1232 p.

LUCENA, José Waldecy. Das sociedades por quotas de responsabilidade limitada. Rio de Janeiro: Renovar, 1997. 866 p. 
MARIANI, Irineu. Responsabilidade Civil dos Sócios e dos Administradores de Sociedades Empresárias (à luz do Novo Código Civil). Disponível em <http://www.rkladvocacia.com/arquivos/artigos/art_srt_arquivo200807311256 26.pdf>. Acesso em 19 mar. 2013. 29 p.

MAXIMILIANO, Carlos. Hermenêutica e Aplicação do Direito. Rio de Janeiro: Forense, 1994. 335 p.

MCGRATH, Rita Gunter; MACMILLAN, Ian C. Discovery-Driven Planning. In: HBR's Ten Must Reads on Innovation. Boston: Harvard Business Review Press, 2013. p. 125-142.

MENEZES FILHO, Naercio; KANNEBLEY JUNIOR, Sérgio. Abertura Comercial, Exportações e Inovações no Brasil. In: VELOSO, Fernando; FERREIRA, Pedro Cavalcanti; GIAMBIAGI, Fabio; PESSÔA, Samuel (Org.). Desenvolvimento Econômico: uma Perspectiva Brasileira. Rio de Janeiro: Elsevier, 2013. p. 405-425.

MIRANDA, Pontes de. Tratado de Direito Privado. Parte Especial. Tomo L. $3^{\text {a }}$ ed. Rio de Janeiro: Editor Borsoi, 1972. 499 p.

MONTEIRO GOMES, Luiz Flavio Autran; SIMÕES GOMES, Carlos Francisco. Tomada de Decisão Gerencial: Enfoque Multicritério. $4^{\circ}$ ed. São Paulo: Atlas, 2012. 331 p.

NASCIMENTO, João Pedro Barroso do. Medidas Defensivas à Tomada de Controle de Companhias. São Paulo: Quartier Latin, 2011. 285 p.

NASCIMENTO, João Pedro Barroso do. Regra do Julgamento do Negócio (Business Judgment Rule). In: SILVA, Alexandre Couto (Org.). Direito Societário: estudos sobre a Lei de Sociedades por Ações. São Paulo: Saraiva, 2013. p. 171-178. 
NASH, John. Non-Cooperative Games. The Annals of Mathematics. vol. 54. set. $1951, \mathrm{n}^{\circ} 2$. p. $286-295$.

NOVAES, Ana. Derivativos e Governança Corporativa: O Caso Sadia Corrigindo o Que Não Funcionou. Disponível em <http://www.economia.pucrio.br/mgarcia/Seminario/textos_preliminares/101705\%20Derivativos\%20e\%2 0Governan\%C3\%A7a\%20Corporativa.pdf>. Acesso em 5 nov. 2013.

PARENTE, Flávia. O Dever de Diligência dos Administradores de Sociedades Anônimas. Rio de Janeiro: Renovar, 2005. 260 p.

PARENTE, Norma Jonssen. Limites da Responsabilidade dos Administradores pela Indenização de Prejuízos. Revista de Direito Bancário e do Mercado de Capitais. vol. 31. jan. 2006. p. 33-37.

PEDREIRA, José Bulhões; ROSMAN, Luiz Alberto Colonna. Aprovação das Demonstrações Financeiras, Tomada de Contas dos Administradores e seus Efeitos. Necessidade de Prévia Anulação da Deliberação que Aprovou as Contas dos Administradores para Propositura de Ação de Responsabilidade. In: CASTRO, Rodrigo R. Monteiro de; ARAGÃO, Leandro Santos de (Org.). Sociedade Anônima: 30 anos da Lei 6.404/76. São Paulo: Quartier Latin, 2007. p. 41-63.

PEDREIRA, José Luiz Bulhões; LAMY FILHO, Alfredo. Estrutura da Companhia. In: LAMY FILHO, Alfredo; PEDREIRA, José Luiz Bulhões (Org.). Direito das Companhias. Rio de Janeiro: Forense, 2009. p. 775-870.

PEREIRA, Caio Mário da Silva. Responsabilidade Civil. 10ª ed. Rio de Janeiro: GZ Ed., 2012. 462 p.

PINHEIRO, Armando Castelar; SADDI, Jairo. Direito, Economia e Mercados. Rio de Janeiro: Elsevier, 2005. 553 p. 
POUNDSTONE, William. Prisoner's Dilemma. Nova York: Anchor, 1993. 294 p.

Principles of Corporate Governance: Analysis and Recommendations, §4.01(c), 1994.

REALE, Miguel. A Boa-fé no Código Civil. Disponível em <http://www.miguelreale.com.br/artigos/boafe.htm>. Acesso em 22 mar. 2014.

REQUIÃO, Rubens. O Controle e a Proteção dos Acionistas. In: WALD, Arnoldo (Coord.). Doutrinas Essenciais de Direito Empresarial. vol. 3. Rio de Janeiro: Revista dos Tribunais, 2009. p. 23-36.

Revised Model Business Corporate Act. Comentário Oficial à Seção 8.30.

Revised Model Business Corporate Act. Comentário Oficial à Seção 8.31.

RIBEIRO, Júlio Cesar de Lima. A transposição da business judgment rule para o regime da responsabilidade civil de administradores em Portugal e no Brasil. Revista dos Tribunais. vol. 937, nov. 2013, p. 391-416.

RIBEIRO, Renato Ventura. Dever de diligência dos administradores de sociedades. São Paulo: Quartier Latin, 2006. 287 p.

ROCHA, João Luiz Coelho da. Administradores, conselheiros e prepostos das sociedades. Rio de Janeiro: Lumen Juris, 2005, 186 p.

SILVA, Alexandre Couto. Responsabilidade dos Administradores de S/A: Business Judgment Rule. Rio de Janeiro: Elsevier, 2007. 264 p.

TAVARES GUERREIRO, José Alexandre. Propriedade Fiduciária das Ações. In: LOBO, Jorge (Org.). Reforma da Lei das Sociedades Anônimas: Inovações e 
Questões Controvertidas da Lei $\mathrm{n}^{\mathrm{o}}$ 10.303, de 31.10.2001. Rio de Janeiro: Forense, 2002. p. 51-59.

TAVARES GUERREIRO, José Alexandre. Responsabilidade dos Administradores de Sociedades Anônimas. Revista de Direito Mercantil, Industrial, Econômico e Financeiro. vol. 42. abr./jun. 1981. p. 69-88.

TEPEDINO, Ricardo. Assembleia Geral. In: LAMY FILHO, Alfredo; PEDREIRA, José Luiz Bulhões (Org.). Direito das Companhias. Rio de Janeiro: Forense, 2009. p. 871-1028.

TEIXEIRA, Egberto Lacerda; TAVARES GUERREIRO, José Alexandre. Das Sociedades Anônimas no Direito Brasileiro. São Paulo: Bushatsky, 1979. 885 p.

TORRES JUNIOR, Alvair Silveira; MOURA, Gilnei Luiz de. Decisão em Administração: uma discussão. In: YU, Abraham Sin Oih. Tomada de Decisão nas Organizações. São Paulo: Saraiva, 2011. p. 3-22.

TREBILCOCK, M. J. The Liability of Company Directors for Negligence. The Modern Law Review. vol. 32. set. 1969. nº 5. p. 499-515.

VALVERDE, Trajano de Miranda. Sociedade por Ações. $2^{\mathrm{a}}$ ed.. v. 2. Rio de Janeiro: Forense, 1953, 462 p.

VERÇOSA, Haroldo Malheiros Duclerc. Curso de Direito Comercial. vol. 2. São Paulo: Malheiros, 2006. 582 p.

VON NEUMANN, John; MORGENSTERN, Oskar. Theory of Games and Economic Behavior. Princeton: Princeton University Press, 1953. 665 p.

YAZBEK, Otávio. Representações do dever de diligência na doutrina jurídica brasileira: um exercício e alguns desafios. In: KUYVEN, Luiz Fernando Martins 
(Org.). Temas essenciais de direito empresarial: estudos em homenagem a Modesto Carvalhosa. São Paulo: Saraiva, 2012. p. 940-961.

ZAITZ, Daniela. Responsabilidade dos Administradores de Sociedades Anônimas e por Quotas de Responsabilidade Limitada. Revista dos Tribunais. São Paulo: Revista dos Tribunais, nº 740, jun. 1997, p. 11-52. 